
Digitized by the Internet Archive in 2007 with funding from Microsoft Corporation 




\section{THE MOOSE BOOK}

FACTS AND STORIES FROM

NORTHERN FORESTS

BY

SAMUEL MERRILL

ILLUSTRATED WITH REPRODUCTIONS OF PAINTINGS, DRAWINGS, AND P PHOTOGRAPHS

BY CARL RUNGIUS AND OTHERS

SECOND EDITION

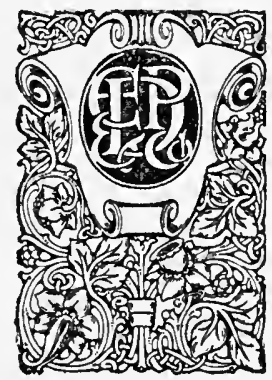

NEW YORK

E. P. DUTTON \& COMPANY

681 FIFTH AVENUE 
Copyright, igi 6 BY

E. P. DUTTON \& COMPANY

COPYRIGHT, I92O

BY

E. P. DUTTON \& COMPANY

Printed in the United States of America 


\section{PREFACE}

to the Second Edition

FOR this edition the portion of the second chapter in which facts are given relating to recent hunting seasons in various sections of the moose's range has been entirely rewritten (pages 43-52). In some cases, it will be observed, the latest returns are those for the season of I9I8. This is due to the inability of the game officials to make up their reports promptly, on account of delay in receiving reports from wardens and others. A new table of the game laws has been supplied, and other changes of less importance have been made in the electrotype plates.

Contrary to popular impression moose are much more than holding their own in the forests of North America. This is shown in an Appendix, where measures taken to extend the range of the moose are treated at some length, and where facts are given regarding the recent establishment of many game refuges to safeguard still further the future of our most highly prized biggame animal. In the Appendix also noteworthy 
trophies are described and illustrated, and in other ways effort is made to review all topics which concern the moose and his future.

The author is under obligation to many sportsmen and zoologists for their interest in the work, and for the assistance, in many cases unsolicited, which they have given by means of suggestions and data kindly furnished. The game officials of the States and Canadian Provinces which are included within the moose's range have, without exception, been prompt to contribute information. Especially is the author, and the reader in an equal degree, under obligation to Professor William F. Ganong of Northampton, to Hon. George Shiras, $3 \mathrm{~d}$, of Washington, to the late Dr. Charles Gordon Hewitt of Ottawa, to Mr. George L. Harrison, Jr., of Philadelphia, and to Henry J. Elwes, F.R.S., the English zoologist, for valuable facts and opinions on a number of pertinent topics.

Cambridge, Mass.

June I, 1920. 


\section{PREFACE}

to the First Edition

THE grand prize in the lottery of American sportsmanship is the moose. The domain of the giant deer stretches across the broad northland, from the Atlantic to the Pacific. In this territory thousands of moose are taken every year; to it tens of thousands of hunters go annually, in the cool autumn days, rifle in hand, seeking health and recreation, and hoping that they too may win the chief prize of the chase. Meanwhile no book has been published which has been devoted exclusively to the history of the moose, his habits and habitat, and the methods of hunting him.

Much of the material contained in these pages was gathered during the hunting trips of many years in the best moose country of Eastern America. The experiences and views of many guides and many sportsmen, told beside the fires of many camps, jotted down at the time in little vestpocket note-books, and sifted and verified by personal observation, have found their places 
here, together with the fruits of the author's own experience.

Published works in various languages in which facts relating to the moose and his European kinsman are to be found have been carefully studied, and by free use of footnotes, citing authorities in every branch of the subject, the reader is given the bibliography of the moose and moose hunting. Most quotations from ancient writers are from the first editions, and the extracts conform closely in the use of capitals and punctuation marks, as well as in spelling, to the originals. In the extracts from old French writers the accents to which modern readers are accustomed are in many cases lacking. This lack is due to typographical carelessness in the ancient printing shops and not to oversight on the part of the present printers.

American writers have generally ignored the elk of the Old World, albeit the moose and the European elk are practically of the same species, and indistinguishable. Most of the facts given in these pages regarding the moose's European and Asiatic congener have been hitherto unpublished in English.

The author wishes to acknowledge obligation to Mr. Carl Rungius, who has kindly consented 
to the use of reproductions of four of his paintings, and to the American Museum of Natural History, Mr. Julian A. Dimock, and others who have courteously permitted the use of their pictures in these pages.

Cambridge, Mass.

June $1,1916$. 



\section{CONTENTS}

PART I-THE AMERICAN MOOSE Chapter

I.--The Moose and His History . • 3

II.-American Range of the Moose - 32

III.-Traits and Habits of the Moose . 63

IV.-Still-Hunting $\quad$ • $\quad$ • $\quad$ • 999

V.-Calling the Moose • . . I 120

VI.-Miscellaneous Hunting Methods . 132

VII.-ARMS AND EQUipMent . . . I 152

VIII.-HEAds AND HoRns . . . . 166

IX.-Moose Meat as Food . . . 204

X.-The Future of the Moose . . 220

XI.-The Names of the Moose - . 232

XII.-The Moose in Indian Myth • . 245

PART II-THE OLD-WORLD ELK

XIII.-The Elk, Past and Present . . 27 I

XIV.-Range of the Elk in Europe and Asia 288

XV.-Traits and Habits of the Elk • 300

XVI.-How the Elk is Hunted . • 316 
XVII.-Antlers of the ElK . . . 334 XVIII.-Misbeliefs about the ElK . 346

\section{APPENDIX}

A.-Some Noteworthy Trophies . $\quad 357$

B.-Big-Game Refuges . . . . 36I

C.-Moose in Michigan . . . 365

D.-New Zealand's Moose Experiment . 367

E.-Stocking Newfoundland with Moose 370

F.-The Olympic National Forest . $37 \mathrm{I}$

G.-Moose in Pennsylvania . . . 372

H.-Vermont's Last Moose . . . 373

I.-Parasitic Enemies of the Moose . 374

J.-New Brunswick's Harnessed Moose 376

K.-Area Required for Maintenance of Moose . . . . . . . 377

L.-Jacking by Automobile Headlight . 379

M.-The Springfield Rifle in Big-Game Hunting . . . . . 380

N.-Mountain Ash in Antler-Building . 38 I

O.-European Elk in War-Time . . 384

P.-Fossil ElK in ENGland . . . 385

INDEX $\quad . \quad . \quad . \quad . \quad . \quad 387$ 


\section{ILLUSTRATIONS}

"Comrng to the CaLl"..................... Frontispiece

From a painting by Carl Rungius

PAGE

Lescarbot's Moose....................... 7

Antlers at About Five Years of Age............ 14

From a drawing by Carl Rungius

Game in New Netherland...................... 20

In the Heart of the Moose Country............ 25

From a photograph by the author

Michigan's Heraldic Moose................... 29

Range of the Moose in both Hemispheres (Map)...... 32

From a drawing by the author

Bull and Calf on the Upper Yellowstone.......... 38

From a photograph by Hon. George Shiras, 3d

Cow Moose, at Natural Salt Lick, Lake Superior...... 38

From a photograph by Hon. George Shiras, 3d

An Alaska Moose.....................

From a painting by Carl Rungius

An Alberta Bull............................. 45

One Hunting Party's Bag of Moose.............. 45

Fate of a Wroming Bull ............... 5 I

From a sketch by Carl Rungius

Mooseleur Mountarn, Maine, from Munsungan Lake.... 56

From a photograph by the author

A 55 -inch New Brunswick Head................ 65

From a photograph by Carl Rungius

AN UnReCORded Tragedy............................. 65

From a photograph by Carl Rungius 
Anti.ers at Three or Four Years of Age.

From a drawing by Carl Rungius

A Battle Between Bulls................... 8 I

From a painting by Carl Rungius

A Calf Moose.......................... 85

From a photograph by Julian A. Dimock

Bull Moose, St. Ignace Island, Ontario........... 86

The Calf When Five Months Old.............. 86

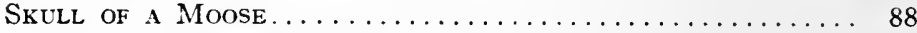

From a drawing by the author

November in the Moose Woods.................. 99

From a photograph by the author

Head of a Yukon Cow.

From a drawing by Carl Rungius

Hunting Against the Wind ................. I I I

Hunting With the Wind .................. I 2

Good Country for Calling................. 123

Before the Battle...................... I 30

From a painting by Carl Rungius

Crust Hunting in the Seventeenth Century.......... I 39

Bringing in a Good Specimen................ I 44

From a photograph by Carl Rungius

A Guide and a Trophy..................... I62

From a photograph by the author

Cast Antlers Found Near Kenai Lake............ I 7 I

From a photograph by Hon. George Shiras, 3d

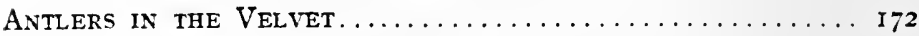

From a photograph by Carl Rungius

A Buli. in November...................... 174

From a drawing by Carl Rungius

The Record Spread $-78 \frac{1}{2}$ Inches................... I 177

From a photograph 
PAGE

The Reed-McMillan Antlers................ 178

From a photograph

The Niedieck Antlers..................... I 79

From a drawing by the author

From the Canadian Rockies................. I8I

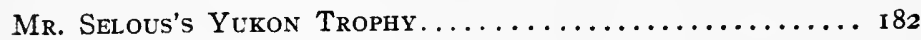

From a drawing by Carl Rungius

Cast Antlers Found in British Columbia........... I 83

A Former New Brunswick Record............... I84

Manitoba's Best Head...................... I 84

Minnesota's Best Head................... I84

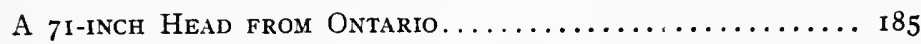

A New Record for New Brunswick............. 187

From a photograph

F. H. Cook's New Brunswick Moose-Head. . . . . . . . I 88

Measurement of Moose Antlers................ 190

A Head Cannot be Judged by Spread Alone........... 193

From a drawing by Carl Rungius

A Hungarian Design.................... 196

From a drawing by the author

A Moosehorn NApkin Ring................... 199

Dewclaw Bones of Moose................. 200

Trophies Brought to Camp................ 217

From a photograph by Carl Rungius

A Nova Scotia Prize....................... 222

From a photograph. Drawn by the author

A Remarkable Saskatchewan Head ............ 222

From a photograph. Drawn by the author

An Old Logging Camp........................... 232

A Logging Camp in the New Brunswick Woods......... 232 
The Moose in Politics................... 234

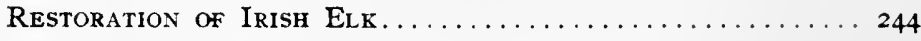

From a drawing by Charles R. Knight

A Vista in the Moose Country................... 257

From a photograph by Car! Rungius

Good Moose Cover......................... 257

Hunting Russian Elk...................... 271

From a painting by Richard Friese

An Elk Drive............................. 27 I

From a painting by $\mathrm{K}$. Wysotzki

An Asiatic Rock-Carving.......................... 273

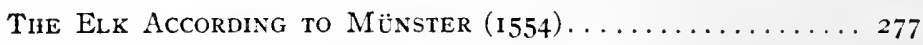

Aldrovandus's Female Elk $(1621) \ldots \ldots \ldots \ldots \ldots \ldots \ldots \ldots \ldots$

Head of Male Elk (Aldrovandus, 1621) ............. 279

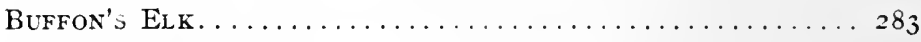

Si edge Drawn by Elk (Magnus, 1555) ............ 308

Brovght to Bay........................... $32 \mathrm{I}$

From a drawing by A. Erikson

A Scandinavian Poacher's Device................... 332

A Peculiar Siberian Type......................... 335

Fossil Antlers from Russian Poland............... 336

Best Elik Antlers at the Viensa Exhibition, $1910 \ldots \ldots \ldots 338$

An Eight-Year-Old from Livonia................... 340

Antlers of an Old Elk......................... $3 H^{I}$

Alces Bedfordia............................... 344

Elk Attacked by Epilepsy (Pomet, 1735)............ 349

Mr. Darrow's Quebec Trophy.......................... 359 
PAGE

Antlers of a Restigouche Veteran................. 359

Mount Katahdin, from Katahdin Lake............ 365

From a photograph by the author

Vermont's Last Moose......................... 374

Bullets Which Have Killed Moose.................. $3^{8 \mathrm{r}}$

Fossul Antlers Found in England.................... 385 

THE MOOSE BOOK 

Part I

\section{The American Moose}





\section{CHAPTER I}

\section{THE MOOSE AND HIS HISTORY}

In a plea for the preservation of the moose Professor Henry Fairfield Osborn, president of the New York Zoölogical Society, has said, "Nature has been a million years in developing that wonderful animal, and man should not ruthlessly destroy it!"

A million years! The imagination is helpless in attempting to grasp the idea of such a period of time, and the events which have taken place in it.

The ancestral home of the moose (Cerous alces) in prehistoric times was probably in Asia. Professor Osborn quotes Sir Victor Brooke as maintaining that the Cervida originated in Asia, and thence spread east and west. ${ }^{\mathrm{I}}$ But at just what stage in this little matter of a million years the first moose wandered into America over the land

The Age of Mammals in Europe, Asia, and North America (New York, 1910), p. 418. 
which then connected the two continents at Bering Strait, we shall never know. According to Professor William Berryman Scott of Princeton University the moose, the caribou, and the wapiti came from the Old World to the New not earlier than the Pleistocene. ${ }^{2}$ The moose seems to have preceded the caribou and the wapiti in the long migration. At any rate, the moose was present on the western half of the continent in the later Pleistocene, when the Glacial Era was drawing to a close. $^{3}$ The ancestors of the white-tailed or Virginia deer doubtless came from the same far-away Asiatic home, but in an earlier geologic age. How far south the moose ranged at that early day is not known, but his fossil remains are said to have been found south of the Ohio and Missouri rivers. ${ }^{4}$

'A Hi tory of Land Mammals in the Western Hemisphere (New York, I9I3), p. 4 I3.

3 Ibid., p. 202. Geologists variously estimate the period which has elapsed since the Pleistocene as from I00,000 to 200,000 years. Those of us who carry split-second watches will wonder at the inability of the geologists to measure time with more precision.

${ }_{4}$ Osborn, ubi supra, p. 449. Professor Osborn (pp. 47 1-472) mentions fossil bones of "Alces" as found in southern South Carolina. He cites as an authority Francis S. Holmes in the American Journal of Science, 1858, pp. 442-443, and in the Proceedings of the Academy of Natural Sciences, 1859, pp. 177-185. But Professor Holmes in his list names the "elk" as represented among the fossil re nains, meaning, no doubt, the American elk, or wapiti (Cervus canadensis), not the European elk, or moose (Cervus alces or Alces americanus). This is an instance of the confusion which has been entailed by the misnaming of the wapiti by the early settlers in America. Sce p. 237. 
It is impossible to say what European traveler in North America first encountered the moose. The earliest explorers on this continent were not sportsmen; they knew little about the deer of Europe, and were untrained as writers. As a result they have left us meager information relating to the characteristics or the numbers of the various species of deer which they found in their travels.

Jacques Cartier, who explored the valley of the St. Lawrence in 1535, and spent the winter there, mentions various wild beasts which the Indians hunted, including "dains" and "cerfz."s Hiram B. Stephens, B.C.L., translates dains by the word "moose," but expresses doubt of the identity of the animal. ${ }^{6}$ In several other places Cartier mentions "Cerfz छ Dains," and tells how he bought the meat of these animals from the Indians in the winter for his men, who were dying of scurvy, and were unable to hunt. As the Indian equivalents of these words he gives "Aiounesta 6 " Asquenoudo," but these words are not to be found in any of the Indian word-lists of other writers. There is little reason to doubt, however, that one

${ }^{5}$ Narration de la Navigation faite en MDXXXV et MDXXXVI par Le Capitaine Jacques Cartier aux Iles de Canada, Hochelaga, Saguenay et autres, fol. $3 \mathrm{I}$.

${ }^{6}$ Jacques Cartier and His Four Voyagesto Canada (Montreal, 1890), p. $7 \mathrm{r}$. 
or the other was the moose, for the great captain bought his winter store of meat from the Indians, and the Indians of that region depended largely on the moose for their own subsistence.

Champlain in 1603, and Lescarbot a year or two later, visited "New France," and both left valuable accounts of the country, its inhabitants and its fauna. Both explorers adopted the Basque word orenac when referring to the moose, and both seemed to recognize the animal as identical with the elk of Europe.

In The Savages, or Voyage of Sieur de Champlain made in the Year 1603, Champlain mentions "orignacs" first in a list of twelve species of animals on which the savages of the St. Lawrence Valley subsisted. A year later, telling of his exploration of the St. Croix River, he describes the winter hunting of the aborigines. On snowshoes, with "filling" of moose hide, dressed in skins of beaver and moose, men, women, and children, armed with bows and spears, would take the trail into the moose country, in quest of their winter's store of food. ${ }^{7}$

Marc Lescarbot of Paris, historian of New

7 "Durant l'hyver au fort des neges ils vont chasser aux eslans, \& autres bestes, dequoy ils vivent la plus-part du temps." -Les Voyages de la Nouvelle France Occidentale, dicte Canada (Paris, 1632), p. 71. Les Voyages du Sieur de Champlain (Paris, 1613), pp. 56-57. 
France, lawyer, poet, and Huguenot sympathiser, spent some time with de Monts' colony in Acadia.

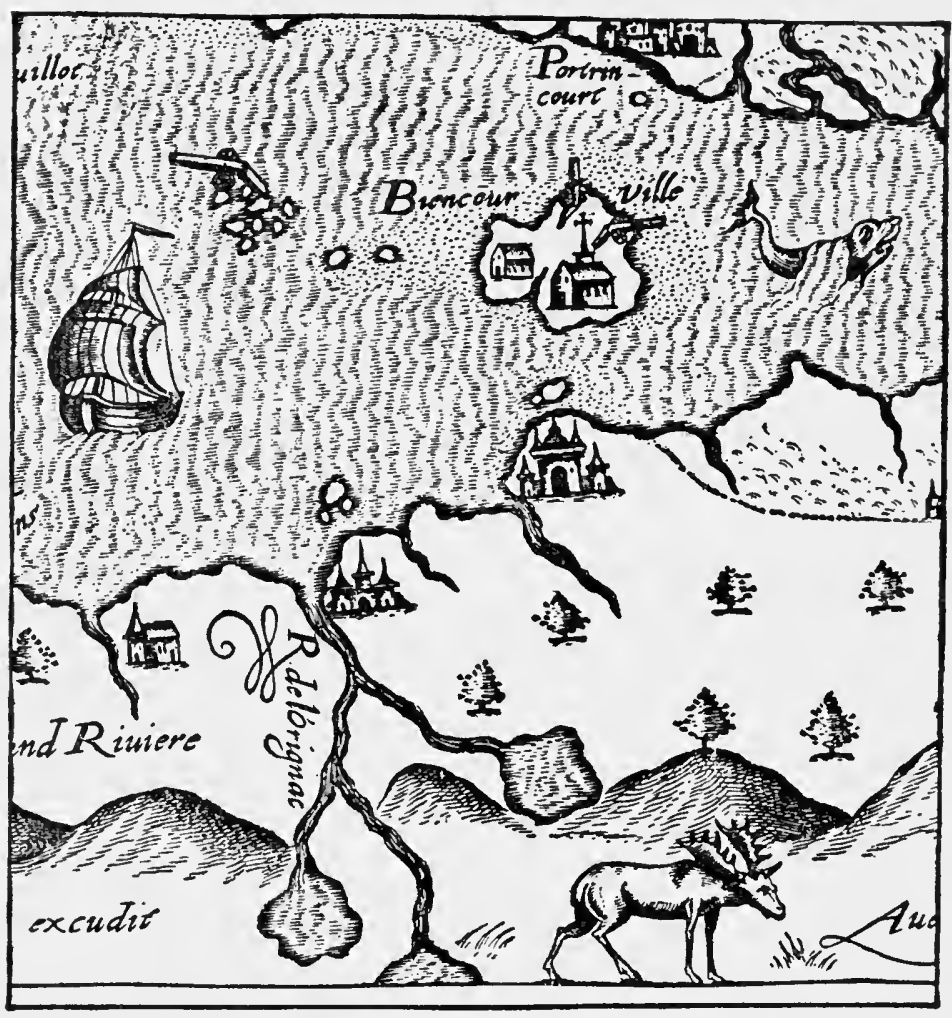

Lescarbot's Moose

On his map of Port Royal (Annapolis Basin, Nova Scotia), he shows "R[ivière] de l'Orignac." This is represented on recent maps under the name of Moose River. It is a short and insignificant stream when the tide is out, but twice a day, 
thanks to the extraordinary tidal action in the Bay of Fundy, it is capable of floating vessels of considerable size. Indeed, shipbuilding on a respectable scale has been carried on along its banks.

This map is entitled "Figure du Port Royal en la Nouvelle France, par Marc Lescarbot, I600." On its lower margin, close to the river which was named in its honor, stands a moose. This is probably the earliest picture of the American moose which has come down to us.

"First let us speak of the elk," writes Lescarbot, "which they [the Indians] call Aptaptou, and our Basques Orignac. . . . It is the most abundant food which the savages have, except fish."8

Lescarbot describes a winter hunting trip of the savages, when with their dogs they sought out the moose, helpless by reason of the deep snow on which crust had formed. "We made a very luxurious repast with this tender venison," he writes. "After the roast we had soup, quickly prepared in abundance by a savage who made a trough with his ax, from the trunk of a tree, in which he stewed the meat. . . . This was accom-

8 "Premièrement parlons de l'Ellan lequel ils appellent A ptaptou, \& noz Basques Orignac. . . . C'est la plus abondante manne qu'ayent les Sauvages apres le poisson."-Lescarbot, Histoire de la Nouvelle France (Paris, 1609), p. 811. 
plished by putting stones, brought to a red heat in the fire, into the trough, and renewing them until the meat was cooked. Joseph Acosta says that the savages of Peru do the same thing."9

An Indian banquet which Champlain witnessed near the mouth of the Saguenay he thus described: "After he had finished his speech we left his cabin, and they began their tabagie or feast, which they make with the flesh of the orignac (which is like beef), the bear, seals, and beavers, which are their most common meats, and game birds in quantity. They had eight or ten kettles, full of meat, in the cabin. These were some six paces from each other, and each with its own fire."

The guests were seated on two sides of the cabin, each having his own bark dish. Champlain was not favorably impressed by the table manners of the Indians. "They eat in a very filthy manner," he wrote, "for when their hands are greasy they wipe them on their hair, or on their dogs, of which they keep many for hunting."

Some years later Nicolas Denys, who lived among the Indians of Acadia, described the Indian method of making kettles. Huge fallen trees

- Ubi supra, p. 813.

ro Des Sauvages, ou, Voyage de Samuel Champlain, de Brouage, faict en la France nouvelle, l'an mil six cens trois (Paris, 1604), fol. 4 . 
were utilized, the upper surface being leveled off, and a trough-like excavation made by the use of fire and stone axes. These kettles, laboriously made, determined the places of their camps, until the white men brought iron kettles, which could be easily carried on their journeys. ${ }^{\text {II }}$

Until the introduction of gunpowder the American Indian was practically on even terms with the European hunter in respect to weapons for the chase. He still used stone, or pointed bones, instead of metal, for the heads of his spears and arrows, but his cleverness in fashioning barbed spear heads and arrow heads, with wonderfully sharp edges, from flint, and in fixing them to the shafts, cannot be equaled by the men of today.

Many of the Old-World hunters had replaced the long-bow by the cross-bow, and some had supplanted both by the arquebus, at the time when the Old World and the New first met. But the effective range of the early firearms was wofully short. According to Greener, "a reliable match decided at Pacton Green, Cumberland, in August, I792, resulted in a grand victory for the bow. The distance was one hundred yards, the bow placing

"Description Géographique et Historique des Costes de l'Amérique Septentrionale (Paris, I672), vol. ii., p. 359. 
sixteen arrows out of twenty into the target, and the ordinary musket twelve balls only." ${ }^{2}$

The Indian's bow was not so long as the Englishman's, but he was very skilled in its use. Denys wrote from Acadia in 1672 that its effective range against moose was forty-five or fifty paces, ${ }^{{ }^{13}}$ a range which offered less difficulty to the stealthy, soft-footed Indian than to us who are accustomed to walk on city pavements.

The snares and pitfalls devised by the Indians, and the barriers erected to guide driven game into slaughter pens, as described by the earliest European visitors to America, show a marked resemblance to the contrivances in use for the same purposes in medieval Europe. Necessity is the mother of invention, and we need not wonder if similar necessities produced similar inventions.

The narratives of the earliest European explorers in America are given in the great folios which Samuel Purchas published in 1625 under the title Purchas His Pilgrimes. Quoting Sir Ferdinando Gorges he thus describes the moose:

"There is also a certaine Beast, that the Natives call a Mosse, hee is as big bodied as an Oxe. . . . His taile is longer then the Single ${ }^{14}$ of a Deere,

13 The Gun and Its Development, sixth edition (1897), p. I2.

${ }_{3}$ Ubi supra, vol. ii., pp. 420-423.

$x$ The tail of a buck. 
and reacheth almost downe to his Huxens. ${ }^{15}$. . . There have beene many of them seene in a great Iland upon the Coast, called by our people Mount Mansell, ${ }^{16}$ whither the Savages goe at certaine seasons to hunt them [by driving into the water]. ... And there is hope that this kind of Beasts. may be made serviceable for ordinary labour, with Art and Industry."

At the time of its publication in 1634 William Wood's New Englands Prospect was the most complete account of New England, its climate, soil, fauna, etc., which had been written. The author had spent four years in the Colony. He wrote in a light vein, possessed a lively imagination, and sometimes dropped into verse, his enumeration of the beasts of the country being in the following lines:

The kingly Lyon, and the strong arm'd Beare The large lim'd Mooses, with the tripping Deare, Quill darting Porcupines, and Rackcoones bee, Castelld in the hollow of an aged tree;

15 Hock.

${ }^{16}$ Mount Desert Island.

${ }^{7}$ Furchas His Pilgrines (London, 1625), tenth book, "English Discoveries and Plantations in New England and New-found-land," chap. i. Gorges, $A$ Brief Relation of the Discovery and Plantation of New England (London, 1622), pp. 26-27. An earlier mention of the moose by this name-perhaps the earliest in any book-appears in the edition of Purchas's Pilgrimage published in 1614, p. 755: "Captaine Thomas Hanham sayled to the Riuer of Sagadahoc 1606. He relateth of their beasts . . . redde Deare, and a beast bigger, called the Mus." 
The skipping Squerrell, Rabbet, purblinde Hare,

Immured in the selfesame Castle are,

Least red-eyd Ferrets, wily Foxes should

Them undermine, if rampird ${ }^{\mathrm{r} 8}$ but with mould.

The grim fac't Ounce, and ravenous howling Woolfe,

Whose meagre paunch suckes like a swallowing gulfe.

Blacke glistering Otters, and rich coated Bever, The Civet sented Musquash smelling ever. ${ }^{10}$

"The beast called a Moose," he explains, "is not much unlike red Deare, this beast is as bigge as an Oxe; slow of foote, headed like a Bucke, with a broade beame, some being two yards wide in the head, their flesh is as good as Beefe, their hides good for cloathing; The English have some thoughts of keeping them tame, and to accustome them to the yoake, which will be a great commoditie: First because they are so fruitfull, bringing forth three at a time, being likewise very uberous. Secondly, because they will live in winter without any fodder. There be not many of these in the Massachusets bay, but forty miles to the Northeast there be great store of them; These pore beasts likewise are much devoured by the Woolves."

Thomas Morton, the gay roysterer of Merry

${ }^{88}$ Ramparted.

"Part I., chap. vi. 
Mount, who was devoted to hunting, described New England and its resources in his New English Canaan. Morton wrote "upon tenne yeares knowledge and experiment of the Country." In the fifth chapter of his second book, "Of the Beasts of the forrest," he describes three kinds of deer.

"First, therefore I will speake of the Elke, which the Salvages call a Mose: it is a very large Deare, with a very faire head, and a broade palme, like the palme of a fallow Deares horne, but much bigger, and is 6 . footewide betweene the tipps, which grow curbing downwards: Hee is of the bignesse of a great horse.

"There have bin of them, seene that has bin 18 . handfulls highe: hee hath a bunch of haire under his jawes: he is not swifte, but stronge and large in body, and longe legged; in somuch that hee doth use to kneele, when hee feedeth on grasse.

"Hee bringeth forth three faunes, or younge ones, at a time; and being made tame, would be good for draught, and more usefull (by reason of their strength) then the Elke of Raushea. These are found very frequent, in the northerne parts of New England, their flesh is very good foode, and much better then our redd Deare of England.

"Their hids are by the Salyages converted into very good lether, and dressed as white as milke. 


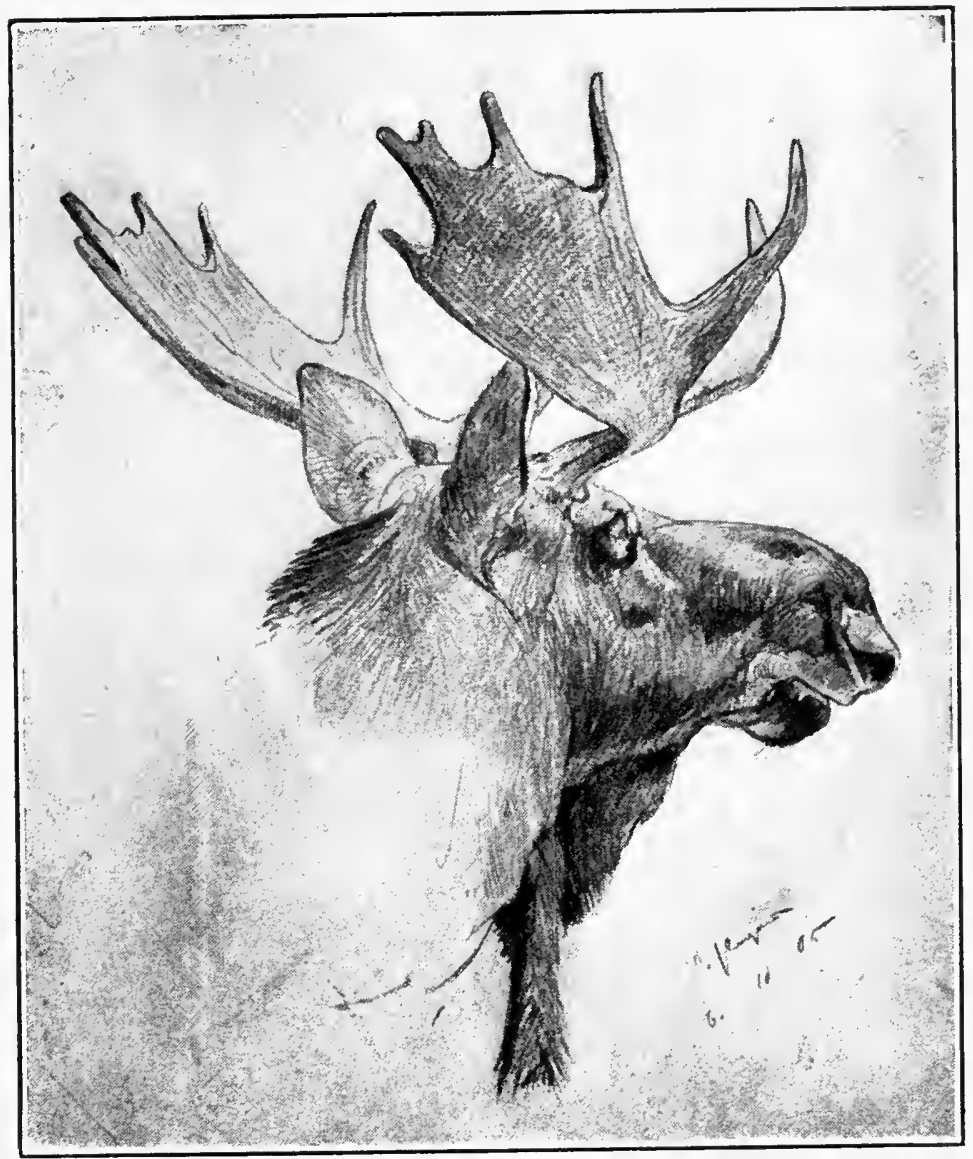

(C) by Carl Rungius

Antlers at About Five Years of Age

From a Drawing by Carl Rungius. (Renous River, N. B.) 

"Of this lether, the Salvages make the best shooes, and use to barter away the skinnes to other Salvages, that have none of that kinde of bests in the parts where they live. Very good buffe may be made of the hids, I have seene a hide as large as any horse hide that can be found. There is such abundance of them that the Salvages, at hunting time, have killed of them so many, that they have bestowed six or seaven at a time, upon one English man whome they have borne affection to." 20

With the establishment of the Jesuit missions in New France in I6I I a new class of writers began making contributions to the history of the moose. The missionaries in their Relations, or reports of the events in their forest parishes sent from year to year to their superiors in the old country, make frequent mention of the animal which they call l'élan or l'orignal. Like the Indians, the priests were dependent on the moose for food in winter, and like the Indians they went hungry when for lack of deep crusted snow the hunters with their primitive weapons were unable to

so New English Canaan (Amsterdam, 1637), pp. 74-75. Morton was a lawyer of Clifford's Inn, London. His unpuritanical conduct twice entailed banishment from New England, and after the publication of his "scandalous book" his return to Boston brought him a year in prison. 
capture game. Often they tell of sustaining life by eating acorns, lichens, and remnants of moose skin, because the hunt had failed. ${ }^{21}$

"The snow not being deep, as in other years," wrote Fr. Bressani, an Italian missionary, in 1653 , "they could not take the great beasts ["gran bestie,' moose,] but only some beavers or porcupines. ... An eelskin was deemed a sumptuous supper; I had used one for mending my robe, but hunger obliged me to unstitch and eat it. We ate the dressed skins of the great beast, though tougher than that of the eels. I would go into the woods to gnaw the tenderest part of the trees, and the softer bark. . . . The snow came toward the end of January, and our hunters captured some great beasts, and smoked their flesh, so much that it became as hard as a stick of wood." . . . Meanwhile some of the Indians in the neighborhood died of starvation. ${ }^{22}$

The Indians were the principal hunters of moose, though it was recorded that "many of our Frenchmen have killed thirty or forty apiece." The skins were an important article of commerce, and at Tadousac, a trading post at the mouth

2x Jesuit Relations (Cleveland, 1899), vol. 1v. (1670-71), pp. 151153; vol. xxxvii., pp. 193-195

22 Ibid., vol. xxxix., pp. 113-115.

23 Ibid. (1659-60), vol. xlv., p. 193 . 
of the Saguenay, more than five hundred moose skins were handled in the way of trade in $1648 .{ }^{24}$ This of course did not include the many used by the savages in making their clothing. ${ }^{25}$

Several writers suggested the possibility of domesticating the moose, hoping thus to avoid some of the hardships of their long journeys to the distant missions. Fr. Le Jeune, superior of the "Residence of Kebec," wrote in 1636 that the French Governor had two bull moose and one cow in captivity, which he was seeking to domesticate. ${ }^{26}$ The experiment was evidently a failure, for no further mention of the captives is made.

Many accounts are given of the Indian feasts. These functions were frequent, and varied in character, but the gluttony of the red men in times of plenty, and the disregard of rules of cleanliness in preparing the food, make the savage banquets seem anything but attractive.

Each guest took with him to the feast his own bark dish and wooden spoon. The choicer por-

24 Jes. Rel., vol. xxxii., p. I03.

25 A good description of the moose-skin garments of the Indians is given by Fr. Le Jeune, writing in 1634-35. See Jes. Rel., vol. vii., pp. 15-17. The skin of the moose as material for clothing was valued by the white man also. Alexander Bradford of Dorchester, Mass., by his will, proved in 1645 , bequeathed a "Moose Suite \& a musket \& Sworde \& bandilieres \& vest." (New England Historical and Genea. logical Register, vol. iii. [I849], p. 82.)

${ }_{26}$ Jes. Rel., vol. ix., pp. 131, 165. 
tions were not divided. The tongue of a moose would be given to a single person, the tail and head of a beaver to another. These were the best pieces, and were called "the captain's part." "As for the fat intestines of the moose, which are their great delicacies, they usually roast them, and let every one taste them, as also another dish which they hold in high esteem, namely, the large intestine of the beast filled with grease, and roasted, fastened to a cord, hanging and turning before the fire." ${ }^{27}$

In seasons of plenty some of the meat would be dried and smoked for future use. As a preliminary the juice would be forced out, as far as possible, by pounding with stones and trampling with the feet. Whole sides of moose would be dried at once, the bones being removed, and where the masses of flesh were thick, deep slashes would be cut to enable the smoke to penetrate. ${ }^{28}$ The missionaries speak often of eating this dried

7 Fr. Le Jeune, writing in 1634. See Jes. Rel., vol. vi., p. 281.

${ }^{28}$ Ibid., vol. vi., p. 297. The dried meat of the western country is first cut into thin strips, and is seasoned with pepper and salt. The strips are laid for drying on a framework of poles about four feet from the ground, and a slow fire, preferably of black birch, furnishes heat and smoke for the curing process. When required for use the meat is pounded fine and made into soup, but it may be eaten dry. This sort of meat is commonly called "jerky" - a corruption of "charqui," a Peruvian word meaning dried meat.-See Kephart, Book of Camping and Woodcraft (N. Y., I906), p. 222. 
meat, but none of them have any compliments to waste on it. It was hard and tasteless-but it would support life.

The savages made no use of salt in their food, and vegetables and cereals were often lacking. The sole dish at many of their tabagies, or feasts, was an unseasoned stew into which were thrown masses of any meat that happened to be at hand, without regard to any culinary rules.

In a vellum-bound folio, profusely illustrated with steel-plate engravings, Arnoldus Montanus told the people of Holland in the seventeenth century of the wonders of the two Americas. His book is entitled The New and Unknown World; or Description of America and the Southern Land."9 It was published in Amsterdam in I67I. A translation of Montanus's Description of New Netherland is given in O'Callaghan's Documentary History of the State of New York. ${ }^{30}$ New Netherland, according to the Dutch writer, was bounded by Virginia on the southwest, by New England on the northeast, by the ocean on the southeast, and by the River Canada (St. Lawrence) on the

29 De Nieuwe en Onbekende Weereld: of Beschryving van America en ' $t$ Zuid-land.

${ }^{30}$ Published in Albany, 1851 ; see vol. iv., pp. 75-83. 
north, while "northwesterly, inland, it remains wholly unknown."

"South of New Netherland," writes Montanus, "are found numerous elks (eelanden), animals which, according to Erasmus Stella, ${ }^{31}$ constitute

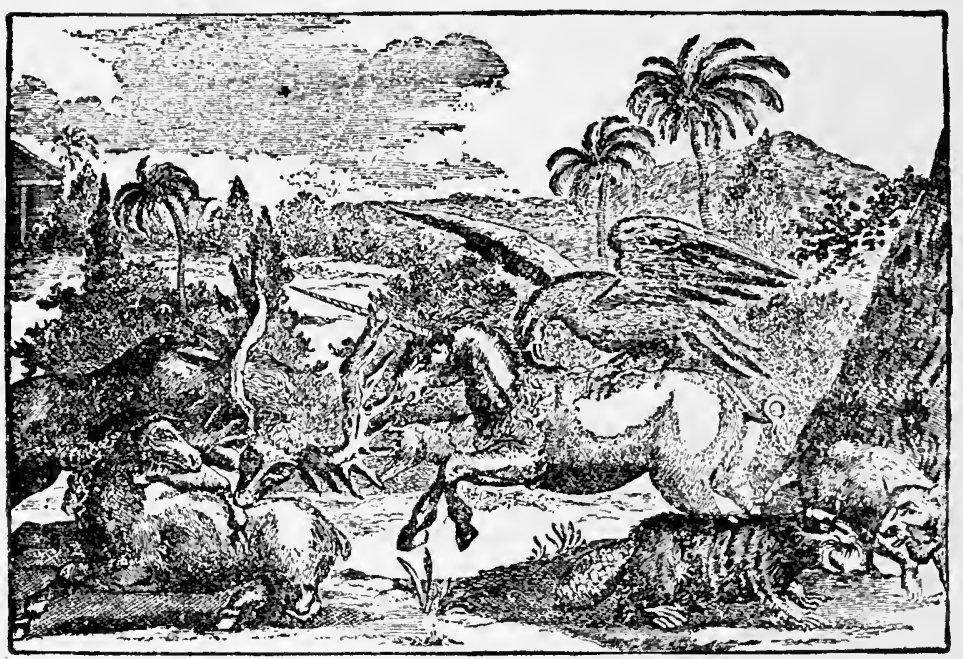

Game in New Netherland

a middle class between horses and deer. They appear to derive their Dutch appellation from elende (misery), because they die of the smallest wound, however strong they may otherwise be; also, because they are frequently afflicted with epilepsy. ... When hunted they spew hot water

${ }^{3 \times}$ Stella wrote, in Latin, early in the sixteenth century, of the elk of Prussia. 
out on the dogs. They possess great strength of hoof, so as to strike a wolf dead at a blow. Their flesh, either fresh or salted, is very nutritious; the hoofs cure the falling sickness."

Montanus was evidently writing of the moose, which is the elk of Europe, but he was clearly at fault in placing the habitat of the moose south of New Netherland. His plate, showing some of the wild animals of New Netherland, is reproduced herewith. In it are shown the moose, the unicorn (which Montanus said was found "on the borders of Canada"), and a great blood-drinking eagle. A beaver, in the foreground of the picture, seems to be amused at the company in which he finds himself.

John Josselyn, an English physician, the son of a baronet, who made two extended visits to New England in the seventeenth century, spending much of his time in what is now Maine, has left us a description of the moose.

"The Moose or Elke is a Creature, or rather if you will a Monster of superfluity," he writes. "A full grown Moose is many times bigger than an English Oxe, their horns as I have said elsewhere, very big (and brancht out into palms) the tips whereof are sometimes found to be two fathom asunder ( $a$ fathom is six feet from the tip of one finger to the tip of the other, that is four cubits), 
and in height from the toe of the forefoot, to the pitch of the shoulder twelve foot, both which hath been taken by some of my sceptique Readers to be monstrous lyes." 32

Before we criticise too severely Josselyn and others of his time who made statements which seem to us willfully exaggerated, we should consider the circumstances under which they wrote. Credulity, not mendacity, was the failing of the age. Independent thought and research were discouraged, and in some fields forbidden. The gallows had not yet been erected on which to hang the witches of Salem. . . . Perhaps someone had seen limbs of small trees broken by browsing moose at a height of twelve feet from the ground, and had foolishly assumed and asserted that there were moose in the woods which were twelve feet tall: if Josselyn had seen a thousand moose, none of which exceeded six feet in height, he would have been simply following the example of his age if he accepted the larger dimension without a question.

In his earlier work, New Englands Rarities Discovered (London, 1672), Josselyn paid some attention to the medicinal and culinary qualities

32 An Account of Two Voyages to New England, by John Josselyn, Gent. (London, 1674), p. 88. 
of the moose. "Their flesh is not dry like Deers flesh," he writes, "but moist and lushious somewhat like Horse flesh (as they judge that have tasted of both) but very wholsome. The flesh of their Fawns is an incomparable dish, beyond the flesh of an Asses Foal so highly esteemed by the Romans, or that of young Spaniel Puppies so much cried up in our days in France and England."

The scientific men of Josselyn's time took the old doctor seriously, and his account of the moose was published in the Transactions of the Royal Society of London, "to the right honourable and most illustrious the President \& Fellows" of which he dedicated his book.

Another writer in the Transactions of the Royal Society was Hon. Paul Dudley, F.R.S., Chief Justice of the Province of Massachusetts Bay. Judge Dudley lived in Roxbury, which is now a part of Boston. His paper, published in $172 \mathrm{I}$, is entitled $A$ Description of the Moose-Deer in America. His statements are derived "partly from my own Knowledge, and partly from the Information of Men of Ingenuity and Probity, that are better acquainted with it."

Judge Dudley begins by referring to Josselyn's account of the moose, which he called "imperfect." "Of Moose there are two sorts," he writes, 
"the Common light grey Moose, by the Indians called $W$ ampoose; ${ }^{33}$ these are more like the ordinary Deer, spring like them, and herd sometimes to thirty in a Company. And then there are the large, or black Moose, of which I shall now give you the following Account. First, That he is the Head of the Deer-kind, has many things in Common with other Deer, in many things differs, but in all very superiour. ... He has a very short Bob for a Tail. Mr. Neal, in his late History of this Country, speaking of the Moose, says they have a long Tail; but that Gentleman was imposed on, as to other things besides the Moose. Our Hunters have found a Buck, or Stagg-Moose, of fourteen Spans in heighth from the Withers, reckoning nine inches to a Span; a quarter of his Venison weighed more than two hundred pounds. A few Years since, a Gentleman surprized one of these black Moose, in his Grounds within two miles of Boston; it proved a Doe or Hind of the fourth Year: After she was dead, they measured her upon the Ground, from the Nose to the Tail, between ten and eleven Feet, she wanted an Inch of seven Foot in height. The Horns of the Moose, when full grown, are between four and five Foot from the Head to the Tip, and have seven Shoots ${ }_{33}$ The wapiti. 



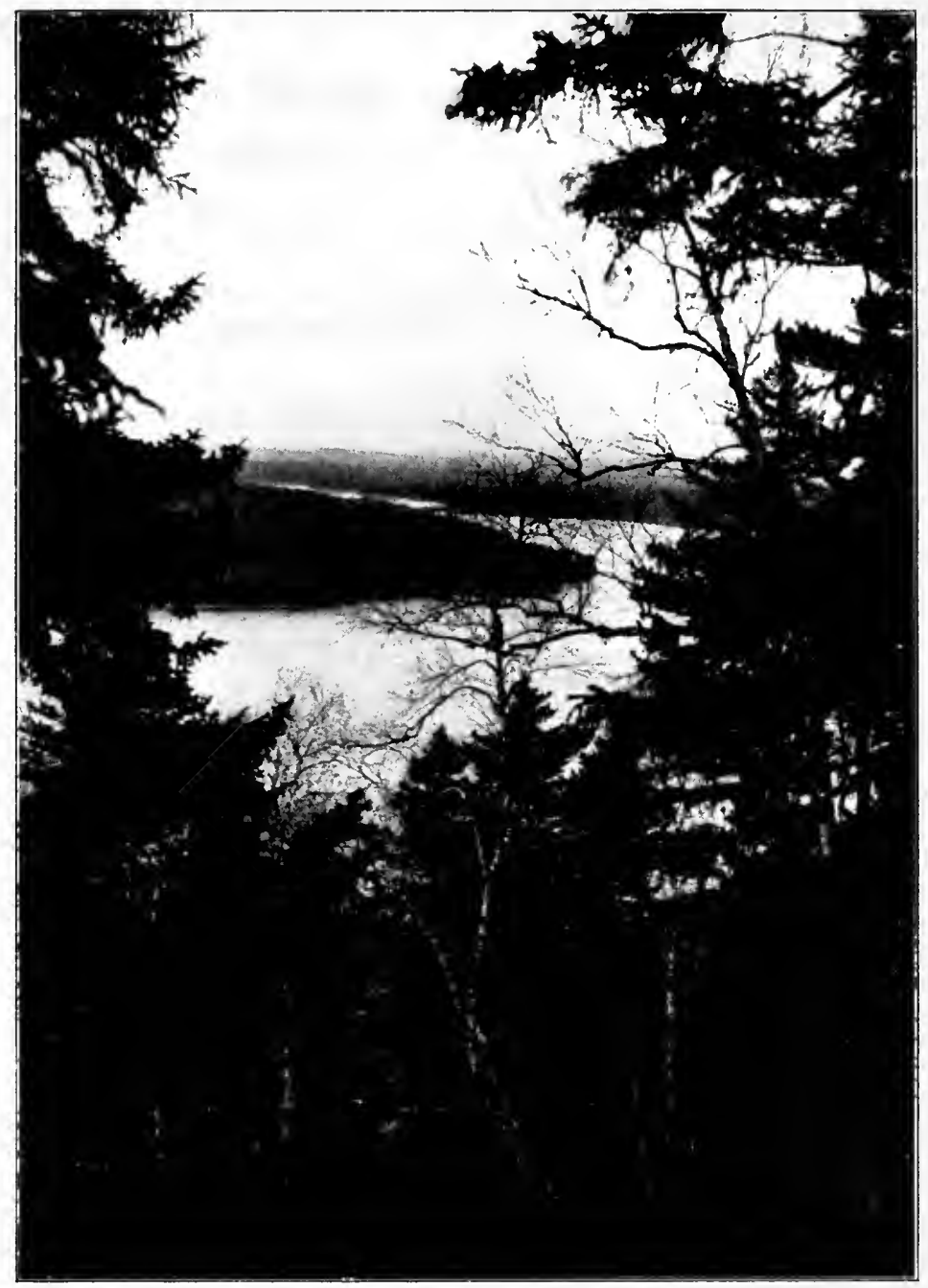

In the Heart of the Moose Country 
or Branches to each Horn, and generally spread about six Foot." 34

The range of the moose will be discussed in a subsequent chapter. The causes which would affect the numbers of moose within this range were very different in the Colonial period from those which prevail today. The moose's enemies were then wild animals and crust-hunting Indians who were only a little less wild. He enjoyed no protection from the law-makers, but he was not required to face modern firearms. How the winter death-rate among those of his species two centuries ago would compare with the autumn death-rate in this era of game laws and high-power rifles will always be a matter of speculation.

Champlain on his map of New France, drawn in 1632, notes "Chasse des Eslans" in three places on the Gaspé Peninsula, but no doubt moose were equally numerous through a vast area south and west of that section.

Gabriel Sagard-Theodat, who visited the various Indian missions in Canada a few years after Champlain's time, writes: "Les eslans ou orignats . . . sont frequents $छ$ en grand nombre au pays des Montagnais, E fort rare à celuy des 34 Philosophical Transactions of the Royal Society, 1721, pp. 165 et seq. 
Hurons." ${ }_{35}$ This may be freely translated by saying that moose were found in great numbers in the country north of the lower St. Lawrence River, but were very rare in the district between Georgian Bay and Lake, Ontario.

In the latter half of the seventeenth century Peter Esprit Radisson, a French trader who wrote an account of his travels in English, made extended journeys to Hudson Bay, and to the upper Mississippi Valley. Telling of a season spent in the region southwest of Lake Superior he wrote: "The spring approaches, $w^{\text {ch }}$ [is] the fitest time to kill the Oriniack. A wildman and $\mathrm{I} \mathrm{w}^{\text {th }}$ my brother killed that time above 600 , besides other beasts." ${ }_{36}$ Perhaps moose were a little less numerous than Radisson's statement would imply. Most of us will question, at any rate, whether their antlers were as heavy as he would have us believe. Writing about 1660 he says: "I have seene of their hornes that a man could not lift them from of the ground. They are branchy $\&$ flatt in the midle, of $\mathrm{w}^{\text {ch }}$ the wildman makes dishes $\mathrm{y}^{\mathrm{t}}$ can well hold three quarts." ${ }_{3 i}$

Denys wrote in 1672 that moose, which formerly

35 Histoire du Canada (Paris, I636), p. 749.

${ }^{36}$ Voyages (Boston, I885), p. 220. Collections of the Minnesota Historical Society, vol. x., part ii. (St. Paul, 1905), pp. 502-505.

37 Voyages, p. 156. 
were found in great numbers on the island of Cape Breton, had been exterminated by the Indians, and that the Indians themselves had then been forced to abandon the island for lack of game. ${ }^{38}$ Prince Edward Island also was destitute of moose, though there were some caribou, "which are another species of moose." 39

Perhaps the disappearance of this class of game from the Acadian Islands was due to the commercial demands of Europe. Describing the territory at the head of the Bay of Fundy Denys wrote: "The Sieur d'Aunay in his time [1645-1650] traded in moose skins there to the extent of 3000 skins a year, besides beaver and otter, which was the reason why he dispossessed the Sieur de la Tour of it." ${ }^{40}$ No doubt many of the Cape Breton and Prince Edward Island moose skins had gone to the European market by way of Sieur d'Aulnay's trading post. The Indian killed only to supply his simple needs, until the white man came and sought skins for export. But the price of peltries was paid in the Frenchman's brandy, ${ }^{4 \mathrm{r}}$ and the death-rate among the moose soon mounted rapidly.

${ }^{8}$ Description Géographique et Historique des Costes de l'Amérique Septentrionale. Avec l'Histoire naturelle du Pais. Par Monsieur Denys, Gouverneur Lieutenant-Général pour le Roy, vol. i., p. I63.

39 Ubi supra, vol. i., p. 202.

40 Ubi supra, vol. i., p. 50.

42 Denys, vol. ii., chap. xxvii. 
Moose and beaver skins were chiefly in demand. From the former buff-leather was produced. This was a soft, pliable, uncolored leather, originally made from the skins of the buffaloes of the Eastern Hemisphere. It was used for clothing, and many other purposes.

Charlevoix, who lived in Quebec as a Jesuit missionary for four years following 1705 , writing (March II, I72I) from St. Francis on the St. Lawrence, says that moose had been very numerous in that vicinity at the time of the first settlement of the colony, but had been heedlessly slaughtered, or frightened away, by "those who preceded us in this country." ${ }^{42}$ And Fr. Sébastien Rasle, in a letter to his brother from Narantsouak (now Norridgewock, Maine), wrote: "Our savages have so destroyed the game of their country that for ten years they have no longer either moose [orignaux] or deer [chevreuil]. Bears and beavers have become very scarce. They seldom have any food but Indian corn, beans, and squashes." 43 This was written October 12, I723, less than a year before the missionary's tragic death.

As colonization advanced the moose retreated.

42 Journal d'un Voyage fait par Ordre du Roi dans l'Amérique Septentrionale, Paris, 1744 .

${ }^{43}$ Jesuit Relations, vol. lxvii., p. 213. 



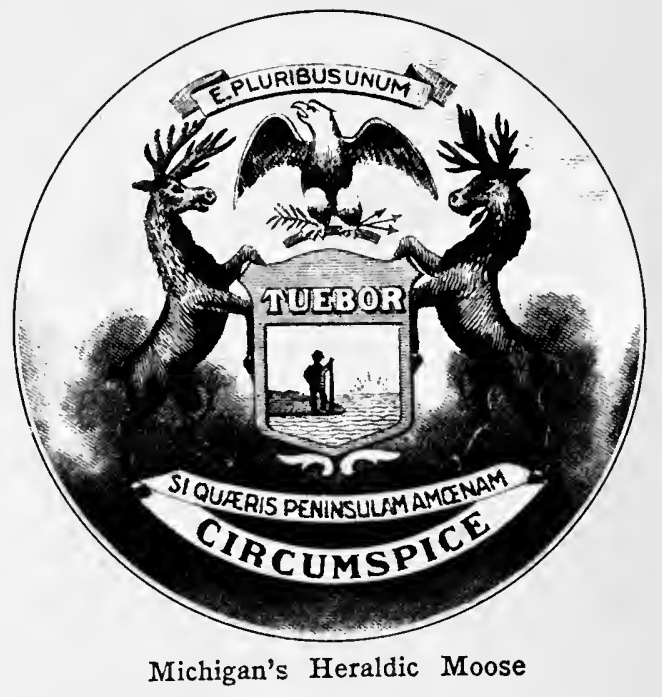


In the hunting territory which was easy of access the heedless slaughter of which Charlevoix complained continued through the Colonial period, and the larger game animals became a constantly diminishing factor in the life of the white settlers. As for the Indians of Maine and Canada, it was necessary for them to make longer and longer journeys in the winter, to find this class of game in the profusion to which they had been accustomed.

The early histories of the northern States remote from the seaboard contain few references to the moose. The settlers were too busy to engage in hunting for its own sake, and game soon became an immaterial consideration with them as a source of food supply. With the Indians it was different. Schoolcraft, writing in Territorial days of the natural resources of Michigan, says: "The moose is confined to the portions of country northwest of Lake Huron, where it is still relied on by the Indian tribes as among the means of their precarious subsistence." ${ }_{44}$

A reminiscence of the time when the moose still frequented the northern woods of Michigan, is found in the coat-of-arms of that State. This coat-of-arms, as blazoned on the Great Seal, has

44 Historical and Scientific Sketches of Michigan (Detroit, 1834), p. 185. 
for supporters a conventionalized moose rampant on one side and a wapiti rampant on the other. ${ }^{45}$

In Canada conditions were similar. But the great wooded wilderness of the north was never far away, and moose are, and always will be, a more important economic factor in the Dominion than in the States farther south. Robert Bell, Jr., in an article on the Natural History of the Gulf of St. Lawrence, published in the Canadian Naturalist and Geologist in 1859, said: "For the last few years most of the hunters have devoted their time to killing the moose simply for the sake of their skins, which now command a higher price than formerly, and this they do at any season of the year which suits their own convenience. We were informed that a party of these hunters had procured three hundred skins the previous winter, and that another party of only three Indians had killed during the same season between ninety and one hundred on one expedition, as many as six sometimes falling a prey to them in one day, yet still these noble animals roam in vast numbers over the district."

45 The seal was adopted in 1835 . A rampant moose and a rampant wapiti support also the coat-of-arms of Ontario. The recumbent moose on the State seal of Maine, lying at the foot of a pine tree, more accurately represents the tranquil disposition of the animal during most of the year. 
Mr. Bell was writing of the district south of the lower St. Lawrence River, including the Gaspé Peninsula, and he referred to the winter of $1857^{-}$ 58. Since that time legislation in all the political divisions of the moose's American range has checked the "heedless slaughter" which threatened the future of the species, and happily there is now no occasion to apprehend extermination of the moose in either hemisphere. 


\section{CHAPTER II}

AMERICAN RANGE OF THE MOOSE

THE changes which have taken place in the range of the moose since the first Europeans came to this continent are not great. Moose are not being exterminated, as some assert. In some sections of their territory they are unquestionably losing ground, but "they have acquired within our present history of them almost or quite as much territory as they have lost."'

The southernmost points in the present American range of the moose are southern Nova Scotia and southern Idaho and Wyoming. Between these extremes the boundary of the range has wavered as the activity of hunters and the foresight of lawmakers have modified conditions from time to time. Moose have been more numerous in New Brunswick and Maine in the past twenty or twenty-five years than at any time in the previ-

. Andrew J. Stone, in The Deer Family (New York, 1902), p. 302. Mr. Stone is exceptionally well qualified to speak of the moose of Alaska and the Canadian Northwest. 



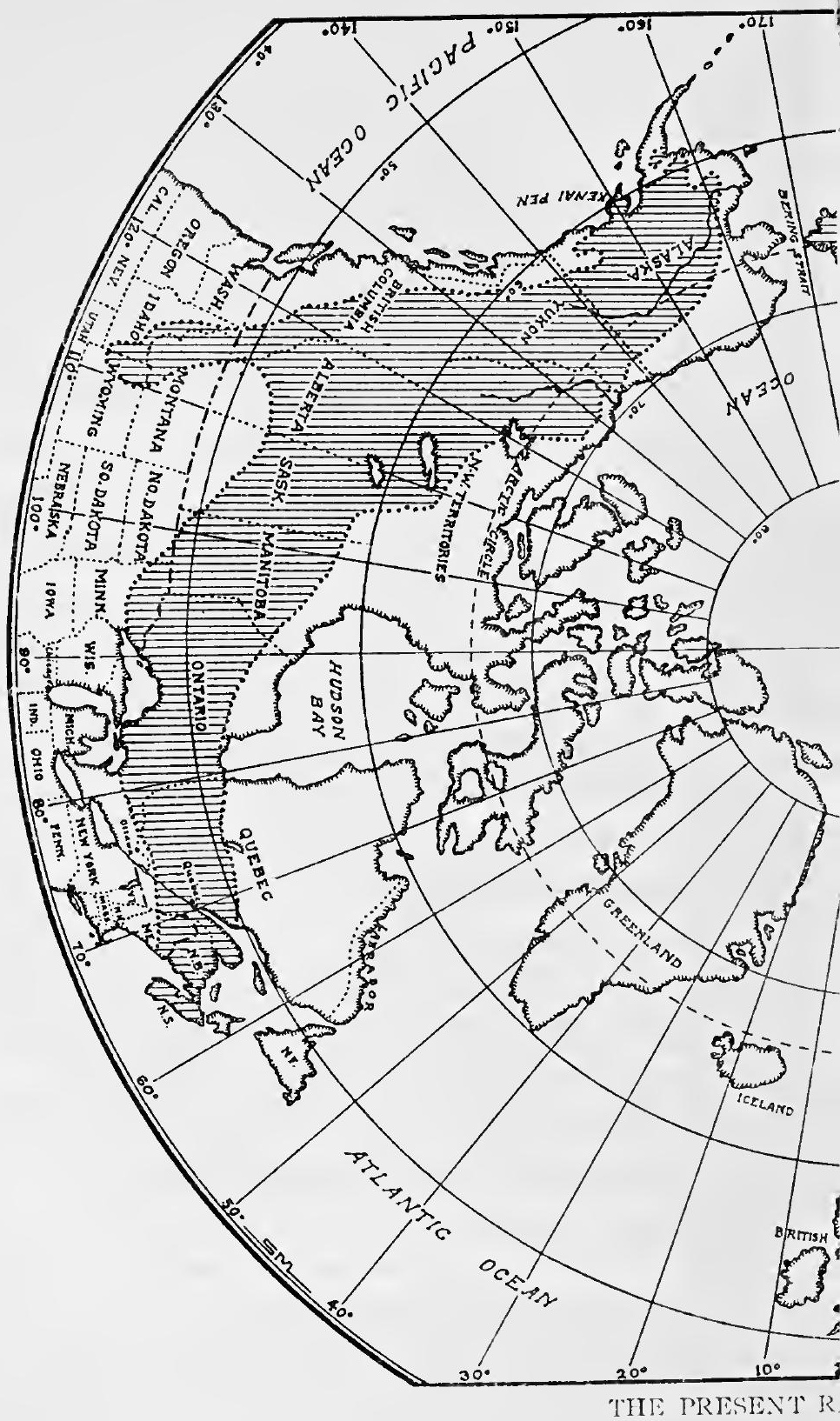




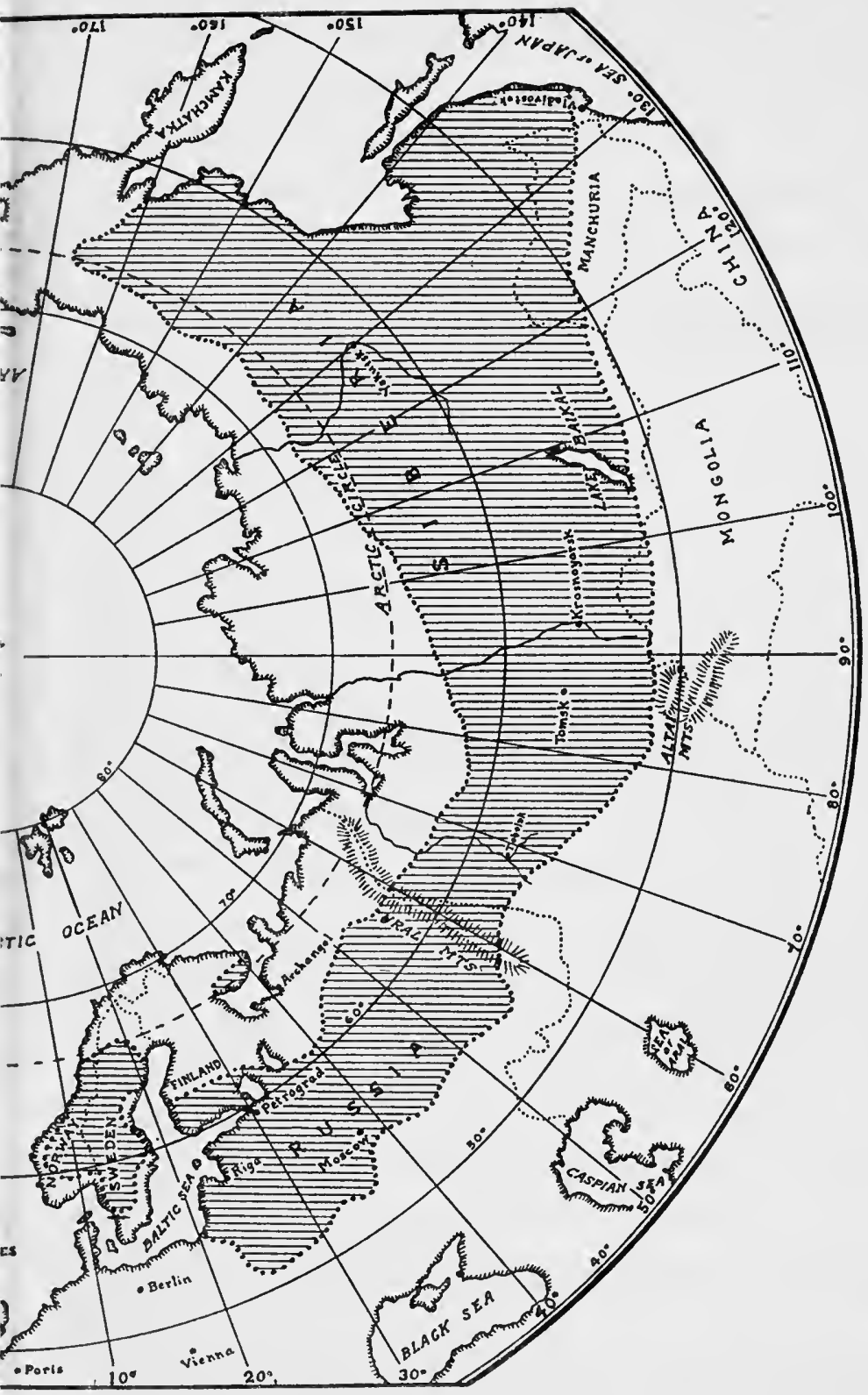

OF CERVUS ALCES 

ous half-century, thanks to wise legislation. They lost their foothold in New Hampshire only thirty years ago, five having been killed near the Connecticut Lakes in 1884 . Thirteen years earlier there were said to be some still remaining in northern Vermont. ${ }^{2}$

Before the advent of the white hunter moose are believed to have exceeded the deer in numbers in the Adirondacks. These woods were a favorite hunting ground of the Six Nations, and of the Canadian Indians, who prized highly the moose meat secured there for winter use. And the animals continued fairly plentiful in this portion of their range until the beginning of the second half of the nineteenth century.

The last refuge of the moose in the Adirondacks was in the country between Raquette Lake and Mud Lake. Their disappearance was partly due to sudden migration, about 1854 or 1855 , dogs employed to chase deer driving the moose into parts unknown. But unrestrained slaughter of bulls, cows, and calves completed the extinction of the species in the great "North Woods."

Governor Horatio Seymour shot a bull in 1859 , near Jock's Lake, Herkimer County, N. Y., and

2 "The Vanishing Moose," by Madison Grant, Century Magazine, January, I 894 . 
it used to be said that this was the last moose killed in the State. But a number appear to have been shot later. In 1860 "Alva Dunning killed several on West Canada Creek." In August, I86I, however, a cow was killed at Raquette Lake which was "the last known native of its race in New York State." A party of four men from Philadelphia, including a lawyer and a physician, with two guides, were on a fishing trip, in two boats, when they encountered the moose. One of the sportsmen fired a charge of buckshot into her shoulder at fifty yards' distance; another fired a charge of No. 6 shot; the guides each added a rifle ball-and the curtain was rung down on the inglorious tragedy of extermination. ${ }^{3}$

Vain attempts have since been made to restock the Adirondacks with moose. In 1902 seven or eight specimens were obtained, chiefly from Canada, and released. The following year four or five more were secured. Several were "mistaken for deer" and shot; the others presumably found their way northward to Canada again. The experiment cost the State about $\$ 3000$, and ended in failure.

Moose occasionally stray beyond their ordinary

${ }^{3}$ Madison Grant, ubi supra. The Mammals of the Adirondack Region, by Clinton Hart Merriam, M.D. (N. Y., I 884), pp. 141-I 43 . 
range. Thus they were reported in the early Colonial days in the Catskills of New York, in the Berkshire Hills of Massachusetts, and in the northeastern portion of the same State. Judge Dudley stated in $172 \mathrm{I}$ that a cow moose was killed "a few years since" within two miles of Boston." But these must all be considered as merely visitors, and not settled residents. Since the advent of white men the moose's recognized range has never reached so far south on the eastern side of the continent as the northern boundary of Massachusetts.

Hon. William C. Whitney secured three pairs of moose for his October Mountain preserve in Lee, Berkshire County, Mass., about 1900. One pair was taken to a sportsmen's show in New York: of these one died and the survivor was returned to his former home in Manitoba. The moose remaining in the preserve bred well, the increase aggregating about twenty head. The enclosure of $\mathrm{r} 200$ acres is surrounded by nearly ten miles of wire fence. Four or five years ago the fence was maliciously cut and seven or eight moose escaped. Three of these are known to have been killed illegally. A dozen moose from this source are believed to be at large now in the Berkshire Hills. ${ }_{4}$ See p. 24. 
The number in the preserve at present is only four, but they share the enclosure with two bull elk and several blacktail deer. It is believed the experiment would have been more successful if the moose had been given exclusive possession of a larger preserve. ${ }^{5} \quad$ A similar experiment with moose was undertaken about the same time by Austin Corbin at the Blue Mountain preserve in Sullivan County, N. H., but it was given up after a few years.

Moose have enjoyed legal protection in Michigan since I889. A few are found on Isle Royale, near the northern shore of Lake Superior, and in the northern peninsula of the State a very few scattered specimens are occasionally reported. These are believed to be wanderers which have crossed from Canadian territory on the ice. It is sometimes reported also that moose have been seen in the extreme northern part of Wisconsin, but such reports in recent years have not been substantiated. Animals of this species have not been numerous in either Michigan or Wisconsin within the memory of any now living.

In the tamarack swamps of northern Minnesota

's For information regarding the moose of the October Mountain preserve the author is indebted to William W. Sargood of Lee, Deputy Fish and Game Commissioner of Massachusetts. 
moose are found in considerable numbers. "The United States Forest Service estimates approximately 1500 moose in the Superior National Forest, ${ }^{6}$ and this estimate is conservative. There are probably as many more outside the refuge. The annual kill of moose [in Minnesota], legal and otherwise, not including toll taken by wolves, is probably not over 200 animals."7

Westward, from Minnesota to the Rocky Mountains, the plains afford little suitable cover, and moose are not found. The mountains of western Montana and eastern Idaho, and the adjacent Wyoming region, however, harbor some moose, but the heads are inferior, and hunting is not generally permitted. Glacier National Park, in northwestern Montana, comprises 1400 square miles. W. W. Payne, superintendent of the park, in his report for the year ending June 30 , I9I9, says: "Moose are found in considerable numbers around the lakes of the Flathead Valley." This is a wild region of Alpine character on the western slope of the Continental Divide.

\section{- See Appendix, page 363 .}

7Report of the State Game and Fish Commissioner, July 31, 1918, p. 26. Moose are much more prolific than most species of deer, and the natural increase, if these estimates are correct, could be expected to offset the losses due to hunting and to the depredations of wolves, leaving an ample margin to add to the State's present stock. 
In 1897 the Government had fifty moose under its protection in the Yellowstone Park. In I9I2 these had increased to 550 , according to official reports. Hon. George Shiras, 3d, during a trip in the Yellowstone Park in September and October, I9IO, counted four hundred moose, seeing twentyone feeding at one time in the south arm of Yellowstone Lake. "I think it can be safely said," he wrote, "that there are I 500 moose living throughout the year in the valley of the upper Yellowstone, an area two to five miles wide and twenty long."

The moose's possible range is bounded on the north, as it is on the mountain-sides, only by the timber line. $\mathrm{He}$ is a creature of the forests-a "wood-eater," as the Indians called him-can subsist on the food afforded by a wide variety of trees, and loves the cold and thrives on it. The Kenai Peninsula in Alaska, famous for fine antlers, is in the latitude of southern Greenland.

Moose have never been found in the country between Hudson Bay and the Labrador coast, nor in Newfoundland. ${ }^{9}$ But, from southwestern

\section{${ }^{8}$ National Geographic Magazine, July, 1913.}

- Several Canadian moose were released in Newfoundland a dozen years ago, with a view to stocking the island. For several years they were lost to sight, and were supposed to have perished, but it has latcly been reported that cows and calves have been seen, indicating possible success of the experiment. 


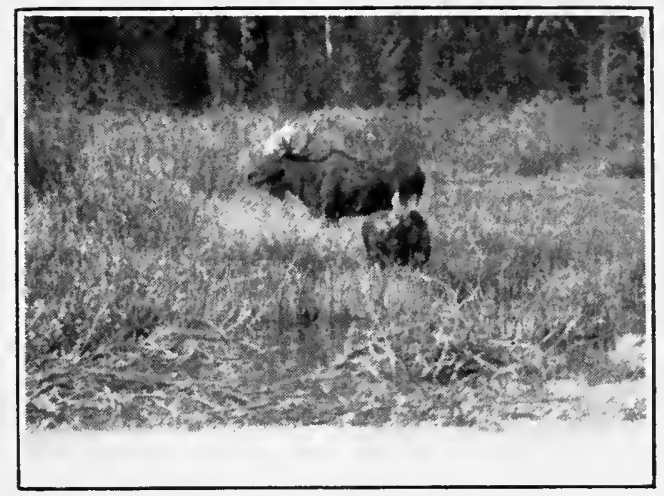

Bull and Calf on the Upper Yellowstone

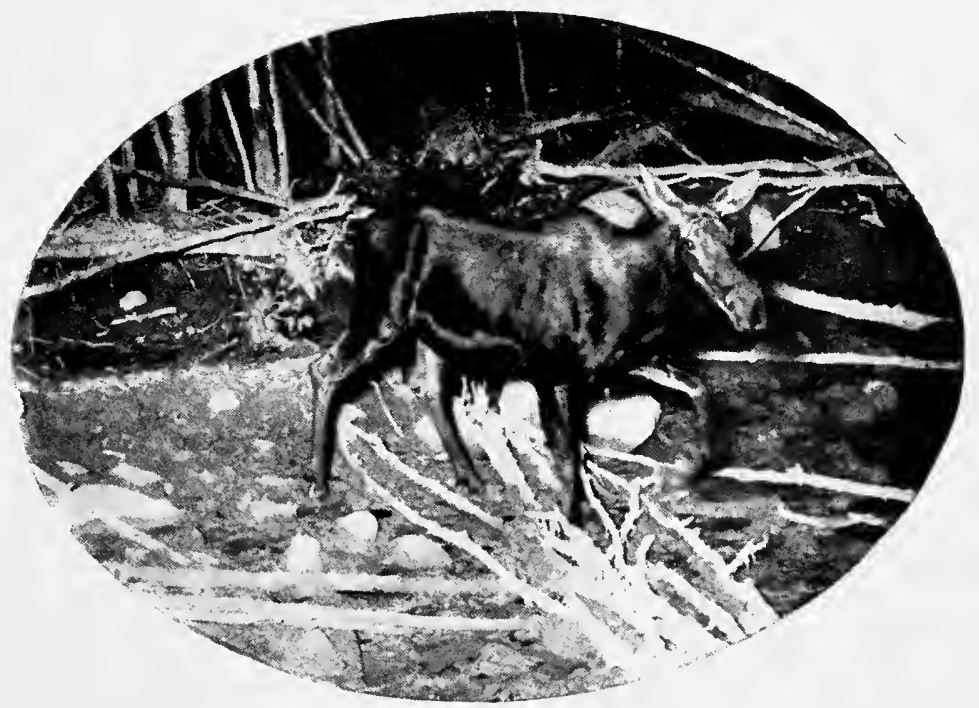

Cow Moose, at Natural Salt Lick, Lake Superior (Flashlight)

From Photographs by Hon. George Shiras, 3d 

Quebec, west and northwest to Bering Sea, avoiding the plains of southern Saskatchewan and Alberta, stretches an unbroken range, harboring great numbers of moose, numbers which can go on increasing since fate has decreed that Indians shall decrease. The territory gained by the moose in recent years has been chiefly in the Canadian Northwest, and in Alaska. Northern British Columbia, and the region lying farther north, as far as the delta of the Mackenzie, within the Arctic Circle, is all included in the moose's great domain. ${ }^{\text {1o }}$

The boundaries of this range, especially in the north, would, in a long series of years, show some minor changes, caused chiefly no doubt by fluctuation in the food supply. Insufficient forage, due to seasons of drouth, forest fires, and other causes, may induce a more or less general migration, but under favorable conditions the abandoned territory would be again occupied. Dr. Robert Bell, chief of the Canadian Geological Survey, in a

ro An excellent paper discussing the range of the moose is given by Madison Grant, secretary of the New York Zoological Society, in the Seventh Report of the N.Y. State Forest, Fish, and Game Commission, I901. The resources of Alaska with respect to moose and other game are described in the Year Book of the Department of Agriculture for 1907, pages 469-482, and by the same writer in the National Geographic Magazine for July, 1909. See also article by Geo.ge Shiras, $3 \mathrm{~d}$, in National Geographic Magazine, May, I9r2. 
paper read before the Geological Society of America, December 29, I897, discussing the migrations of northern mammals, says: "The moose or American elk (Alces americanus) migrates slowly from one large area to another through periods extending over many years. For example, in the Gaspé Peninsula the last interval between its leaving and again returning to the same district was upward of half a century, and in the region between the upper Great Lakes and James Bay the period between his last withdrawal and reappearance has been still longer."

Estimates of the number of moose occupying this vast area, extending from ocean to ocean, must of course be largely speculative. "The entire [American] range of the moose is about $3,500,000$ square miles," writes Ernest Thompson Seton. “. . . At a very rough estimate, we may put the number on the whole range at a round million of moose." ${ }^{2}$ Mr. Seton in making his estimate is quite safe from effective contradiction. If to these figures are added the number of elk credited to Siberia and northern Europe, ${ }^{13}$ the grand total-more than 3,000,000-would indicate that the race of Alces is not likely soon to perish from the earth.

× Bulletin of the Geological Society of America, vol. ix., p. 376 .

$\therefore$ Life Histories of Northern Animals (N. Y., 1909), vol. i., p. 155.

13 See pp. 29I-292. 



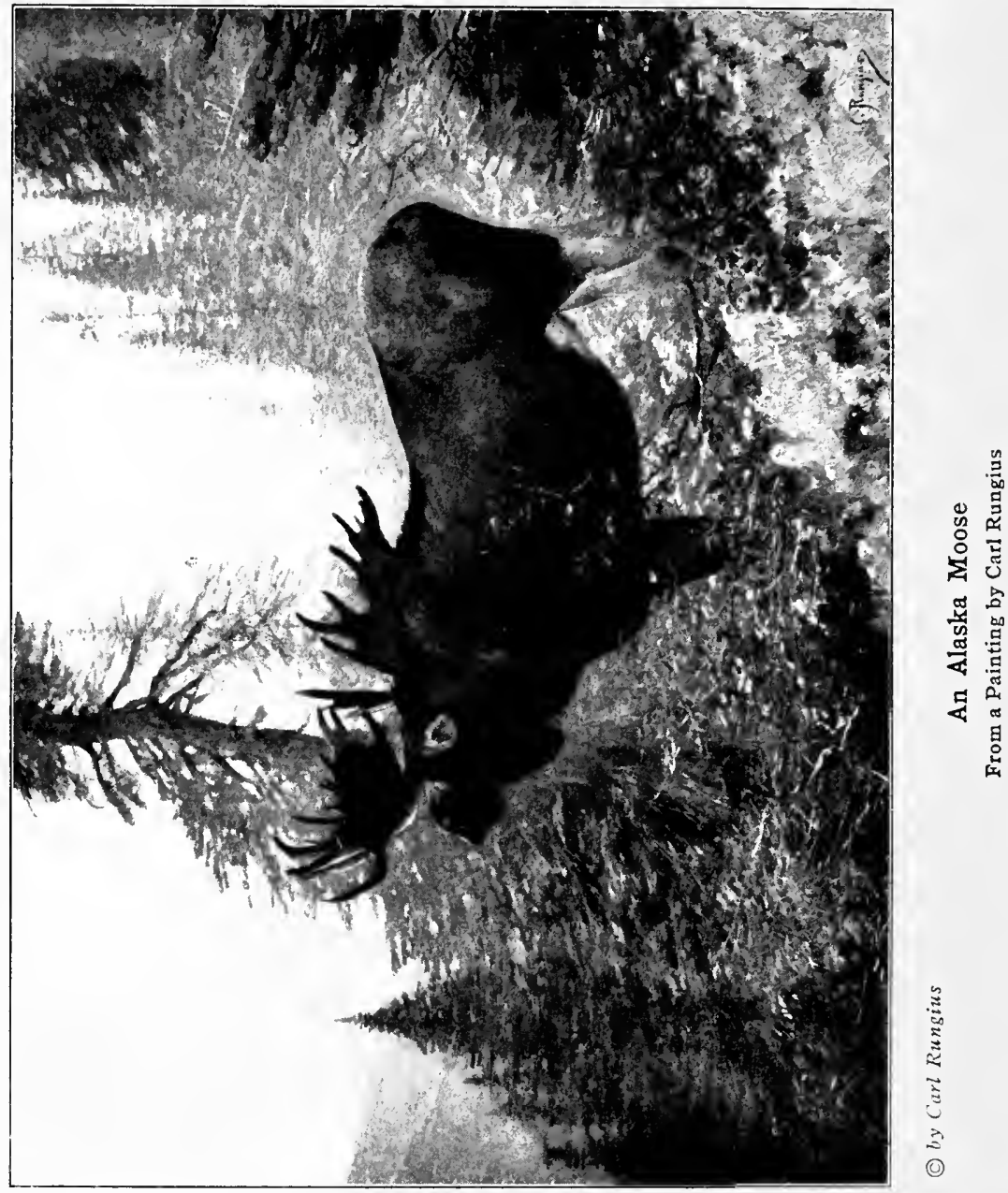


Game laws in the various portions of the moose's range are subject to frequent amendment. A summary of these laws in the several States and British Provinces, with regard to all classes of game, giving the provisions relating to hunting seasons, hunting licenses, bag limits, etc., is published annually by the United States Department of Agriculture, being compiled by the Bureau of Biological Survey. Copies of the pamphlet may be obtained from the Superintendent of Documents, Government Printing Office, Washington, the price being five cents each.

Facts obtained from official sources relating to the number of moose killed annually in the various portions of the moose's range, are given below. These returns are in all cases incomplete, many moose which are killed being consumed in lumber camps or in the smaller settlements, and no return being made to the game officials. In some cases the number killed in this way, and unreported, is very considerable.

Alaska.-Governor Strong of Alaska, in his annual report on the administration of the Alaska game law, dated November I, I915, says:

"The principal habitat of the moose in central Alaska is found on the Kenai Peninsula, but moose 
are also present in considerable numbers in the regions drained by the Yukon and Tanana Rivers and their tributaries. In the latter sections moose are probably decreasing in number, while the moose of the Kenai Peninsula are possibly slowly increasing, this condition being due to the possibility of stricter enforcement of the game law."

Quoting a report on game conditions on the Kenai Peninsula prepared by Special Game Warden L. F. Shaw, the Governor says:

"According to a native legend, a century ago there was not a moose to be found on the Kenai Peninsula. Then they appeared in numbers, coming from the Iliamna country [west of the peninsula], and gradually increasing from year to year until they were exceedingly numerous. Wolves, their most persistent natural enemy, and severe winters were about the chief factors in their destruction, as the peninsula was but sparsely settled.

"Then came the stampede for gold in the late nineties to the Cook Inlet country. The stampeders settled on the western side of the peninsula, founding the towns of Hope and Sunrise. At one time there were over 1000 people in the two settlements. The people depended for a meat supply almost wholly on the moose and 
mountain sheep, and there was a wanton and wasteful killing of these valuable food animals. Indeed, some of the old-timers made it their boast that they killed a moose merely for what they considered the choice part-the tongueleaving the carcass to go to waste....

"Now conditions are much improved. The game law, as applied to moose and mountain sheep, gives them immunity from needless slaughter, with the result that a gradual increase in their numbers is manifest. ..." "'

The area of the peninsula is about 9000 square miles.

In his report dated November I3, I9I9, covering the fiscal year ended June 30, I9I9, Governor Riggs gives estimates of the number of game animals of different species in various sections of Alaska. Moose "are found in practically all of the lowlands south of latitude $68^{\circ}$, and even north of this latitude in certain valleys," he writes.

On the Kenai Peninsula the number of moose is estimated at 4000 ; in the Fortymile District there are about I000; on the Nenana River 500; on Yentna River 500. In all these regions their numbers are increasing. On the breeding grounds about Lake Minchumina there are about I 500 moose, but they are suffering from disease, from 
the attacks of wolves, and from unlawful killing. To Ladue Creek, as far as White River, one estimate credits 20,000 moose, while another sets the number at 50,000. They are described as "plentiful," and as increasing, on the upper Tanana, at the forks of Kuskokwim River, and on Koyukuk River. They are plentiful, too, in certain districts in the valley of the Yukon. In less numbers they are found on the lower Kuskokwim and the upper Noatak and Kobuk Rivers (outside the range as represented on the map at page 32 ), and also on the Porcupine.

Only eight non-resident hunting licenses were issued during the year covered by the report. Residents of Alaska are not required to obtain licenses, and no returns are made which show the number of moose killed annually in the Territory. A special export fee of \$I 50 must be paid on each moose trophy, taken south of latitude $62^{\circ}$, which is shipped from the Territory.

The Alaska game law is subject to change by Congress. "Regulations," providing for special local restrictions, are frequently issued by the Department of Agriculture. Communications on the subject of hunting in Alaska should be addressed to the Governor of the Territory at Juneau. (See Appendix, page ${ }_{3} 6_{3}$.) 



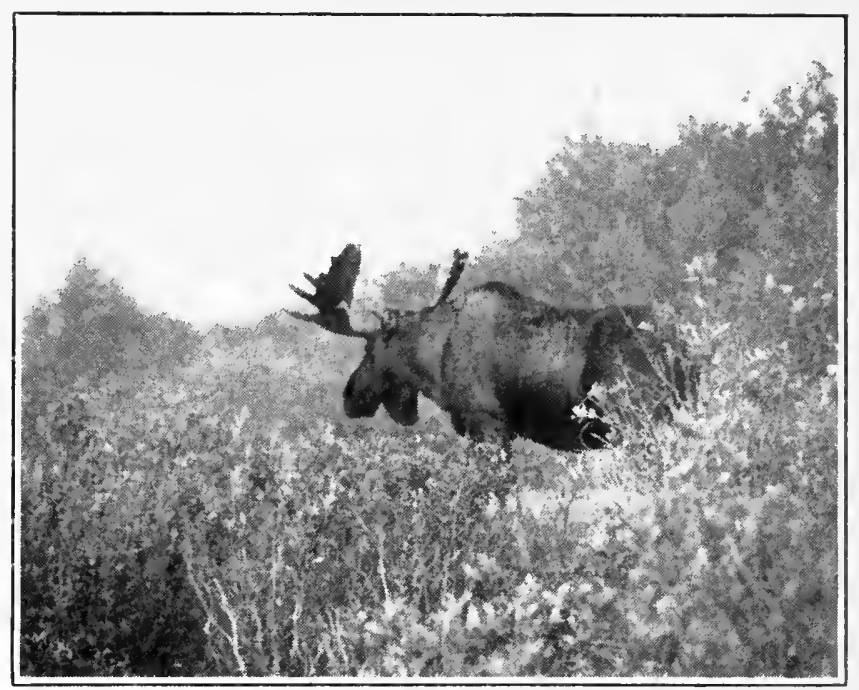

An Alberta Bull

From a Photograph by Carl Rungius

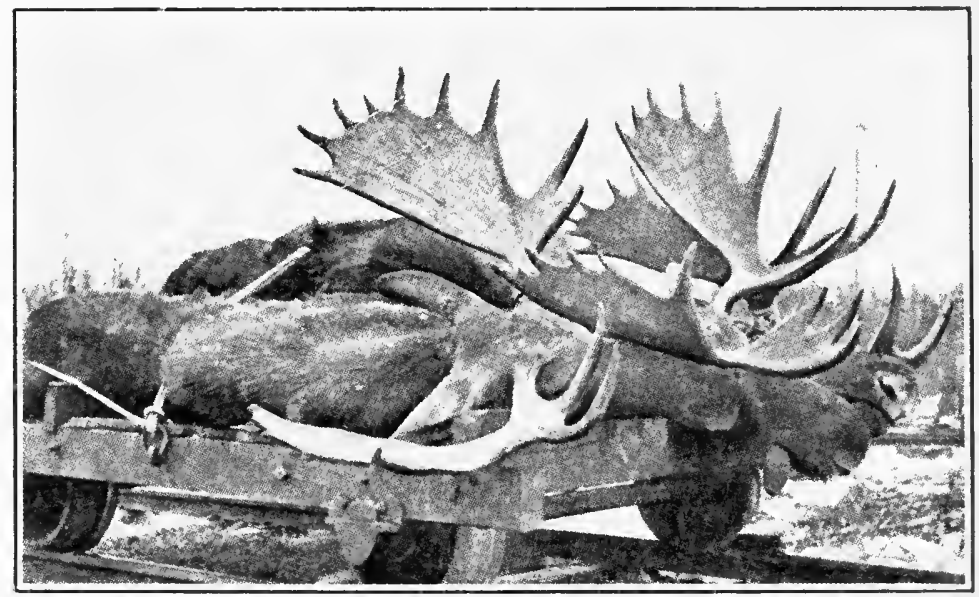

One Hunting Party's Bag of Moose

Lake County, Minnesota, 1918 
Alberta.-According to the last annual report of the Department of Agriculture, published in I9I9, the number of moose killed in the Province in I9I3, the last pre-war year, was 865 , while in the five years of the war the number averaged I045 a year. This number is greater than the aggregate yearly kill of Virginia deer, caribou, wapiti, mountain sheep, and mountain goat. Only twenty-four hunters in I918 held non-residents' licenses. The figures of game killed do not include moose taken in unorganized districts, north of the 55th parallel. (With respect to game refuges in Alberta, see Appendix, page 362.)

British Columbia. - Fifty-one non-resident hunting licenses were issued in 1918, against thirty-one in 1917. "Bag limits were obtained, with the exception of mountain goat, in almost every case by hunting parties." The kill by nonresident sportsmen in 19 I9 in the Cassiar District, where the best hunting is found, included sixteen moose. The best specimen had antlers spreading fifty-four inches, with blade fourteen inches wide, and having thirty points. No data are available showing the number of moose killed in British Columbia in any year. Many are destroyed 
wantonly by lawless Indians. (See Appendix, pages 362,364 .)

Maine.-There was no open season for hunting moose in Maine for four years, I915-1918. This closed season produced the desired effect, and in his report for 1918 the Commissioner of Inland Fisheries and Game stated: "That the moose are on the increase in the great game counties there can be no question, some localities claiming as many as ever before." The Legislature early in I9I9 provided for an open season for moose covering the last ten days of November. The number of non-resident deer-hunting licenses issued in Maine in 1919 was 2755, and of moosehunting licenses 104, but the total amount of game killed is not reported. The railroads of the State shipped 37 moose, and agents of one of themthe Maine Central-reported 57 moose killed but not shipped by common carrier.

Manitoba.-For several years past the war and other causes have greatly reduced the number of hunters, resident and non-resident, the number of hunting licenses issued in 1917 being less than half the number issued in I9I4. Seventeen big- 
game licenses were issued to non-residents in 1918 , but of these only three were taken by other than British subjects. The latest available report of the Chief Game Guardian states that the number of moose killed in the Province in 1917 was 1257 , while in 1918 the number killed was 1357 . Moose "are reported to be fairly plentiful in most of the districts of the Province congenial to their habits." (See Appendix, pages 362, 363.)

The laws of Manitoba and Saskatchewan require all holders of big-game hunting licenses to wear white clothing while hunting, as a safeguard against shooting accidents. The game officials state that such accidents have been very infrequent since these laws were enacted.

Minnesota.-About 175 moose were killed in this State in 1917, and 9000 deer. In 1918 the number of moose killed "would not exceed roo." The figures for 1919, based upon reports made by license-holders to the Game Commissioner, show about 300 moose killed in the State. "The deer killed will approximate 20,000." In I918 I 25 big-game hunting licenses were issued to nonresidents, at $\$ 25$ each. In I919, I8 I non-residents took out licenses, at $\$ 50$ each. (See Appendix, page 363. ) 
New Brunswick. - Only 194 non-residents hunted big game in 1918 ; in 1919 the number was 475 , more than 95 per cent of whom were from the United States. The kill of moose in 1918 was only 613, due in part to the fact that the sale of game meat was for the first time prohibited in the Province. The number of moose killed in 1919 was 1430. The average yearly kill for the five years ending in 1916 was 1546 . "I believe that moose are holding their own," writes the Chief Game Warden; accordingly it is not to be assumed that the reduced kill is due to scarcity of moose in the woods. (See Appendix, pages 362,364 .)

Northwest Territories.-This region comprises a vast area in the latitude of Alaska and southern Greenland. The white inhabitants number less than 20,000, in addition to whom there are 3700 Indians, and about an equal number of Eskimos. Moose are plentiful in the valley of the Mackenzie, as far as the western and southern shores of Great Bear Lake, and in the Great Slave Lake region. In less numbers they are found in the wooded valleys which extend even into the Barren Lands-the great treeless waste which includes the northeastern half of the Territories. Twenty- 
two non-residents were given hunting and trapping licenses for the Northwest Territories in I 9 I 8 .

Nova Scotia.-In I9I 8 the number of moose killed was 1243 . In 1914 a much larger number of hunters secured only 1095 moose. "The growth in the kill of moose from 405 in 1909 to 1363 in 1917," say the Game Commissioners in their report for 1918, "could not have been brought about unless the number of moose in the Province had considerably increased during the intervening years." Only twenty-three licenses were issued to non-residents in 1918, while in 1919 four times as many hunters came from outside the Province to engage in the sport.

Ontario.-Data gathered by the Game and Fisheries Department of Ontario with regard to the amount of game killed in the Province are very meager. The number of moose hunters' licenses issued in the fiscal year ending October 3I, I9I8, shows an increase of 516 over the previous year, but the number issued is not given in the report. The year ending in 1917 , in turn, showed a marked increase over 1915-16. In spite of the greater number of hunters, the report of the Deputy 
Minister of Game and Fisheries says: "Plenty of moose and deer are reported in that part of the Province lying north and west of the French and Mattawa Rivers [i.e., north of $46^{\circ}$ ], and generally satisfactory in the other parts of the Province which are inhabited by these animals." (See Appendix, pages 361-364.)

Quebec.-The number of licenses issued to non-residents in this Province in 1918 for huning big game was 5 I2. No data are gathered by the Provincial officials, however, to show the amount of game taken each year. (See Appendix, pages 362,364 .)

Saskatchewan.- "The moose is by far the most plentiful of our big-game animals," writes the Chief Game Guardian in his annual report for 1918. Prior to I9I 8 each licensed hunter was entitled to kill two moose in a season, but the baglimit was reduced that year to one bull moose. In 19I7, 226r big-game hunting licenses were issued; in 1918 the epidemic of influenza reduced the number of resident license-holders to 1788 , and of non-resident to three. The smaller number of hunters, the reduced bag-limit, and unfavorable weather conditions caused the number of 



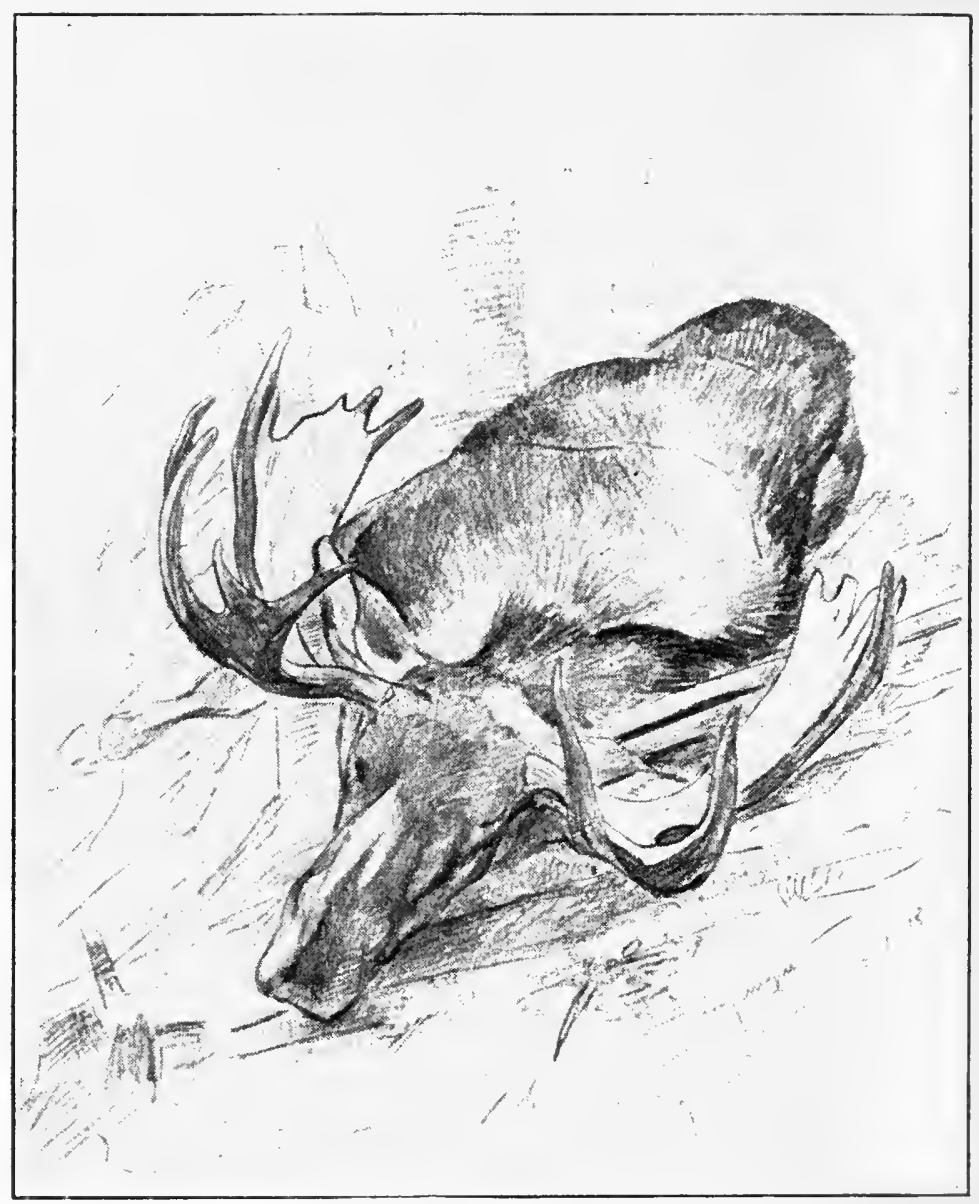

(C) by Carl Rungius

Fate of a Wyoming Bull

From a Sketch by Carl Rungius. (Head of Green River, 1898.) 
moose killed by sportsmen to fall that year from I 2 I 5 to 456 .

Wyoming.-Under a special legislative enactment, following twelve years of protection, sanction was given in 1915 for the issuance of licenses to kill fifty fully-matured bull moose during the hunting seasons of 1915 and I9I6. Under this act forty-six licenses were issued in the two years, at \$100 each, and the license-holders secured thirty-three moose. This hunting served a useful purpose in scattering the moose into new territory, thus extending their range, but further hunting was forbidden until I925. In his annual report for the year ending December 3I, I9I9, William T. Judkins, the State Game Warden, gives an estimate of the number of moose in the State. The figures are based on "counts and conservative estimates" contained in reports of State and Federal officials. Yellowstone National Park in this report is credited with 1600 moose (an increase from 50 since 1897 ), and the three northwestern counties of the State, near Yellowstone Park, have 2221. (See Appendix, pages 362,363 .)

Yukon Territory.-In a recent letter, the Territorial Secretary estimates that about 1000 moose are killed annually in Yukon, principally by 
prospectors, miners, and Indians, for whom the game of the country affords the chief meat supply. The population of the Territory is about 8500 , or one inhabitant to each twenty-four square miles. Twenty-three big-game hunting licenses were taken by non-residents in I9I9.

Certain features of the game laws are summarized below. A few unimportant local restrictions are omitted. In all portions of the moose range in America, females, and males under one year of age, are protected at all times.

\section{Open Season \\ (Dates Inclusive)}

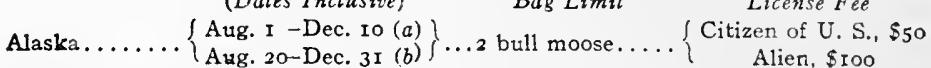

Alberta........ Nov, I-Dec. $14 \ldots \ldots \ldots$ I bull moose.....

Brit. Columbia.Sept. I-Dec. I5 (c) ...... I I bull moose.....

Maine........ Nov. 2I-Nov. 30....... I bull moose....

Manitoba. .... Nov. 20-Dec. Io... ..... I bull moose..... $\left\{\begin{array}{l}\$ 25 \\ \$\end{array}\right.$

Alien, $\$$ roo

$\$ 25$

$\$ 50(h)$

$\$ 25$

Minnesota ..... Nov. r5-Dec. 5....... r bull moose.... . \$50

New Brunswick.Sept. I5-Nov. 30....... I bull moose (g).. $\$ 50$

Northwest Ter. \} Sept. I-March $31 \ldots \ldots 2$ bull moose.... $\left\{\begin{array}{l}\$ 50 \\ \text {. }\end{array}\right.$

of Canada f Sept. I-March $31 \ldots \ldots 2$ bull moose..... British subject, $\$ 25$

Nova Scotia.. . Oct. I-Nov. 30........ I bull moose.... $\$ 30$

Ontario...... Oct. I-Nov. 30 (d)...... I bull moose.....

Quebec........ Sept. I-Dec. 3I $(e) \ldots$. . I bull moose..... $\$ 25$

Saskatchewan.. Nov. 15-Dec. I4 $(f) \ldots .$. . I bull moose..... $\$ 25$

Yukon........ Sept. I-Feb. $28-29 \ldots \ldots 2$ bull moose..... \$Ioo

(a) North of latitude $62^{\circ}$.

(b) South of latitude $62^{\circ}$.

(c) In Atlin, Cariboo, Columbia, Fort George, and Omineca electoral districts only.

(d) South of C. P. R. R. from Mattawa to Port Arthur, Oct. 5-Nov. 20.

(e) In Labelle, Ottawa, Pontiac, and Temiscaming Counties, Oct.I-Nov. 30.

(f) No open season south of line between townships 34 and 35 .

(g) Males under three years of age, and having less than three prongs four inches long on each horn, are protected.

(h) License fee $\$ 25$, plus $\$ 25$ for each moose, grizzly bear, sheep, wapiti, and caribou killed. 
In the geographic nomenclature of America the moose has left many evidences of his presence. The list of United States post-offices, however, includes only five in which the moose's name appears-Moosehead and Moose River, Maine; Mooseheart, Illinois, and Moose Lake and Moose Park, Minnesota.

In village names the moose appears frequently in various gazetteers and indexed maps. Thus Moose and Moose Island are villages in Minnesota, Moose Creek in Montana, Moose River in New York, and Moose Meadow in Connecticut. Moose River plantation is an unorganized township in Maine. Moose Lake is a railway station in Alaska under the shadow of the lofty volcanic peak of Mount Wrangell, and Moose Pass is a station on the Alaska Northern Railroad on the Kenai Peninsula.

Moose Factory is a trading post of the Hudson's Bay Company on James Bay, at the mouth of Moose River, Ontario. This was the ancient home of the Monsoni ("moose people"), an Algonquin tribe closely related to the Crees and Chippewas. They are also called the Moose and Moose River Indians. Their totem was the moose. Moosonee or Mosonee is the district on Hudson Bay from Moose River northwest to Nelson River. ${ }^{14}$

${ }^{4}$ Handbook of American Indians (Smithsonian Institution, 1910). 
Moose Brook, two Moose Rivers and Mooseland are villages in Nova Scotia, and Moose Park is in Quebec. Moose Creek and L'Orignal are villages in eastern Ontario, and Moosehorn is found in Manitoba. Moosejaw is a town in the great Moosejaw district of Saskatchewan. It is situated on Moosejaw Creek, so named because it is "where white man mended cart with jawbone of moose." Moosomin is a railroad station in Saskatchewan, whence stages run to the Moose Mountain country. Moosehide is an old Indian village on the Yukon, near the mouth of Klondike River.

Moosilauke Mountain is a picturesque landmark of northern New Hampshire. Two Moose Mountains and Moosehead Mountain are found in New York. There is a Moose Mountain also in New Hampshire, and Moosehorn Mountain in Vermont. New Brunswick has a Moose Mountain, while the Moose Hills and the Moose Woods are geographic features of Saskatchewan. Another Moose Mountain, 7960 feet high, is found in the edge of the Rocky Mountain range in southern Alberta.

Moosehead and Mooselucmaguntic ${ }^{15}$ Lakes are

I5 In Douglas-Lithgow's Dictionary of American-Indian Place and Proper Names in New England (Salem, I909), Mooselucmaguntic is defined as meaning "where the hunters watch the moose by night." Dr. Douglas-Lithgow gives meanings not associated with the moose to Moosilauke, and to one or two other names of Indian origin in which the syllable "Moos" is found. 
in Maine, and Moose Lake is in Minnesota. Two Moose Lakes are found in Alberta, and there are also lakes of this name in Nova Scotia, Manitoba, Saskatchewan, British Columbia, and Yukon. Two Moose Lakes and Moosewater Lake are in Ontario. Moose Rivers appear on the maps of Maine, New Hampshire, Vermont, New York, and Wisconsin, and twice in Minnesota. There are Moose Rivers also in Nova Scotia, Ontario, Saskatchewan, Alberta, British Columbia, and the Canadian Northwest Territories. Mooseleuk Stream is a tributary of the Aroostook, in Maine.

Government charts of the Maine coast show Moose Island, on which is situated the town of Eastport, close to the Canadian boundary, while Moose Cove is a dozen miles away. Farther west is Moose Peak light, guarding the western approach to Machias Bay, and near at hand are Moosabec Reach, Moose Neck, and a second Moose Island. Still farther west, close to the Mount Desert shore, a third Moose Island claims a place on the chart, opposite the mouth of Moosehorn Brook. There are Moose Islands too in Moosehead Lake and in Lake Winnipeg. Moosecajik, meaning "the moose's rump," was the ancient Indian name of Cape Rosier, in Penobscot Bay. Moose Deer Point is in Georgian Bay, Ontario. 
In a descending scale of importance other hills, ponds, and streams, named for the moose which frequented them, are scattered in the vast North Country, from the Atlantic to the Pacific. ${ }^{\text {r6 }}$ They are generally ignored by cartographers, but to the man who, rifle in hand, stalks the giant deer, they are often of more interest than the Himalayas and Congos of distant continents.

Division into Species.-The old-school naturalist was spared the puzzling questions incident to subdivision into species. A moose was a moose -and he would busy himself with building a fire to broil a slice of steak instead of tabulating dimensions with the aid of calipers while his stomach listened in vain for the dinner call. But with the discovery in America of the animal which some scientific men have called Alces americanus, arose the question whether he was of a different species from Alces palmatus or Alces machlis. In other words, is the American moose of a different species from the European elk?

One writer says that the moose of eastern America is "distinguished chiefly from its European

${ }^{2} 6 \mathrm{Dr}$. Stuckstates that in his travels in Alaska, in which he covered "ten thousand miles with a dog sled," he encountered thirteen streams which were known as Moose Creek. 


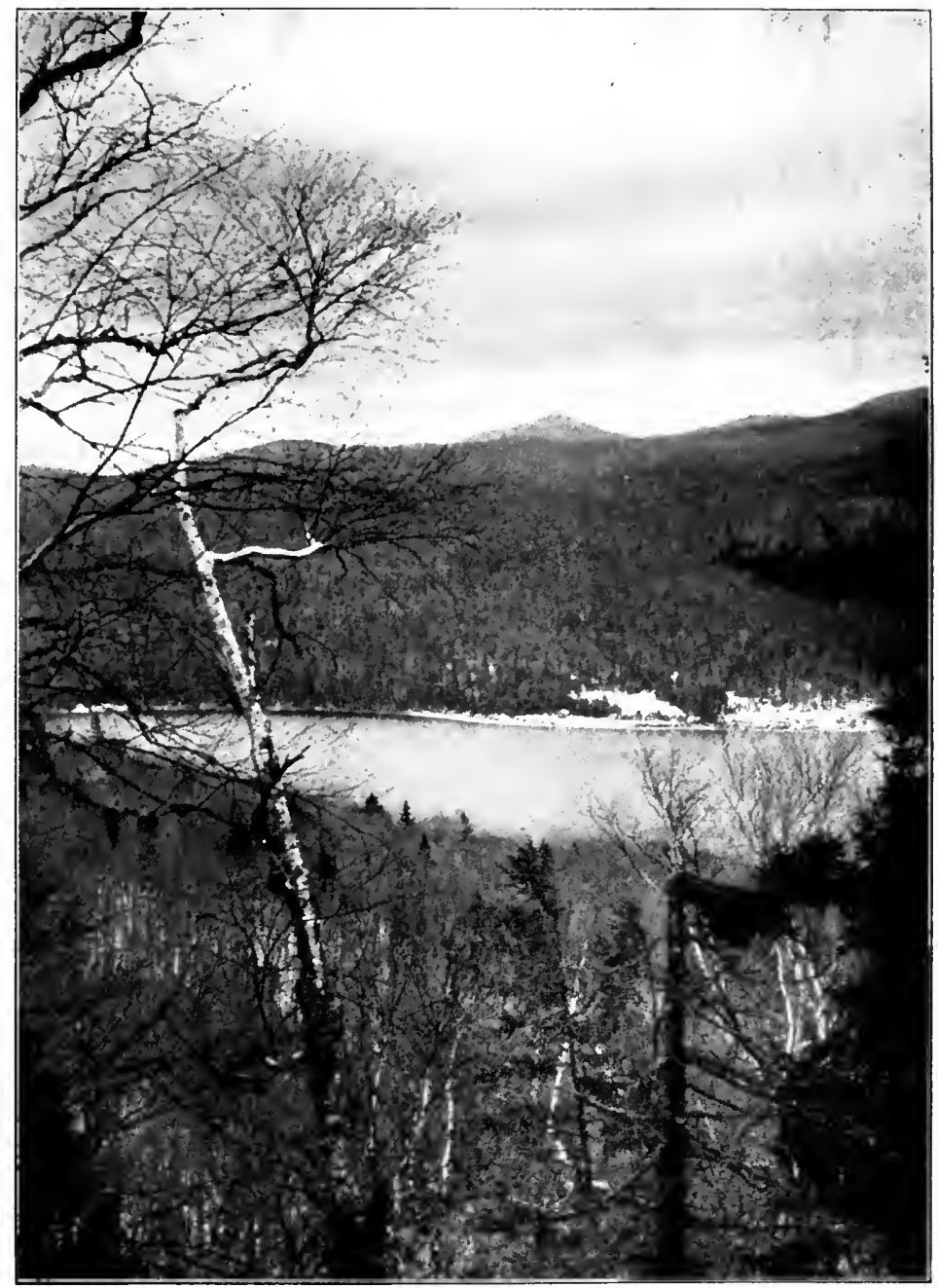

Mooseleuk Mountain, Maine, from Munsungan Lake 

congener by the skull being narrowed across the maxillaries, also by its greater size and darker color." But differences of size and color are often quite as manifest when comparing moose of New Brunswick and Nova Scotia. As for the maxillaries, if it is necessary to measure the breadth of jaw of two living wild moose for purpose of specific classification, few of us are fleet enough of foot, and brave enough, to obtain the necessary data. It would be interesting to know into how many species the human race would be divided if similar subdivision were attempted. John Jones, who is tall and dark-haired, with narrow jaw, would be likely to find himself in a different species from his brother Joseph, who, responding to some atavistic tendency, happens to be short and a blond, with the square jaw of an athlete.

Judge Caton, author of The Antelope and Deer of America, referring to the American moose and the 'elk of Scandinavia, wrote: "If one from either side of the Atlantic were transferred to the other, no one would suspect that he was an emigrant." ${ }^{17}$ Richard Lydekker, a high English authority, quotes with approval from Judge Caton, and adds: "It seems impossible to regard the Old World 17 A Summer in Norway, p. 327. 
and New World elks [moose] as even representing distinct sub-species." ${ }_{18}$

A Russian writer on Cervus alces, or Alces machlis, Baron von Kapherr, author of Das Elchwild, in an article in Die Jagd (Berlin), March 3, 1907, ridicules the efforts of zoölogists to subdivide the animal kingdom, and especially the Cervida, into a multiplicity of species. In a spirit of satire he differentiates between his black dachshund and his yellow dachshund, the former being in a species which he calls Canis domesticus subterraneus ater, and the latter being Canis domesticus taxus aureus. Incidentally he classifies zoölogists in a way not altogether complimentary to the "species" which delights in hair-splitting distinctions. In his judgment moose, whether found in Europe, Asia, or America, are no more to be separated into distinct species than are his two dachshunds. ${ }^{19}$

There are differences between the moose (or elk) in one territory and another by reason of different climatic or other conditions, especially in respect to food, or by reason of inbreeding or deterioration due to persistent hunting of the

${ }^{8}$ The Deer of All Lands (London, I898), p. 54.

19 Martenson reaches the same conclusion.-Der Elch (Riga, 1903), p. 5 . 
superior specimens. Similar differences, especially in the line of deterioration, are sometimes observed in the same territory after a lapse of years. These differences are often much more marked than the natural differences which are cited as the basis of subdivision into species.

Most recent writers state that there are two species of moose in America-Alces americanus and Alces gigas-but all fail to define the difference between the two species in a way which would enable anyone to distinguish between two specimens if living representatives of both species were met in the same enclosure. Specific differences will remain unimportant, in the judgment of most of us, so long as a post-mortem examination by an expert is needed to determine the correct classification of an individual animal. ${ }^{20}$

Gerrit S. Miller, Jr., of the Biological Survey at Washington, was the first to define the characteristics of Alces gigas, found in Alaska, as distinguished from Alces americanus, which inhabits the central and eastern portions of the continent. In a paper published in the Proceedings of the Biological Society of Washington, May

so "Every species should be distinguishable by external characters; and any animal which requires to be killed and dissected before it can be named, is of no practical value as an independent form."-Hornaday, American Natural History (N. Y., I9I4), vol. i., p. xxiv. 
29, 1899, he defines the general characteristics of Alces gigas as follows: "A larger, more richly colored animal than the eastern moose; skull with occipital portion narrower, palate broader, and mandible much heavier than in Alces americanus."

But Hornaday denies to the Alaska moose stature superior to the moose of New Brunswick, and as for the other dimensions, the Alaska moose is quite as disinclined to submit his skull for measurement as the moose in other ranges. ${ }^{2 r}$ Mr. Miller based his conclusions on the study of six specimens, four of which were males, secured in the summer of 1898 on the Kenai Peninsula by Dall De Weese for the United States National Museum. Whether the same specific differences would be found if a much larger number of specimens from Alaska were compared with an equal number from the Atlantic coast may be a matter of doubt.

It is believed that the antlers of the Alaska moose are of large size because of peculiar condi-

2: A new sub-species of moose from Wyoming is described in a leaflet of the Biological Society of Washington, published April 25, 1914. It is called Alces americanus shirasi, or Shiras moose, in honor of Hon. George Shiras, 3d, who explored the southeastern section of the Yellowstone National Park in the summers of 1908, I909, and 1910, and discovered great numbers of moose. The new sub-species is distinguished from the moose of Maine and castern Canada by lighter coloration and smaller hoofs, but cranial differences are not appreciable. 
tions with respect to feed, in the season when the horns are growing, ${ }^{22}$ and it is probable that a New Brunswick moose transferred to Alaska, or an Alaska moose carried to New Brunswick, would, within a year or two after his migration, be indistinguishable from the other moose about him.

Attention has been called by Madison Grant to a secondary palmation frequently noticeable in the antlers of Alaska moose. The brow prongs of fully developed antlers are usually connected by a web at right angles to the main palnation, while in the case of eastern moose such palmation between the brow prongs is much less noticeable. ${ }^{23}$ But this peculiarity in the antlers is not cited to support the claim that the Alaska moose is of a distinct species; furthermore, eastern moose not infrequently have an unmistakable secondary palmation of the same sort.

Zoölogists, in their disagreement on the general subject of subdivision into species, are arrayed in two camps. The advocate of a multiplicity of species contemptuously refers to the "lumper" who would include several of these minor sub-

22 "Apparently the Alaskan moose find in summer an abundant supply of some food which is particularly rich in horn-producing properties, and the enormous and freaky antlers are the result."-Hornaday, American Natural History (N. Y., 1914), vo!. ii., p. IIg.

${ }_{23}$ Seventh Report N. Y. State Forest, Fish, and Game Commission, I9or, p. 232. 
divisions in one well-defined species; and the advocate of a less number of species, each being marked by unmistakable characteristics, sneers at the "splitter," who would multiply species by ali sorts of trivial distinctions. In this situation the layman is pretty sure to be found on the side of the "lumper."

The scientific name given the moose by Linnæus was Cervus alces, and this designation was used by Buffon and Cuvier. Later zoologists, subdividing the genus Cervus, have given the name Alces to a new genus, the American representatives of which are Alces americanus and Alces gigas. The Old-World representative of this genus is called by European writers Alces machlis, Alces palmatus, or Alce alces. Meanwhile, the Cervus alces of the earlier writers still appears in many general works, including later pages of this book. To the unscientific sportsman thesc questions of nomenclature are naturally of little interest. 


\section{CHAPTER III}

\section{TRAITS AND HABITS OF THE MOOSE}

Civilized man, seeking a foothold in the wilderness, begins by destroying the forests. He must have room for his cornfields, and for his village. Thus the moose, dependent on the forest for subsistence, retreats before the advancing axmen, with their guns and dogs-leaving civilized man to study the moose through the medium of a specimen stuffed by some upholsterer, perhaps, and displayed in a museum. As a result a large measure of mystery has always surrounded the moose, and in popular estimation he has possessed a medley of contradictory attributes.

It is little more than a century since zoölogy was elevated to the rank of a science. And a century is too little time in which to correct all the errors which, through careless observation, had crept into the books in which the moose and his habits were described. Few even now possess the ability, and at the same time the opportunity, 
to make the exact observations which are needed as a basis for a complete description and life-history of an animal whose home is generally so remote from civilization.

Among many misstatements regarding the moose some of the most frequent concern his size. Many writers since Dr. Josselyn and Judge Dudley ${ }^{\mathrm{x}}$ have exaggerated, and not always, it is to be presumed, with intent to mislead their readers. A writer in The Big Game of North America, published in I890, tells of a monster Rocky Mountain moose. "As he lay on his brisket his withers were higher than any horse in the outfit. . . . He was fifteen hands high without his legs under him."

The distance, in a straight line, from the top of the shoulders to the brisket, or lower line of the breast, is commonly called the "depth of body." Andrew J. Stone, who is well-acquainted with the moose of Alaska, gives minute dimensions of three adult bulls taken on the Kenai Peninsula. The average depth of body of these moose is 33 inches, and the average height at the shoulders 77 inches. $^{3}$ If the Rocky Mountain bull "was fifteen hands high without his legs under him,"

See pp. 22, 24.

2 Page 24.

3 The Deer Family, p. 295. 



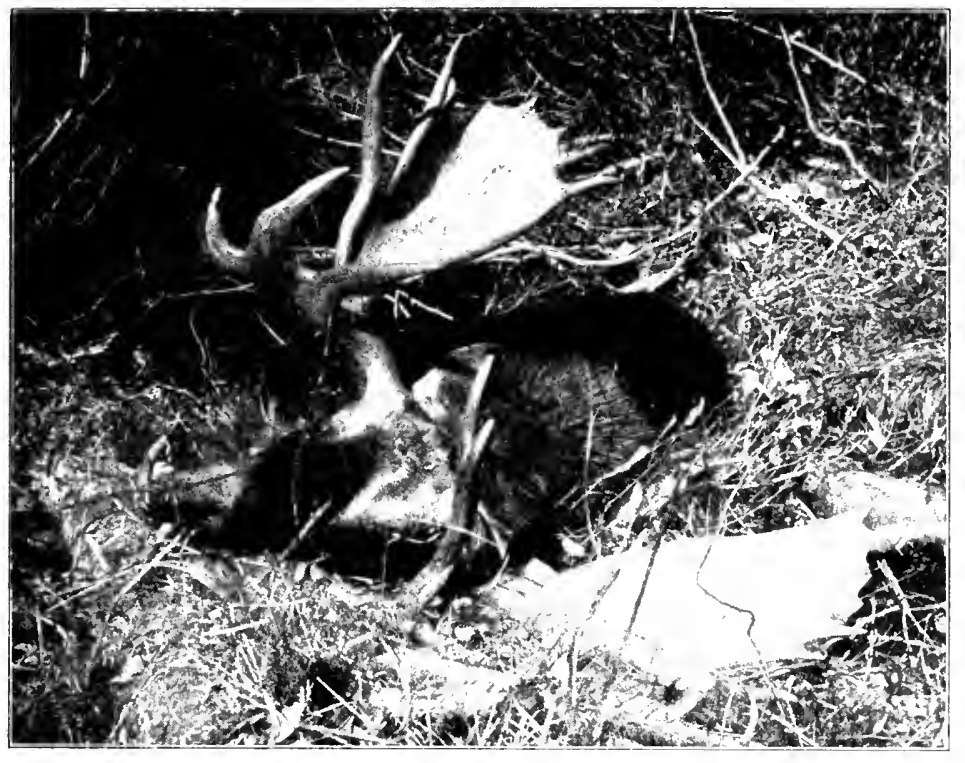

A 55-Inch New Brunswick Head

Shot by Carl Rungius

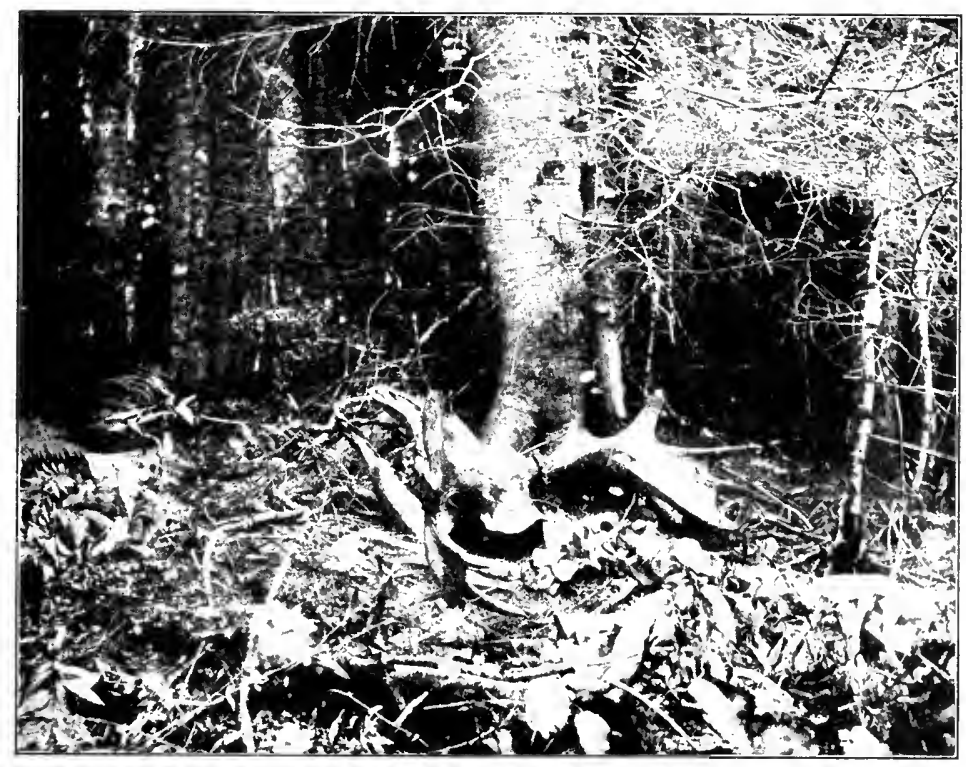

An Unrecorded Tragedy

Skeleton of Moose Found in the New Brunswick Woods 
his depth of body was sixty inches. And if his legs were as long in proportion as those of the moose on the Kenai Peninsula, his height at the shoulders was II feet and 8 inches. It is not worth while to dispute these dimensions. It would not be worth while, in fact, to mention this Rocky Mountain bull at all, save that foreign writers have quoted the description of the monster, without questioning the correctness of the dimensions given. ${ }^{4}$ The moose is a large animalthe largest of the deer family that ever lived-and it is quite unnecessary to exaggerate his stature.

A full-grown bull moose is six feet or more in height at the withers. Most measurements have been made, however, when the animal was lying on the ground. The position of the bones at the shoulder joint are not the same in death as in lifein the prone and the standing animal. The hoof of the prone moose is usually straightened out in a way which adds to the seeming stature; and many persons in measuring have included the long hair of the mane, giving the animal an altogether fictitious height. ${ }^{5}$

${ }_{4}$ See Big Game Shooting, by Clive Phillipps-Wolley (London, 1894), vol. i., p. 397 .

5 Frederick C. Selous, a prolific writer on African hunting, in his Recent Hunting Trips in British North America, writing of a moose killed in the Yukon mountains in 1904, says, at page 184, "I measured it carefully with a steel tape, and made its standing height at the withers 
The height at the shoulder should be measured in a straight line between perpendiculars when the animal is lying on the ground, one perpendicular being close to the skin at the shoulder, and the other at the bottom of the hoof when the leg is straight and the bottom of the hoof parallel with the body. ${ }^{6}$

A large moose is taller than the tallest horse, but the largest horse is much heavier than the heaviest moose. With long legs and short body the moose gains in height by comparison with the horse, without gaining in weight in proportion. The live weight of full-grown moose has seldom been ascertained. The dressed weight being known, it is easy to introduce a considerable

six feet and nine inches." The reader must wait till he reaches page 375 of Mr. Selous's book to learn that the measurement was made to "the extremity of the hair on the shoulder blade." The hair was doubtless from seven to nine inches long. Measurements of height, accordingly, must be accepted with some reserve in the absence of a specific statement regarding the manner in which the measurement was made.

${ }^{6}$ American Natural History (X. Y., 19I 4 ), vo!. i., p. xxx. A writer in the Century Magazine for January, I894, says, "In October, I880, George Ross killed in Muskoka [Ontario], a moose which, when carefully measured by several persons, stood eight feet two inches at the shoulders," but we are not informed how the measurement was made. It is well to have the aid of "several persons" if it is desired to establish a record. One or two can haul on the hoof while others, in a sort of tug of war, pull at the antlers. The distance between the point of the hoof and the ends of the hair of a long bristling mane in such a case ought to show some big figures. But the measurer should state how the dimension was ascertained. 
measure of error in making allowance for the entrails, blood, etc. Probably the average mature bull moose of New Brunswick or Maine weighs, when alive, less than one thousand pounds. One weighing twelve hundred pounds or more would be an exceptional specimen.

The largest Alaskan moose whose measurements are recorded by Hornaday was killed, and measured, by Dall DeWeese on the Kenai Peninsula. It was a bull, and the height at the shoulders was $803 / 4$ inches, the girth $913 / 4$ inches, and the length of head and body I $93 / 4$ inches. $^{\text {? }}$

In appearance the moose lacks the regal dignity of the American elk. He lacks also the show of spirit of the whitetail, which manifests itself in picturesque poses and graceful movements. But the intelligence of the moose is far superior to either. With large head, broad muzzle, prehensile lip, long ears, short and heavy neck, long legs, short body, high at the shoulders and low in the quarters-surely the moose can lay little claim to beauty.

${ }^{7}$ American Natural History (N. Y., 1914), vol. ii., p. 120. Mr. Hornaday mentions a moose killed in New Brunswick in I9or which measured 84 inches in height, but the gentleman who killed this moose informs me that, being inexperienced at the time, he measured along a curved line; accordingly, the measurement is to be disregarded. 
The hair is coarse and brittle, the color assuming various shades of brown, brownish black, and gray. Only the extremities are dark, the hair near the skin being white. Albino moose are unknown. The long hairs, or bristles, of the mane and throat are sometimes used by Indians for ornamenting moccasins; belts, pouches, and similar articles made of mooseskin or buckskin. The hairs are dyed in various colors, and are commonly employed in appliqué patterns, as porcupine quills and beads are used. From four to ten bristles are used together, according to the design, and they are stitched down with cotton thread. ${ }^{8}$ The hairs themselves are too brittle to be threaded into a needle and drawn through buckskin.

The "bell" is common to males and females. Its physiological purpose is unascertained. It usually shows its best development in young bulls, from ten to fifteen inches being the ordinary length. In an older specimen the bell would be shorter and wider, and a bull in his prime, with massive antlers, commonly has merely a wattle or dewlap in place of the bell. A cow moose is said to have been taken in Manitoba in 1903,

${ }^{8}$ See "Huron Moose-Hair Embroidery," by F. G. Speck, in American Anthropologist, Jan.-March, I9I I. 


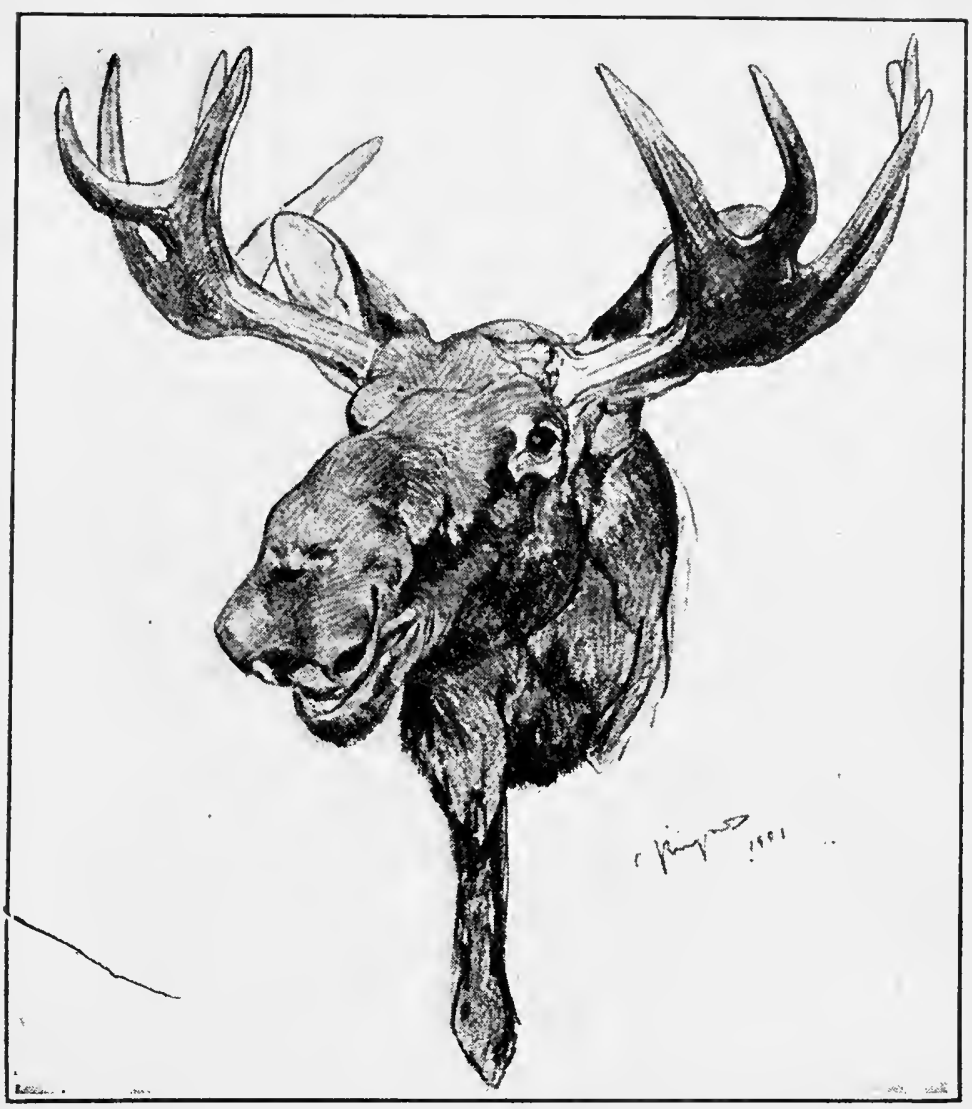

(C). by' Carl Runsisi

Antlers at Three or Four Years of Age

From a Drawing by Carl Rungius

Shcwing bell of unusual length. (Renous River, N. B.) 

having a bell thirty-eight inches long, exclusive of hair. ${ }^{9}$

The moose's tail is of insignificant proportions. Indeed, one old writer denied him the possession of any tail at all. ${ }^{\text {xo }}$ In a full-grown specimen the tail, exclusive of hair, will not exceed $4 / 2$ inches in length.

In intelligence the moose is superior to most other varieties of the deer family. But "a little knowledge is a dangerous thing," for moose as well as men. If in a given tract of ample dimensions there were fifty moose and fifty whitetail deer, and they were hunted with a view to extermination, the last moose would probably be killed long before the last of the whitetails fell a victim to the rifle ball. The reason is that the moose has a well-defined instinct, developed through the ages when his ancestors were pursued by carnivorous enemies, and has a certain definite motive for each measure of self-protection to which he resorts. The foolish whitetail knows no reason for seeking safety from pursuit by going " down the wind." The cautious moose learned ages ago that by this expedient he could escape the wolf-

${ }^{9}$ Life Histories of Northern Animals, vol. i., p. I63.

ro Pierre Boucher, IIistoire Véritable et Naturelle des Moeurs et des Productions du Pays de la Nouzelle France (1663). 
pack which might be following his track by the sense of smell. But man, cleverer than the moose, and more formidable than the wolf, thanks to his rifle, knows the devices to which the moose will resort-and governs himself accordingly. "Of all quadrupeds deer are the greatest fools," writes Hornaday. ${ }^{\text {II }}$ In his foolishness in many cases lies the safety of the whitetail, for no hunter knows what to expect him to do.

The moose's heaviness and lack of grace have sometimes given him the reputation of being stupid. But the moose belongs to one of the oldest families in the animal kingdom, and it is by intelligence rather than by stupidity that the family has been able to survive the changes of climate, the attacks of predatory animals, and all the other vicissitudes of the countless ages since the moose first appeared on the continent.

If a moose, suddenly confronted by a man with a rifle, stands for a few seconds to look toward the source of danger, it is not because of lack of intelligence. He seeks as best he can to ascertain the nature of the peril-if indeed there is cause for fear. His brief halt is to give time for his sensesof smell, of hearing, and of sight-to furnish him with a reason for adopting some particular course " American Natural History, vol. i., p. xxviii. 
of conduct. Most other species of deer would take refuge in unreflecting headlong flight, giving no thought to the nature of the peril that was left behind. And the moose's caution would involve no hazard if it were not for that unaccountable rifle. If the moose cannot fathom the mysteries of firearms he at least is no worse off than those sportsmen who, similarly deficient, are responsible for the shooting accidents of the hunting season.

A moose is easily tamed. If captured as a calf he shows little fear of men. He is playful and goodnatured when young, but bad temper shows itself later, during the rutting season, and in old moose the temper is likely to be uncertain at all seasons. In general the moose has been credited with a better disposition than most other species of deer. But deer of all species, including the moose, are more dangerous when domesticated than when wild, for the fear of man, which is man's safeguard in the woods, is then lost.

It is rare that moose have been successfully bred in captivity, nor do captive specimens of ten live long. Two moose were secured in Maine in I 895 for the Cincinnati Zoölogical Garden, and lived there in captivity nearly six years. They bred once in that time, but the calf lived only 
about four weeks. They were fed crushed oats, bran, fine sweet clover hay, and willow twigs. In winter they were always in good condition, but in summer they suffered greatly from the heat, and lost flesh. Cincinnati is just north of the 39th parallel. No other experiment in keeping moose in strict captivity in this country has ever been so successful. Usually the experiment ends in the death of the captive from gastro-enteritis, or inflammation of the stomach and intestines, in the second or third year. A German writer attributes the short life of moose in captivity in part to lack of the amount of tannin in their food to which they are accustomed. Moose also probably need more exercise than they usually get when in the ordinary game park of a city. ${ }^{12}$

The propagation of moose and deer in private preserves for commercial purposes is discussed in a bulletin of the Biological Survey of the Department of Agriculture, issued December 31, 1910. ${ }^{13}$ Experiments in this field have been chiefly with the wapiti and the Virginia deer, but the author of the bulletin states (p. is) that "perhaps no other

3 See pp. 307 et seq.

13 See also a paper by Frederic C. Walcott in Wild Life Conservation in Theory and Practice (New Haven, 1914), pp. 195-222. 
American deer is naturally so well adapted to domestication as the moose."

As the writer of the bulletin states (p. 52), "the chief obstacle to profitable game propagation in the United States lies in the restrictive character of State laws affecting the killing, sale, and transportation of game." In the interest of the game propagator a distinction should be made between wild game and game legally acquired and kept in private possession for commercial purposes or for private use. But "in more than half the States and Territories the sale of venison from private preserves is illegal at all times," and the owner at the same time is forbidden to use the venison for food in his own family. The tendency of recent legislation, however, is more favorable to the game propagator.

Disease is not known to have been a factor in reducing the numbers seriously in any portion of the moose's American range, but the elk of Europe suffer often from such ailments as malignant anthrax (milzbrand) and rinderpest. ${ }^{14}$ Doubtless moose living in close proximity to domestic cattle, however, as in Europe, are more exposed to epizoötic attacks than those in forests remote from civilization. The age which moose attain under ${ }^{44}$ See pp. 305-307. 
favorable conditions is believed to be eighteen or twenty years.

The moose rarely resorts to a running gait, unless charging an adversary. This may be because his shoulders are higher than his hindquarters. His usual gait is a rapid shambling trot. He does not jump like other deer, but, thanks to long legs, steps over obstructions which a whitetail would clear by a bound. A moose will sometimes escape without noise over ground where an Indian could hardly pass without being heard.

Moose have many times been driven to harness. For a short distance, on a good road, a good horse would prove the better traveler, but at the end of the fiftieth mile the horse would be hopelessly distanced. Snow of a depth which would offer great difficulty to a horse or to cattle does not greatly retard a moose, whose long legs are admirably adapted for travel on rough woods roads or in deep snow.

Prof. Spencer F. Baird of the Smithsonian Institution, in a paper on the domestication of deer, bison, etc., published in the report of the Commissioner of Patents for $185 \mathrm{I}^{15}$ says: "A gentleman near Houlton, Me., some years since 15 Part ii. (Agriculture), p. 115. 
trained a pair [of moose] to draw a sleigh, which they did with great steadiness and swiftness, subject, however, to the inconvenience that, when they once took it into their heads to cool themselves in a neighboring river or lake, no efforts could prevent them."

New Brunswick guides tell of a moose which was driven on the ice of the St. John River many years ago from Fredericton to St. John and return in a single day, the entire distance being 160 miles. He was warm but showed little evidence of fatigue at the end of the journey. His owner gave him the shelter of a stable the following night, with the result that the moose died. An animal which can survive a winter in the open air at the Arctic Circle needs no other stable than that which nature furnishes in every forest thicket.

While a moose is able to travel great distances in a short time, nevertheless, if undisturbed, and in a section where browse is plenty, he by choice will remain indefinitely in a relatively small area.

The moose is fond of the water. It is his refuge from the serious insect pests of summer, and there is an abundance of feed in the shallow bays. The moose swims well, but not rapidly. Like the caribou, his shoulders are well above the water when swimming. Stone relates how an Alaska bull 
moose two or three years old swam eight miles without showing evidence of exhaustion. ${ }^{16}$ Unlike the whitetail, a moose will not go on ice if he can avoid it.

In common with some other creatures of the woods, the moose has gained a reputation as a dangerous animal which his disposition does not justify. Attacks upon men made by moose are very rare, even in the rutting season. The occasional authenticated cases of such attacks are generally due, in all probability, to the moose in his passion mistaking his adversary for another moose. Wounded, and at close quarters, with all chance of escape cut off, a moose will of course attack a man as a measure of self defence: a squirrel would do as much.

The chief causes which have tended to give the moose a reputation for pugnacity have been the weaknesses and eccentricities incident to the rutting season, and his errors of judgment when confused by the glare of light from a jack carried by fire hunters in a canoe. ${ }^{17}$

In many camping trips in the moose country, seventeen of which have been made in the open season, when moose hunting was the chief subject

${ }^{16}$ The Deer Family, p. 318. 17 See pp. 146-I47. 
of conversation beside the evening fire, the author has sought to learn the experience of guides and sportsmen in this and similar matters. Once, years ago, on the head-waters of the Aroostook River, the after-supper subject of discussion was the moose as a dangerous antagonist of man. A number of guides and others took part in the conversation, but none had ever been attacked. William Atkins was, as usual, silent. Atkins had had more experience in moose hunting than anyone else in camp, so I sought to draw him out.

"How is it, William?" I asked. "What do you know about moose attacking men?"

"Well," drawled Atkins, "I expect I've been attacked by moose as many times as most anyone."

Atkins smoked busily for a minute or two, and we had to wait for the interesting details of his hair-breadth escapes. Meanwhile the smile which played around the corners of his mouth might mean most anything.

"Lots o' times;" said Atkins finally, "I've wished that the moose would get to chasin' after me, instead o' leavin' me to chase forever after them. But I've never yet seen a moose that wasn't mighty glad if he had a chance to run away. There's only one dangerous animal in the woods," 
he added. "That's a man with a gun which he don't know how to use."

This was an unusually long speech for Atkins to make, and he lapsed into silence again.

A remarkable instance of seeming hostility on the part of a moose toward men is related by Theodore Roosevelt in Scribner's Magazine for February, 19ı6. Mr. Roosevelt with two guides was hunting from a canoe on a lake in the Ste. Anne River country northwest of Quebec. On the morning of September 19, I9 5, he shot a bull with antlers spreading fifty-two inches. Late in the afternoon of the same day the party encountered another large bull on the same lake. The bag limit was one moose, so the men in the canoe paddled about, not far from shore, watching the moose, which in turn watched them.

"When we turned he followed us back, and thus went to and fro with us. Where the water was deep near shore, we pushed the canoe close in to him, and he promptly rushed down to the water's edge, shaking his head, and striking the earth with his fore hoofs. We shouted at him but with no effect... Altogether the huge black beast looked like a formidable customer, and was evidently in a most evil rage and bent on man-killing. For over an hour he thus kept 
us from the shore, running to meet us wherever we tried to go."

Finally the moose left, following a stream which flowed parallel with the portage trail which the party in the canoe must take to reach their camp. After waiting a few minutes the party landed and started up the trail.

"A couple of hundred yards on, the trail led to within a few yards of the little river. As we reached this point a smashing in the brush beyond the opposite bank caused us to wheel, and the great bull came headlong for us, while Arthur called to me to shoot. With a last hope of frightening him I fired over his head, without the slightest effect. At a slashing trot he crossed the river, shaking his head, his ears back, the hair on his withers bristling.

"'Tirez, m'sieu, tirez! vite, vite!" called Arthur; and when the bull was not thirty feet off I put a bullet into his chest, in the sticking point. It was a mortal wound and stopped him short. ...

"I do not believe that this vicious bull moose had ever seen a man. I have never heard of another moose acting with the same determination and perseverance in ferocious malice; it behaved, as I have said, like some of the rare 
vicious rogues among African elephants, buffaloes, and rhinoceroses."

An affidavit attesting the facts satisfied the Secretary of the Department of Colonization, Mines, and Fisheries at Quebec, and no official notice was taken of the technical breach of the game law.

Conflicting opinions regarding the pugnacity of moose in their relations with human beings may be reconciled if we consider that moose sometimes-but not often-experience a condition akin to insanity among men. The normal moose is harmless.

If there are more than three or four authenticated cases of men losing their lives in the woods as the result of being attacked by moose, the author has been unable to find them mentioned in the published literature relating to moose hunting, or in the stories told by woodsmen whom he has met. $\mathrm{He}$ is thus forced to the conclusion that the danger of attack is a negligible quantity. "The hunter has been injured much oftener by the common Virginia deer than by the moose. Near Fort Norman on the Mackenzie, a few years ago, a wounded bull charged and killed an Indian hunter who in his effort to escape was held by his clothing catching on a snag. Had the bull missed 



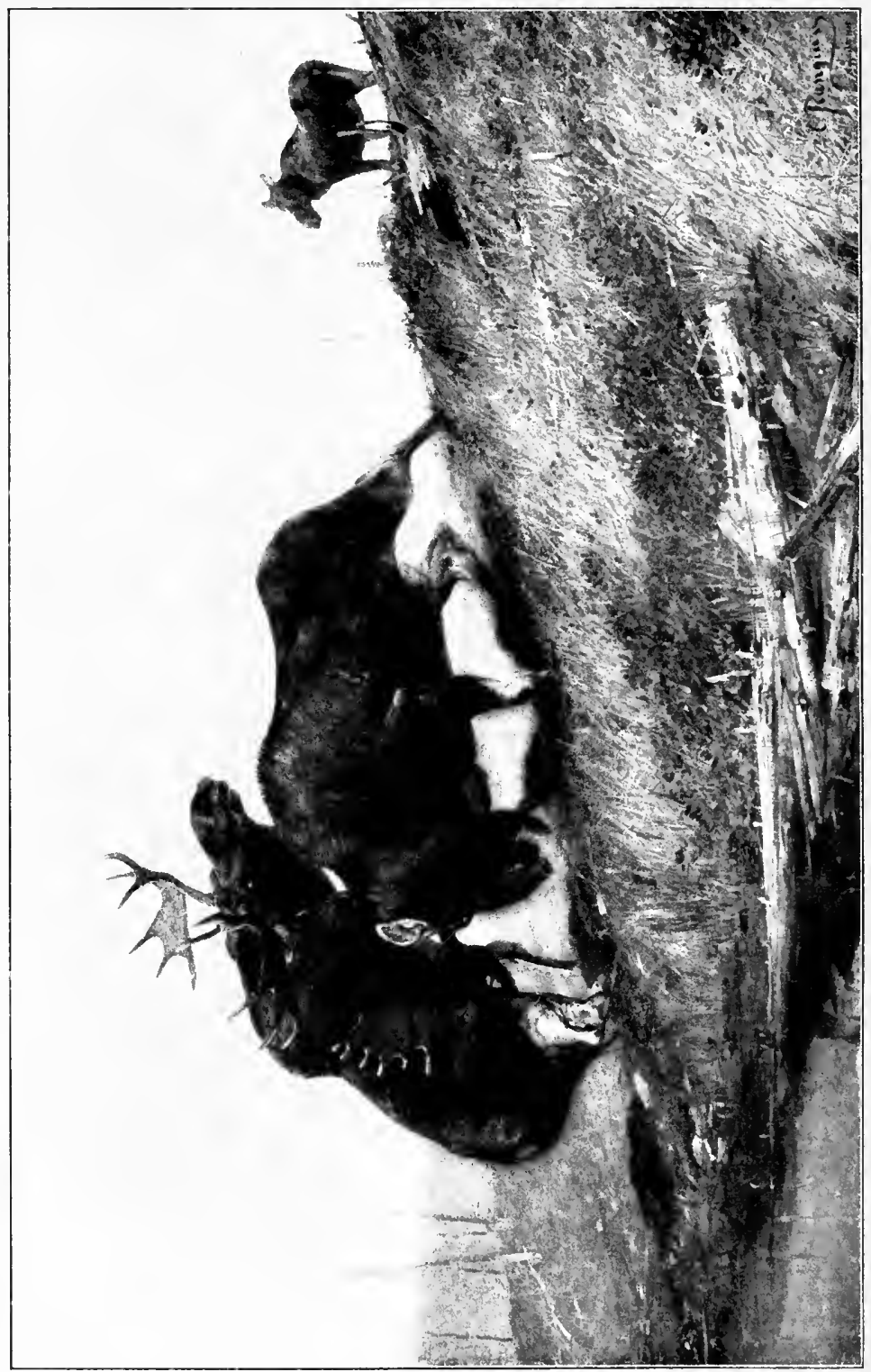

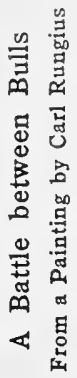


him in his first charge he would not have renewed it; few wild animals will return to a charge, failing in the first." ${ }^{18}$

Moose fight with others of their own kind only in the rutting season. At this season those of the fighting sex are equipped with antlers, and the antlers are the weapons for attack and defence in such contests. Against animals of other species the moose deems his hoofs his most effective weapons, but such battles are generally fought in seasons when horns are lacking. . Indeed, the moose rarely has occasion to fight, since in most of his range the wolf has been exterminated.

The growth of the antlers of the bull moose, ${ }^{19}$ and the brief season of mating, are physiologically closely associated. With antlers fully grown, the ${ }^{18}$ Andrew J. Stone in The Deer Family, p. 3I4. A writer in The Big Game of North America (Chicago, 1890), page 25, tells how a few years before a moose was attacked while swimming in Clear Water River in Idaho by a party of rivermen in a bateau. The men used axes, canthooks, and other implements of the woods as weapons of offense. The writer tells us that the boat contained six men and three tons of cargo. "The moose struck the boat with his antlers, and raised it clear out of the water, turning it upside down so quickly that the men were all frightened and stunned, and two of them were either killed or drowned." We are told that it was a large moose. A moose that can lift a bateau with six men and three tons of cargo by his antlers while swimming has to be large. But the moose of Idaho are not noted for excessive size, and this story, like that of the Rocky Mountain bull by the same writer (see p. 64), may be dismissed as the work of one who was careless with regard to facts.

'9 See Chap. vir., on "Heads and Horns." 
bull sets out to find a mate, manifesting a variety of emotions and qualities in his encounters with moose and men which are doubtless as little understood by himself as by any hunter who may chance to observe him.

Those who have written of the moose differ widely on the question whether moose are monogamous. If they were monogamous they would be alone in the deer family in this respect. An argument against the theory that moose are monogamous is the fact that in territory where the cows are protected, and the bulls freely killed, there is no undue proportion of barren cows.

Successful hunting in the calling season presupposes close study of the moose's habits, and especially his habits as affected by the mating instinct. Those who have observed the moose most minutely at this season generally agree that the male and female remain together; if undisturbed, a week or ten days. The female then no longer desires a mate, and the male seeks other companionship. The male thus may have several mates in the short season of the rut. If the bull is driven out by a hunter, or is a loser in a contest with another bull, he will leave the cow of his choice, and then will readily respond to the call of any unmated cow whose voice he may chance 
to hear. There is no reason whatever to suppose that the same pair will mate together for successive seasons.

Contests between bulls in the mating season are of frequent occurrence, and the skins of old bulls often show the scars of many such battles. ${ }^{20}$ If a cow is a spectator of a contest between two bulls which have come in response to her call, she is an indifferent one. Indeed, a cow has been known to accept the attentions of a crotch-horn bull while two older bulls were engaged in a frenzied combat to determine which should enjoy her companionship. Concerning the wallow, a small shallow excavation in the ground which is frequently observed in moose territory, opinions are at variance. Its chief characteristic is an evil odor caused by the urine which the moose deposit there. It is associated with the period of the rut, but is not, as some assume, a trysting place of the sexes. It is made by the male, but apparently not for the purpose of attracting the female.

A cow moose usually has one or two calves at a time-very rarely three. Most species of deer are less prolific. In the southern portion of the

${ }^{20}$ The effects of such a fight are described by Thomas Martindale in Hunting in the Upper Yukon (Philadelphia, I9I3), pp. I6I-I65. 
moose's range the calves are born late in April or early in May. Farther north the time is somewhat later. The birthplace of the ungainly little things is usually a densely wooded island, or other place which the mother deems safe from bears. If the birthplace is an island the grotesque youngsters may be seen, when still very young, swimming with their mother's aid. The calves boldly follow the mother into the water, and if distrustful of their own clumsy paddles support themselves by placing their fore hoofs on the mother's back, and thus convoyed make their way across broad reaches of water to the mainland.

Long loose-jointed legs, with short little body and high shoulders like a hunchback, give the calf moose an almost uncouth appearance. At six weeks of age he will weigh less than a hundred pounds, but will be as tall as a mature buck deer of the white-tail variety weighing two hundred and fifty pounds or more. The calf's neck is so short that he must kneel to touch the ground with his nose. His hair is woolly, of a sandy or light bay color, but as a yearling he assumes the blackish brown of adult life, the brown shading into yellowish gray on the legs and belly. The nose and upper lip are undeveloped in the calf.

The calf's growth is exceedingly rapid. Ac- 


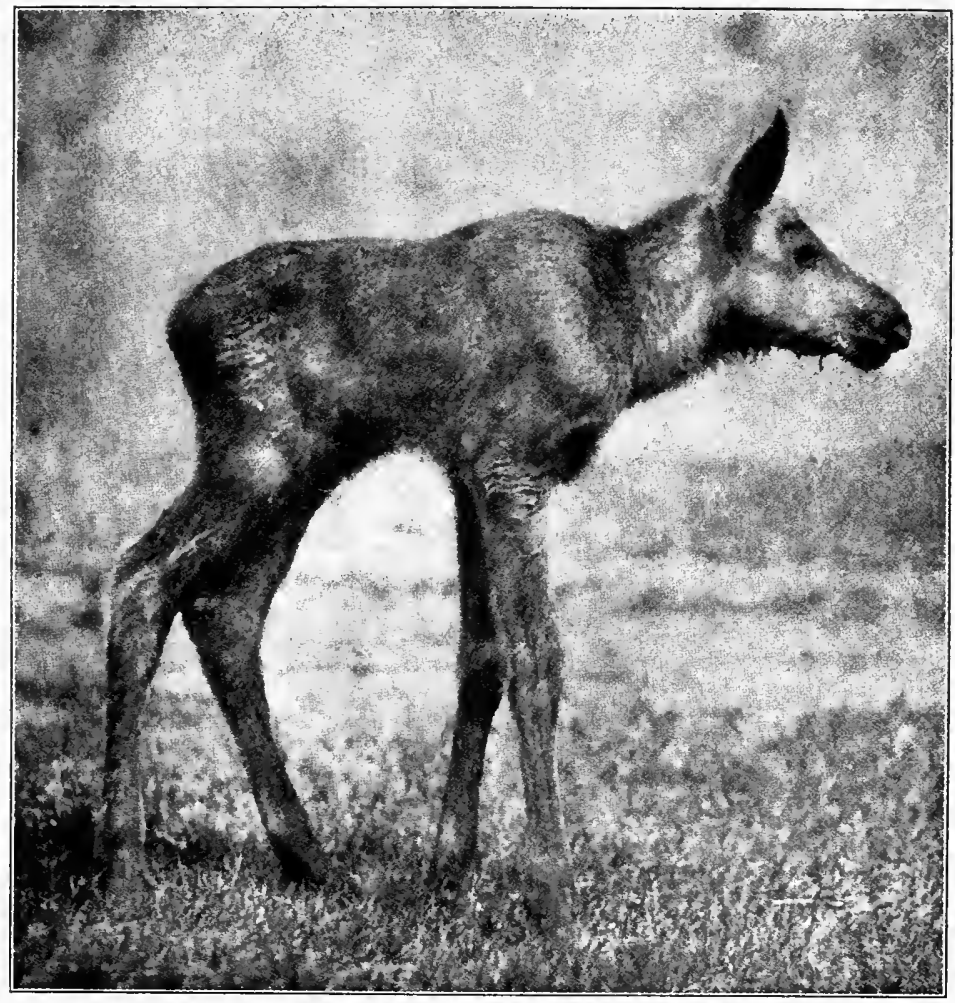

A Calf Moose (Age about One Week)

(Reproduced by Permission of Mr. Julian A. Dimock) 

cording to Andrew J. Stone ${ }^{2 \mathrm{I}}$ a calf a week old, weighing sixty-five pounds, will stand thirty-three inches high at the shoulders; the same calf at five months will be about sixty-seven inches high, and weigh six hundred pounds. But most moose at five months old are smaller than this.

Calves usually remain with their mother until their little half-brothers or half-sisters are born, and a yearling bull will often remain in the company of his mother-or not far away-even when she is with her new mate. As a crotch-horn, however, he would be driven away by the bull, if not by the cow herself.

The cow does not show the courage in defending her calf from apprehended attack with which she is credited. Calves manifest little or no fear of men, but of course will generally follow their mother in flight. Major Charles W. Hinman, who has a longer list of moose on his score of game killed than any other sportsman of my acquaintance, tells of capturing two calf moose in Nova Scotia and photographing them while the mother discreetly retreated to the shelter of the neighboring woods. It was on a meadow on the Shelburne River, May 17, I9r5, and the calves, a male and female, were no more than two days old. The "The Deer Family, p. 295. 
youngsters manifested no concern at being abandoned by their mother. The party in two canoes were in quest of trout. When the camera had done its work the men returned to their canoes and pushed off from shore, but the young moose followed into the water. Both showed some distress at being abandoned by their new-found friends, and one put his fore feet over the gunwale of one of the canoes in an effort to climb into it. The two calves were then taken back to the land, and carried by the guides some distance from the shore, where they were left, the guides returning at top speed to the canoes. As the canoes were paddled rapidly up the river the calves were seen making their way as fast as their feeble young legs would carry them toward the shore again, but the mother was nowhere in sight. Later in the day the party returned that way, but could find neither the cow nor calves. No doubt the little family, reunited, was safe in some friendly thicket. ${ }^{22}$

The moose is a ruminant, and is often seen standing listlessly chewing the cud. His dietary is more varied than that of most deer. It in1 2 See "How We Tamed Calf Moose," by Chauncey J. Hawkins, in Outing for November, I9ז. See also "Baby Moose," by A. W. Dimock, in Country Life in America for May, 1910. 


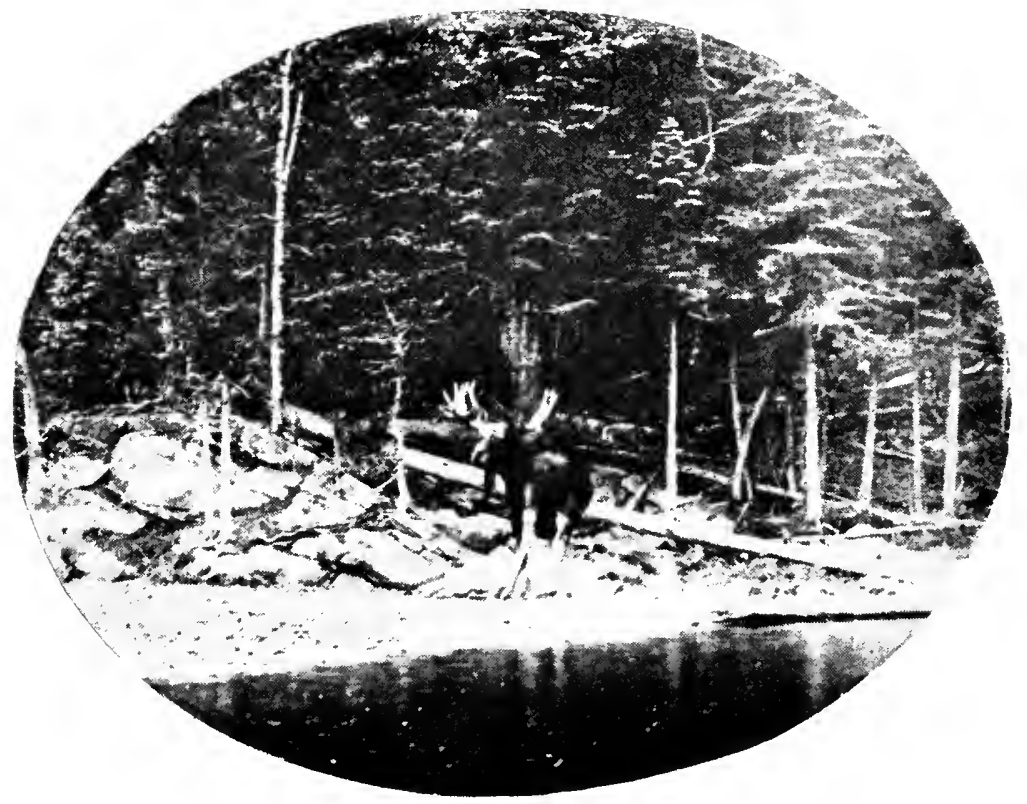

Bull Moose, St. Ignace Island, Ontario

From a Photograph by Hon. George Shiras, $3^{d}$

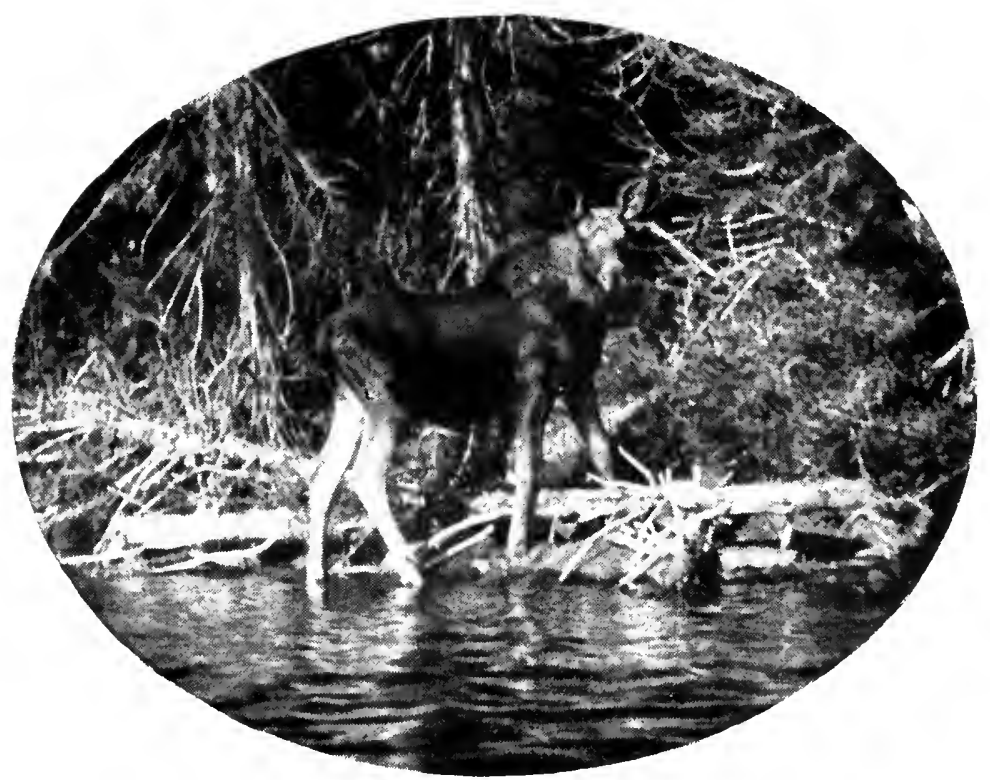

The Calf When Five Months Old

From a Photograp.l by Mrs. Anna B. Frank 

cludes the twigs, leaves, and occasionally the bark of a variety of maples, including the striped maple or moosewood. It includes also willow, birch, alder, poplar, mountain ash, and witch hazel. Moss and lichens too are on his menu, and in the summer the stems, roots, and pads of lilies and various other water plants. In the autumn and winter young spruces and ground hemlock are favored articles of diet, and the leaves and twigs of other coniferous trees. Burnt land, with one or two seasons' fresh growth of willows, is an especially popular feeding ground. Like all mammals, moose are fond of salt.

In table manners the moose shows little of the gentility of most of the deer. $\mathrm{He}$ of necessity straddles like a giraffe to reach moss or other browse which is close to the ground, and often rears on his hind legs to reach attractive morsels which cannot otherwise be nibbled from the limbs of trees. He frequently "rides down" saplings by walking over them, bringing the tender twigs at the top within easy reach. In good moose country hundreds of the smaller deciduous trees will be seen which have been "peeled," the moose by an upward movement of the head stripping off the bark with his chisel-like incisors. He peels only one side of 
a tree, with the result that the tree is not killed.

Like most of the ruminants, the moose has no front teeth in the upper jaw. In addition to the eight sharp-edged incisors in the lower jaw, the moose has a battery of molars which would serve as a model for a pulp mill. These molars easily

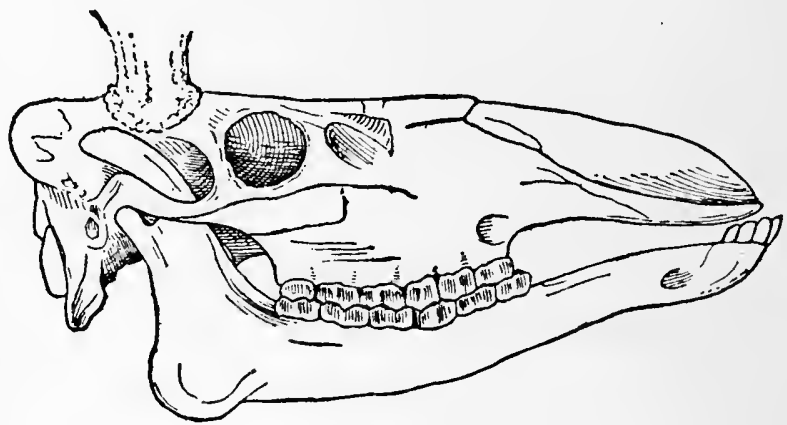

Skull of a Moose

grind up twigs as thick as a man's finger. The milk teeth in the single line of incisors are narrower and more pointed than the permanent ones. They are gradually replaced, those in the center of the row being the first to give way.

Little attention has been paid by American naturalists to the subject of the moose's teeth. The author, like most sportsmen, has had scant opportunity to study the teeth of cows, or immature bulls, and the published works on zoölogy 
give little information concerning the time when the milk teeth make way for the permanent ones in any of the moose family. Professor Nitsche of the Academy of Forestry at Tharand, Saxony, says that the milk teeth of the moose and other Cervide are replaced much earlier than in the case of the Bovida. The incisors of the male calf, he says, are replaced "at the time of the growth of the first antlers, accordingly at the age of from eight to twelve months; the molars are replaced at the time of the second antlers, or at the age of fifteen or sixteen months." ${ }_{23}$ The author cannot believe, however, that the full set of permanent teeth is attained at so early an age. In old age the incisors are gradually lost, thus increasing the difficulties of subsistence.

There is little difference between the night and the day in the routine of a moose's life. He travels and feeds at night as well as by day; he lies down to rest by day as well as by night. He usually browses until an hour or two before midday, and then for two or three hours is likely to lie down and chew the cud of idle contemplation. As he is more on his guard when resting the hunter should increase his own caution in proportion.

${ }_{3}$ A. Martenson, Der Elch (Riga, 1903), p. 8. 
Wild animals often appear to be practically color blind. The creatures of the woods seem to pay little more attention to a scarlet coat, such as some apprehensive woodsmen wear, than to one of more subdued color. Thus a flaming garment may be a partial safeguard against the reckless hunter who is inclined to shoot at every moving thing which he sees, while the same garment, if its wearer is standing still, will arouse no especial suspicion on the part of the moose. It has been remarked that wild animals recognize danger only in life, and life only in motion. A man standing still in the woods, in plain view, even if dressed in conspicuous culors, will often be disregarded by moose, provided the wind does not carry the scent of the man in the direction of the animal. A slight movement on the man's part, however, will tell the moose that he is in danger.

The sense of sight in all the deer family is obtuse and uncertain. In this respect man is altogether superior to most animals.

On one occasion in Nova Scotia we were on our way to a calling stand a mile and a half from camp, and were crossing one of the broad barrens which are the chief characteristic of the moose territory of Canada's "Province in the sea." We had traveled a mile or more, laden with packs contain- 
ing a canvas lean-to, blankets, extra clothing, and provisions for a supper and breakfast. When in the middle of the barren we noticed two moose standing in the edge of the sparse timber which fringed the broad open bog. We had no glass, but the guide, with younger eyes than his employer, was sure he saw antlers on both heads.

It was a long shot. I had killed a dozen moose before that, but had perhaps never fired at one at much more than half this distance. It seemed to be more than four hundred yards. I had targetted my rifle at various measured ranges up to three hundred yards, so I threw off my pack and raised the rear sight to the three hundred yards' mark. The wide expanse of hardhack and low white alders which covered the bog would hide the moose from view if I tried a knee rest, so standing up and aiming from the shoulder, but holding for_a point just over the moose's back, I pulled the trigger. Both animals at once started, and ran toward us. It seemed a strange maneuver on their part. They came diagonally about fifty yards nearer, and stopped. I fired again, at the same one as before, but they stood rigid. A third shot, aiming high as before, caused my moose to make a convulsive movement, which told me that I had scored a hit. He ran back, soon stopping 
and looking in our direction, while his companion took another course, but keeping for some time in view. My moose made one or two short runs, and finally disappeared in the thicket and scattered timber which formed the background of the picture.

The sun would set in another half hour. It was slow work crossing the bog and the sluggish stream which lay between us and the trail of the wounded moose, and it was still slower work tracking on the bare ground by the aid of scattered drops of blood. The trail of blood led us half or three-quarters of a mile. The moon, which was nearly full, contributed more light than the sun, which was already below the horizon, when we finally came upon my moose lying down. $\mathrm{He}$ got upon his feet, but only to receive the coup de grâce. The previous shot had hit low in the hind-quarters, but he had suffered no broken bones.

We discussed that unexpected movement, when, after the first shot, the two animals ran toward us, and agreed that their dim eyesight had shown them merely two unidentified figures, moving on the open bog. They stood at attention, looking toward the dark moving objects, when the first bullet probably struck a rock behind them, toward 
the edge of the timber. The noise of the unexpected blow on the rock near at hand no doubt seemed to them a more imminent peril than the report of the rifle far off on the barren, and they ran from the nearer danger.

The subsequent shots, and the crippling sting in the hind-quarters, told one moose that danger was abroad on the barren, and the retreat of the wounded bull told his companion that it was time to seek a change of scene. Probably neither moose could see the dark objects on the bog with sufficient distinctness to identify them as the chief enemies of their race, but Judson Gray, expert moose hunter and caller, with the eyes of a man in his prime, could easily see the antlers on the heads of the moose. It seemed to me to be a clear demonstration of the inferiority of the moose's vision.

The moose's superiority in his sense of smell and hearing, much more than offsets his deficiency of vision. Sometimes the moose's ability to scent danger and escape it is surprising. In other cases he shows a degree of indifference to the scent and sight of man that is inexplicable. It has been said that this occasional indifference is met only in sections where moose and men have been 
close neighbors. But George Shiras, $3 \mathrm{~d},{ }^{24}$ relates instances of the moose's disregard of men in the Kenai Peninsula more striking than any ever observed by the author in Eastern Canada and Maine.

Mr. Shiras tells how he photographed an old cow at a mud-hole much frequented by the moose.

"Determined to try for a close picture, and to test her disposition when thus interrupted, I boldly walked in view, crossing the bare and much-trampled field to within fifty feet. She stood broadside, head up, and unquestionably looking at me out of one eye, but to all appearances utterly indifferent to my approach. Taking a picture, I went a little closer, when she turned away without looking, and again the camera recorded the scene.

"While changing plate-holders, I was surprised to see the moose turn about and come toward me on a slow trot. To the uninitiated this would probably have meant a bold charge, and to the nature faker sufficient grounds for an exciting story. . . . Wishing to avoid alarming her so soon, I backed across the field to the edge of the marsh, but she still followed. Turning my back to the animal, I walked ahead, and upon reaching a place

"4 National Geographic Magazine, May, 1912, pp. 447, 449. 
where the ground was almost impassable with fallen timber, I stopped. . . . The cow immediately came up, circled almost within reach, and then was struck by the scent. The effect was instantaneous and remarkable. ... With a quick awkward plunge, she made off at her fastest gait."

F. C. Selous, in his Recent Hunting Trips in British North America, tells of still-hunting in the snow in the Yukon Mountains "where in all probability the foot of a white man had never trodden before." "I stood literally within ten paces of the sleeping moose," he writes. A bullet in the neck gave the Englishman a fine fat moose with antlers spreading $581 / 2$ inches. ${ }^{25}$

On another occasion, two years later, in the East Yukon country, firing at a large bull from a rocking canoe he made a miss. The distance was less than thirty yards. "He stood perfectly still, right in the open ground, and broadside on, with his head turned toward us. . . . But the moose never moved a muscle until my second shot struck him... Then he turned slowly round and walked toward the forest behind him." Mr. Selous was using a single-shot rifle. Two more bullets ended the hunt. ${ }^{26}$

25 Pages 16,182 . The moose was shot September 8, I904.

${ }^{26}$ Ubi supra, p. 37 r. 
Paul Niedieck gives the details of a moose hunt near Tustumena Lake, on the Kenai Peninsula, in October, 1906. There had been no hunting in that region for three years, he said. On the day in question, after seeing more than a dozen moose, and hearing others, he finally shot a bull. "When the moose fell," he writes, "the woods became alive about me. From all sides the moose came forward-some twenty in all. They stood and looked at me, each one wishing to satisfy his curiosity. A cow came directly toward me, as if she wished to avenge her mate, and would not leave until my guide threw sticks at her. I was busy removing the antlers, which had a spread of 65 inches, when a smaller full-grown bull came on the scene. He gave me time to put a fresh film in my camera, and I was able then to photograph him several times." ${ }^{27}$

Andrew J. Stone refers somewhat disparagingly to Maine as affording opportunity for "a parlor moose hunt." ${ }^{28}$ And Madison Grant writes: "It is difficult for a hunter whose experience is limited to Maine or the maritime provinces, to appreciate how very shy and wary a moose can be." ${ }_{29}$ But

27 Kreuzfahrten im Beringmeer (Berlin, 1907), p. 216.

28 The Deer Family, p. 323.

${ }^{29}$ Seventh Report N. Y. State Forest, Fish, and Game Commission, 1901, p. 230. 
the author, with considerable experience in hunting moose in Maine and the maritime provinces, has never found moose so nearly "halter-broke" as those described by Mr. Shiras, Mr. Selous, and Mr。 Niedieck.

Deep snow, crusted, leaves the moose comparatively helpless in the presence of wolves, cougars, and men. At no other season need a full-grown moose fear any animal which seeks his prey without the aid of firearms.

When the snow becomes deep moose gather in "yards." The little community usually consists of from three to half a dozen animals, mostly young bulls, cows, and calves. The old bulls are inclined to keep by themselves. The yarding place is chosen where feed is plenty, and a network of paths admits of considerable movement within a limited area. When the feed is exhausted in this area a path is broken to some neighboring thicket, and so, by an occasional short migration, the food problem is easily solved. If a season's snowfall chances to be light, the moose do not yard at all, yarding seeming to be dictated solely by an instinct which thus provides protection for the weaker animals, at the season when escape from danger by flight is impossible. With the 
melting of the snow in spring the little herd disperses, the cows, with the calves, seeking a quiet retreat where the calves of the next generation may be born in safety.

In Nova Scotia the moose rarely find the snow in winter much more than knee-deep. Consequently they do not remain in restricted yards, but are frequently seen crossing the open snowcovered barrens, seeking the sweet fern, which is a favorite article of their food. In the remote Northwest, too, contrary to common supposition, the snowfall is much less than in the woods of Maine and New Brunswick, and the moose move about with nearly as great freedom in winter as in the spring and autumn. ${ }^{30}$

30 See article by Tappan Adney, "Moose-Hunting with the Tro-chutin," in IIarper's Magazine for March, I900. Mr. Adney gives an interesting account of a winter moose-hunting trip with a large party of Klondike Indians. The hunt lasted three months, and yielded about eighty moose. 



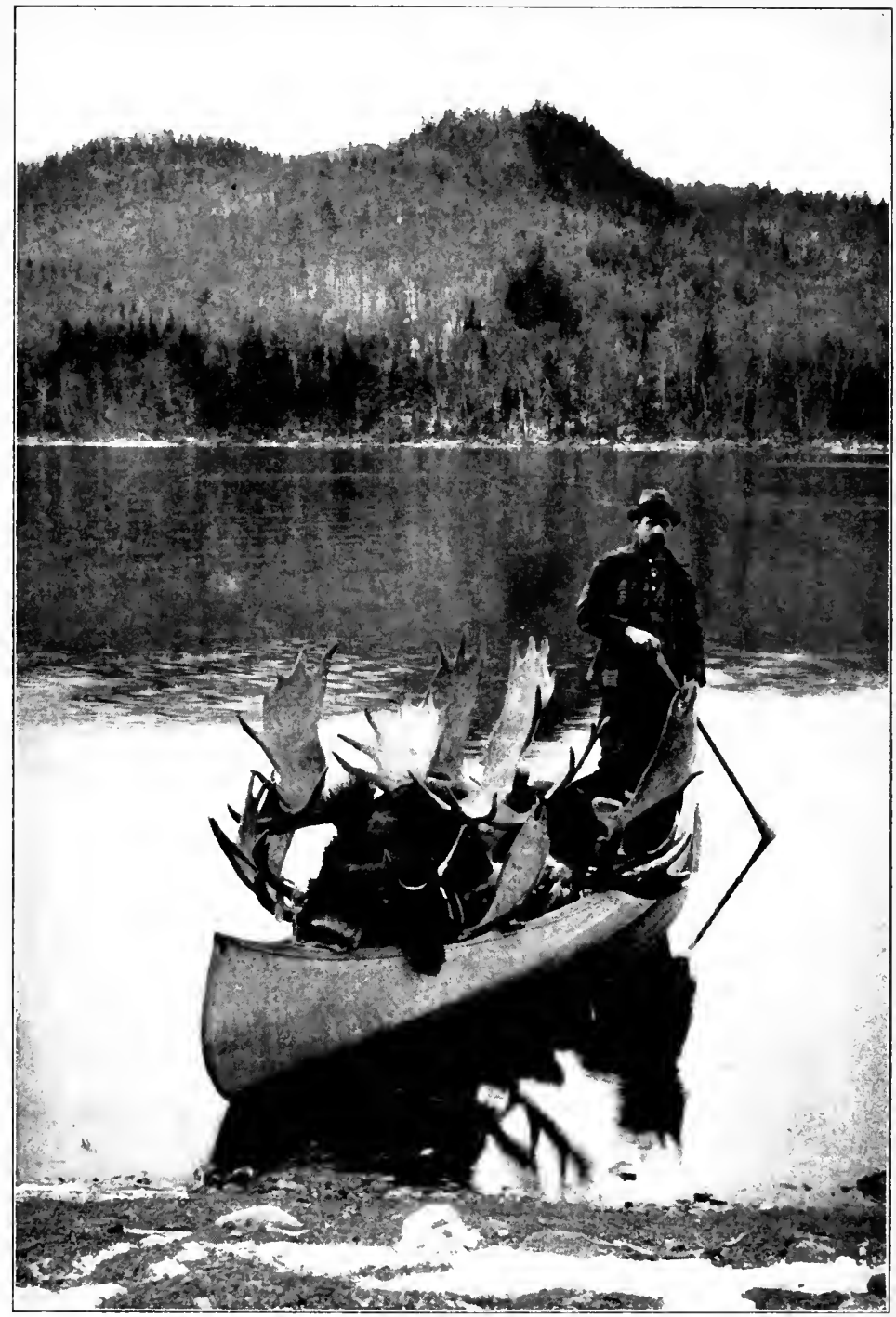

November in the Moose Woods 


\section{CHAPTER IV}

\section{STILL-HUNTING}

Still-hunting, or "stalking," as it is often called, is the commonest present-day method of hunting the moose. It is perhaps the only method which always and everywhere-if moose hunting is permitted at all-measures up to every standard of sportsmanship, and falls under no legal ban.

The strategy of still-hunting is in many respects the same whether one is seeking moose or other large game. An experienced hunter of the smaller species of deer is likely, however, to fail signally if he seeks the moose in a section where moose are few and wary, unless he has familiarity with the moose's habits, and can read aright the special "signs" which are relied upon to lead one within gunshot of he coveted head. For the purposes of the present work the writer will assume that the reader is familiar with deer hunting in general, for it is rare that one sets out in quest of moose 
without first serving an apprenticeship as a hunter of the whitetail or similar game.

Through uncounted centuries the instinct of the moose was developed with a view to selfpreservation. The moose of today possesses this instinct, the inheritance of his race, and it would be adequate to enable him to cope with the cougar and the wolf and his other traditional enemies which are commonly called predatory. But the most terrible animal of all is a late comer-and he brought the rifle. Moose tactics furnish safeguards against creatures which stealthily follow their intended victims by the aid of a powerful sense of smell. But this late comer, who lacks keenness of scent, often remains invisible, and from a distance strikes a mortal blow. The inheritance of instinct, alas, furnishes no safeguard against the invisible bullet.

The art of still-hunting consists in taking advantage of man's superior reasoning power, his superior eyesight, and the inventive skill which gives him the rifle, to bring to bag the animals which could easily outwit or outfight their fellow wild animals which fight with teeth and claws. If still-hunting is more sportsmanlike than calling or jacking or dogging, it is because in still-hunting man at his best is pitted against the moose at his best, and 
the result is never a foregone conclusion. Stillhunting is possible at all seasons, and in the pursuit of all species of deer. Calling is effective for a limited season; it is effective only when the moose is thrown off his guard by the violence of his passions. Successful still-hunting presupposes a considerable degree of alertness and skill in woodcraft, on the part of sportsman and guide alike. Calling, it has been said, presupposes experience and vocal skill on the part of a guide, and little but patience on the part of his employer.

A good still-hunter possesses the gift of exact observation in a high degree. Book knowledge will never serve as a substitute: it may aid in giving direction to the powers of personal observation, but it can do little more. And besides the power of close observation, the still-hunter must possess vigilance, unremitting vigilance.

A sportsman and a guide once followed a moose track for three or four hours in two feet of soft snow. There were no snowshoes within fifteen miles. Snowshoes would have been of little assistance in any event, for they would have sunk deep in the light dry snow, but walking without them was slow and tedious. Furthermore, moose were few and very worldly-wise. 
As a result, if one found a track whose freshness gave any sort of promise, he was inclined to make the most of it.

When first seen the track was nearly two days old. The hoof-prints were not those of a moose which would break any records, but it was almost the end of the season, and it would not do to be too particular. After two hours or so the track was much fresher, for several round beds in the snow had been passed where the animal had lain to rest and ruminate. The timber was open hardwood, and while the track seemed to be that of a bull, the evidence was not conclusive, and the desired evidence that a good pair of antlers was waiting at the other end of the track was entirely lacking.

Dinner time came, with the convenient brook for water. The dinner pack disclosed some slices of venison steak and a small frypan-an unusual utensil under the circumstances.

"I guess we are booked for a cold lunch," remarked the hunter, having in mind the comparatively fresh moose works.

"O, he's three hours ahead of us!" said the guide. "We may as well have some hot tea and steak."

While the guide was coaxing a fire out of two or 
three handfuls of dry sticks the sportsman went down to the brook to fill the tea pail, and he agreed that the track of the moose where it crossed was several hours old.

Dinner caused a delay of thirty minutes perhaps, and the men resumed the trail across the little brook. ... I am not at liberty to print what the guide said when he had gone thirty yards or so up the other bank. Not that it was confidential-it was merely unprintable. For that track three or four hours old was crossed by another hardly an hour old, showing that the moose had made one of his frequent loops, and, crossing his own track, had lain down for a noonday siesta less than a hundred yards from where the miserable fire of the dinner camp had sent out its notice to everything in the neighboring woods that men were abroad. There was the bed in the snow, and there were the long strides of the frightened fugitive leading from it. But we never saw that moose.

Eternal vigilance is the price of moose steak. We didn't pay the price, and we didn't get the steak. The guide's attempt at consolation by concluding that it was only a cow moose, after all, reminded me merely of the fox's opinion that the inaccessible grapes were not sweet enough to eat 
anyway, without lightening the burden of a homeward journey empty-handed.

In addition to vigilance, persistence and some measure of physical endurance are needed by the still-hunter. Since the mountain will not come to Mahomet, Mahomet must perforce journey to the mountain. Occasionally one stumbles on a fine moose and gets a shot without the long patient search, but this is a rarc exception to the general rule.

One sunny afternoon in early October I was idling about a Nova Scotia camp. I was giving little thought to moose, for my hunt had ended successfully three days before. In front of the camp stood a wagon on which my moose was loaded; in the rear the oxen which were to draw the load to the settlement were peacefully eating their supper. A young man named Lovitt, who lived in Yarmouth, and his guide, Clarence Gray, were making us a visit. Lovitt had been hunting unsuccessfully for ten days or so, making his headquarters at a camp five or six miles below us.

I chanced to be on the platform before the camp when I heard a commotion inside. Lovitt had sprung to his feet and seized his rifle, and was rushing to the open window. I stepped to the 
end of the platform to see what was causing the excitement, and looking around the corner of the cabin saw a large moose facing me twentyfive yards away. At that instant Lovitt's rifle cracked, and two or three seconds later he was on the ground outside. After firing, seeing the moose retreat, he stepped from a chair to the top of the dining table, and then plunged through the window, his shoulders breaking the casing above the opening as he threw himself in great excitement into the open air. Two more shots were fired and the moose fell dead sixty-eight yards from the cabin.

The moose was old and battle-scarred. $\mathrm{He}$ bore antlers spreading 49 inches, and having I I 7 points. This moose had approached the camp from the leeward-perhaps in flight before a younger and more vigorous antagonist. The odors of the oxen and the smoke from the camp stove had had no deterring effect. It was Lovitt's first moose. In a lifetime of hunting he may. never get another with so little effort.

A windy or rainy day is favorable for stillhunting moose, because the sound of a stick breaking under the hunter's foot will then be less noticeable. Wet leaves, furthermore, will not 
rustle under the feet as dry ones will. Moose lie down often for an hour or two, and always lie down at midday. They are more watchful when lying down than when traveling or feeding. At midday, accordingly, especial watchfulness is incumbent on the hunter.

The track of a moose is like that of a domestic cow, but larger, and somewhat more pointed. The means by which the freshness of a track may be determined are various. In this respect there is no material difference between tracking moose and tracking the smaller species of deer. It is necessary to take notice of atmospheric conditions. Aided by knowledge of a recent shower, or flurry of snow, or the effect of freezing, one can judge how much time has elapsed since the animal which made the track passed that way. On bare ground a track made two hours ago generally looks very much like one that is only ten minutes old, but this is not the case when hunting on snow. Snow freshly turned up has a sparkle which is soon lost by disintegration of the crystals at the surface. The experienced tracker always seeks by a comprehensive view to see a long series of footprints at once, and thus keep the general direction in which they lead, rather than to waste time by looking in succession at the individual footprints close at hand. 
With some study one can learn to distinguish between freshly nibbled twigs, and twigs which were cropped several hours earlier, by the color and moisture of the exposed inner bark and the wood. Similarly the freshness of the peeling of bark on the trunks of trees may be judged. But most hunters rely less on such signs than on those pertaining to the tracks of the animal.

Two men can hunt more effectively together than one alone, if they are equally painstaking. A guide, leading the way and studying the tracks, the evidences of browsing, and the many other things which demand attention, may easily frighten the animal which made the tracks, if the animal chances to be a hundred yards away and looking along his back track as he feeds. But the sportsman following the guide, if he keeps a sharp lookout for a possible quick shot, paying little attention to the tracks, is ready with his rifle for just such an exigency.

Where a sportsman has a little experience, and enters thoroughly into the spirit of the hunt, it is probable that he will see the game that he is seeking before his guide sees it twice out of three times. This is no disparagement of the guide. In the division of activity as above outlined it is to be expected. 
Moose show fear of the tracks of men only when the tracks are fresh, and still hold the human scent. In snow the scent quickly disappears, but on bare ground, in warm weather, it will remain for hours. A number of times I have observed fresh moose tracks leading to the track of a man made an hour or two earlier, and then following alongside the human track without crossing, as if it were a barrier to be dreaded. Sometimes the moose had followed alongside for some rods, and then jumped across and fled, running as if he thought the tracks could chase him.

The size of the moose is fairly indicated by the size of his footprint, but the spread or quality of his antlers cannot be so easily estimated. Body and hoof increase a little in size after a bull passes his prime, while the antlers deteriorate in old age. The length of the stride in walking, and the height at which the moose can reach browse on the trees, are other indications of size. If places are found where a moose has gone between trees, the spread of his antlers, if he has any, may often be closely estimated. On one occasion I followed the track of a moose which led up a hill, and between some small trees. The guide studied the evidences carefully. 
"No!" said he finally. "That moose can't have any horns. If he had, they'd have knocked the snow off that fir, or else he'd have scrope the other tree."

I was not sure that "scrope" was a correct past participle of the verb "to scrape," but I was quite sure that the pair of antlers I was looking for had not been carried between those trees.

Little assistance in judging the age or size of a moose is afforded by the teeth-marks on trees, where the bark has been peeled. After the moose has lost his milk teeth, and has come into possession of those of maturity, there is no increase in their size. An old moose is likely to have defective incisors, but often the front teeth of a three-yearold will show similar defects. The middle front teeth of mature moose are about half an inch in width. They are like gouge chisels, but are often scalloped into a sort of double gouge, which would give the hunter, intent on studying the "peelings" on trees, the impression that the teeth were much smaller than they really are. Furthermore, a large moose often leaves on the tree-trunk the marks of the narrower incisors at the end of the little row of chisels, causing the hunter to infer that the peeling was the work of a yearling. ${ }^{r}$

$\therefore$ See pp. 87-89. 
Many a clever stalk, which has led to a moose within easy gunshot, has ended in the disappointing discovery that it was only a cow moose, after all. The first question then, when a track is found is, is it a bull or a cow? The visible differences are not certain and precise.

The hoofprint of the cow is generally more pointed than that of the bull. The cow rarely peels bark; the bull of ten does, especially in the fall. The cow rarely browses fir; the bull rarely browses birch. The balls of excrement of the cow are oval and long; those of the bull are more nearly spherical, and flattened by being pressed together. If two or three moose are traveling in company, as frequently happens, certain tracks are likely to lead between trees which are close together, while the track of one animal may turn out -indicating the possession of a pair of antlers that could not be easily maneuvered in narrow quarters.

If a moose track leads to windward, and is three or four hours old, it is safe to follow it rapidly, for the animal's scent will not tell him that he is pursued. If the track is much fresher, but the moose is not stopping to feed, it may be followed somewhat rapidly. When, however, the track is 


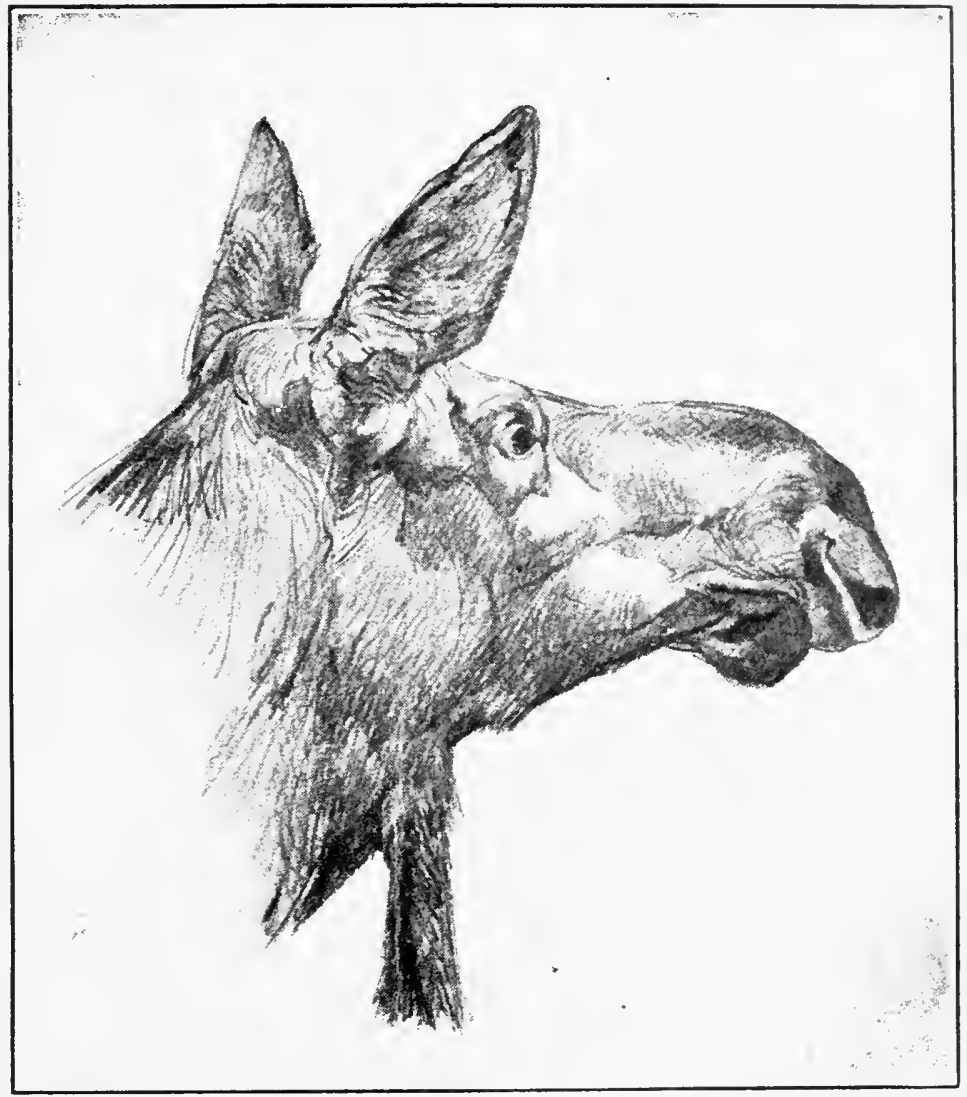

(C) by Carl Rungius

Head of a Yukon Cow

From a Drawing by Carl Rungius 

fresh, and it is evident that the animal is not far away, and has been feeding, the hunter should leave the track, making a series of zigzags across it, and keeping a close watch to windward. The purpose of this maneuver is to avoid getting on the weather side of the moose if he has made one

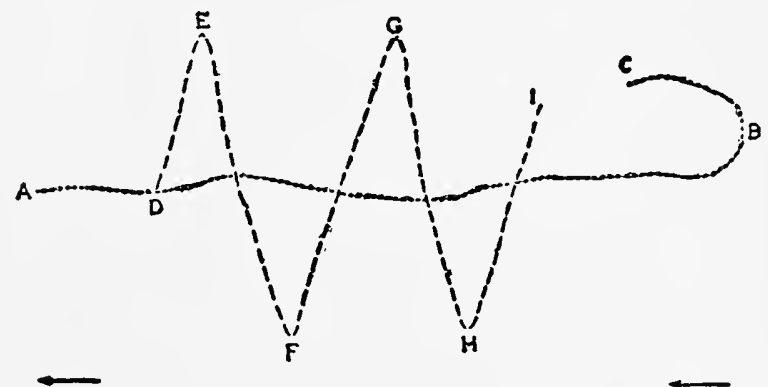

Hunting against the Wind

of his customary loops "down the wind" as a preliminary to lying down.

In the diagram the arrows indicate the direction of the wind. The dotted line represents the t "ack of the moose from $A$ to windward as far $\therefore$ ?. where he loops down the wind to $\mathrm{C}$ for a rest. The hunter, seeing that the track is fresh, zigzags DEFGH, and at I, if he has conducted the stalk skillfully, he may get a shot. On the other hand, if the hunter followed the moose track without zigzagging, he would not go far beyond 
$\mathrm{B}$ before the animal would get his scent, and take flight.

If the track leads "down the wind" the hunter may as before follow rapidly so long as the track is some hours old. In general terms it may be assumed that the moose will lie down for an

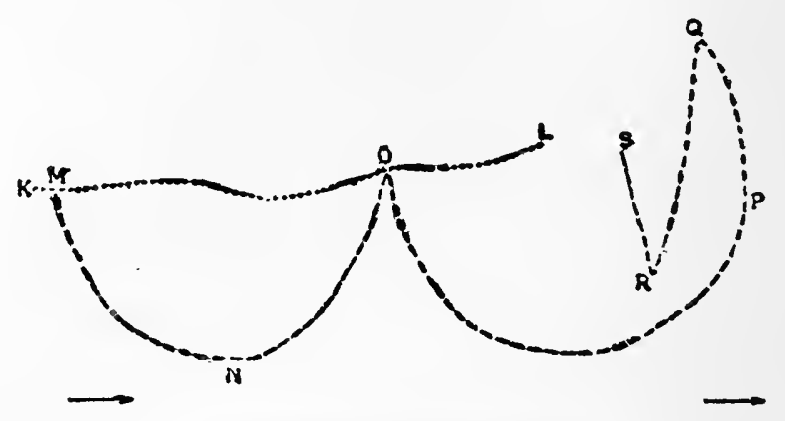

Hunting with the Wind

hour or two at a time, and he will lie down a number of times in a day. When a place is reached where the moose has lain, the "sign" will of course be fresher after he has left his bed, and caution must be exercised accordingly. When it is judged that the moose is not more than two or three hundred yards away, and is not traveling rapidly, as shown by his feeding, it is time to maneuver for the leeward position. This is done by making a series of loops, as in the diagram. The moose is going down the wind, from $\mathrm{K}$ to $\mathrm{L}$. The hunter, 
knowing that the wind favors the moose, makes a loop, $\mathrm{MNO}$, the loop having a radius of a quarter of a mile or more. He finds, however, that the moose is still ahead of him. He may make several such loops before heading the animal. When he makes the loop OPQ without coming upon the track, he assumes that he has the leeward position, and begins a series of zigzags, QRS, to hunt out the moose from the leeward side, as before. At $S$ he ought to get a shot.

Of course, at $\mathrm{O}$, or anywhere else, for that matter, the hunter may find that he has by chance come too close to the moose, where perhaps a thicket shielded him from view, and where the moose had the leeward position. In this case he may have to content himself with a running shot-or merely with an opportunity to measure on the ground the long strides which an unseen but frightened moose makes when a favoring breeze has brought to his nostrils the dreaded human scent. A breaking stick under the hunter's foot may similarly bring to naught a stalk which has been in other respects most skillfully managed. It is this uncertainty, this necessity for keeping every sense and every nerve keenly on the alert, that makes still-hunting in the moose country the finest sport that America affords. 
The tactics here described are much less resorted to where moose are plenty than in places where they are more rarely met. Indeed, it is always in the places where the difficulties of the hunt are greatest that the most skillful hunters are found.

When a yarding place of moose is found, indicated by browsing and peeling, the tracks crossing and recrossing, the hunter should at once seek the leeward side, and work his way into the yard by a system of zigzags, keeping a close watch to windward as he advances.

Much of the moose country of the remote Northwest is sparsely wooded, but in the portions of the moose's range which are most frequently visited by sportsmen the cover is comparatively thick. Under the latter conditions, if a moose is a hundred yards away he is usually concealed by trees and underbrush, and he is of ten invisible to the hunter at half this distance. In the summer and early autumn, to be sure, the moose is frequently seen in and about the water, at a distance of several hundred yards, but later, in the stillhunting season, the game is found among the thick growth of the ridges. The hunter, of course, prefers the more open woods, but he must take conditions as he finds them. For a fair marksman, armed with a good rifle, a shot at two hundred 
yards offers less difficulty than is usually met in still-hunting a moose which cannot be seen by the sportsman until he has come within fifty or seventyfive yards of his quarry.

If the moose is successfully stalked-that is, if the hunter comes within view and gunshot without frightening the quarry away-still the hunter should not fire without getting a good look at the head. It has happened many times that the animal which is seen is not the one whose tracks the hunter has been following. The moose which is seen may be a yearling or a cow casually met by the big bull which made the tracks-and the yearling and the cow are entitled to protection.

If the head is not in sight, and it is inexpedient for the hunter to change his position, he may make a low "wah!" sound, and thus cause the moose to turn his head. If it is not the head you want perhaps the call will bring the desired head, and its bearer, into view. In any event, if the head suits you you must shoot quickly, for once under way a fleeing moose is not likely to stop until he has measured off a long reach of timber land, and if again pursued he is sure to be on his guard.

A whitetail, when surprised, is quicker to start 
than a moose, but runs a much shorter distance. He may often be overtaken and shot after a run of two or three hundred yards. Occasionally a bull moose, if in the company of a cow, and with the duty of guarding the rear in a retreat, will stop after a few rods' run to find what the danger is that threatens. A bull alone will rarely do this.

When, at the end of a long and exciting stalk, a patch of black seen through the trees seems to tell the hunter that his moose is in sight, nerves should be kept in subjection and vigilance redoubled. One rarely sees the whole figure of the animal at such a time. The first question then is, is it a moose? There may be other black objects in the woods. Is it a bull? Don't shoot a cow, even if the law permits it. Are the antlers worth the shot? Remember there is a bag limit, and a mistake cannot be corrected after the bullet has left the muzzle of the rifle.

A hunter once followed a promising moose track in soft fresh snow, when conditions were favorable for a somewhat rapid advance. For nearly two miles the moose traveled at a steady walk, stopping rarely to nibble a few mouthfuls of browse. Then the track of another bull, accompanied by a cow, crossed at right angles. The hunter kept the 
straight course. Suddenly, less than a quarter of a mile beyond where the tracks crossed, off at one side, sixty yards away, could be seen the body of a moose, standing. A little inspection showed that it was a bull, and that the head would be a prize worth winning. A shot was fired, and the moose disappeared, while the hunter ran forward to be ready to fire again if he again came in sight of his victim. A few yards, and a second shot was fired; a few more, and a third.

The next run forward brought into view an unexpected spectacle. On the ground lay a bull dead; nineteen yards beyond stood another bull mortally wounded and unable to travel, while fifty yards farther off stood a cow, a puzzled spectator of the tragedy. The second bull dropped in his tracks without another shot. The cow stood for two or three minutes while a surprised and disgusted sportsman discussed the unusual event with an equally surprised guide. If there had been a single moose down, bearing on his head either pair of antlers, the sportsman would have been amply satisfied.

The lesson which this episode teaches is that the hunter should exercise all the care that is possible - it may still be insufficient. . . . The legal bag limit was one bull moose. . . . 
The moose, like Fuzzy-Wuzzy, requires a good deal of punishment to make a post-mortem possible. And it was said of Fuzzy-Wuzzy, it may be recalled, that

“. . . 'e's generally shammin' when 'e's dead."

Belmore Browne ${ }^{2}$ tells of an early autumn hunting trip in Alaska with A. J. Stone, in quest of specimens for the American Museum of Natural History. Two bulls were shot one morning, the pair falling about a mile apart. The party were engaged in dressing the smaller moose, intending afterward to take care of the larger one, when they were visited by a bull which appeared to be frightened. As they wished only two bulls they took little notice of the intruder.

"We had been skinning for only a few minutes when one of the Indians gave a grunt of surprise, and in an instant our noble red men were frantically shinning up the nearby spruces. Turning we saw the bull running toward us through a grassy glade, and we stood quietly watching him as he came on. He had seen the flurry on the knoll as the Indians scattered, but he seemed to be uncertain as to which course to follow, for he dropped into a walk and continued to approach un-Outing, October, rgr 5 . 
til he was only thirty feet away, where he stopped and looked over us. The Indians were jabbering excitedly on their perches, just in front of him the dead bull lay, Stone and I were standing in plain view, and yet many seconds passed before he turned and left us."

Later, on seeking the second moose, whose life was supposed to have ended several hours before, they found that he had disappeared. "There in the grass was the depression made by his great body, and numerous gashes in the earth showed where his antlers had torn up the sod. For a moment we stood dumfounded, then the realization came to us that our friendly visitor was our vanished prize!" The hunters hurriedly took their back track, and found and finished the wounded bull in a grove of alders. The moral of this tale is obvious: be sure your moose is dead. 


\section{CHAPTER V}

CALLING THE MOOSE

In some portions of the moose's range the close season is so adjusted as to include the period of the rut. This policy is encouraged by those who look with disfavor on calling as unsportsmanlike, and by those who advocate a considerable restriction of the kill of moose. The number of moose killed by aid of calling no doubt constitutes a small minority of all which are shot. Still, calling affords excitement, and it affords the enjoyment of the woods in twilight hours when Nature is in one of her most delightful moods.

The calling season extends, in general terms, from the middle of September to the middle of October. In northern latitudes, and at high elevations, it is a little later. The voice of neither bull nor cow is often heard at any other time. There are wellauthenticated instances, however, of bulls responding to the call long after the close of the rutting season-even as late as the end of November. 
The best bulls are likely to "come in" to the call in the first week or two of the season. After they have mated, the smaller specimens, and defeated suitors for female favors, will make bold to respond when they hear the cows' melodious confession of loneliness.

With regard to the conditions surrounding the practice of calling there has been some conflict of opinion. Stone, in The Deer Family, ridicules the claim that a bull moose will respond to a hunter's call in the belief that the sound is the call of a cow. But Mr. Stone's experience with the moose has been in the Northwest, where calling is almost unknown. Other writers describe the "loud bellow of the bull" as he rushes through the woods in the rutting season, seeking female companionship, assuming that it is the bull which calls. These writers either lack experience in the moose country, or have gained their experience on the Pacific side of the continent, where, as stated, calling is rarely practiced.

The statement that moose in Alaska and western Canada will not respond to a call is untrue. Wilfred H. Osgood of the United States Biological Survey relates how two bulls responded to a call sounded by Carl Rungius, the well-known sports-

* Page 3 ro. 
man and painter of big-game subjects, while the two gentlemen were engaged in a September hunting expedition in Alaska some years ago. ${ }^{2}$ And F. C. Selous tells of successful calling, of which he was an auditor and spectator, by Charles Sheldon and a half-breed guide in Yukon Territory of Canada September 25, 1904. The moose came within twenty-five yards, but was lost by the misfire of a cartridge. ${ }^{3}$

Sportsmen and guides who have been much in the moose ranges of Lower Canada and Maine agree that the bull is easily deceived in the rutting season by a skillful caller, and that it is the cow which calls, the bull's voice being rarely heard, except when, by a sort of grunt, he responds to a cow's call-or its imitation. ${ }^{4}$

The usual time for calling is the dusk of a still moonlit September or October evening or morning, and the preferred place is the edge of a broad barren. Can imagination picture a stage setting more beautiful in the eyes of one who loves the woods!

- National Geographic Magazine, July, 1909.

3 Recent Hunting Trips in British North America, pp. 227-232. Mr. Selous said the reply of the bull when responding to a call seemed to come from the throat, and reminded him "irresistibly of a human being in the throes of sea-sickness."

4 An old writer describes moose calling among the Micmac Indians of Acadia two hundred and fifty years ago, the voice of the female being imitated.-Denys, ubi supra, vol. ii., p. 423. 



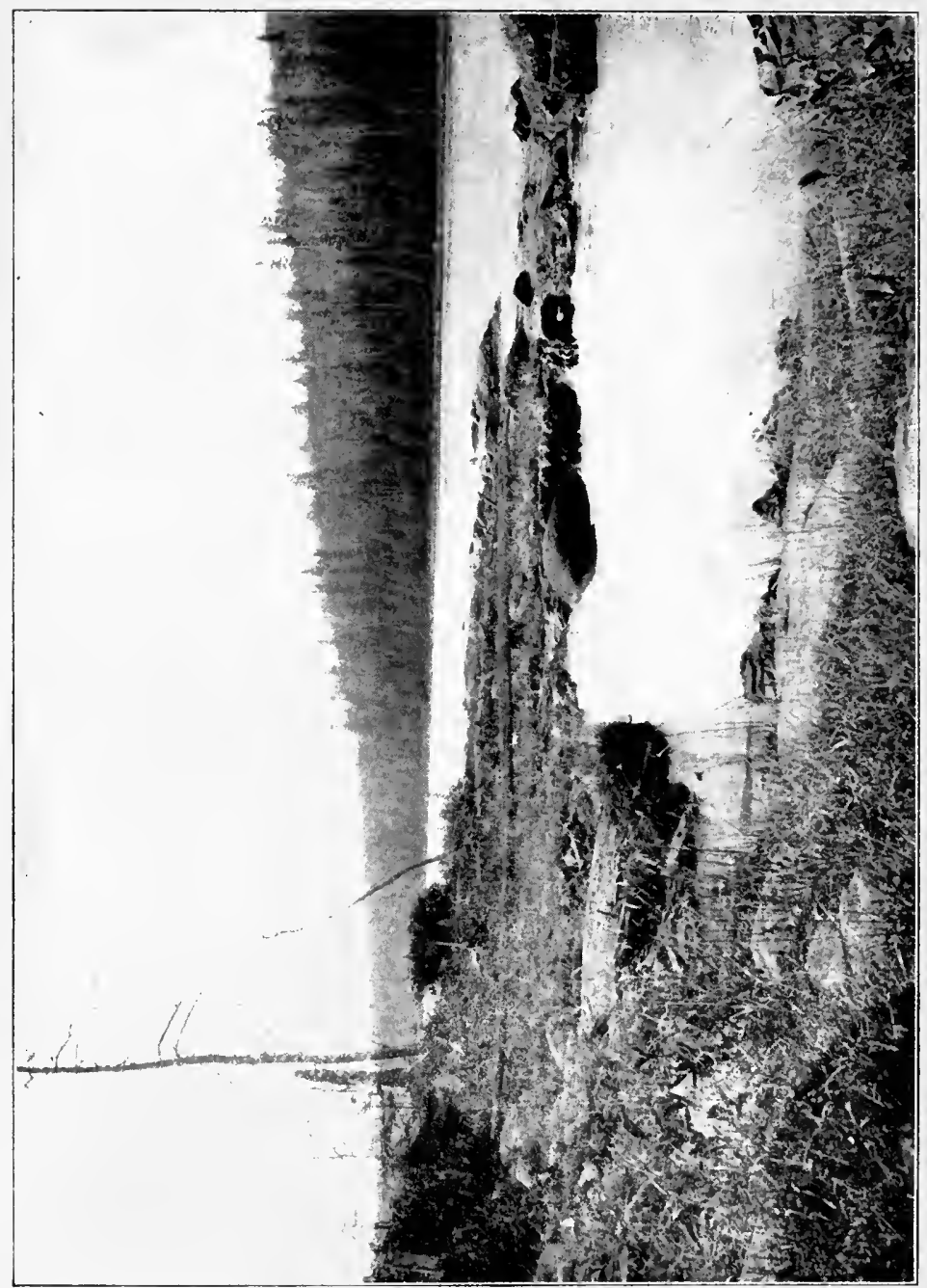

量 
If the vicinity of the stand is too open, the call may fail owing to the bull's disinclination to trust himself far from shelter; and there must be cover enough to conceal the hunter and the caller, of course. Furthermore, no intelligent moose would respond to a call from a place so open that a cow obviously could not remain concealed in it. On the other hand, too much shelter will give the bull a chance to view and scent the situation at close quarters without offering opportunity for a shot. The immediate vicinity of the stand, however, should be free from brush or other obstructions more than four feet high, for the sportsman must have an opportunity to inspect his quarry and judge whether the head meets his approval. Sometimes a bull, which has been coaxed forward for an hour or two by a skilled manipulator of the birchen horn, will stand for another hour partially in sight, but with his head concealed from view, while daylight, merging slowly into darkness, drops a curtain over the scene, and the hunt ends in disappointment.

An ideal calling stand is perhaps a high flat rock, with a fringe of brush affording concealment for the hunter. Height is desirable, so that the call shall carry its maximum distance. Height, too, decreases the chance that the moose will get the 
scent of the man. Sometimes, indeed, the caller sounds his first invitation from a tree-top, the hunter remaining on the ground.

The call is a low quavering tone, long drawn out _"Mwar!" or "Oo-oo-aw!" It is sometimes described as a whine. It begins in a high key and gradually descends an octave or two. The sound can be plainly heard two or three miles away, nature's wireless telegraph having a surprising radius when the air is not disturbed by wind. If it is necessary to repeat the call, the repetition is not given for ten or twenty minutes, ${ }^{5}$ and the second call is usually louder and more plaintive than the first.

If a bull hears the invitation, and is inclined to accept, his hoarse grunt, "O-oh-ah!" audible across a mile or more of barren or forest, tells the waiting caller that the imitation of the cow's voice was excellently managed.

After the bull's answer-and answers may come from two or more-breaking of dry branches

'A writer in Blackwood's Magazine for August, 1908, seriously asserts that the noise of a steam siren heard at a distance resembles the call of the cow moose, and that moose in Canada have often been shot after having been lured to the seashore by the steam sirens of ships passing in the fog. If a bull moose will respond to a fog signal sounded every minute or so, thinking it is the voice of a female of his own species, the long interval between calls in the practice of most moose callers would seemingly be unnecessary. 
as the animal charges through the woods may afford further encouragement to the waiting hunter. But there are likely to be long pauses in the approach of the moose. If two show a disposition to accept the invitation, the question of right of way may have to be decided. This is often done by the younger or weaker confessing his inferiority and leaving the field to the stronger. Occasionally the question of superiority is determined by wager of battle. If it is, and the two belligerents are in view of the hunter, he will have a spectacle which would be worth a small fortune if transferred to a moving-picture film.

If only one bull answers, or if one alone comes to the supposed trysting place, he is very likely to stop many minutes at a time to be sure a close approach is prudent. Often, if of an unusually suspicious turn of mind, he will completely circle the source of the sound, to make sure that no rivals are present, and that no danger is to be apprehended from any source. The freedom from wind is now the safeguard of the hunter, for if it were a windy night, the keen scent of the bull would detect the hunter, when the moose was in the lee of the hunter's position. To meet this maneuver of a crafty bull, when wind seems to 
favor the moose, the hunter will sometimes leave the caller, and going "down the wind" one hundred and fifty yards or so will stand ready to catch the bull off his guard while making his precautionary circle.

A bull's ability to follow a straight course through the woods to the supposed amorous mate is a source of wonder to sportsmen. His approach can often be noted by his responsive grunts, and by the sound of his antlers vigorously beating dead limbs of trees, making the greatest possible noise, as if to show the female what a fine fellow he is, and to intimidate all possible rivals. If he is seen at some distance coming slowly across a bog or other open space, the sportsman may perhaps advance cautiously toward him, while the caller remains behind to entice the bull along by occasional low notes on the bark trumpet.

The last twenty or thirty rods are likely to test the caller's skill severely. The responding bull is frequently suspicious or unduly deliberate, in which case he must be coaxed by various pleas and plaints, uttered in cooing tones, the caller at last muffling the sound by holding the mouth of the horn close to the ground. When other expedients fail, the caller will sometimes "speak bull," or imitate the bull's voice, to provoke the 
laggard to a fancied contest with another of his own sex.

In some places calling from a canoe on a pond or deadwater is a favorite practice. The first call would be given at a distance from shore, to give the sound the widest possible diffusion. When a bull answers, the canoe is noiselessly moved into a favorable position, preferably, of course, keeping in the lee of the intended victim. If vocal calls at such a time fail to bring the bull close enough for a shot, various other noises to denote the presence of a cow are made on the water-as by striking the water regularly with a paddle to imitate the sound made by a cow in walking.

Calling from a canoe may have unpleasant features. At best it is monotonous to sit in a canoe cramped and motionless for hours waiting for the answer which does not come. Such was the experience of a sportsman and a guide who returned to camp at two o'clock one morning after having spent the early evening hours in fruitless calling. After some questioning they admitted that they had both spent a large share of the night in the canoe in sound slumber.

There is considerable diversity in the calls made by cows, and still greater diversity in the imitations and tactics employed by successful callers. 
"One veteran backwoodsman is very successful with a couple of guttural coughs or sobs, followed by a scalp-lifting, blood-curdling wail, the 'spookiest' sound that any mortal could possibly utter."6 The results of calling, furthermore, even with an expert to manage the horn, are by no means so much of a foregone conclusion as some critics of calling are inclined to assert.

The value of the moon as an aid in hunting in the calling season cannot be overestimated. Without it the evening twilight will often prove too short, in view of the dilatory tactics of a suspicious bull, to bring the hunt to its logical conclusion. If the calling stand is approached by land, and not by water, it is well to spend the night there, under a light shelter tent, but without a fire, of course. A few calls may be given in the evening if conditions are favorable, but the morning calls are more likely to yield results. Calling should begin half an hour or more before sunrise. The hunter then has the advantage of increasing, rather than diminishing light, and he has the further advantage that there is no fresh human track to be scented by an approaching moose.

The horn, by means of which the call is sounded,

"Arthur P. Silver, "Moose Hunting in Nova Scotia," Empire Review, London, Nov., 1902. 
is a cone of birch-bark, usually about sixteen inches long. It is three-quarters of an inch in diameter at the smaller end, and three and one half or four inches at the other. ${ }^{7}$

The author of Habits, Haunts, and Anecdotes of the Moose (p. 99) tells of a hunter who with his guide pitched his tent "beside a giant boulder on one side of which a narrow open bog stretched away between wooded banks. ... As the sun was nearing the western horizon the guide climbed to the top of the boulder and sounded the call." Three bulls responded.

"The guide came down from his perch on the rock, and stationed his employer and himself behind a smaller boulder over which it was possible to look while lying on the ground. . . . The bull that responded last was, when the sun went down, already quite near, and coming steadily along. ... Another call and the bull's hoofs were heard beating the firm ground as he trotted up the slope toward the men. In full view of the hunters, and about ten yards from them, grew a bunch of sapling birches. There the moose paused and

7 Dr. Edward Breck in The Way of the Woods (N. Y., 1908), pp. 330337 , gives a good exposition of the art of calling, and a warm defense of calling as a sportsmanlike system of hunting moose. Suggestions for sportsmen who would learn to call their own moose are given by Douglas W. Clinch in Recreation for October, 1910. 
began a furious onslaught witn his antlers. Having tired of that he turned toward the hunters, and going down on his knees plowed his horns along the ground some distance, tossing them, well loaded with vines, moss, and earth. With a snort he shook these from his head, the dirt falling on and around the two men lying behind the rock."

But the distance was evidently still too great to risk a shot.

"Again the moose came on, and stood with his broadside toward them, not more than twelve feet from the muzzle of the rifle."

They managed to kill their game with three shots, though the moose twice regained his feet after falling.

When calling is resorted to by Russian hunters it is usual to "speak bull," the caller pretending to challenge his victim to combat with one of his own sex, instead of practicing the seductive wiles of the cow. ${ }^{8}$

Various devices are employed in America also to profit by the bull's combativeness in the season of the rut.

"The pounding on a tree with a club by the Tahltan or Kaska Indians in northwest British ${ }^{8}$ See pp. 327-329. 


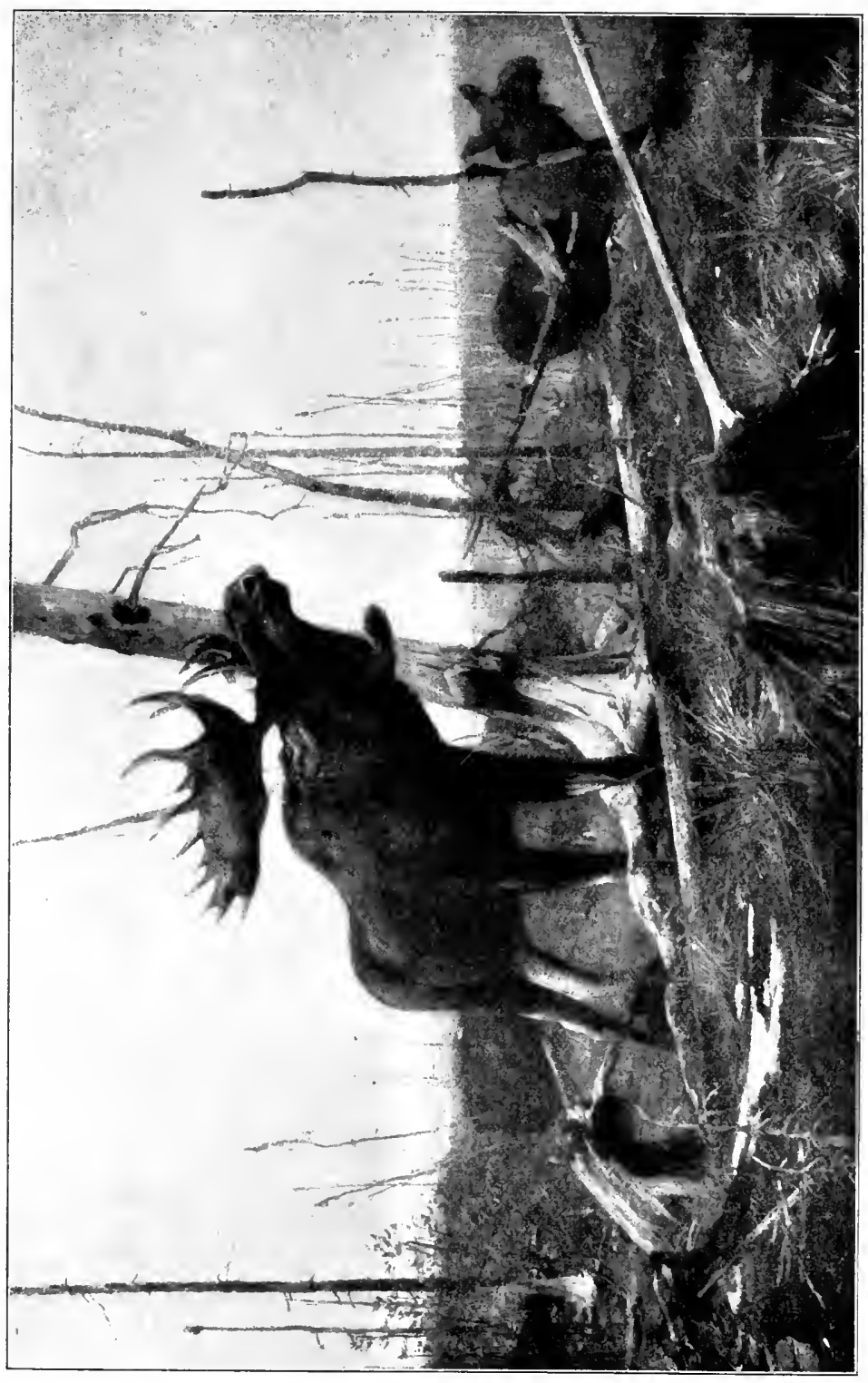

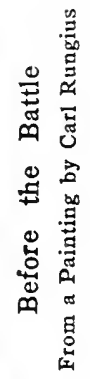

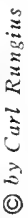



Columbia (among the best moose hunters in America), or pounding the willows with a dry shoulder-blade of the animal, by the Liard River Indians," according to Stone, will often serve to call a bull. 9 These sounds are intended to give a listening bull the impression that a fight is in progress, and he is eager to participate in the contest, in the hope of winning the prize for which the others are contending. But these seem to be chiefly the expedients of western Indians, and are rarely practiced by white hunters, or by the Indian hunters of the east.

- The Deer Family, p. 310. 


\section{CHAPTER VI}

\section{MISCELLANEOUS HUNTING METHODS}

IT would be interesting to study the means which have been employed in killing big game from prehistoric times down to the era of smokeless powder. Such a review of hunting methods would cast most interesting side lights on the whole subject of civilization and its development, and the development of inventive skill.

In the early prehistoric period man was nearly as wild as the wild animals which he sought for food. The great Irish elk, and his contemporaries of the animal kingdom, probably paid little attention to the hairy, skin-clad men, with stone axes and flint-tipped spears, whom they encountered. Men were few in number, and were doubtless disregarded by the larger animals, as deer disregard foxes in our woods today. If prehistoric men overcame the Irish elk, or other animals of such size and resourcefulness as the modern moose, it was accomplished by force of numbers, 
when the animal was overtaken in the water, or was helpless in the snow, or was otherwise at a disadvantage.

How early pitfalls, snares, and deadfalls were used we have no means of knowing. Primitive man needed such aids to supplement his primitive weapons, but whether he had sufficient ingenuity to construct them is another question. The evidences at hand do not show that he possessed genius of a very high order.

The chase has ever been the school of the soldier. The art of attack and defense, whether employed in hunting or in warfare, whether exercised against wild animals or against invading fellow savages, has been a matter of vital importance to all primitive peoples, and the nations which have survived in the periodical readjustment of the map of the world have been those which had advanced farthest in the development of this art.

In the Middle Ages kings and nobles knew no employment in times of war but the profession of arms, and little employment in time of peace but the sport of hunting. Among the American Indians, too, every able-bodied red man was a "brave" as soon as war was declared, and a hunter as soon as the last whiff of smoke from the pipe of peace drifted away among the tree-tops. 
The Indian system of warfare, a system in which stealth and the ambuscade were the chief characteristics, was cultivated in his pursuit of deer and moose. The most skillful hunter, furthermore, was usually the best warrior when the game trail was abandoned for the warpath.

Against the moose the Indian in the open woods found his bow and arrows comparatively ineffective. Often, however, the moose would be found in the water, or would be driven into the water, and then from canoes the Indians could attack him in force at close quarters. It would have been a battle worth watching. There was usually a dead moose at the end of the contest. These encounters often resulted in a few wrecked canoes and broken Indian bones, no doubt, but these incidents would be forgotten at the festive "tabagie" which would be held next day.

Whole villages joined in these drives. The best canoemen among the savages would form a crescent by their canoes on some lake, each end of the line touching the shore. Others, with dogs, would circle a wide stretch of territory, and drive the game into the lake. The men in the canoes would be armed with various weapons, prepared to dispatch the animals as they sought 
to escape by the water from the noisy line of

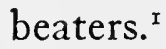

Nicolas Perrot, writing more than two hundred years ago, tells of moose drives among the Crees of the Lake Superior region, in which dogs trained for the purpose would unassisted drive moose into the water while the Indians lay in wait in canoes to slaughter the game. ${ }^{2}$

In many cases the game would be driven into a permanent enclosure which the Indians would construct on land. An interesting collection of animals would no doubt be gathered in as a result of a successful drive-moose, deer, and caribou often finding themselves companions in a common fate. ${ }^{3}$

Champlain describes one of these drives undertaken by the Huron Indians while on a foray into the Iroquois country in $16 \mathbf{I}_{5}$. The barriers leading to the small enclosure where the game was to be killed were eight or nine feet high and about fifteen hundred paces long on each side. The opening leading to the smaller enclosure, which may have been called the slaughter pen, was five feet wide.

'Charlevoix, Journal d'un Voyage dans l'Amérique Septentrionale, in letter dated March II, I72 I.

'Memoir of the Manners, Customs, and Religion of the Savages of North America (Cleveland, I9I I), vol. i., p. Io8.

${ }^{3}$ Charlevoix, ubi supra. 
"When everything was ready, they started half an hour before daylight to go into the woods about half a league from their enclosure, separated from one another eighty paces, each having two sticks, which they beat together, marching slowly in this order until they came to their enclosure... When they reach the end of their triangle they begin to shout and to imitate wolves, which are plentiful, and which devour the deer." The drive was repeated every two days, and in thirty-eight days they captured one hundred and twenty deer. ${ }^{4}$ Snares were usually set at the narrowest part of the enclosure to guard against the possibility that the animals would break down the barrier and all escape.

The Indian frequently employed the snare in his moose hunting. For this purpose he used a strong strand of moose hide, twisted, stretched, and dried, and then worked until sufficiently pliable. A slip-noose of this material was suspended where moose would be likely to passover a runway or near a spring. The line was run over a strong upper limb of a tree, and a heavy clog was attached to the end farthest from the noose. The animal's head once in the noose,

4 Voyages and Explorations of Samuel de Champlain, translated by A. N. Bourne (N. Y., 1906), vol. ii., pp. 91-93. See also New Englands Prospect, by William Wood (London, 1634), part ii., chap. xv. 
the strain would release the clog, which would fall, and the noose would be drawn taut. The animal would struggle, of course, but the end was never greatly in doubt. The moose's indifferent vision made this method of hunting easy, and many moose have been taken by Indians in this way. ${ }^{5}$

In winter, with the snow deep and crusted, the Indian on his snowshoes found the moose an easy victim, without other appliances than his bow and stone ax. This system of hunting was much more frequently practiced than driving. A story of hunting on the crust is told by Baron de Lahontan, a young Frenchman who spent some time among the Indians of Canada. ${ }^{6}$ His hunting trip was made in the winter of $1685^{-86}$, "forty leagues north of the River St. Lawrence."

"I spent the entire time hunting moose (ori-

5 Campbell Hardy describes a somewhat different method of snaring practiced by the white settlers in Nova Scotia more than sixty years ago. Snaring was illegal at the time. See Sporting Adventures in the New World (London, 1855), vol. i., pp. 180, 189. Campbell Hardy represents the best type of British sportsman. His books, though long out of print, have given pleasure to two generations of readers. His readers of the present day will be glad to know that "Lieut." Hardy, in the person of Maj.-Gen. Campbell Hardy, was still living in 1914 at Dover, Eng. His interest in sports is unabated.

- Nouveaux Voyages dans l'Amérique Septentrionale (The Hague, 1703), vol. i., pp. 73-77. See also Jesuit Relations (1651-52), vol. xxxvii., pp. 195-197. 
gnaux) with the savages, whose language I am learning, as I have intimated to you several times. This hunting is performed on the snow, with snowshoes (raquettes), as you see drawn on this paper. These snowshoes are two feet and a half long and fourteen inches wide. . . .

"We found five, ten, fifteen, or twenty orignaux in a body, which together or separately took flight, and sank in the snow up to the breast. If the snow was hard and packed, or if there was a crust on the surface caused by a season of dampness followed by frost, we came up with them after pursuing them a quarter of a league, but if the snow was soft or freshly fallen we were obliged to pursue them three or four leagues before we could capture them, unless the dogs should bring them to bay in places where the snow was deepest. When we overtook them we shot them with guns. Sometimes they become furious, and make an attack on the savages, who take refuge behind trees to protect themselves from their hoofs, with which they would trample them to death. As soon as they have been killed, new huts are made on the spot, with large fires in the center, while the slaves skin the animals and stretch the skins to dry.

"One of the soldiers who accompanied me said that it was necessary to have blood consisting 


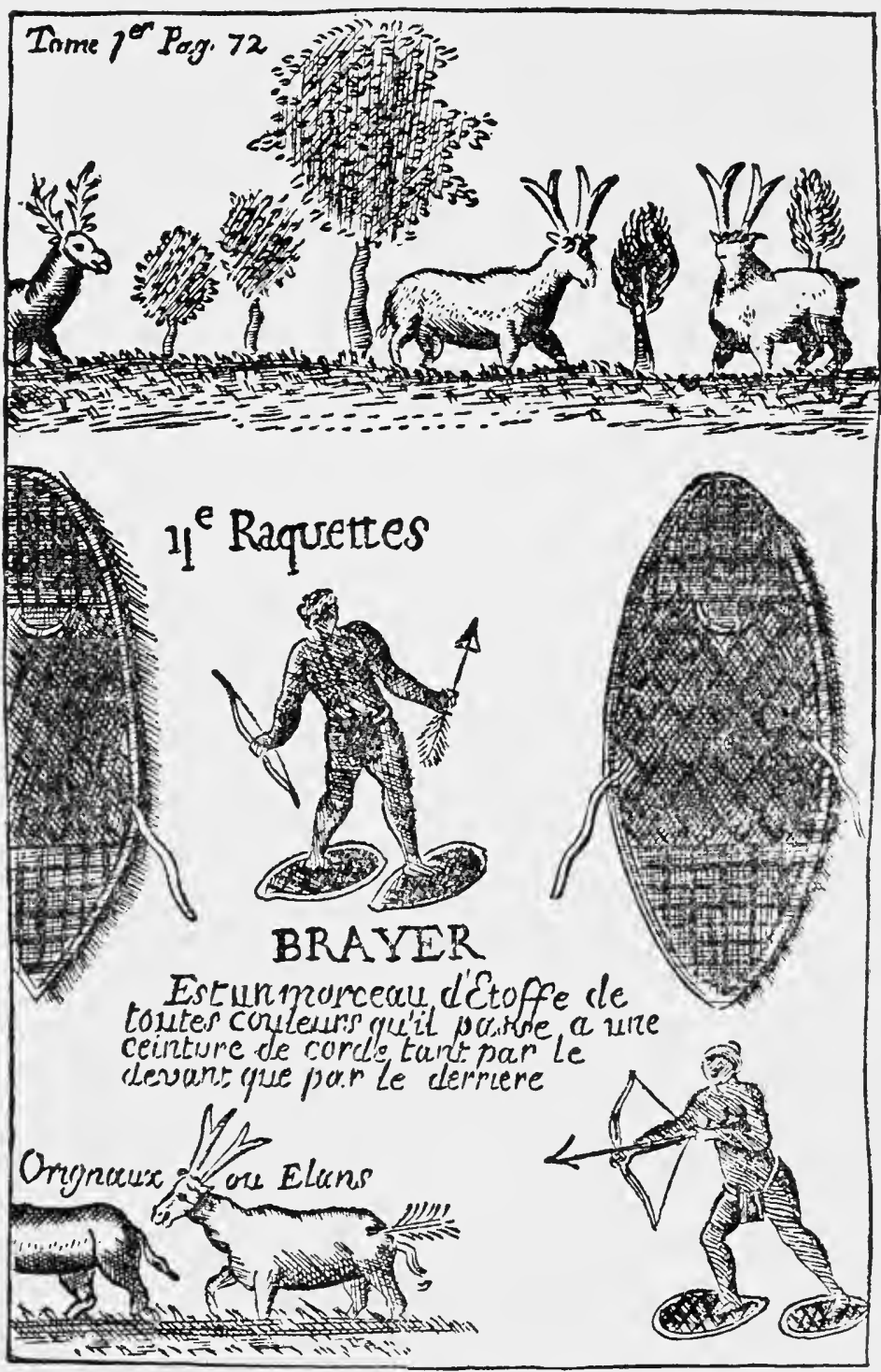

Crust Hunting in the 17 th Century 
of brandy, a body of brass, and eyes of glass to resist the great cold which we encountered. This was not without reason, for we were compelled to have fires all about us during the night.

"As long as the meat of these animals lasts, the savages scarcely think of moving, but when it is consumed they make a new discovery and a similar slaughter. This hunting is continued until the snow and ice melt. . . As soon as the rivers are open they make canoes with the skins of moose, which they easily sew together, after which they cover the seams with clay in place of tar. This work lasts only three or four days. These canoes are used for returning home, with all the baggage.

"This, monsieur, was my amusement for three months in the woods. We took sixty-six orignaux, and we could have slaughtered twice as many if we had been hunting for profit, that is to say, expressly for the skins. ... I have enjoyed hunting so much that I have resolved to do nothing else when I have leisure."7

7 The accompanying plate, from Lahontan's book, illustrates the "bear's paw" snowshoes in use in his time. The upper picture seems to represent a forest, with a wapiti and two moose hock-deep in the snow. In the lower picture crust hunting is shown. The Indian, like the trees seems to be in summer garb, except for his snowshoes.

A good narrative of a snowshoe hunt with Indians on the upper Ottawa-the snow five feet deep-is given by "a military chaplain" in Three Months among the Moose (Montreal, 1881), pp. 29-53. 
Among the older woodsmen of today are many who remember when such midwinter moose killing by white men, for the logging camps and frontier settlements, was very common. Nathan Moore, a famous character of the Maine woods a generation ago, and a generation earlier still, for that matter, kept a record of the moose he had killed in seventy years of active woods life. At his death in 1906, at the age of eighty-eight years, his score stood at 276 moose. Fifty years ago the number of moose which one was permitted to kill in Maine was no more limited than the number of quarts. of raspberries he might gather.

Nathan Moore's practice, as related to me years ago by his son Chandler, was to set out from home with snowshoes, muzzle-loader, and pack, and look for game for the backwoods market. As soon as moose "sign" suggested caution, Nathan would take from his pack a suit of sheeting, which he would pull on over his ordinary clothing, and thus clad would advance carefully, the white clothing making him inconspicuous against the background of snow. A moose yard once found, a general cleanup of all the animals in it was an easy matter, for in the deep snows the larger hoofed animals are helpless. The game would be dressed and hung up, and nature would provide cold- 
storage facilities until the hunter should return and sled the meat and hides to market.

"Walking down" a moose as a method of hunting is on the border line of good sportsmanship. It is on the wrong side of the border, however, if the snow is deep or crusted, and the hunter is on snowshoes. A good tracking snow is needed, and more endurance on the part of the hunter than most men possess, for the victim must be given little time for rest or feeding. The moose will often turn back toward the point from which he started, and the hunt frequently ends near the place where the walking match began.

A writer in Field and Stream for January, I907, tells of walking down a large bull, in the Dead River country of Maine, following him from ro o'clock Sunday morning until 3 Friday afternoon. The two men carried blankets and food, and killed small game from time to time. They camped on the trail without shelter, covering every day, as they thought, about four miles an hour through most of the hours of daylight. The snow was four inches deep when the start was made, but mild weather reduced it materially. The last day of the chase the track showed signs of a bleeding foot. The moose was evidently in 
distress, and when finally the hunters came in sight of him he stood his ground while the two men circled about him less than fifty yards away. "A venturesome man could have killed him with a knife," says the narrator of the story, but in this he was probably mistaken. Not being venturesome he killed him with a .405 caliber bullet, at close range. One cannot but suspect that this moose had been suffering from a wound or other partial disability. With deeper snow the enterprise would be relatively easier, but it could not be considered legitimate sport.

"Walking down" is sometimes the final incident of a hunt in which, for a consideration, a crafty guide guarantees a moose to an inexperienced sportsman. On one occasion, years ago, I was returning from the woods, and found myself in the general lounging room of the sole hotel in a frontier settlement awaiting the supper call. Some one announced the arrival of a tote team with a moose, and sportsmen and guides, with one accord, went out to inspect the prize. The head was nothing remarkable, and I was turning away when a guide nudged me, and said in an undertone, "Looks like the Dawkins trick!"

The name was not Dawkins, but for our present purpose this will serve as well as any. 
The expression was new to me then, so I asked for an explanation.

"You see that wounded leg with a bad swelling?" said the woodsman. "And you see there's no swelling where the other bullets hit? It takes hours for a wound to swell like that, and it won't swell after he's dead, that's sure. But the sport says they suddenly came on the moose and finished him in short order. If that's so, somebody else had given him that bullet in the leg the day before."

"But what is the Dawkins trick?" I asked.

"Oh, that's what they call it around here when a man cripples a moose so he can't travel, and then for a good price guarantees that a sportsman will get a moose or no pay. Of course you can't fool an experienced man in that way, but one who's never killed a moose may fall for it. When the bargain's made it's easy to take the sport back to where the cripple is waiting to be finished. And nine times out of ten the sport is kidded into thinking that he fired every shot which ever touched the moose. The Dawkins boys were great at that game."

The writer in Field and Stream tells of his guide "guaranteeing to bring me within easy shooting distance within eight days, or no pay." Perhaps he was a victim of the Dawkins trick, after all. 


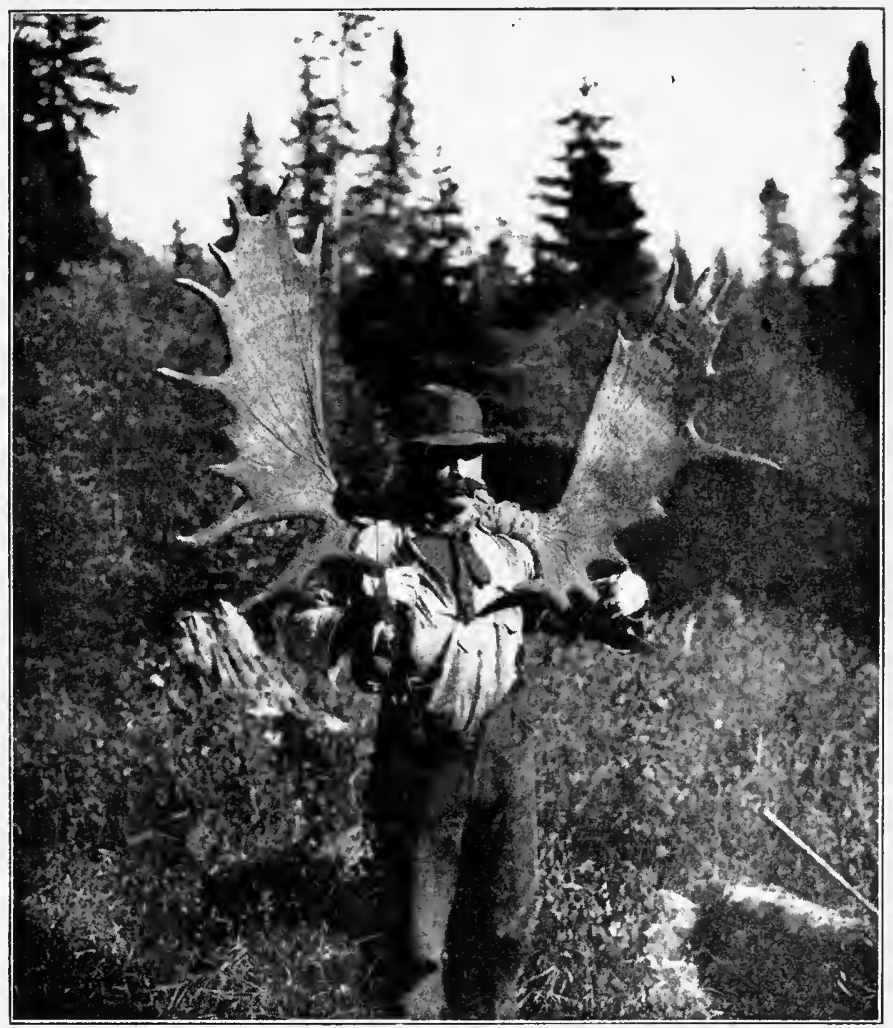

Bringing in a Good Specimen

Moose Shot by Carl Rungius on the Little Southwest Miramichi River, N. B. 

Of other hunting systems, obsolete or obsolescent, little need be said. Dogging is generally looked upon with legal and popular disfavor, though it is still the usual method of hunting the Scandinavian elk. The practical extinction of moose in Cape Breton is due to persistent use of dogs in hunting. A moose will run from a pack of dogs, even when at close quarters, but he will turn and face a single one, as soon as the dog bites him on the gambrel muscles. ${ }^{8}$ Thus held at bay the moose would fall an easy victim if the hunter quickly and cautiously followed up his advantage, but at sight of a man the moose is likely to take flight again

Jacking, like dogging, crust hunting, and snaring, is generally forbidden by law, along with other systems of hunting which take advantage of the moose's weaknesses or physical limitations. Those who are interested in flash-light photography may find the jack a useful aid, but as an aid in killing game jacking is not considered "fair chase."

In jacking the fact should be borne in mind that the light itself has no terrors for a moose or other animal. It is associated with none of the sources of danger which wild animals have learned to fear. A moose will look toward the jack, or

${ }^{8}$ Pattillo, Moose Hunting, Salmon Fishing, and Other Sketches of Sport (London, 1902), p. 250. 
toward the lighted objects on shore, with equal indifference, except that his curiosity is aroused by the mystery of an unfamiliar condition. If he is facing the jack, and a shot is fired, he will run from the noise, which he associates with the light, and the man with the jack need not fear an encounter at close quarters. But if the moose is facing away from the jack, gazing at the trees on shore bathed in supernatural light, as he often does, and someone behind the jack fires a shot, the animal will strike for deep water, associating the gunshot with the weird illumination of the forest at an hour when usually all is dark.

To the moose the strangely lighted woods are the source of danger, and impelled by fear he gets the reputation of having the temper of a wildcat, combined with the courage of a grizzly bear. Moose have frightened sportsmen many times, and wrecked canoes in some cases, when blindly fleeing from an imaginary enemy on shore. They have seemed to be assuming the offensive, when in reality they were in the panic of precipitate flight. In these cases a cow moose is as dangerous as a bull. ${ }^{9}$

-See "One Season's Game-Bag with the Camera," by George Shiras, 3d, in National Geographic Magazine, June, 1908, p. 415. See also "Hunting Big Game with Flashlight and Camera," by William L. Underwood, in Country Life in America for June, 1910. Dr. Charles 
A different view is entertained by $\mathrm{H}$. HeskethPrichard, an English sportsman, who describes moose jacking in the Canadian wilderness. ${ }^{\text {Io }}$ But the Englishman's experience in the moose country is somewhat limited. When the jack is turned on the moose, according to Mr. Prichard, the creature "almost invariably charges, and, be it big bull, cow, or yearling, it has in four cases out of five to be shot in self-defense, as the animal, maddened by the glare, will rush right aboard the canoe." The present writer, however, is unaware that a single instance is recorded where a hunter has lost his life in such an encounter.

Driving is still occasionally resorted to where the country is more or less open. Several hunters conceal themselves at positions two or three hundred yards apart in the more open land, while one or two beaters circle the thickets and, entering from the farther side, seek to drive the game toward the line of rifles. A drive may also be useful as a last resort when the snow is crusted, but not deep, and "still" hunting is out of the question. Driving game of various sorts is common in Europe, but in this country it seems to be looked upon as a

M. Whitney, in Country Life in America for June I, I9I2 ("Two Months with the Moose and Deer of New Brunswick"), gives valuable suggestions on the subject of game photography by daylight.

xo Blackwood's Magazine, Aug., 1908. 
lazy man's expedient. Most sportsmen prefer a more active participation in the hunt.

A passive form of still-hunting, when dry leaves and the usual tangle of dead brush underfoot make it impossible to walk in quiet through the woods, is to sit on an open hardwood ridge and wait for the chance approach of a moose. The charms of an afternoon in Indian summer will afford ample reward, even if no animal larger than a squirrel is seen. A few hours of a sunny day in early winter may be similarly passed in keen enjoyment -if the first snow of the season has softened under the midday sun, and crusted in the chill air of a frosty night, leaving the snow as noisy as the dry leaves of October.

To ears assailed daily and nightly through most of the year by the sounds of the cities, the solitude of the woods when the air is still is sure to be restful. Such dreams as pass through the mind as one sits - eyes wide open-waiting for the moose or deer, which perhaps never comes! The mossy stump of the old-growth pine yonder brings to mind the picture of a former generation toiling laboriously with their oxen to get the great sticks of pine to the river and to the market, leaving behind the spruce for the children and the grandchildren to cut when 
the supply of pine should be exhausted. The stump stands high above the ground, showing the depth of snow when the ancient wood-chopper on his snowshoes invaded the virgin forest.

What scenes had that stump, and the tree of which it had been a part, witnessed! It had stood there since long before the Genoese navigator unrolled for mankind the map of a larger world. Still sound at the core, it will stand there long after the present generation has made way for the great-grandchildren of those who stripped the forests of the pine.

As one idly dreams of the ebb and flow of the snow fields in the many years which have passed since the old pine was felled, of the moose which browsed there before the white men came, of the Indians who hunted them, of the hungry wolfpack which had attacked them when helpless in winter drifts, he may perhaps hear, far down the slope of the ridge, the breaking of a stick, followed by silence. What could have caused the stick to break? There it is again, and nearer! How the blood tingles at the thought that it may be the long-awaited moose!

It could not have been a squirrel or a rabbit, and a man would not spend so many minutes in moving so short a distance. And that dark 
object-it was not there before! All the senses, especially sight and hearing, are now centered in that shadow beyond the thicket. A few steps to one side would solve the question. But in the silence of the woods the rustling of a few leaves disturbed by the feet, or the crunching of frozen snow, would convey a message down the hill, just as the breaking sticks and rustling leaves have brought up the hill a message that some animal is abroad. The nervous tension is great, but impatience is repressed by the recollection of hours vainly spent in quest of game.

The distance is hardly a hundred yards.

Again the shadow moves. Will it perhaps move away, to be seen no more? If one stood up he could possibly see the outline of the dark object. Nerves have their limitations, and patience too, so the hunter carefully pulls back the hammer of his rifle, at the same time pressing the trigger so that the mysterious dark object shall not hear the click of the sear. The hammer at full-cock, and the trigger released to hold it ready for a shot, the hunter rises. Above the dark shadow in the thicket the broad antler of a moose is plainly visible! It moves up and down as its owner nibbles browse from the striped maple. . . .

At the end of a sudden outburst of noise and 
confusion there is a change of scene: the closing picture shows a moose lying prone, and a hunter standing close at hand looking down on the accomplishment of his task, and the realization of his hopes. Patience, steadiness of eye and hand, and alertness of mind have many times turned failure into success, in hunting as in the other enterprises of a lifetime. 


\section{CHAPTER VII}

\section{ARMS AND EQUIPMENT}

The choice of a weapon for moose huntingcaliber, powder charge, and weight of bullet-has long been a subject of controversy, and the possibility of ending the controversy becomes more remote with every improvement in firearms and ammunition which is placed on the market.

The $.30-30$ was the first widely-used hunting rifle loaded with smokeless powder and giving higher velocity than the black-powder guns. It is powerful enough for deer, but inadequate in moose hunting, as the many wounded moose which have escaped testify. Now in their turn the automatics are enjoying a season of popularity, but they too lack the power of the magazine rifles using the .405 , or even the $.45-70 \mathrm{~h}$. v. cartridge. This criticism is not directed against the automatics as such, but only against the inadequate ammunition with which they are loaded, and then only when it is proposed to use them in hunting 
moose. Some of the automatics, like the $.30-30$ 's, are good deer guns, but at present they have their limitations.

Another class of rifles now warmly recommended by zealous partisans have a caliber of .25 or less, their advocates claiming that their high velocity makes up for deficiency in other respects. High velocity, of course, gives flat trajectory, which is important in long-range shots where it is difficult to judge the distance accurately. But there are few long-range shots in moose hunting. It is safe to say that a considerable majority of the moose killed in the still-hunting season are shot at less than one hundred yards' distance. The moose is a creature of the woods, and few objects can be seen in the woods at a greater distance than one hundred yards, whereas the caribou on the barrens is often shot at several times this distance.

The small-bore advocates claim that a I20grain bullet, of .25 -inch caliber or so, driven with a muzzle velocity of 3000 feet a second, will do the work of a 300-grain bullet of .40-caliber which leaves the muzzle at 2 roo feet a second. But men who have tested the theory on big game have come home disappointed. A certain high-power rifle of .22-caliber, with a 70-grain bullet and velocity of 2900 feet, has also been recommended for moose 
hunting-by men who never used it for that purpose. Much depends on the "mushroom" formed when the bullet strikes, and it is expecting too much of a bullet of 70 grains, or 120 grains, no matter at what velocity it is driven, to expect it to form as effective a mushroom as a bullet of three times the weight. Increased weight and breadth of front of a bullet, even if there is some sacrifice of velocity, will increase the "shoch" incident to the hit, and it is the shock that stops the animal.

It is a common error to claim that because a certain cartridge has killed a moose the cartridge is of course adequate for this class of hunting. The .30-30 and many other rifles have been recommended for moose hunting, following this reasoning, ignoring the many wounded animals which have been lost. And it is idle to add the common argument, "If you hit 'em right it'll stop 'em"- - as much as to say that the gun will do its work; the only trouble is with the man behind it. You would of course prefer to strike in the fore quarter, but you will have to be content with a different hit if the fore quarter is behind a heavy tree, or if the animal is running away and offers only his hind quarters as a mark. "Don't send a boy to do a man's work," to quote a proverb common on the New England farms. 
In Newfoundland a number of years ago, while looking for ptarmigan with a .22-caliber rifle I came across two caribou. They were on the opposite side of a deep ravine, and about seventy yards distant. Our supply of fresh meat was low, and ptarmigan were scarce, so I pointed the slender gun barrel in the direction of the smaller caribou's vital organs and pressed the trigger. Both animals pricked up their ears and looked about as if uncertain from what direction the feeble report had come. I slipped in a fresh cartridge and fired again. They appeared to be nervous, and nothing more. I was repenting that I had fired at all, and was in doubt what course to pursue, when my caribou turned around. As he did so his legs gave way, and he slid down the side of the ravine in a lifeless heap. Two hollowpoint bullets, each weighing 35 grains and propelled by $4^{T} / 2$ grains of black powder, had killed a yearling caribou-but I am not prepared to defend the .22-caliber rifle as a fit weapon for caribou hunting.

A leading firearm manufacturing company recommends a cartridge the bullet of which stops inside the skin of the animal, because it "delivers its whole energy," calling attention to the fact that if the bullet passes through and beyond the 
animal a portion of the energy is wasted. But such waste of energy, or excess of power, will do no harm.

The wound at the point of emergence of a softnosed bullet is much greater than that at the point of entrance. If the bullet stops inside the skin, however, and the ground is bare and tracking difficult, the external flow of blood from a mortally wounded moose may be insufficient to enable the hunter to follow him effectively. The bullet should have a soft point, to insure mushrooming, but it should have ample power of penetration as well. At best many soft-nosed bullets, fired from even the most powerful rifles, will stop inside the skin of the moose.

Some experienced moose hunters who have used the present United States Government cartridge carrying the "spitzer" full-jacketed bullet weighing 172 (or 180) grains, recommend it highly. The bullet does not mushroom, but in nearly every case it turns over when it strikes, making a very effective wound. Its muzzle velocity is about 2600 feet. In some sections, however, the use of fulljacketed bullets in hunting is forbidden by law.

A rifle of less power than the so-called $.30-40$, in respect either to velocity or weight of lead, should be rejected as a weapon for moose hunting. 
A still more powerful load, if the hunter does not mind the recoil, would be better.

Rifles constructed on the bolt principle have their advocates. On two occasions, however, the author has taken bolt rifles, of different types, on November hunting trips, and in both cases found his rifle temporarily disabled when melted snow had had an opportunity to freeze under the bolt, thus crippling the firing mechanism. Hammer guns have never played him such a trick, and most of his moose-hunting trips have been made in the season of November snows. On one occasion the spring of the tubular magazine of a hammer rifle was for a few minutes obstructed by ice, but the firing mechanism was not affected, and the weapon was still in condition for use as a single-loader.

Most firearm salesmen in the cities are unsafe advisers in the selection of rifles for this class of sport. Their knowledge of ballistics is indifferent, and their experience in moose hunting is usually zero. A novice should seek advice from an experienced moose hunter, who does not look to the advertisements of the manufacturers for his facts.

Practice at the target, especially in sharr,y contested competitive matches, serves in a measure 
as a sort of inoculation against "buck fever." If a sportsman cannot find time and opportunity for target practice before going into the game country he must expect either to lose game which he would gladly kill, or else to accept the aid of his guide's rifle. Many guides expect to give this assistance; some even persist in shooting when they know that their aid in making a kill is not desired or needed. To guard against this latter fault the author for many years past has required his guide to carry a .22-caliber rifie or .2S-gauge shotgun-it keeps the guide out of mischief. If a grouse or rabbit should show himself, and there would seem to be no danger of scaring bigger game, it is easy to exchange weapons for a moment.

Assuming that the sportsman has a rifle, wisely selected and carefully tested at the targets, and a moose which measures up to requirements offers himself as a sacrifice-what then? Whether the moose is standing or running, the hunter will do well to aim each shot as carefully as if there was not another cartridge within twenty miles. This does not mean to let the moose get away; it means to seek to make the first shot effective, and not to rely on the second, and third, and fourth, that may be pumped out of the magazine. One, or two, or three shots carefully but quickly aimed- 
the series continuing as long as the moose remains in sight and on his feet-will usually be more effective than double the number fired hastily with the idea that out of a larger number more bullets will be likely to take effect.

Magazine rifles have led to carelessness in aiming, and automatic rifles have a tendency to increase this carelessness still further. Van Dyke, the author of The Still Hunter, writes: "From the day I got a repeater and learned how to keep a string of empty shells whizzing over my head, my shooting has become steadily worse." This is not an argument against improved firearms, but against carelessness. The magazine is a convenient means of carrying ammunition, and incidentally it has become a convenient means of wasting it.

Even if a skilled marksman, the moose hunter should not leave camp looking for game with less than ten or a dozen cartridges. Moose are sometimes finished with a single shot, but not often. After the first cartridge has been fired it may be a stern chase, with a quick succession of running shots. In such a running battle many of the bullets are pretty sure to find their billets in the trees, for as the moose runs the hunter's glimpses of him are usually few and brief until he dis- 
appears. In many cases a moose will take a lot of punishment and still travel. Judge Caton said that moose have been known to run half a mile with a bullet through the heart, but he wrote in the days of black-powder rifles. A hunter, after such a stern chase, his ten or a dozen cartridges gone, will probably resolve that next time on leaving camp he will drop a packet of half a dozen extra cartridges into the dinner pack, as an anchor to windward. They may not be needed, but they will be highly prized if they are.

Opinions differ regarding the point at which to aim, as well as regarding calibers and loads. Sir Henry Pottinger, an experienced English sportsman, whose specialty in hunting was the Scandinavian elk, said: "There is no better weapon for elk than a .450 or .500 express, and no deadlier shot than through the base of the broad neck." Others advise aiming for the brain. But unless one is pretty sure of his marksmanship, he would do better to aim for the shoulder. The shoulder offers a much larger mark. A soft-nosed bullet intended for the brain may easily damage the scalp of a fine head; and a bullet which should enter behind the ear, or shatter a cervical vertebra, may easily miss the animal altogether.

I Encyclopedia of Sport and Games (London, I9I I), vol. ii., p. I79. 
Clothing and Footwear.-Clothing in the stillhunting season should be warm, noiseless, and adapted to resist moisture. Corduroy, canvas, and leather should be avoided. Many a moose has been lost because of the slight scratching sound, which the wearer scarcely hears, caused by corduroy or canvas brushing against the dry underbrush in the thickets into which the hunter is led by the fresh tracks of a much-coveted moose. Moleskin, if all-wool, is excellent for knee-breeches, and all-wool Mackinaw is the most popular material for coats.

Many hunters favor gray as a color, because the backgrounds are grayer in the season of stalking than in that of calling. Brighter colors than gray, however, as a safeguard against the carelessness of excitable sportsmen, are not seriously objectionable. $^{2}$ Some sportsmen object to black clothing, asserting that moose associate black with the color of the bear, an animal dreaded on account of his inclination to prey upon the calves of the moose species.

"The chief end of man," according to the catechism of the woods, is the end where his feet are. With a pair of helpless feet the clearest

2.See p. 90. In Saskatchewan and Manitoba big-game hunters are required by law to wear white clothing. See p. 50 . 
head and steadiest hand are usually about as helpless. But footwear is a subject of more disagreement among woodsmen than clothing. The lumberman's "shoepacks" are favored by many for still-hunting, and are excellent when the ground is bare. But the inexperienced wearer will find the bottoms altogether too slippery for comfortable use on up-grades when the ground is covered with two or three inches of snow.

For the season of snow a good outfit for the feet consists of heavy woven leggings, such as woodchoppers wear, worn outside the ordinary stockings, and boots of rubber and leather. The rubber of the boots comes nearly up to the ankle, and the leather six or eight inches higher. But the rubber soles should be deeply checked and ribbed. When worn smooth on the bottoms these boots in wet snow are as slippery as shoepacks. Similar boots, but of smaller size and without the leggings, are good for the season of bare ground.

In the calling season the winter outfit of thick woven leggings and heavy waterproof boots will be appreciated. As one stands, almost motionless, hour after hour in the morning or evening twilight of late September, eating occasionally a handful of frozen blueberries, he will need his warmest clothing and footgear. The calling stand 


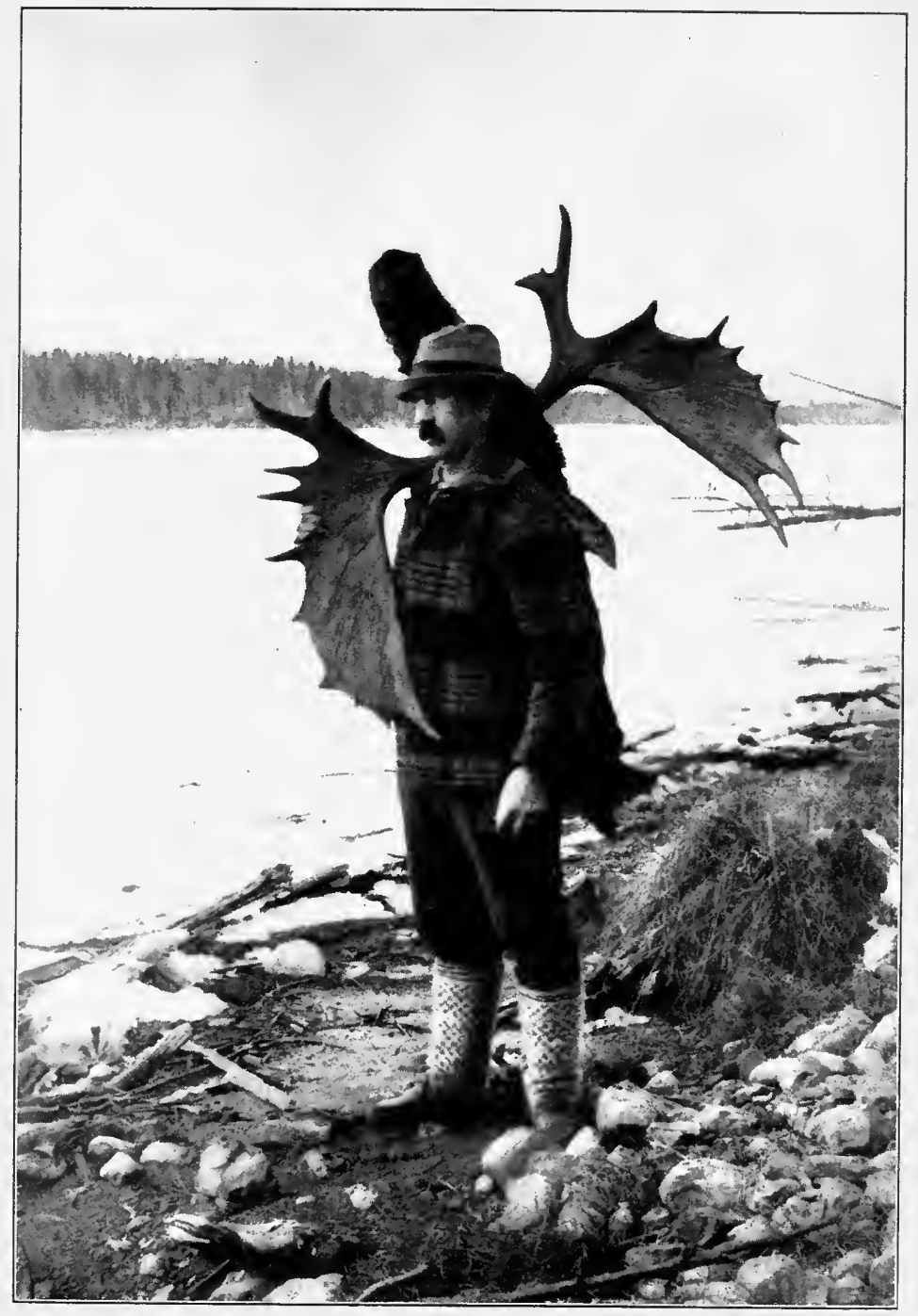

A Guide and a Trophy

Showing Shoepacks and Leggings of the Eastern Woodsmen 

is frequently on low moist ground, the air is cold and damp, and exercise is out of the question.

For a moose-hunting trip in November a pair of woolen mittens, with a separate place provided for the trigger finger, will be found desirable. They will occasionally be equally useful in the calling season.

Minor Accessories.-The smaller deer are generally taken out of the woods with their jackets on. The size of the moose, however, and the difficulties of transportation, have resulted in many entire carcasses being left for the bear and other carnivorce to devour at their leisure, the head and hide of the moose alone being taken from the woods, or perhaps only the head. If the hunter is provided with from six to ten yards of cheesecloth, and several strong burlap bags, he will be prepared to protect the meat from flies, if the weather is warm, and will be able to take out of the woods the hind quarters and perhaps other portions of the meat. By this means he will avoid the odium that attaches to the "head and hide hunter." Blowflies as late as October are likely to lay their eggs on freshly-killed moose meat. I have seen in the second week in October crawling evidences that such eggs had hatched on dressed moose 
meat which had been killed less than three days before by a woodsman who had neglected to include cheesecloth in his outfit.

In the calling season a thermos bottle, to supply a drink of hot tea at the calling stand without building a fire, will be appreciated. Some hunters seek to supply warmth by carrying a flask of liquor. But hot tea will kill more moose than cold whisky. "If you are one of those fellows who will use rum when you're calling," said a sportsman I once met,- -and it sounded as if it was the beginning of a temperance lecture,- " if you will use rum, take a thermos bottle with hot tom-and-jerry in it. I do!" A second thermos bottle, with hot tea for breakfast, will be useful if one tents at the calling stand, a mile or two from the main camp, to be ready for the daylight call.

Among minor articles which may well be included in the kit is a six-foot steel tape. It will save guesswork when a pair of antlers is to be measured, or other dimensions taken. The lack of such a measure is responsible for many of the absurd exaggerations with respect to spread of antlers and height at withers which have intruded into the literature of the moose, and which have brought into question the veracity of the writers. Thoreau's umbrella (!) and the boat's painter, 
with which he measured a cow moose which his companion killed, yielded results which the author of The Maine Woods was compelled in candor to repudiate after he had reduced them to feet and inches.

A thermometer in November will aid in forming a judgment whether the rain is likely to turn to snow, and whether the snow is likely to be crusted after a thaw.

In Nova Scotia and some portions of New Brunswick, as well as in the remote Northwest, there are many broad barrens, across or alongside which the moose travel from cover to cover. When hunting in such places a field glass will be found useful.

The equipment for a moose hunting trip, aside from the articles here enumerated, will not differ essentially from that with which the deer hunter in the early fall would provide himself. 


\section{CHAPTER VIII}

\section{HEADS AND HORNS}

If one would look for the most ancient existing antlers of the American moose--antlers acquired by the hunter and not by the geologist-he would probably find them in England. Queen Elizabeth made a large collection of trophies of the chase from all parts of her dominion. It was displayed in the "Horn Room," near the Great Hall of Hampton Court Palace, and was noted as one of the finest collections of game heads in the kingdom, where such collections have always been highly prized. Officials in the transatlantic colonies were charged with the duty of furnishing for the royal collection such specimens as the American forests could supply, and five sets of moose antlers obtained in America at that time, and given places in the collection, may be seen by the present-day visitor to Hampton Court.

After Henry VIII.'s great palace ceased to be a royal residence, the Horn Room collection was I66 
scattered through the different halls and apartments of the vast structure. The moose antlers were given the places of honor on the wall of the Great Hall, over the dais on which a succession of British sovereigns dined on the occasion of state banquets. They are in a distinguished company of trophies, representing the aristocracy of English game animals of three hundred years ago.

European collectors, distrusting the skill of taxidermists, often resort to the wood carvers when having the horns of animals mounted for exhibition. Most of the specimens now displayed in European collections consist of the horns with a portion of the skull attached-in many cases the entire skull-the head-skin being thrown away. The older and choicer specimens of antlers are often attached to finely carved wooden heads, the deep color of which preserves the appearance of the real scalp. The wood carvers of Europe in past generations have had many times to reproduce the head of the red deer, and rarely the head of the European elk. Accordingly I was not surprised a few years ago to see that the five sets of moose antlers in the Great Hall at Hampton Court were mounted on carved heads of Cervus elaphus, the European kinsman of the American 
wapiti. It was not the first time in European collections that I had seen a similar hybridization in preparing trophies for exhibition.

The old pensioner, for years custodian of the Great Hall, would not believe that such liberties had been taken with natural history in the royal collection of horns.

"Did you ever see an American moose?" I asked.

"No, sir."

"Or a European elk?"

"No, sir."

I showed him a photograph of a moose head.

"Upon my word!" said the old man. "I wouldn't have believed it!"

I am almost sorry that I called his attention to the case of nature-faking in the group of heads which were under his care. To shake his faith in the complete authenticity of every specimen in the royal collection was too closely akin to undermining his faith in the inviolability of the British Constitution.

Without a ladder, and an assistant, I could not measure the Hampton Court antlers, but recently I have had measurements made by representatives of Rowland Ward, Limited (the London taxidermists), with the following results: 


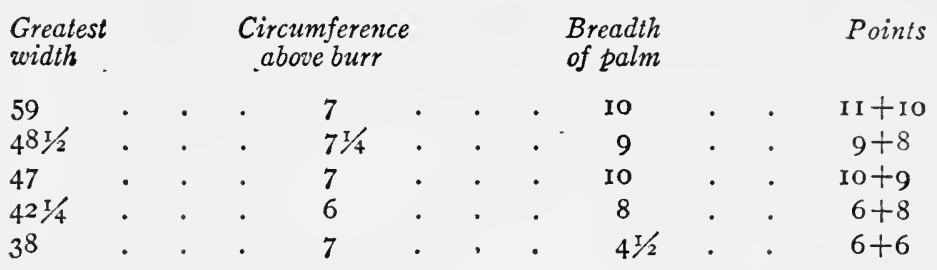

According to these figures the antlers at Hampton Court Palace include some very fair specimens, but they are inferior to many taken in recent years in the territory which consticuted the British colonies of America in the seventeenth century. If they were fairly representative of the good heads of their time, it is to be assumed that the deterioration by reason of subsequent hunting has been local rather than general.

It is a noticeable fact that while standards are constantly being advanced in the breeding of horses and cattle by the selection of the best strains of blood, there is likely to be deterioration with respect to wild game. The reason is not far to seek. Laws which permit killing only the older bulls, in the case of moose, together with the sportsman's natural desire to secure specimens having superior antlers, have left the breeding to the inferior members of the species.

This deterioration in some quarters is making" marked progress. In Europe it has been observed for centuries; in America it is only of compara- 
tively recent date that the increased interest in moose hunting as a sport has brought it to attention. At the great International Sportsmen's Exhibition in Vienna in rgro there was sharp contrast between the choicest red deer heads of the present day and the fine heads brought for exhibition from the palaces and royal hunting lodges of various countries, where they had decorated the walls since the sixteenth and seventeenth centuries. Indeed, for the purposes of prize awards, no heads of earlier date than 1848 were considered.

In Maine the rapid increase in the number of moose during the last decade of the nineteenth century, a result of effective legal protection begun in 1883 , has been followed by a noticeable decrease in the size of antlers, owing to the increased activity on the part of sportsmen. Maine is suffering from being easy of access, and from being separated by broad areas of farm land from other and wilder portions of the moose's range. Thus new blood cannot easily be introduced, as needed to maintain a high standard in the physical characteristics of the animals.

On the forehead of the bull calf one can feel two knobs underneath the skin. These knobs become a pair of spikes six or eight inches long in the 


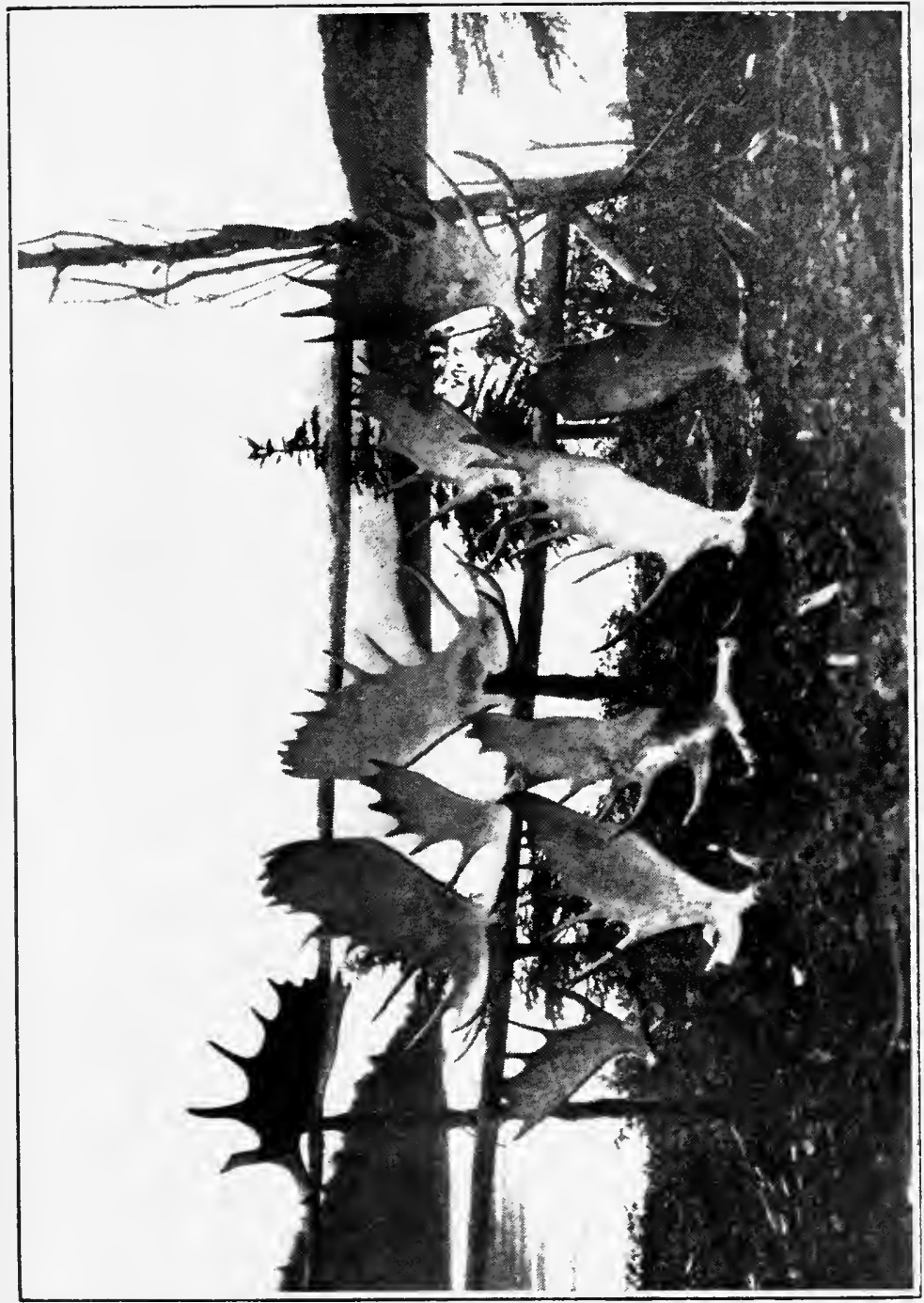

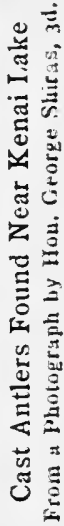



yearling. As a two-year-old the same moose would have two points on a side, and he would be known as a "crotch-horn." The three-year-old usually has three points on a side, and a small palm appears, while in the four-year-old the antlers assume the adult form, but of small size. After the moose is three years old the age can be only approximately estimated from the antlers. At about seven years of age the bull is in his prime. His antlers have now attained their full development.

The antlers of the crotch-horn are not dropped until about April. Each subsequent winter the antlers are shed earlier, and by the time the bull reaches his prime they are dropped by the last of December or early in January. One often wonders why he so rarely finds in the woods an antler shed in some previous season. Those which are found are usually mutilated, having been gnawed by the mischievous woods mice or by porcupines. Many, too, are dropped in swampy country, where the weather causes early decay. ${ }^{\mathrm{I}}$

The new antlers begin to grow late in April. At first the growth is very slow, but as summer advances it becomes exceedingly rapid. The

× Hon. George Shiras, 3 d, in the National Geographic Magazine for May, I9I2, pp. 450-454, 460-463, describes a rich harvest of moose antlers which he found on the ground in the Kenai Peninsula. 
growth is completed in about three months. During this time the drain on the vitality of the bull is great. The "velvet," the soft skin which carries the blood-vessels needed in the rapid growth of the antlers, finally dries and peels off, leaving the horns white and bare. ${ }^{2}$ The peeling of the velvet is assisted by the wearer of the newly-grown antlers. Woodsmen in the moose country are familiar with the frequent sight of saplings worn bare of bark by bulls anxious to rid their new fighting weapons of the ragged disfiguring skin. ${ }^{3}$

Early in September, when the rutting season is about to begin, the last of the velvet has generally been rubbed off, and the moose's antlers, as yet undamaged by contests with rivals, are turning a deeper brown. His coat is now unusually dark and glossy, and he stalks through the woods in the pride of his greatest strength as if clad in a wedding garment. Contests between bull moose take place only in the brief season of the rut.

${ }^{2} \mathrm{~A}$ valuable service for zoōlogy will be performed by one who, having access to a captive adult bull moose, will make a series of photographs at weekly intervals, showing the animal's horns during the spring and summer months while the horns are growing. An even greater, though more difficult, service would be performed if a series were made showing the same animal in the fall annually from calfhood to old age.

3 The maturity of the antlers seems to be attained somewhat later at a high elevation. Mr. Shiras, writing of moose in the southern portion of the Yellowstone National Park, nearly eight thousand feet above the sea, says: "As late as Oct. I not half the bull moose had their antlers free of velvet." (National Geographic Magazine, July, 1913.) 


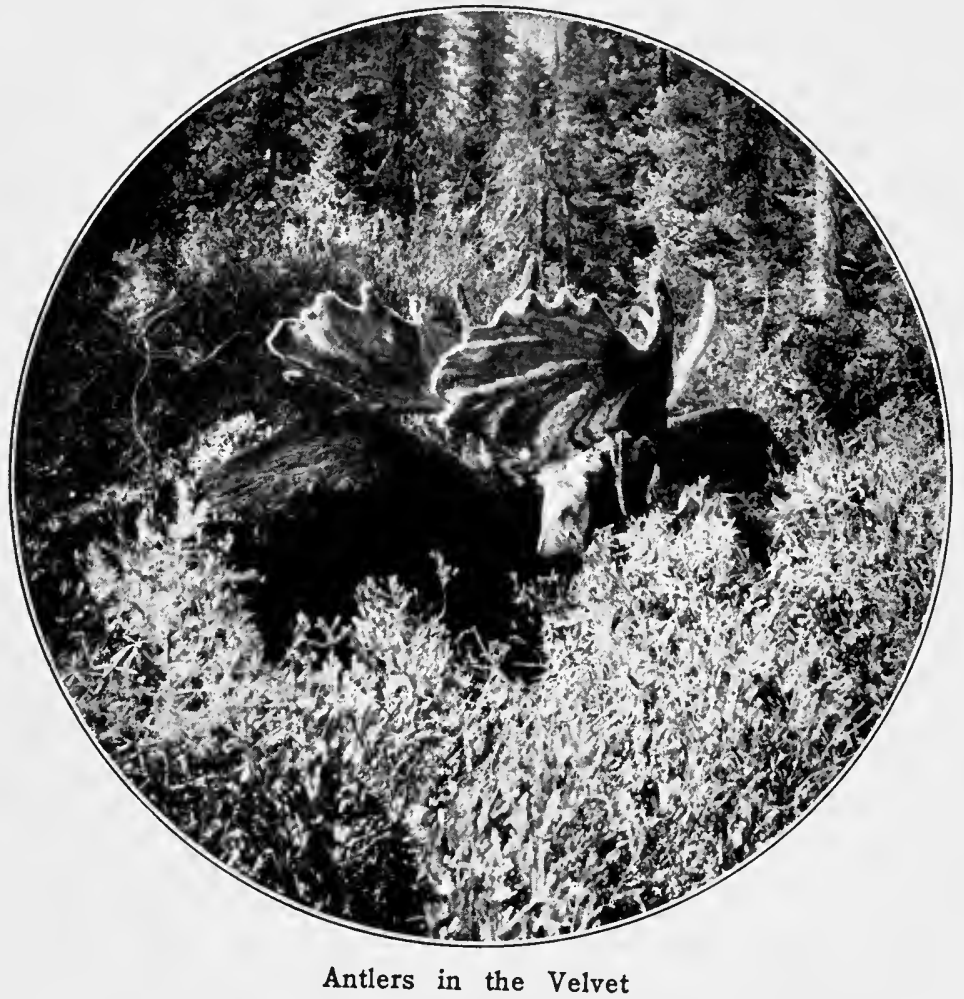

This moose was shot by Carl Rungius neal North Pole River, N. B., September 2 r, 1907. He was a very old bull, and came in answer to a call. The antlers spread only forty-two inches. The drawing opposite page 193 shows the antlers after the velvet was removed. 

Single prongs of the antlers are often broken in these mad onslaughts, but the main beam is sufficiently elastic to withstand any sort of shock without fracture.

Moose live to be eighteen or twenty years of age. After the bull has passed his prime the antlers are usually of lighter color, and, owing to the lower vitality, are dwarfed and imperfect, though the body may continue to increase somewhat in size. Accordingly one should not expect a record-breaking head if he kills a moose of record-breaking stature. The coat of the moose, too, loses its glossy brilliancy in old age, and the color becomes a brownish gray.

The antlers are closely associated physiologically with the season of mating. The horns attain their full growth in the summer, and then the velvet is rubbed off, leaving the prongs bare and sharp, just as the rutting season begins. Without his antlers the bull in his prime would enjoy little advantage over the three-year-old or the infirm old-timer with stunted horns. But with massive sharp-pointed fighting weapons, the most perfect specimen is able to drive off weaker antagonists -and thus, in the process of natural selection, the blood of the next generation should show greater 
vigor than if the physical weaklings enjoyed the favors of the females on equal terms. The rutting season over, however, the antlers are soon dropped as a useless incumbrance.

It is probable that the character of the available food at the time when the antlers are growing affects the season's growth to a greater extent than is generally supposed. It is certain that in a given district the average size of antlers is much greater some years than others. A Russian writer claims that food rich in phosphate of lime and in tannin tends to promote the fullest development of antlers. Knowing this fact those in charge of elk in Russian preserves and parks regulate the food of the animals accordingly. If they have produced any record-breaking antlers by this means the fact is not recorded. It is said too that the quantity and quality of the water furnished the elk are important factors in antler-building.

European writers who have had opportunity to study moose in restricted preserves, observing the same specimens year after year, assert that individual peculiarities are seen in successive years in the cast antlers of certain moose, observable in spite of the yearly increase in size and number of points.

The possession of antlers by cow moose is exceedingly rare, but is not altogether unknown. 

Edward R. Alston writes: "Mr. Dresser informs me that in New Brunswick he once examined in the flesh a female moose with well-developed bifurcated antlers." 4 In most cases where females of the deer family have been found with antlers they have been barren. The presence of antlers in the case of fertile female caribou, however, is very frequent.

Moose antlers are much less frequently found interlocked than those of the common deer. The best known example of interlocked horns is preserved in the National Collection of Heads and Horns in New York. The spread of one pair is $691 / 2$ inches, while the other measures 62 inches. An Indian hunter on the Kenai Peninsula was attracted to the battlefield of the big animals by the noise of the combat. When he arrived on the scene one moose had a broken neck, and the other was vainly struggling to free himself from the unwelcome incumbrance. The Indian killed the survivor, but was unable to separate the antlers. $^{5}$

Dr. Josselyn, who told of moose horns the tips

4 Proceedings of the Zoölogical Society of London, 1879, p. 298. Lewis Lloyd (Scandinavian Adventures, vol. ii., p. 95) says that at the castle of Aschaffenburg, in Germany, there is the horn-cranium of a female elk having eight points.

5 Harper's Weekly, Jan. I5, I9Io. 
of which were sometimes "two fathom asunder," was not the first, nor the last, to exaggerate in this respect. Lahontan, writing from Canada under date of July 8, I686, tells of the "great flat horns" of l'orignal, "which weigh as much as 300 pounds, and even as much as 400 , if we may believe those who have seen them." If the young baron had seen the horns himself possibly he would have added a few pounds. At any rate, he saw the Falls of Niagara, and tells us that "ce Saut a sept ou huit cens piez de hauteur"-an exaggeration of more than 400 per cent.

As recently as 1890 , in The Big Game of North America, - the introduction to which was written by Judge Caton,- - a writer mentions a western Wyoming moose-head having a spread of 102 inches. "The largest pair of antlers I ever saw," he tells us, "was taken from the head of a moose that was killed in the Teton Basin, near the head of Snake River. ... They measured, from tip to tip, $81 / 2$ feet." 7 It is a pity that trophies like this are never preserved. How they would dwarf the largest heads that any of us ever saw, or ever will see, even in the greatest museums!

There is no ground for disputing the dimensions

${ }^{6}$ Nouveaux Voyages dans l'Amérique Septentrionale (The Hague, I703), vol. i., p. 74 .

7 Page 24. 



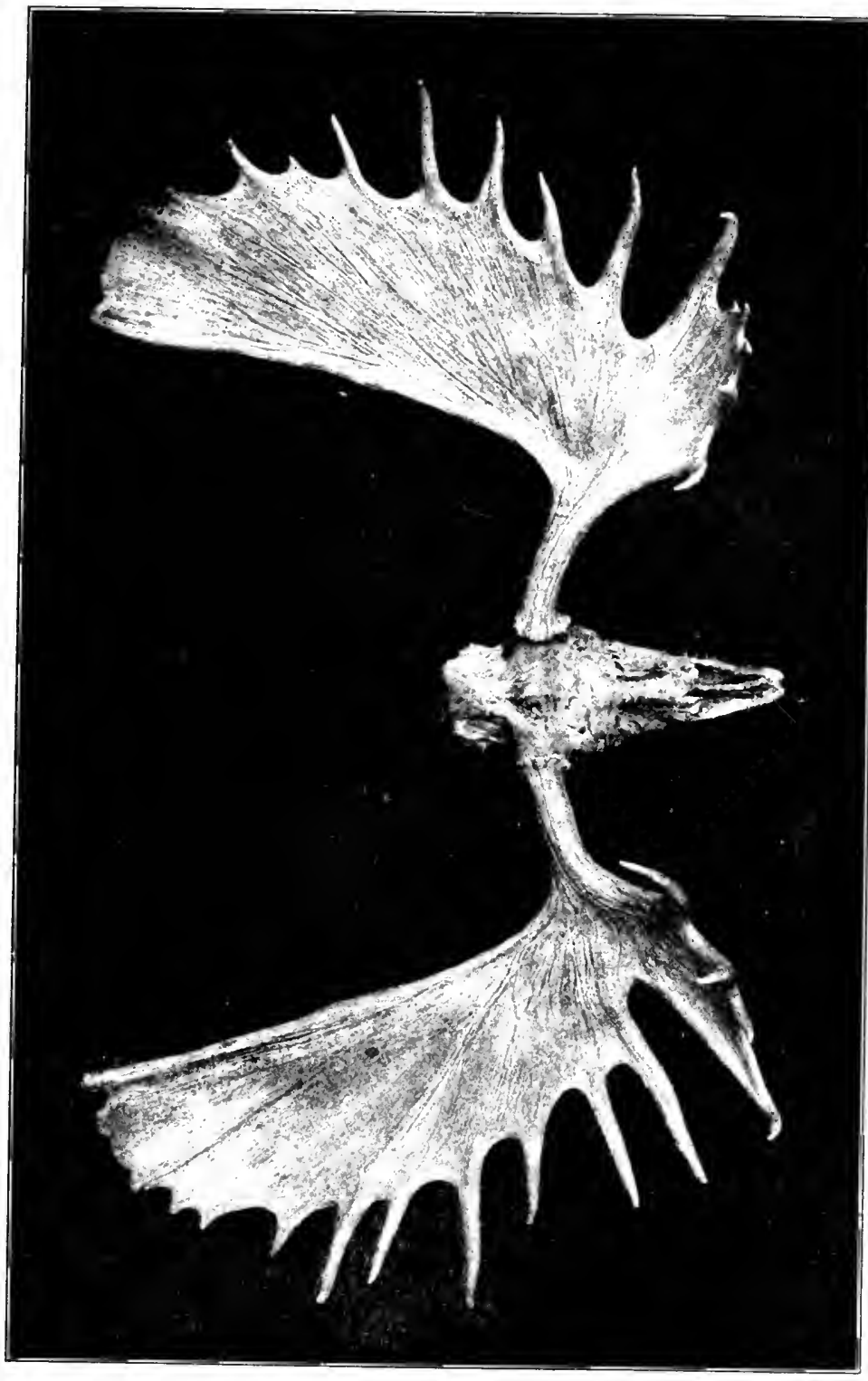

$r$ 
of large antlers in the museums, or of those which are in private possession and available for inspection. Heads which are described as exceeding these dimensions, but which are not to be found if one wishes to subject them to the tape-measure test, may be dismissed as apocryphal. If one found a diamond excelling the Koh-i-noor he would not throw it into an ash barrel, and if one found moose antlers spreading eight or ten feet he would hardly leave them for the hedgehogs to devour in the woods.

In view of the wide variety observable in antler formation and development, and the "freak" antlers everywhere found, it is impossible to define certain types as characteristic of certain localities without admitting exceptions in such numbers that the types are of little value or importance.

The largest and finest moose-heads which the world has seen have come from the Kenai Peninsula of Alaska. In general characteristics the Alaska antlers are massive and broadly palmate, with a large number of points. They are often marked by a secondary palmation of the brow prongs at right angles to the main palmation.

The moose-head showing the widest spread of antlers yet secured was taken on the Kenai Penin- 
sula in 1899. This head is now in the Field Museum of Natural History in Chicago. The spread is $78 \mathrm{r} / 2$ inches, and it has 34 points. The maximum breadth of palmation is 18 inches, and the palmation in places is $2 / 8$ inches in thickness. With the dry skull the antlers weigh about 92 pounds. ${ }^{8}$ It is said this head was brought into Kenai by an Indian, who claimed to have found the moose drowned in Kenai River. At that time the spread measured 8I inches. ${ }^{9}$ The curator of zoölogy at the museum states that the Indian was arrested by a game warden, who perhaps distrusted the story of the accidental death of the moose, and that the head was confiscated. It found its way into the hands of a taxidermist in Chicago, who sold it to the museum.

A finer pair of moose antlers, but with less spread, was shot by A. S. Reed, an Englishman, on the Kenai Peninsula in I900. This head is now in the Reed-McMillan collection, in the possession of the New York Zoölogical Society. Its superiority lies in its broader palmation and greater number of points. When killed, Mr. Reed's

${ }^{8}$ See Life Histories of Northern Animals, by Ernest Thompson Seton (N. Y., 1909), vol. i., pp. 158, 161. Seventh Report N. Y. State Forest, Fish, and Game Commission, 1901, p. 233.

9 Big-Game Shooting in Alaska, by Cap. Charles R. E. Radelyffe (London, 1904), p. 60. 


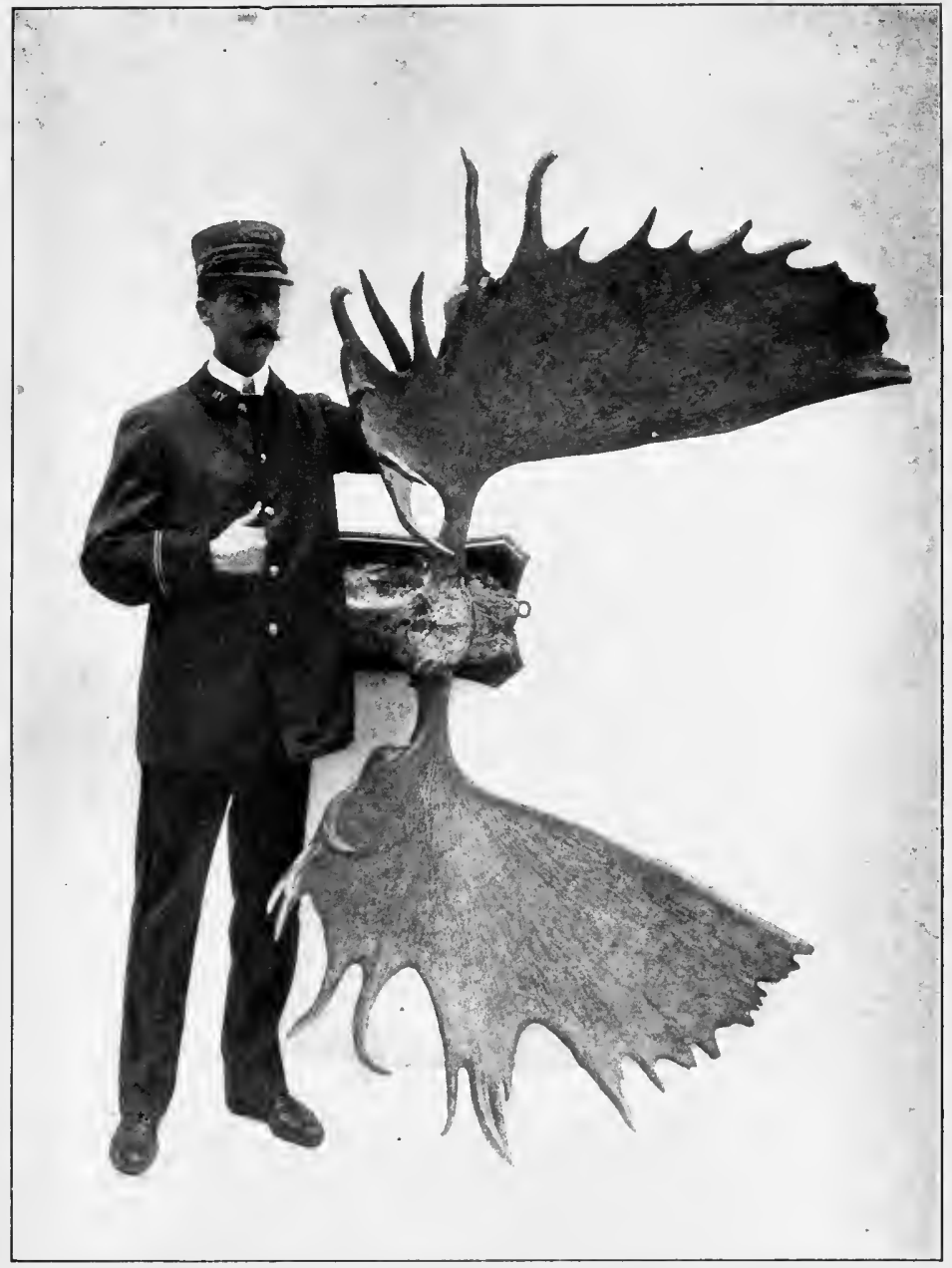

The Reed-McMillan Antlers

(Reproduced by Permission of the New York Zoölogical Society) 

moose had a spread of $761 / 2$ inches, but in drying the antlers shrank to 75 inches. The right antler has 19 points, with palm 18 inches in width, and beam 9 inches in circumference above the burr. The left antler has 23 points, $215 / 8$ inches maximum palmation, and $10 \mathrm{I} / 4$-inch circumference of beam. ${ }^{10}$

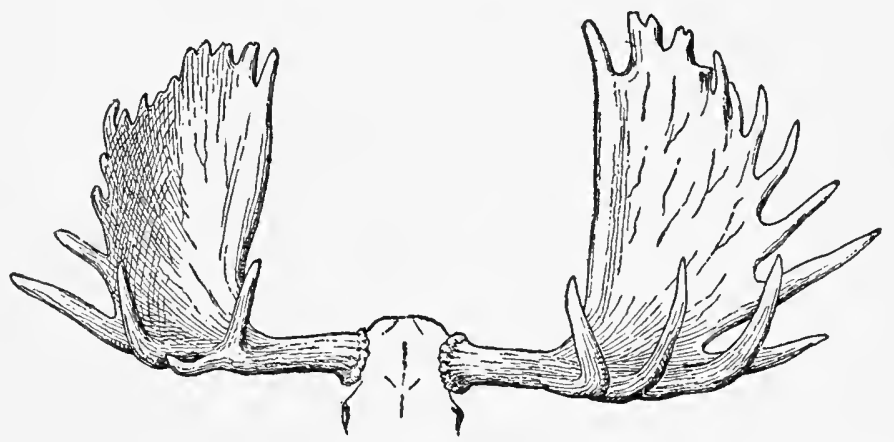

The Niedieck Antlers

A head from the Kenai Peninsula, given to the New York Zoölogical Society in I9 I by Clarence H. Mackay, spreads 76 inches. This head has $\mathrm{I} 3+\mathrm{I} 5$ points, and the palmation reaches $2 \mathrm{I} / 2$ inches in width. The circumference of beam above burr is Io inches.

At the International Sportsmen's Exhibition in Vienna in I9Io the first prize for moose-heads

ro The National Collection of Heads and Horns (N. Y., 1907), p. 48. The so-called "National Collection" belongs to the New York Zoōlogical Society, and is displayed in the offices of the Society at the Bronx Park, but it is not open to the public. 
was given for one from the Kenai Peninsula shot by Paul Niedieck Oct. 9, I906. The spread of these antlers is given by Rowland Ward as $771 / 2$ inches, but this was probably the measurement before the skull and antlers had dried. This head was exhibited at the Thirteenth German Exhibition of Antlers, held in Berlin in January, I907. It was then described as having a spread of 193 centimeters, or 76 inches, and weighing, with skull_(but without lower jaw), 77 pounds. ${ }^{\text {Ir }} \mathrm{H}$. J._Elwes, -writing in Country Life (London, July 30, I9I0), "gives the spread as 74 inches, and this agrees with my own measurement, made in Vienna. There are $\mathrm{I} 7+\mathrm{I} 6$ points. ${ }^{\mathrm{I2}}$

In Yukon Territory of Canada two exceptionally good moose-heads were secured by a party of Peel River Indians in the autumn of I9I2. The Indians were hunting mountain sheep in the Canadian Rockies, at the head of Peel River, within 100 miles of the Arctic Circle, and were above the timber line, when they encountered the moose. Jarvis Mitchell, one of the Indians, killed the larger one with his rifle. The antlers

"Die Jagd, Berlin, Feb. 3, 1907. Niedieck describes the capture of the moose in his book Kreusfahrten im Beringmeer (Berlin, 19 )7), p. 2 I9.

${ }^{2}$ The best European elk-head shown at Vienna measured 53 inches in breadth of spread, and had 23 points. See Chap. xvir. 
spread $74 \frac{1}{2}$ inches when freshly killed, and they have IO+II points. The palmation is $10 \mathrm{I} / 2$ inches wide and the circumference of beam is $8 \mathrm{I} / 2$ inches. This is believed to be the widest spread to which Yukon can lay claim. The other moose,

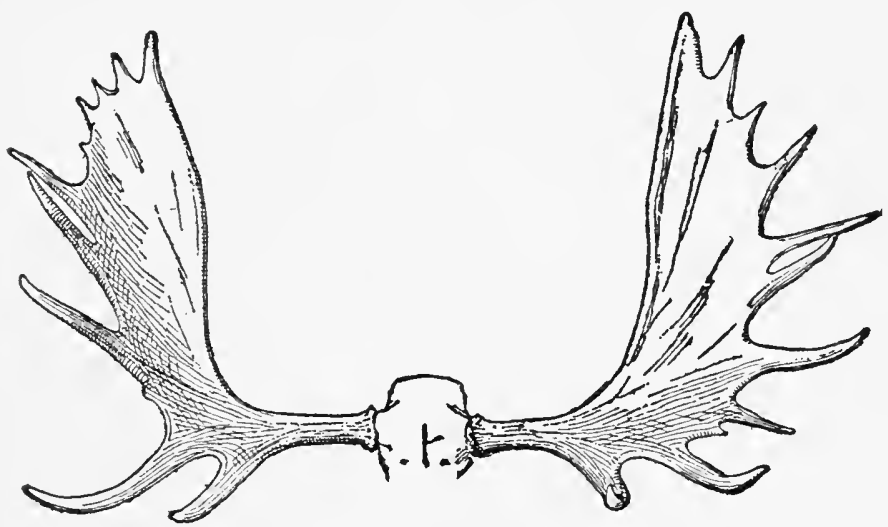

From the Canadian Rockies

killed at the same time by another of the Indians, had massive antlers spreading 63 inches, with I $8+$ I 5 points, and with blades 16 inches wide. ${ }^{\mathrm{I} 3}$ These heads are in the possession of William Norton, a taxidermist, now living in San Francisco, but formerly of Dawson. A. P. Engelhardt, Terri-

${ }^{3}$ The present owner gave the weight of this second pair of antlers, with skull, including the lower jaw, as ror $1 / 2$ pounds. He said the Indians hauled the heads to Dawson on a toboggan, a distance of three hundred miles. In their opinion the moose had gone up the mountain to escape from wolves. 
torial Secretary of Yukon, writes that he has seen the heads, and that the statements regarding them are known by him to be correct.

Frederick C. Selous shot a moose on the north fork of Macmillan River, in Yukon, Sept. I8, 1904, with antlers spreading 67 inches. The number of points was $17+21$; palmation 20 inches; circumference of beam $81 / 2$ inches. Mr. Selous had been a successful hunter of all kinds of African game, but he called this "the finest hunting trophy that has ever fallen to my rifle."

British Columbia's best moose-head, according to information furnished by the Provincial Game Warden, is perhaps one measuring $65 \frac{1}{2} 2$ inches, secured by R. R. McCutcheon of Iowa. A better pair of antlers was found in northeastern British Columbia in the autumn of 1914 by S. Prescott Fay of Boston. The two horns had lain on the ground since the previous winter, a mile or more. apart, and the second was picked up a week after the first was found. When held side by side, in about the normal position, the spread measured 67 inches. They have $12+13$ points. A. S. Reed, whose collection of heads is now in New York, is said to have killed a moose in the Cassiar country some years ago with antlers measuring more than 70 inches, but the head was left in 


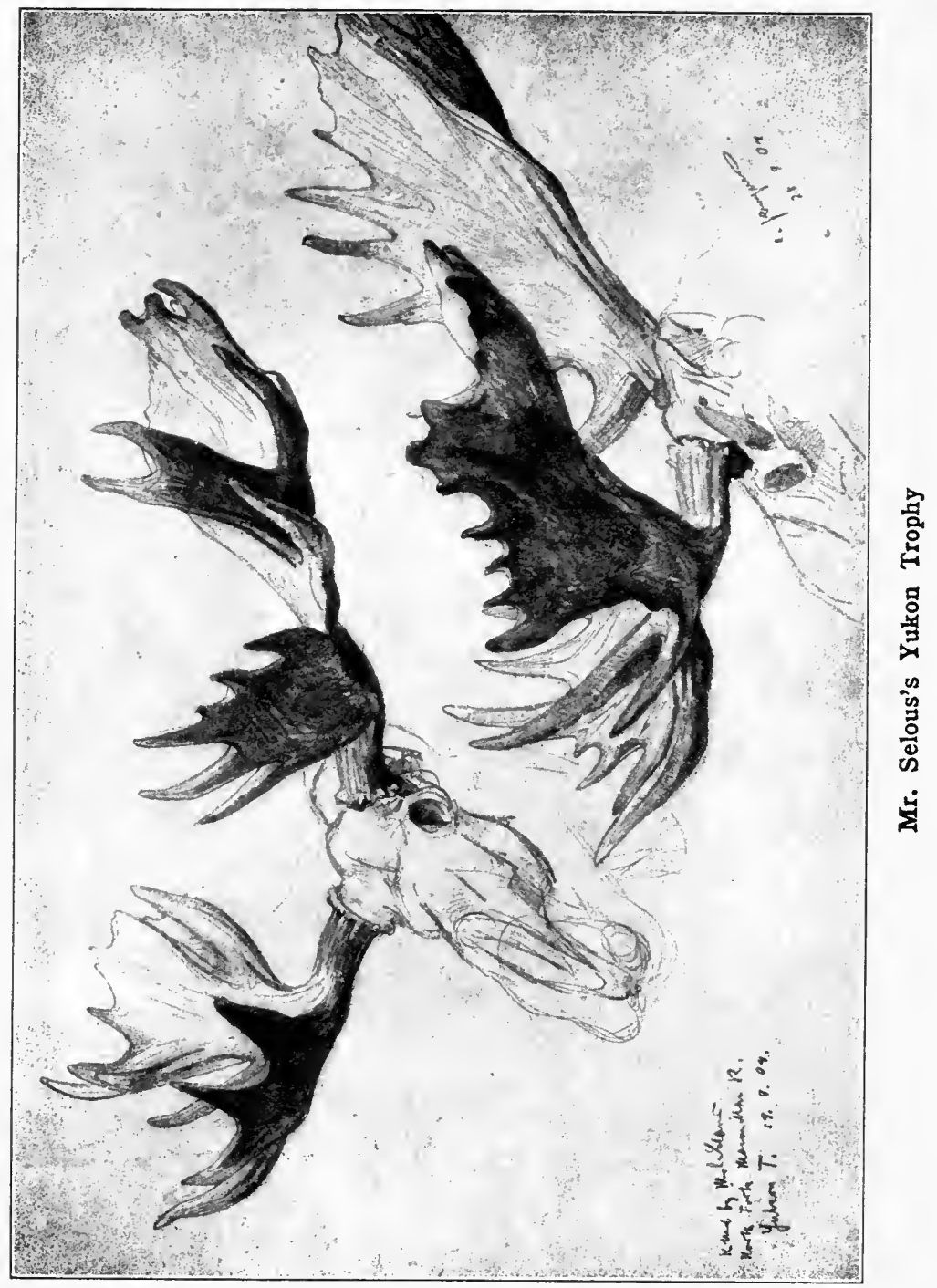



a cabin for the winter, and was destroyed with the burning of the cabin. Many good heads are found in the northern part of the Province, but in the Rocky Mountain region of southern British Columbia and the neighboring section of the United
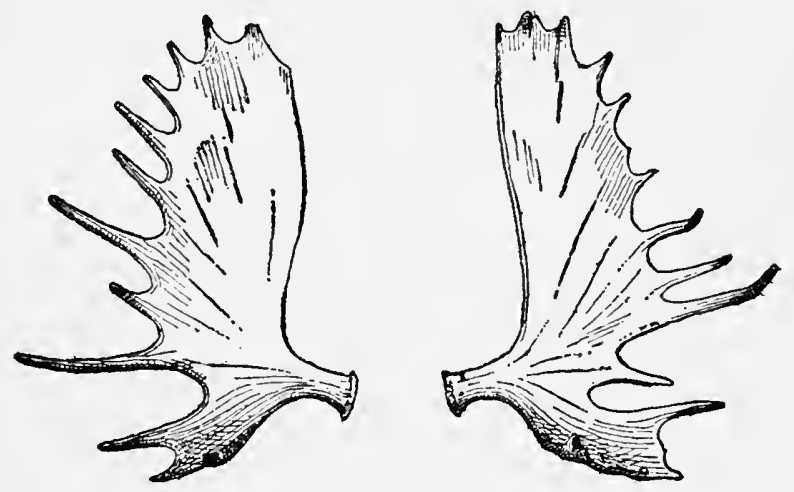

Cast Antlers Found in British Columbia

States moose are few in number and the heads very inferior.

Alberta has produced a number of moose-heads with antlers spreading about 65 inches. Benjamin Lawton, Chief Game Guardian, writes that a head with a spread of 66 inches, taken in the northern part of the Province, is the widest of which he has any knowledge.

The best Manitoba moose-head, in the opinion of the Chief Game Guardian of the Province, is one measuring 6I inches taken in I9I I sixty or 
seventy miles north of Winnipeg. It has $18+20$ points and the maximum palmation is 15 inches. It is now the property of $\mathrm{E}$. IV. Darby, official taxidermist to the Manitoba Government. ${ }^{\text {I4 }}$

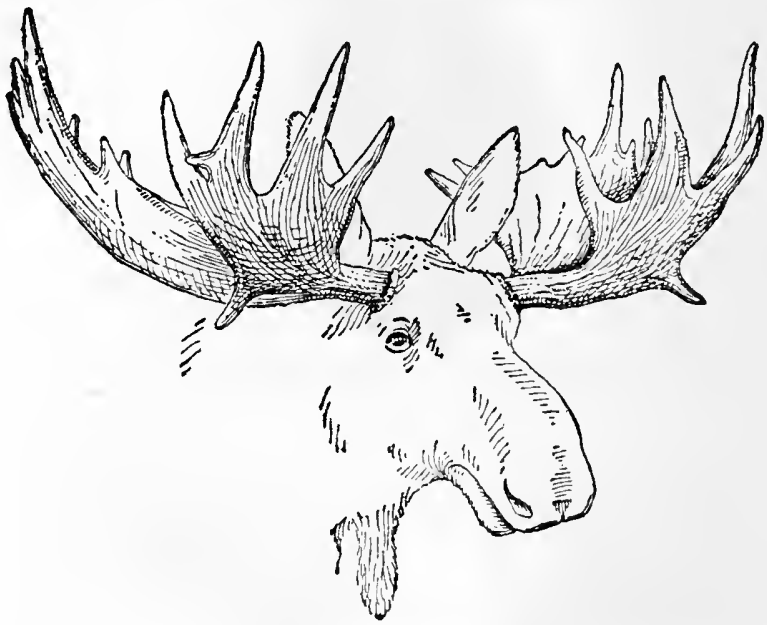

Minnesota's Best Head

In Minnesota a symmetrical 64-inch head fell to the rifle of $\mathrm{H}$. C. Percival, a Canadian, in the late '9os. This is probably the Minnesota record. The moose was killed in St. Louis County.

Ontario's best moose-head was taken at Round

14 Ernest Thompson Seton's Life Histories of Northern Animals (vol. i., p. 155), quoting Rowland Ward's Records of Big Game, mentions a 65 -inch Manitoba head belonging to Otho Shaw. Early editions of Ward's Records described this head as having 24 inches' breadth of palm and $13+14$ points, but in the latest edition of the work the head is not mentioned. The authenticity of the data seems to be in doubt. 


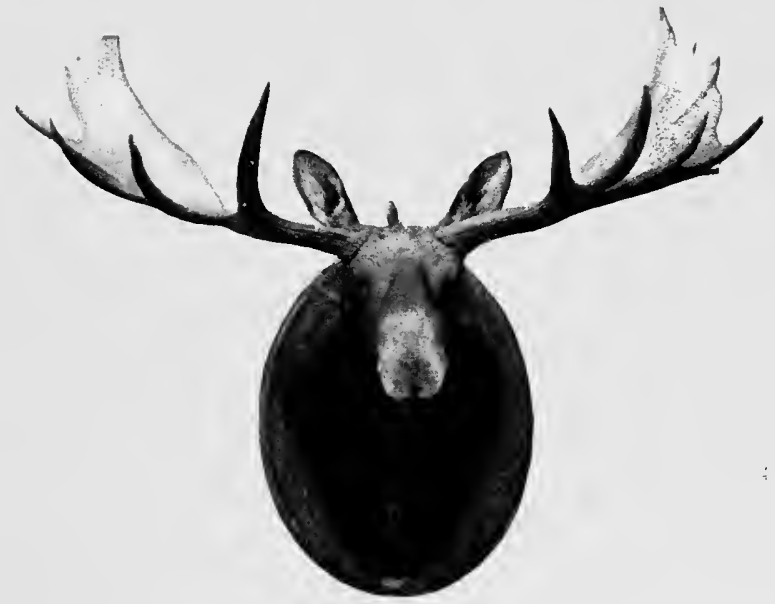

A Former New Brunswick Record

(See page 187)

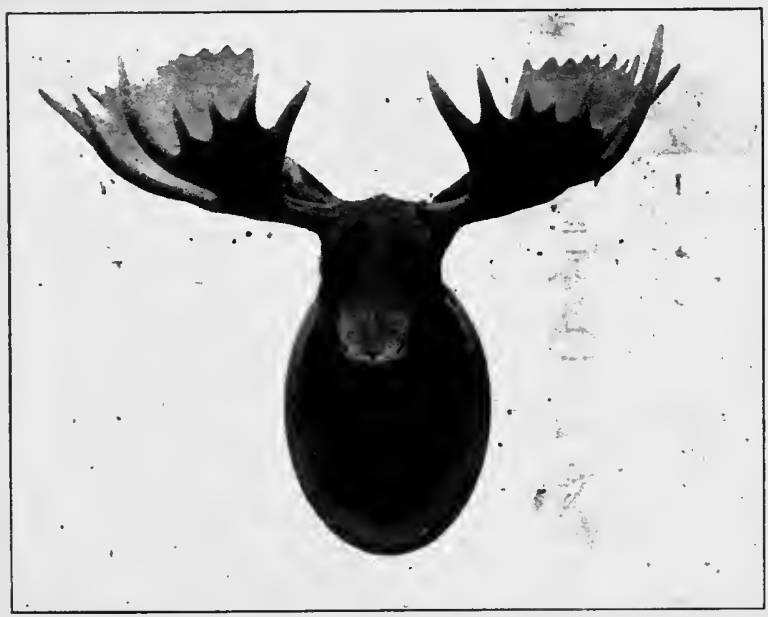

Manitoba's Best Head 
Lake, in the Temagami Forest Reserve, late in October, I9Io, by M. A. Kennedy of Toronto. Mr. Kennedy writes that the present spread of the antlers is $7 \mathrm{I}$ inches. When freshly killed the spread was 72 inches. The head has $I I+I 2$ points, the greatest breadth of palmation is $14 \frac{1}{2}$

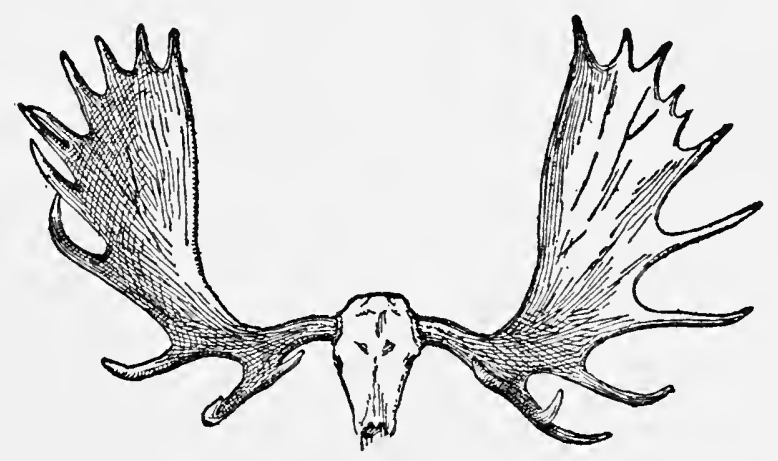

A 71-Inch Head from Ontario

inches, and the circumference of beam $81 / 4$ inches. Mr. Kennedy shot the moose from a canoe, at about 200 yards' distance. Nine bullets from a .303 Lee-Enfield rifle took effect in the neck and shoulders before the animal fell.

An Ontario moose-head was described and illustrated in Recreation for August, 1902, the antlers of which spread 67 inches. There were $16+x 7$ points, and the palmation reached 19 inches in breadth. The moose was shot on the 
Demoine River, a tributary of the Ottawa, by Batiste Seymo, an Indian. The head belonged to W. H. Rowley of Ottawa.

Quebec's record for spread of antlers is believed to be $691 / 2$ inches. These antlers have $14+13$ points, the maximum palmation is 12 inches, and the circumference of beam $8 \mathrm{I} / 2$ inches. The head was secured by the late Lewis Mills Gibb of Brooklyn, N. Y., Oct. Io, I906, and is now in possession of his widow at Bay Shore, Long Island. The moose was killed in the Caughnawana Club preserve in Pontiac County, near the Ontario border. This was Mr. Gibb's first moose, and it was secured in less than twenty-four hours after his hunt began.

The best Quebec head described by Ward spread, when thoroughly dry, $62 \mathrm{I} / 2$ inches. It has $14+13$ points, the breadth of palm is 14 inches, and the circumference of beam $71 / 2$ inches. This head was secured by Col. John Caswell, a Massachusetts sportsman, October I2, 1903. He was hunting on the Patapedia lakes, Rimouski County, and the moose was brought from a distance of about two miles by a call in the early morning. Two shots from a .375 Holland double rifle, loaded with cordite, effected the capture.

The Maine record for spread is said to be 62 , 


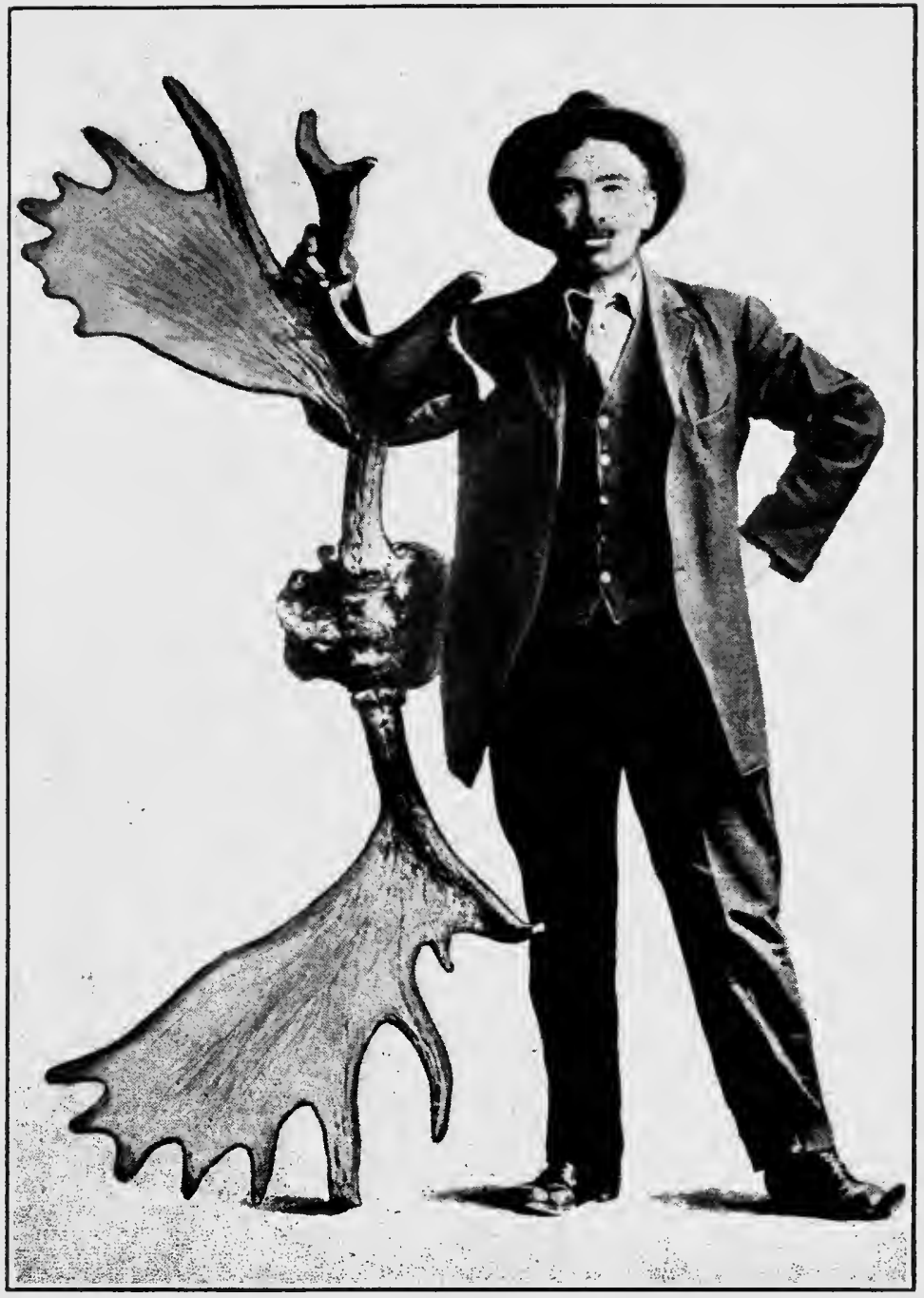

A New Record for New Brunswick Spread, $715 \% 8$ Inches

(See page 359) 

inches. The taxidermist's record of the time when the moose was killed, and the place, together with the number of points and other data, was destroyed in the great fire which visited Bangor in I9I. Rowland Ward describes 6I American moose-heads in his Records of Big Game. These include two from Maine with spread between 57 and 58 inches. Maine taxidermists, when requested recently by the Game Commissioners to furnish information of the best heads which had passed through their hands, reported mounting a number of heads having a spread of from 58 to 60 inches.

A head which once held the New Brunswick record for spread was secured by Dr. Walter L. Munro of Providence, R. I., on the Nepisiguit River, October I2, I907. The breadth was $68 \mathrm{I} / 2$ inches when killed. It has $7+$ Io points, and 16 inches' width of palmation, with heavy beams.

Antlers measuring 67 inches in breadth were secured in New Brunswick in October, 1898, by F. H. Cook of Leominster, Mass. They have shrunk by the drying of antlers and skull to $651 / 4$ inches. They have $13+$ ro points.

Stephen Decatur, now of Kittery Point, Me., killed a moose on the Serpentine branch of the Tobique River, N. B., Sept. I I, I897, whose antlers 
spread 661/4 inches. Mr. Decatur writes that the present spread is $65 \frac{1}{4}$ inches. The number of points is $13+12$; greatest palmation $131 / 2$ inches.

A pair of moose antlers presented to Edward

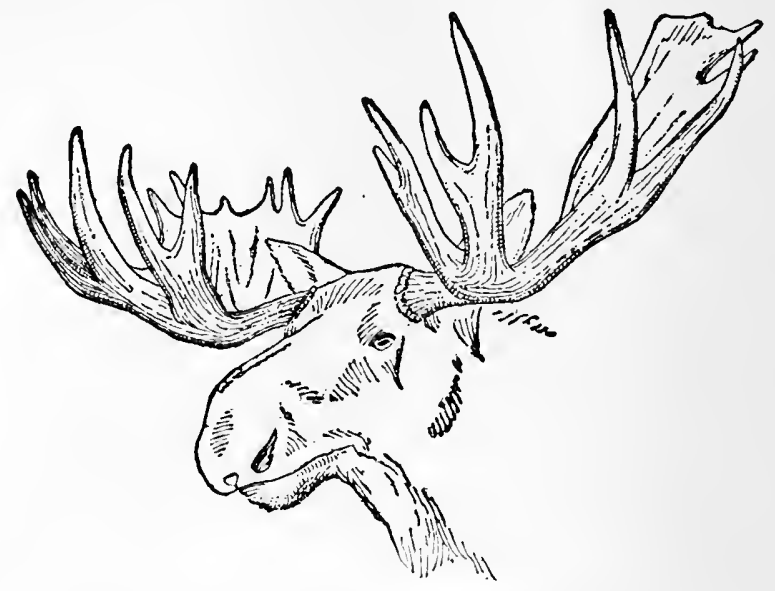

F. H. Cook's New Brunswick Moose-Head

VII., when, as Prince of Wales, he visited Canada in 1860 , was long considered as having the widest spread recorded for New Brunswick, Maine, or Nova Scotia. The antlers were taken in the Canaan River country of New Brunswick by Sir Harry Burrard, and measured 62 inches. ${ }^{15}$ The weight of antlers and dried skull was 56 pounds. ${ }^{16}$

$\times 5$ With Rod and Gun in New England and the Maritime Provinces (Boston, 1897), p. 266.

${ }^{6}$ Dr. A. Leith Adams, Field and Forest Rambles (London, 1873), p. 89. 
Several noteworthy moose-heads have been subjects of dispute, New Brunswick and Maine both claiming them. This was the case with a head formerly in the possession of the late Albert Bierstadt. It spread $641 / 4$ inches, and had more than 30 points. This moose was killed in 1880 near the international boundary, but probably on the New Brunswick side. ${ }^{17}$ The Province has occasionally failed to receive the credit to which it was entitled for a notable head, by reason of the fact that the sportsman shipped his prize to a foreign taxidermist for mounting.

Nova Scotia, like Maine, will perhaps lose credit for its best moose-heads, owing to lack of authentic data regarding trophies secured many years ago. The Chief Game Commissioner of the Province has recently instituted inquiries with a view to securing such information as can now be obtained on this subject. He writes that an Indian called Lone Cloud in the fall of 1903 secured a head in Guysboro County spreading $631 / 2$ inches, with 34 points.

A head with antlers spreading 59 inches, and with 34 points, was taken in Guysboro County in rgro by L. G. Ferguson of Westville. This

${ }^{17}$ See Seventh Report N. Y. State Forest, Fish, and Game Commission, p. 232. 
head is now in possession of the Chief Game Commissioner.

The chief points to consider in comparing moose antlers are (I) breadth of spread, (2) number of prongs, (3) breadth of palmation, (4) circumference

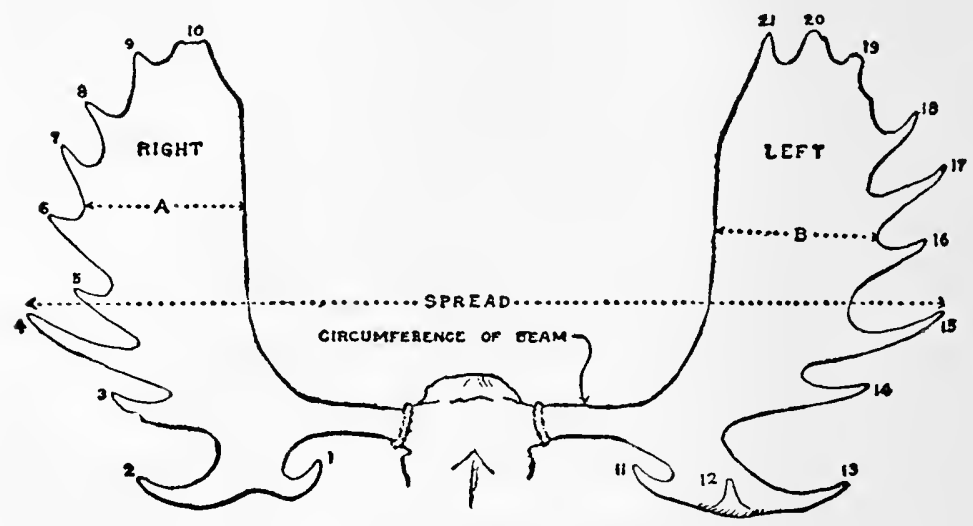

Measurement of Moose Antlers

of beam. In the accompanying diagram spread is measured from prong No. 4 on the right antler, to prong No. 15 on the left. An inch or two would be added if the measurement were made from No. 4 to No. I7, but diagonal measurement is manifestly unfair. These antlers have ten points on the right side and eleven on the left. Sportsmen are sometimes tempted to count two points at Io, and another at the angle just below Io; they would perhaps credit also two points at 20 , and another 
between I8 and 19. These may, however, be dismissed as places where independent prongs might have developed, but unfortunately did not. Maximum palmation may be measured at either A or B. "Circumference of beam" is the minimum circumference of the heavier beam.

The usual standards of comparison in the case of moose antlers are very insufficient. Many sportsmen consider spread the only test of quality; some merely count points. But spread has in some instances been increased by splitting the skull with a saw, and mounting the two halves at a fictitious angle. Furthermore, Hornaday's definition of a "point" as "any pointed projection of sufficient length that a watch can hang upon it without falling off" leaves much to be desired, in view of the variety of shapes which prongs assume. A better single test would be weight, but this is impracticable when the antlers are not removed from the skull, or when a head is to be judged after being mounted. A test, sometimes resorted to in Germany in the case of smaller animals, of displacement in water, would be excellent, save for the difficulty of ascertaining the displacement with precision, in the case of antlers so large as those of the American moose. ${ }^{18}$

${ }^{2} 8$ " $U p$ to this time, moose antlers have been ranked by their spread alone, but I think that is a mistake. In my opinion, area of palmation should be regarded a; the leading feature, for it is that which is most 
A. combined system of scoring, in which credit would be given for various qualities, would have many advantages. An imaginary normal head might be scored as follows:

Points of

Spread (transverse, not diagonal), inches $\quad . \quad$. . $\quad .47$

Number of points $\quad . \quad$. $\quad . \quad . \quad . \quad . \quad 2 I$

Width of palmation, inches, right $81 / 2+\operatorname{left} 9 \mathrm{I} / 2$. . . . I8

Circumference of beam (doubled), inches, $61 / 2 \times 2$. . . I3

Breadth of blade is important, as well as breadth of spread. Breadth of blade and circumference of beam are in most cases indicative of weight and mass, points which in this country are popularly ignored.

I was in a New Brunswick camp one day when a sportsman came in and reported killing a moose whose antlers spread fifty-four inches.

"How many points?" I asked.

He had not taken the trouble to count.

"Did they have good blades?"

They had not been measured.

A few days later I took the trail near which the moose, waiting for the tote team, was lying. The

impressive in moose antlers-far more so than wide spread and narrow 'shovel."'-Hornaday, The National Collection of Heads and Horns, p. 48. But area of palmation is not easily measured. 



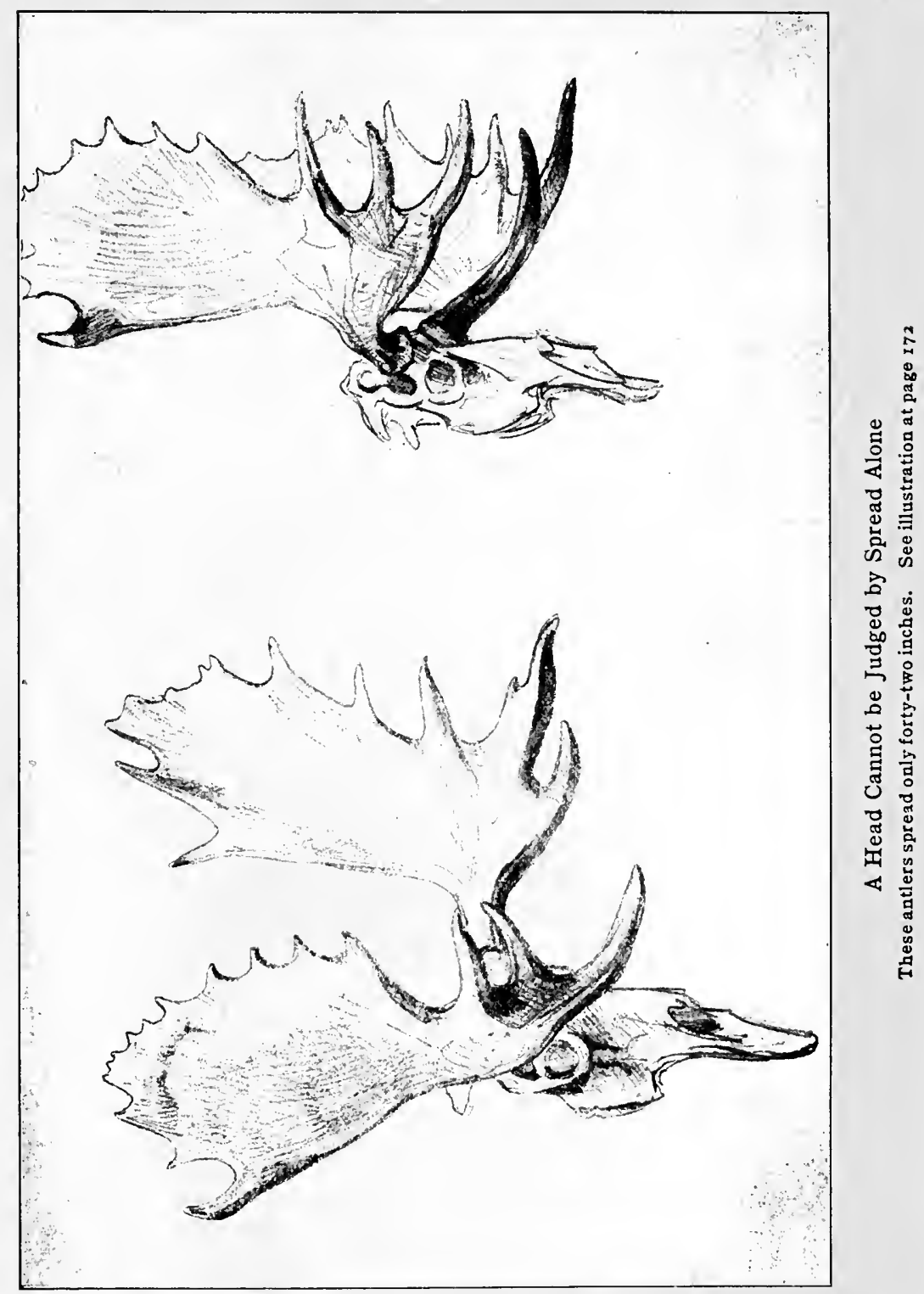


memoranda in my notebook make it possible for me now to "score" the head, as follows:

Spread

Points

Palmation $7+8$

Beam 53/4 $\times 2$

\begin{tabular}{ll}
$\cdot$ & 54 \\
$\cdot$ & 17 \\
$\cdot$ & 15 \\
. $111 / 2$ \\
\hline $97^{1 / 2}$
\end{tabular}

The antlers were comparatively light and thin, and the spread extraordinary under the circumstances. If brought into comparison with normal heads, with credit given for symmetry, this head would suffer still more in the scoring.

John B. Osborn of Boston killed a moose in Maine in 1892 the present spread of whose antlers is only 39 inches. But in all respects except spread it would rate as superior to either of the heads above described. It may be scored as follows:

Spread

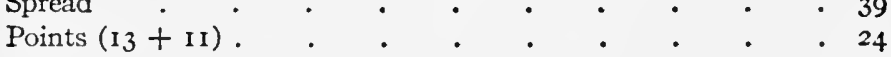

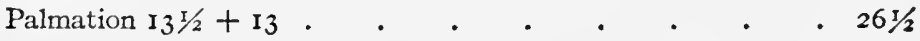

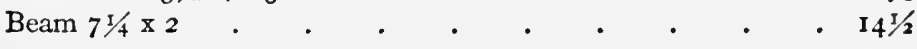

104

The broad blades and strong beams of these antlers, as well as the number of points, certainly entitle them to more consideration than is measured by the spread. 
Scoring by such a system as here suggested may be done by anyone, anywhere, and the relative merits of moose-heads be thus intelligently compared. For the purposes of an exhibition, in which judges were to make an award, it might be well to add not exceeding some stated number of points, say ten, for symmetry and general appearance. Thus the "freak" head would lose some of the unfair advantage which it sometimes enjoys.

Some candid taxidermists assert that the scalp, or head-skin, of a moose or caribou cannot be so cured and mounted that one can safely guarantee that it will not crack-chiefly around the muzzle. It is certain that many mounted moose-heads have thus become unsightly. This trouble is likely to be caused by the skin repeatedly becoming moist, and afterward drying. Salt in the skin, or clay or plaster in the manikin, tend to draw moisture from the atmosphere, and thus atmospheric changes will cause the scalp to stretch and shrink, the skin finally breaking away from the manikin, and cracking. Hence the use of salt, clay, and plaster should be avoided. For the same reason the skin should be attached to the manikin by a medium in which water is not used as a solvent.

The skill of European taxidermists in devising 
novel and artistic ways in which to mount trophies of the chase is far beyond that of the commercial taxidermists in America. Antlers in Europe are not infrequently mounted on carved wooden heads-and it is easy to find skilled wood-carvers, artists in their line, in most European countries. Such carvings are more attractive than inferior or damaged taxidermy, and the owner need apprehend no deterioration-for a few hundred years at least. Much more frequently European antlers are mounted with the entire skull, but without the scalp, or with a section of the frontal bone connecting the horns, on an elaborately carved shield. The skull is blanched, and on it is usually painted the date of killing, with the owner's monogram-surmounted in most cases by a coronet of some sort, for the European big-game hunter usually belongs to the landed aristocracy.

Few animals have heads so lacking in grace and beauty as the moose. The sacrifice of beauty, accordingly, will not be great if the sportsman accepts a suggestion from German or Austrian source and has his moose antlers mounted on a standard such as is often employed in mounting the antlers of the red deer in the Continental countries. The trophy thus becomes a decorative 
I 96 THE AMERICAN MOOSE

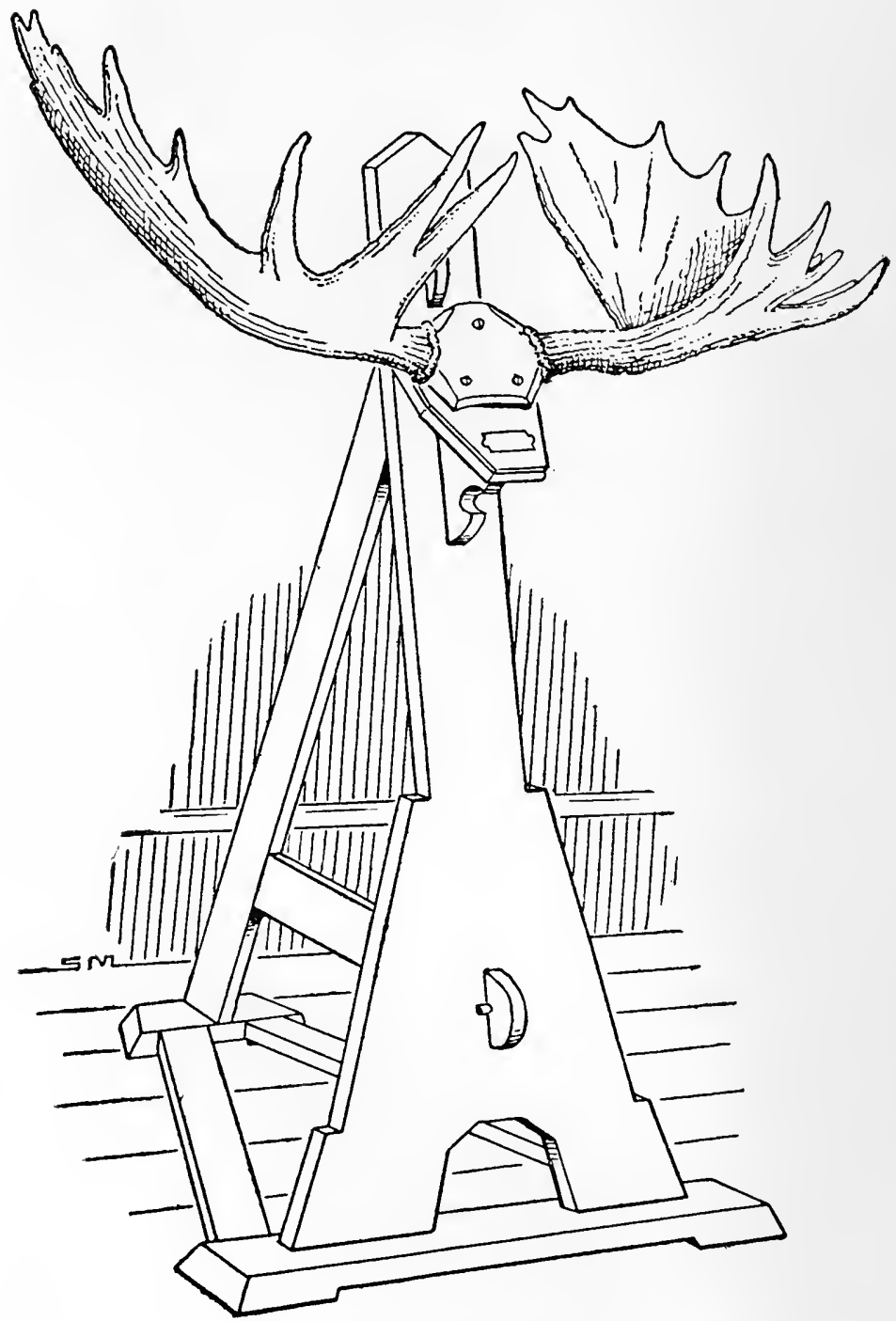

A Hungarian Design 
article of furniture appropriate for the hall, while avoiding the hazard of a cracked scalp with its disfiguring blemish.

A new era in American taxidermy will dawn with the completion of the "African Hall" lately planned by Carl E. Akeley for the American Museum of Natural History in New York. ${ }^{19}$ This hall will offer a valuable object lesson in artistic taxidermy. Meanwhile the studio at the museum, in which the specimens are being prepared, is serving as a school for training workmen in the new methods which have been developed to insure permanence and lifelike effect. Mr. Akeley brings to his work the skill of the sculptor, the naturalist, and the sportsman, as well as that of the practical taxidermist, and he brings enthusiasm at the same time. He has no secret processes, but welcomes all who are seeking information with a view to promoting the advancement of the art.

Mr. Akeley believes in bark tanning. A moose scalp thus cured, scraped down to uniform thickness, and free from acid and salt, will be soft and pliable, and sufficiently tough. "Akeley's standard manikin" is constructed of wire cloth, and a composition made of paper, glue, whiting, and linseed oil. These are the component parts of

"See the American Museum Journal, May, IgI4. 
papier-maché and putty, and the composition has the stability of the former with the plastic quality of the latter. The modeling of the manikin will of course be a severe test of the taxidermist's skill. The skin should be applied to the manikin dry, and should be held in place by means of shellac, or by some cement which is free from water. Such work requires time and care, and is bound to be more expensive than when the ordinary commercial methods are employed, but it is permanent, and if the modeling is skillfully done it is lifelike. Heads thus mounted represent the farthest advance in taxidermy yet reached. This process is new, and its details have not been published. Mr. Akeley is not engaged in commercial work, but he will willingly answer any questions from sportsmen or taxidermists.

There are various minor by-products of a successful moose-hunting trip, in addition to the familiar and cumbersome inkstands, made from the forefeet of the animal. Napkin rings may be made from the main beam of a stray antler which is not to be mounted with the head for a wall decoration. The beam should not measure less than $6 \frac{1}{2}$ inches in circumference if it is to be used in this way. Such a napkin ring, which has been 
on my table daily for several years past, has of ten called to mind an episode of the New Brunswick woods. I had shot a bull with a spread of 55 inches, and on returning the next season to the place where the tragedy was enacted discovered, two or three hundred yards away, the "house" of a bear trap, which had been set the previous year. For

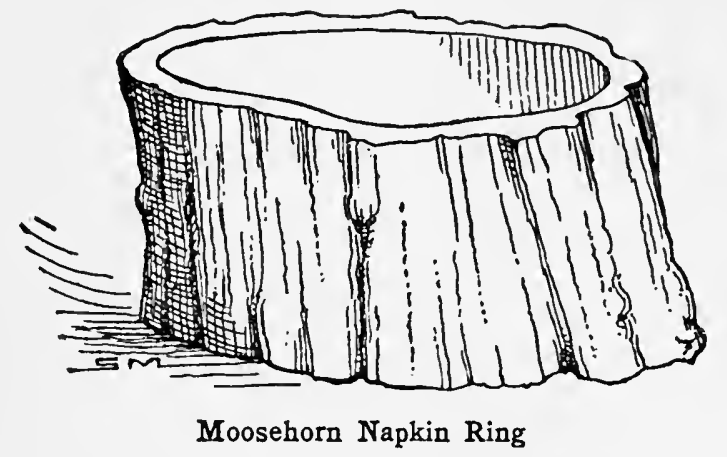

bait the trapper had used the head of a moose which had been found dead in that vicinity. These abandoned antlers were blanched on one side by the elements, and were of moderate dimensions, but they were sufficiently heavy to make several napkin rings. The horn was still as hard as ever, and took a high polish on the inner surface.

A section of a beam which is too small for a napkin ring may be made in to a paper-weight, or it may be used as the holder for a small glass ink-well. 
Single horns, or portions of them, may be made into wall brackets or candelabra. An antler which has been dropped by its wearer in the woods is usually found whitened by exposure to the weather. The dark color may be restored by the use of a strong solution of permanganate of potash, applied with a brush. This solution has a purplish color. It is not a pigment, however,

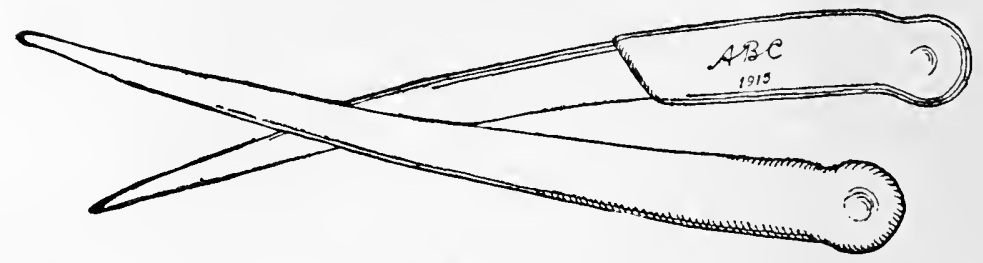

Dewclaw Bones of Moose

but merely an oxidizing agent, and restores to the horn the original brownish color

Two excellent paper cutters are carried by every moose in each fore leg. They are the dewclaw bones, and lie side by side just above the dewclaws. They are usually seven or eight inches long. They are easily removed, dried, cleaned, and polished. If necessary the cutting side may be filed down to a little sharper edge. The dewclaw bones in the hind legs are too short to be of use. A handle made from a prong of a moose or deer horn may be attached to the paper cutter. The 
best handles, however, are provided by a deposit of silver on the bone itself. The silver is nearly $1 / 10$ of an inch thick, and conforms to the shape of the bone. It covers about a third of its length, at the larger end. The silver is deposited by an electroplating process, but few electroplaters or silver workers know the secret of making such handles.

Like others of the deer family, but unlike domestic cattle, the hair grows upward from the nose of the moose- a fact which should be borne in mind when brushing the dust from a mounted specimen. The hide of the moose is much inferior to either buckskin or caribou skin when tanned. It is porous and easily stretched. When made up into moccasins woodsmen say that it begins to leak twenty-four hours before it begins to rain. ${ }^{20}$ Moose skins are valueless for rugs owing to the brittleness of the hair. ${ }^{2 r}$

10 Oil-tanned moose skin - the oil, however, being extracted in finishing - is very pliable, and a strand a quarter of an inch in width will support a tensile strain of 250 pounds. It is easily soiled, and is not adapted even for house moccasins. The gambier or bark process of tanning yields a skin with less elasticity, and much less tensile strength, but the skin makes good moccasins for house wear. A moose hide which will weigh when green, with the hair, fifty pounds, will weigh when tanned about twelve pounds.

${ }^{21}$ If the head of a moose is to be mounted it should be removed from the body without many hours' delay, or else the entrails should be drawn. If the carcass is left undrawn overnight the scalp is likely to be worthless in the taxidermist's hands, and the flesh will be unfit for food. 
Moose-hock moccasins, tanned with the hair on, are often used in the woods in winter. The skin is peeled down without being cut open, and sewed up at the lower end. The hock joint forms the heel. They are seamless, except at the toe, and are excellent for snowshoeing.

Until the European trader came the Indian was dependent on his own resources for supplying all the articles required to meet his simple needs. Various animals contributed to furnish him materials for clothing, weapons, and domestic utensils, but the moose furnished more than any of the others. Bernard R. Ross, long in the service of the Hudson's Bay Company in the Mackenzie River district of the Canadian Northwest, has given an account of the animals which are useful from an economic point of view to the various Indian tribes of that region. ${ }^{22}$

"The uses to which the various parts of the moose are put are many," he says. "The hide supplies parchment, leather, lines, and cords; the sinews yield thread and glue; the horns serve for handles to knives and awls, as well as to make spoons of; the shank bones are employed as tools to dress leather with; and with a particular portion of the

22 Canadian Naturaiist and Geologist, vol. vi. (1861), pp. 433, 437. 
hair, when dyed, the Indian women embroider garments."

The leather is serviceable for tents, clothing, dog harness, etc. "The capotes, gowns, firebags, mittens, moccasins, and trousers made of it," writes Mr. Ross, "are often richly ornamented with quills and beads, and when new look very neat and becoming. . . . To obtain thread the fibers of the sinews are separated and twisted into the required sizes. The moose furnishes the best quality of this article, which is used by the natives to sew both leather and cloth, to make rabbit snares, and to weave into fishing nets. Sinews can be boiled down into an excellent glue or size." 


\section{CHAPTER IX}

MOOSE MEAT AS FOOD

IT would be difficult to measure the service performed by the moose and other species of deer in the era of exploration and colonization in furnishing food for those who left the markets far behind, and sought to accomplish the conquest of the wilderness. The era of colonization past, however, venison becomes for most merely a convenient dish to vary an otherwise ample bill of fare. But venison is much more than a convenience in an emergency. It is adapted for use as food in a wide variety of ways, and is highly esteemed, when properly cooked, whether broiled, roasted, stewed, or otherwise prepared for the table.

According to the dictionaries, venison is the flesh of any animals of the deer kind. Moose meat, and the flesh of the Virginia deer, the caribou, and the elk, are alike venison. Each of these has its partisans among epicures, some giving one the 204 
highest place, others favoring another. Moose venison resembles beef in appearance, and also in flavor, more closely than the other sorts of game do, while the venison of the smaller species of deer is more frequently likened to mutton. All have a flavor unlike that of domestic meat, however.

Venison deserves a higher place, with respect to dietetic value, than it commonly receives. "It is especially adapted to invalids, who require a nourishing yet easily digested food." ${ }^{\prime}$ A writer in the Scientific American several years ago gave an interesting table showing the relative digestibility of various foods. In this table grilled venison takes, with boiled rice and boiled tripe, the first place, the three dishes requiring only one hour for complete digestion. Boiled chicken, on the other hand, requires two hours for digestion, roast turkey, duck, and goose from two to $21 / 2$ hours, grilled beefsteak and mutton three hours, roast chicken four hours, and grilled or roasted veal five hours. ${ }^{2}$ In view of these facts it is to be regretted that so often moose venison is wasted, owing to the difficulty of transporting it from the remote place

I Prof. David E. Lantz, in Bulletin of the Biological Survey of the Department of Agriculture, issued Dec. 31, 1910, p. I4.

${ }^{2}$ Scientific American, July 17, 1909. 
in the woods where the hunt ended to the tables of the hunter and his friends hundreds of miles away.

It has been said that the same moose never furnishes a good head and good steaks, but this statement is not true. The meat of even an old moose, if in good condition in other respects, is excellent in flavor, and if kept for a sufficient time at a moderate temperature it will be tender. In the rutting season, and immediately after, the venison of any animal is not at its best, though I have eaten the steak of a bull moose killed on the second day of October that was as free from any rank flavor as meat killed eight weeks later. The carcass of an animal should be dressed promptly and properly, and the meat should be given a chance to become tender without becoming tainted. Disregard of some of these conditions is probably the cause of most of the prejudices against certain forms of game.

Moose meat may be kept indefinitely without injury in the freezing room of a cold-storage warehouse, and such establishments now offer their facilities to the public in most cities. The meat may be left frozen for months: when thawed its quality will be found unimpaired. Venison which 
has been repeatedly frozen and thawed, however, will be comparatively flavorless. On two occasions I have left large pieces of moose meat in cold storage for more than eleven months, but the steaks were as fresh and sweet when cooked as if the animals had been killed a single week.

A moose should be cut up, and the pieces wrapped in butchers' parchment paper and put in separate burlap bags, before refrigerating, so that portions may be taken out without thawing, and without the difficulties incident to cutting frozen meat. If it is necessary to cut a frozen hind-quarter of moose in the cold-storage warehouse a carpenter's hand saw should be used. It could not be cut with a knife. A meat saw would of course cut the bone readily, but it cuts the frozen flesh slowly, and it has so little "set" that the track of the blade is likely to be clogged by the particles of meat fiber freezing after the saw has passed.

Most failures in broiling or roasting moose meat are due to disregard on the part of the cook of the natural dryness of the meat. Like most venison moose meat is dryer than the flesh of domestic animals. The fat is indigestible and unpalatable, and should be trimmed off and thrown away, its place being supplied by pork or butter. 
A moose steak should be cut thick, and should be served rare, unless one's taste absolutely insists on more thorough cooking. If a wire broiler is used the wires should be well greased. The wire broiler will give good results if a hot coal fire, or a bed of hot hard-wood coals, is available. The surface of the steak should be seared quickly on both sides, to retain such juice as the meat contains, and with a slow fire this would be impossible. Do not season until the meat is done; then add pepper, salt, and plenty of butter. Serve hot, from a hot platter. If a piece of meat has hung a day or two too long to suit an over-fastidious taste, the gamy flavor may be corrected by adding a little jelly-any kind which is not sweet-and a dash of port or sherry.

In the woods glowing hard-wood coals are not always available when needed. Most woodsmen for this reason prefer pan-broiling for steak. The frypan should be kept exceedingly hot. This is easily done, even if the fire is of soft wood recently kindled, and a steak may be ready for the table long before a suitable bed of coals could be secured for grilling. The meat should be turned often. In pan-broiling none of the juice is wasted. A heavy castiron frypan is preferred to one of pressed steel, for it retains the heat better. 
Chops should not be cut and broiled with the bone, like mutton or the loin of beef, but the strips of sirloin and tenderloin should be cut out as fillets, leaving the bones for the soup kettle. The fillets should be sliced to the required thickness, and broiled as steak. If cooked with the bone, over a hot fire, the meat would be burned on the edges before that next to the bone was fairly warmed through.

For a roast the haunch is usually selected. It is best to remove the bone, though not necessary. The fire should be very hot, especially for the first few minutes, to sear the surface of the meat. Lay thin slices of fat salt pork on the meat, and baste often with the drippings. A gravy may be made from the juice in the pan, with currant jelly added. The time required for roasting will depend on the size of the roast, and the character of the fire. Serve hot.

An excellent French rule for a sauce for roast venison is as follows: Thicken the drippings slightly with flour; pour off and add a wineglass of good claret; heat without boiling, and serve hot.

Moose Stew.-Saw the marrow bones in pieces two inches in length; cut the meat in medium-sized pieces; add three slices of pork cut in quarter-inch 
squares, and three or four onions sliced; add pepper and salt, and a piece of butter as large as an egg. Boil three hours. Add three or four potatoes, quartered or sliced, in time to cook. When done add two or three tablespoonfuls of flour in a pint of water, stirring till it boils. For dumplings, use batter as for cream of tartar biscuit, put into the stew five or ten minutes before serving, according to size.

Small pieces of tender meat, too small for the broiler, may be utilized in pies-made as chicken pies are made-or in Hamburg steak, or in the chafing dish.

Moose Steak in Chafing Dish.-Take steak for three. Melt a piece of butter the size of an egg in a chafing dish. Put in the steak, and season it; when it is seared on the outside turn it over. Cook ten minutes, keeping the dish covered. Add a tablespoonful of port or sherry for each person, and a little currant jelly. Serve hot.

If preferred the wine may be omitted. In this case a tablespoonful of flour should be added. When the flour is cooked brown in the butter, add water to make a brown gravy. Dissolve in the gravy a tablespoonful of currant jelly. Serve hot, on toast.

A moose liver is fifteen or eighteen inches long, 
and nine or ten inches wide. It is the one part of the animal which is adapted for immediate use on the table. A dish of fried liver may be served for supper on the same day that the animal met his death. The liver of moose is highly appreciated by all who like the liver of any animal. It should be parboiled for a few minutes, and then sliced and fried with bacon.

The tongue of moose is not unlike beef tongue, and may be cooked similarly. Smoked, this was one of the favorite tidbits of the Indians, and it has found favor with many white men. "The Tongue of a grown Moose, dried in the smoak after the Indian manner, is a dish for a Sagamor.",

A writer in Audubon and Bachman's Quadrupeds of North America tells of hunters who would spread the uncooked marrow of freshly killed moose on bread, and eat it with relish as they would butter. The marrow is usually cooked, however, and in various ways. Captain Hardy tells of burying the marrow bones in hot ashes, and leaving to cook all night. ${ }^{4}$ Or they may be impaled on sticks and roasted before the camp fire. In this case, when the bone is burned so it can be easily split with a

${ }^{3}$ Josselyn, New Englands Rarities Discovered (London, 1672), p. 20.

${ }_{4}$ Sporting Adventures in the New World (London, 1855), vol. i., p. 258; vol. ii., p. 21 . 
knife the marrow will be sufficiently cooked. Perhaps the best use for the marrow, however, is to enrich the broth of a stew. Certainly a moose stew without this addition is likely to be thin and watery.

Moose feet, when cooked, closely resemble pigs' feet in character and flavor.

Prejudices on the part of intelligent people with respect to food survive longer than any other of the unreasoning whims which are handed down from a time when intelligence was lacking. The result has been a great economic waste, which often its victims could ill afford. Oxtails, it is said, were unknown and untried in France as an article of food until the Revolution, when a friendless aristocrat was driven by hunger to beg the tails of cattle from the refuse of a butcher shop. He made a stew to ward off starvation, and thus discovered oxtail soup.

The beaver's tail is not a switch to drive away the flies, like the tail of a horse or cow; nor a plaything to be chased, like the tail of a domestic cat; nor yet an utterly useless appendage, as in the case of most other animals. Like the moose's muffle the beaver's tail is an important bodily member, and does work which human hands often 
cannot equal in the architectural and engineering undertakings for which the beaver is noted. And the beaver's tail, like the moose's muffle, is a highly esteemed article of food among the epicures of the woods who have had opportunity to eat it. Both possess character and flavor more closely allied to the fat of the green turtle than to any other well-known dish. The author cordially recommends both from personal experience to all who can appreciate richness and delicacy in their food.

The suggestion that the "muffle" of a moose be eaten often causes the woodsman to inquire suspiciously, "What is the muffle, anyway?" When told that it is the nose and lip, his suspicion is likely to become violent antipathy. But the moose's muffle is not merely an olfactory organ: it is a member which is used as deftly as a man would use his hand in picking off twigs of considerable size from trees, the moose often reaching high in the air and breaking down the tops of saplings by this means. Like the beaver's tail it is a useful substitute for a hand, and like the beaver's tail it is the choicest tidbit which the animal can furnish for the table.

"The Nose is look'd upon as a great Dainty; I have eat several of them my self; they are perfect 
Marrow." Thus wrote Judge Dudley, son and grandson of Governors of the Massachusetts Bay Colony, in a monograph on the moose which was published in the Philosophical Transactions of the Royal Society of London nearly two hundred years ago. Audubon and Bachman in their Quadrupeds of North America ${ }^{5}$ also commend this dish. "The flesh is considered very good, especially the mouflon, which forms the upper lip, and is very rich, juicy, and gelatinous. This is cleaned and dressed in the same manner as calves' head." And "a military chaplain” (Rev. Joshua Fraser), writing of a dinner in an Indian camp on the upper Ottawa, thus describes a dish of muffle: "The crowning dish was that grandest of all dishes, moose mouffle. This is the immense upper lip and nostrils of the animal, and I have no hesitation in pronouncing it one of the most toothsome and savoury of all the dishes within the range of the gastronomic art. It is white and tender as spring chicken, yet firm and substantial as fresh beef, with a flavor combining the excellencies of both. I eat to repletion, yet was not sensible of any of that uneasy heaviness which generally follows a too hearty meal."

5 Vol. ii., p. 187 .

'Three Months among the Moose (Montreal, I88I), p. 26. 
The edible portion of the muffle comprises the fibrous flesh of the cheek, and the gelatinous prehensile upper lip. The cartilaginous nasal septum is of course not eaten. I have heard taxidermists say that the muffle cannot be saved for the table if the scalp is to be used in mounting the moose's head. And still a skillful taxidermist once removed the head-skin of a large moose for me, and saved three and a quarter pounds of muffle, including cartilage, but including also much of the rich flesh of the upper lip. This furnished for my table three quarts of thick rich stew-a dish which was greatly enjoyed by all who shared in it.

Probably the muffles of more than nine-tenths of all the moose whose heads are not saved for mounting are thrown away in the woods, while a much larger proportion are thrown away in the taxidermists' shops.

When I shot my first moose the guide, who was something of an epicure, and a skillful cook withal, described stewed muffle in terms of extravagant praise. His mouth fairly watered at thoughts of royal banquets in the woods, when simply a dish of muffle, with pilot bread and tea, had constituted the menu.

"What's it like?" I asked. 
"Why," said he, "it's like-" and he tried to think of something worthy to be compared with it; “it's like-that is-you've eaten-you've eaten pigs' feet? But, thunder! Pigs' feet are no more to be compared to moose muffle-" and he struggled to find words with which to make adequate apology to the moose family for allowing himself to make such an unworthy comparison.

I have eaten of the muffles of many moose since then, and I too am unable to name a familiar dish to which it may be likened. Perhaps turtle soup, in which the fat of the turtle is used in prodigal amount, resembles it more closely than anything else.

Stewed Mufle of Moose.-Clean the muffle thoroughly by skinning, shaving off the skin of the nostrils with a sharp knife. Wash thoroughly and cut into two-inch pieces. Put the meat into a stew-pan, with a slice of clear fat salt pork cut into dice, and an onion cut up fine. Add cold water to cover, and let it stew gently till tender-four or five hours. Add water as it boils away, being sure to have plenty of broth when done. Add sliced potato in season to cook. Thicken, season, and serve.

Newton Hibbs, writing of moose hunting in the 



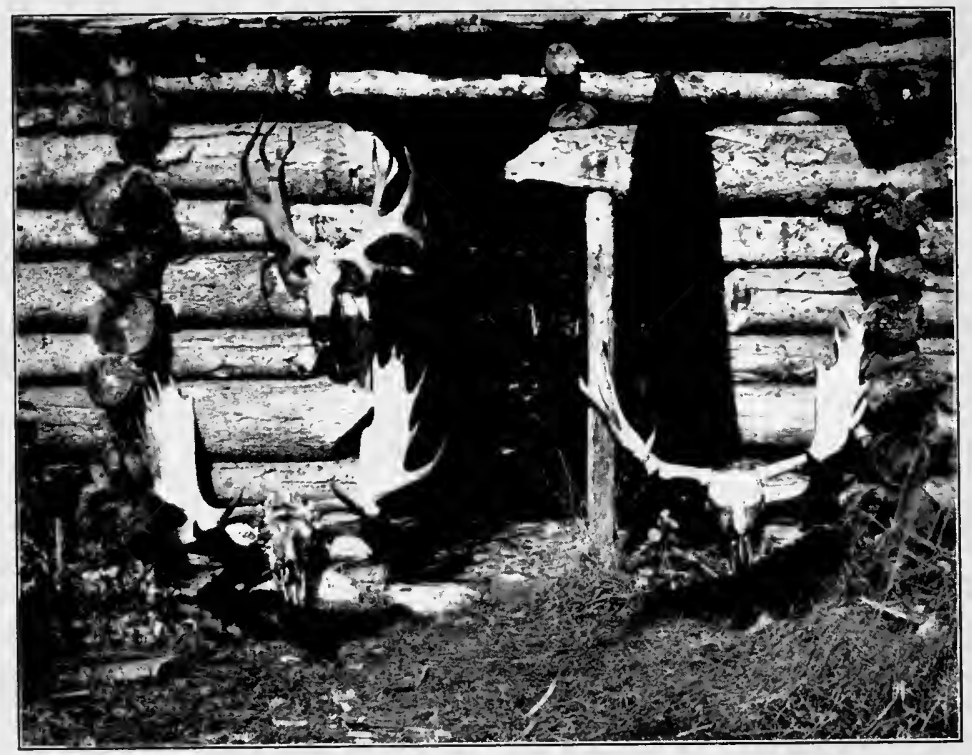

Trophies Brought to Camp 
Rocky Mountains, tells of cooking the muffle of a moose which he killed. ${ }^{7}$

"The head of the moose was cooked in the best style of the hunter's art. It was coated with clay all over, by rubbing the sticky, putty-like substance into the coarse, long hair, till it was enclosed in a case of mud two inches thick. . . . Meantime a hole was shovelled out, large as a pork barrel, and was filled up with dry wood, which was made to burn like a furnace till the sides of the oven were almost white with heat. The head was dropped into the hole, and covered with live coals of fire. Over all was thrown the loose dirt dug from the hole, and the moose-head was left to roast till the next morning. . . . The clay was baked like a brick, and when cracked and torn off it removed the skin, and left the clean, white, sweet meat exposed." Mr. Hibbs vouches for the resulting dish as delicious, and no doubt it was.

A fair substitute for the baking hole dug in the ground is a double baking tin. The muffle should be cleaned as for stewing. If roasted three or four hours in the double baker, with three or four thin slices of pork, the muffle being basted fre-

T The Big Game of North America, edited by George O. Shields (Chicago, 1890), p. 22. 
quently, and water enough being added to make a thick gravy, it should be tender when served. The baking tin should be left uncovered for a while at the last, so the surface of the lip will become crisp. Gravy may be made by adding flour and mushrooms to the juices in the pan, or otherwise, in the discretion of the cook. Roasted in this way the red meat of the cheeks is likely to be tough, but the large, crisp, richly-flavored upper lip will provide a new and agreeable experience for one whose tastes are at all epicurean, especially if he is fond of the "crackling" of roast young pig.

Moose meat is the only kind of venison adapted for preserving in brine. Meat of the other species of deer should be dried rather than corned, if it is not to be used fresh. ${ }^{8}$ In Nova Scotia the farmers who live near the moose country frequently lay down moose meat for winter use. Their brine barrel is somewhat smaller than a flour barrel. The brine is made with about three quarts of salt-more or less according as it is early or late in the fall-and a quarter of a pound of saltpeter to the barrel. Often half a teacupful of molasses is added, and sometimes ground cloves

${ }^{8}$ See p. 18. 
and other spices. Fat and lean alike are laid down. The author can vouch for the excellent quality of moose meat cured in this way. Few would be able to distinguish it from the best corned beef. 


\section{CHAPTER X}

THE FUTURE OF THE MOOSE

IN view of the constantly increasing cost of lumber, our children must consider more seriously than our fathers did the conservation of the timber supply. Vast forests reached from ocean to ocean before the first white settlers came. The portions of this land adapted for raising grain and vegetables will never revert to timber, but much of this ancient wooded area is adapted for nothing but forest, and with intelligent care and protection it may to the end of time supply the lumber markets and the pulp mills of the United States and Canada.

The people of central Spain in the Middle Ages destroyed their forests because the forests harbored the birds which ate their grain. Today it is said if a bird would fly across the arid wastes of Don Quixote's country he must carry his forage with him. The Quixotic Spaniards are rid of the birds, and of the grain as well.

Protection of existing forests is vastly easier than 220 
reforestation: protection of an existing game supply is vastly easier than restocking territory from which game has disappeared. Future generations may see the Western plains restocked with bison, but in our day instead of the bison we have only the reminiscences of old men who tell how they saw the diminishing herds slaughtered for their hides and tongues. This problem of the North American forests is not yet acute, it is true, but the first half of the twentieth century should consider the needs of the second half with respect to lumber; and the twentieth century should not forget the probable needs of the twenty-first century with respect to meat.

The Chief Game Commissioner of Nova Scotia, in an appendix to the report of the commissioners for I913, says: "As far as our Province is concerned it is probable that there will always be ample wild land to provide food and shelter for more moose than we now have. ... The land best adapted for them is useless for almost anything else." This comment on the moose cover of Nova Scotia is equally applicable to enormous tracts in the northern tier of States, and in the British Provinces, from Nova Scotia to Alaska. ${ }^{\mathrm{I}}$

I "Without its big game Alaska would be virtually uninhabitable."Rev. Dr. Stuck in Ten Thousand Miles with a Dog Sled (N. Y., I914), p. 277 . 
If the timber crop of these wild lands is judiciously harvested, all growing trees measuring less than a certain size being left on the stump, there need be no exhaustion of the timber supply, and at the same time browse and shelter may be furnished for a vast number of moose and deer, besides smaller game animals and game birds.

With the constant increase in the prices which the consumer must pay for lumber and for meat, may arise indeed the necessity for the governments to take all large tracts of wild land from private ownership. Under the direction of forest and game commissioners the governments of the United States and Canada could thus exercise control over the supply and the price of lumber and of venison. Great quantities of venison could be systematically marketed every winter. The supply would not be unlimited, but there would be no occasion to apprehend exhaustion.

If a supply of meat equal in quality to the beef and mutton of the butcher shops could be secured at a less price than domestic meat it would be folly not to take advantage of it. "There are counties in the State of New York, within fifty miles of New York City," writes William T. Hornaday, "that could under adequate management be made to yield annually more pounds of 

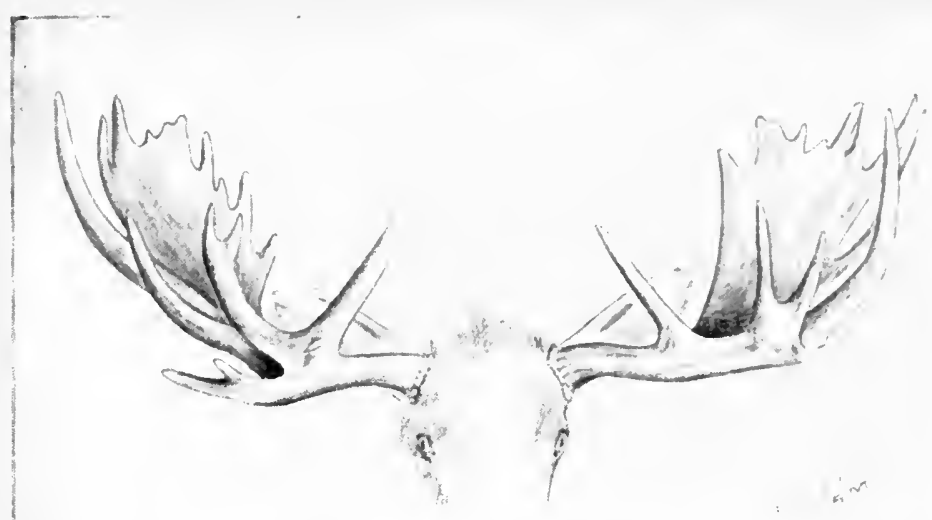

A Nova Scotia Prize'

(See page 360 )

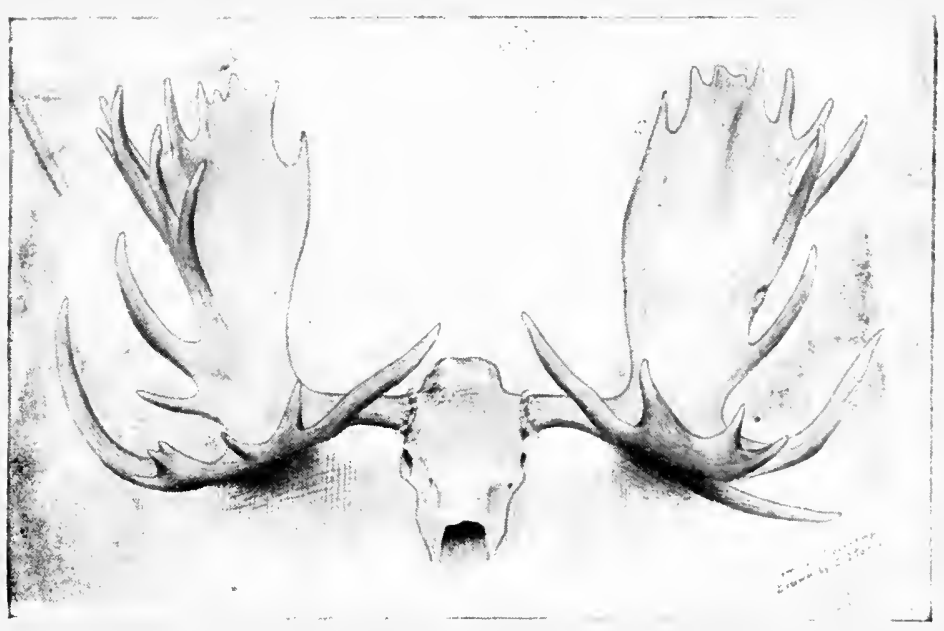

A Remarkable Saskatchewan Head

(See page 358 ) 

venison than of beef or mutton, and this could be accomplished without the annual expenditure by the State of more than five per cent. of the value of the venison." "The unoccupied forest lands of the United States could in my opinion produce annually for our consumption at least 2,000,000 adult deer, without deducting more than $\$ 50,000$ from the wealth of the nation. Those deer would be worth, at a low estimate, an average of $\$$ Io each, which would mean $\$ 20,000,000 .{ }^{\prime 3}$

The wild lands where the moose would thrive and multiply are much more extensive north of the Canadian boundary than in the United States. But on both sides of the international line the potential value of moose and deer as a source of food supply is enormous. At the same time, the value of the healthful recreation which is afforded by the sport of hunting is not to be ignored.

Moose are very hardy, and are never winterkilled. Unlike the wapiti of Wyoming, they require no care or feeding to aid them to survive the rigors of the severest winter. Furthermore,

2 Wild Life Conservation in Theory and Practice (New Haven, 1914), p. IO4.

${ }^{3}$ Hornaday, ubi supra, p. 105. 
they will not destroy the timber. Their favorite food is taken from trees belonging to species which are never marketable. And the moose peels the bark from only one side of a tree: he never girdles a tree as he eats his breakfast. He consumes little of the forage on which the whitetail subsists, and still less of the moss and other things which support the caribou. . The three species of deer live in harmony in the same woodland home, practically ignoring each others' existence. If a given area of mixed woodland and barren is fairly well stocked with a certain number of moose, a large number of caribou may be introduced without the game of either species suffering from lack of food. If then a further addition is made of one Virginia deer for every moose in the tract in question, the effect on the forage supply for the three varieties of deer will be slight-for they eat comparatively few things in common. While this territory is thus harboring and feeding large numbers of game animals there will still be no material impairment in the value of the stand of timber.

In the state forests of East Prussia, and to a limited extent in the forests of Russia and Scandinavia, underbrush is kept trimmed out, and wood-eating animals, such as the elk or moose, are forced to resort to the plantations of young 
trees and to various agricultural crops for a portion of their subsistence. They are unable to save themselves by migration. It will be centuries, however, before such conditions arise in the moose covers of America in any appreciable degree. Indeed, it may be a question whether the net yield of the forest would not be greater if the game as well as the timber were considered an asset, sufficient browse being left to support certain numbers of game animals. Except when deprived of their natural forage in the woods, the elk (moose) of the Ibenhorst preserve in East Prussia never seek food in the grain and potato fields of the neighborhood. ${ }^{4}$

"Venison was more common than beef on the tables of medieval Europe," writes Prof. David E. Lantz of the Biological Survey of the Department of Agriculture, ${ }^{5}$ and game killed by government employes, in forests under government ownership, is now common in many European markets.

In the future, when the problem of meat supply becomes more pressing on the American continent, the necessity may arise to supplement government

${ }^{4}$ A. E. Brehm, Tierleben, 2 d edition (Leipsic, 1877), vol. iii., p. Io9.

5 Bulletin No. 36, "Raising Deer and Other Large Game Animals in the United States" (Dec. 31, 1910), p. I4. 
protection of moose and other deer by government propagation of big game in great national forests. The supply of venison thus secured, and marketed by the government, would be of value for its own sake, and for its influence on meat prices in general. Meanwhile, the pecuniary value of the moose in America is represented in general terms by the money spent by sportsmen who engage in hunting them. As a source of food supply in the centers of population the moose is now a negligible quantity.

With a continuance of the present measure of legal protection, the moose should be found in practically as great numbers centuries hence in America as today, and through the intervening period he can still furnish the best of sport for the hunter. $\mathrm{He}$ is adapted to escape extinction by the same qualities which have enabled him to survive the mastodon, and his other contemporaries of prehistoric times.

The moose is now in possession of a greater area of forest country than any other species of the deer family on this continent. He is the hardiest and most capable of self-protection of all the deer, and this will be about the last branch of the deer family to become extinct in America. ${ }^{6}$ With the extermination of the wolf and the cougar,

${ }^{6}$ Andrew J. Stone, in The Deer Family, p. $29 \mathrm{I}$. 
and with protective legislation, Indian as well as white man being required to respect the law, the causes which were reducing the numbers of the moose on both sides of the continent have been arrested. Given reasonable protection from indiscriminate slaughter, moose will live and thrive as close to civilization as any of the deer family. They are the least gregarious of all the deer, and their natural range affords good cover-two facts which will aid them in avoiding extermination.

Protective Legislation. -Many now living remember when it was common for men to go into the woods of Maine and eastern Canada on snowshoes, when the snow was too deep for the moose to escape by flight, and kill every such animal encountered, without legal restriction, the meat being sold to the lumbermen in their camps, or sledded out for sale at a low price in the towns and cities. No part of the moose's vast range, in either hemisphere, is so remote that such slaughter should again be permitted.

The first measure of protection in any territory

7 All phases of the subject of game protection, from the legal standpoint, are discussed in Case and Comment (Rochester, N. Y.) for October, I9II. This number of the magazine contains articles on "A History of Game Legislation in the United States," "The Rights of Amateur Sportsmen," and "Lxcusable Violations of the Game Laws." Many decisions of the courts of various States are cited. 
should be a bag limit; the second should be laws protecting females and calves. Extending the protection to spike-horns would tend to obviate the risk of cows being shot by mistake, and would deprive sportsmen of no trophies of great interest or value. The hunting season should be limited by law, protecting moose through the season of deep snows, and through the summer, when they are compelled to take refuge in the water. If further protection is needed, hunting in the rutting season should be forbidden. If it is desired to discourage market hunting, in the interest of sportsmen, the sale of game, except on payment of a substantial license fee, may be forbidden. In some places the sale of all game is prohibited, as well as its export.

By the aid of protective measures such as these, the numbers of moose have greatly increased in many portions of the moose's range, and the animals have spread into unoccupied territory, from which they had perhaps been driven by their natural enemies, now exterminated.

An illustration of the value of protective legislation, followed by enforcement of the law, is afforded by the reports of the Game Commissioners of Nova Scotia for I9I3 and I9I4. In these reports figures are given showing the kill of moose in the Province 
in 1908, which was the last year when Nova Scotia law permitted the killing of cow moose, and in each succeeding year. These figures may be tabulated as follows:

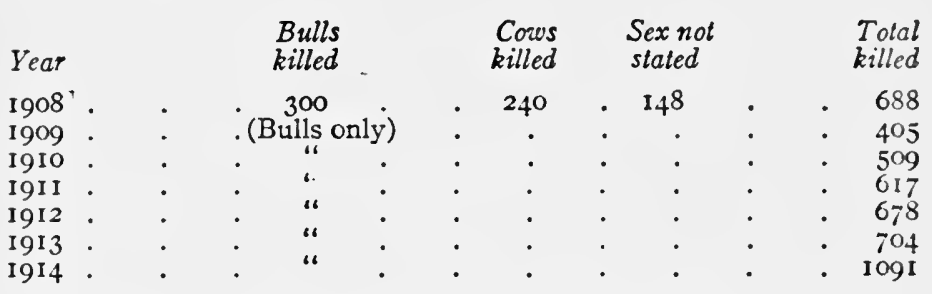

This legislation protecting the females resulted at the end of five years in an increased kill of moose. At the end of two years, in fact, there was an increase in the number of bulls killed, and bulls alone furnish the trophies which are most prized by a majority of sportsmen.

At the close of the hunting season of 1902 the writer had authentic information of twenty-two moose killed that season on the head-waters of the Aroostook River in Maine. He had equally trustworthy information that no part of the meat of any of those twenty-two moose was taken out of the woods,-except the two hundred pounds or more which furnished steaks and stews for the tables of himself and his friends from time to time through the succeeding winter. Very little of the meat of any of the moose killed was consumed in camp. 
At that time a law in Nova Scotia provided that " any person or party of huntsmen who kill a moose or caribou shall carry the flesh thereof out of the woods within ten days after killing the animal." For violation of this law a fine of from fifty to two hundred dollars was imposed. ${ }^{8}$ Under the game ordinance of Yukon Territory also a fine not exceeding five hundred dollars may be imposed on any person who, having killed a moose or other game animal, fails to use the meat for food, or to cause it to be used for food, or to be offered for sale in some market within the Territory. A law of this tenor in most moose-hunting countries would tend to protect game in the less accessible places, leaving the territory where the problem of transportation would be most difficult as a sort of refuge, where the animals could live and breed in comparative safety. This remote territory would of course serve as a source of supply, from which the animals would spread into the country more easily reached by tote team or canoe.

A modification of the Nova Scotia law might be desirable, under which the amount of meat which the hunter should be required to carry from the woods should be limited to fifty per cent. of the

${ }^{8}$ Revised Statutes of Nova Scotia, I900, chap. Ior, sec. 3. The ten days' limitation seems unnecessarily short when game is killed in November, but it has since been reduced to seven days. 
dressed weight, exclusive of head and hide; and in some territories exempting from the application of the law hunters who use the flesh of the animals which they kill as food while in the woods.

Men who hunt include those who care for nothing but a trophy, and also those who care for nothing but meat for the market. But in addition to the head hunters and the market hunters are the sportsmen who enjoy the sport of hunting, who prize the trophies which they secure, and who recognize the economic value of the moose as food. They have no desire to commercialize sport by selling moose meat to the butcher shops; neither do they wish to see moose exterminated for their heads, as the bison were well-nigh exterminated for their hides forty years ago. If the law should compel sportsmen to take moose meat from the woods, and at the same time should close the markets to traffic in game, there would be no just ground for complaint. The sportsman, on reaching the nearest settlement, can always give the meat away, if he does not care to keep it for the benefit of himself and his friends by the aid of some coldstorage warehouse at his home. 


\section{CHAPTER XI}

THE NAMES OF THE MOOSE

A PARTY of sportsmen and guides reached an old logging camp at the close of a short autumn day, and set about the simple task of making the place habitable for a season of moose hunting.

Most of the log structures which had formed the wood-choppers' little settlement had fallen into decay, but one of the smaller cabins had been kept in condition for the use of occasional parties of hunters. With roof and windows in repair, and walls freshly chinked with moss, this cabin was as habitable as ever. The guides, trained from childhood in the use of the ax, soon had an ample store of fuel for the night, and were gathering boughs to cover the withered remains of the beds used by the previous occupants. The old cookstove-and who ever saw a new cook-stove in a logging camp?-was quickly glowing with heat, and fitfully gleaming with light through the broken castings, held together in places by rusty hay wire. 


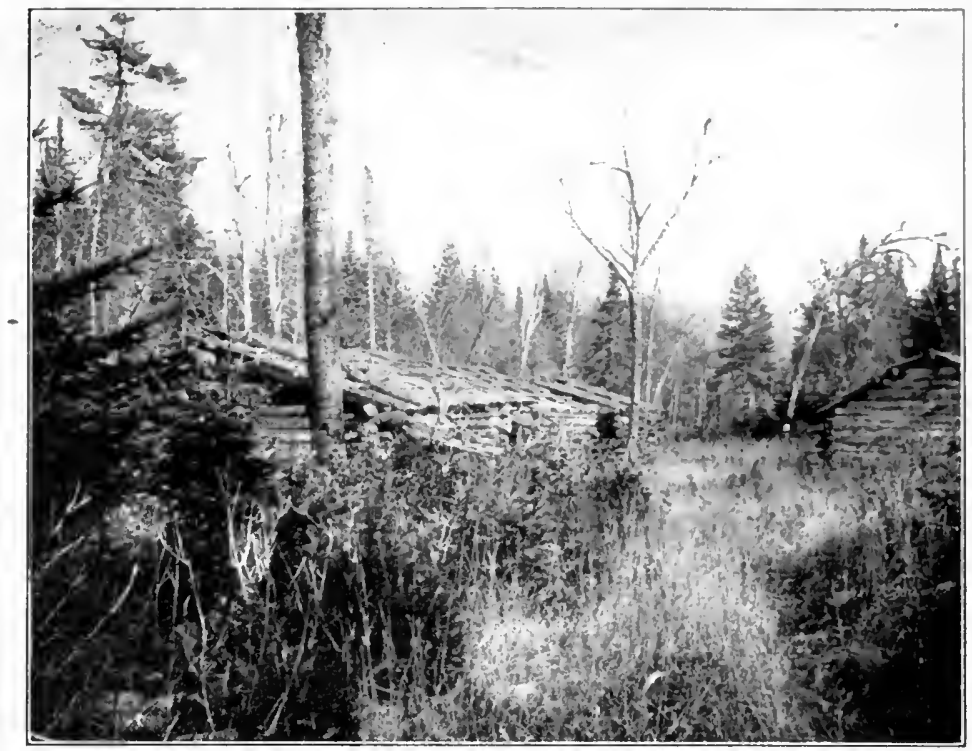

An Old Logging Camp

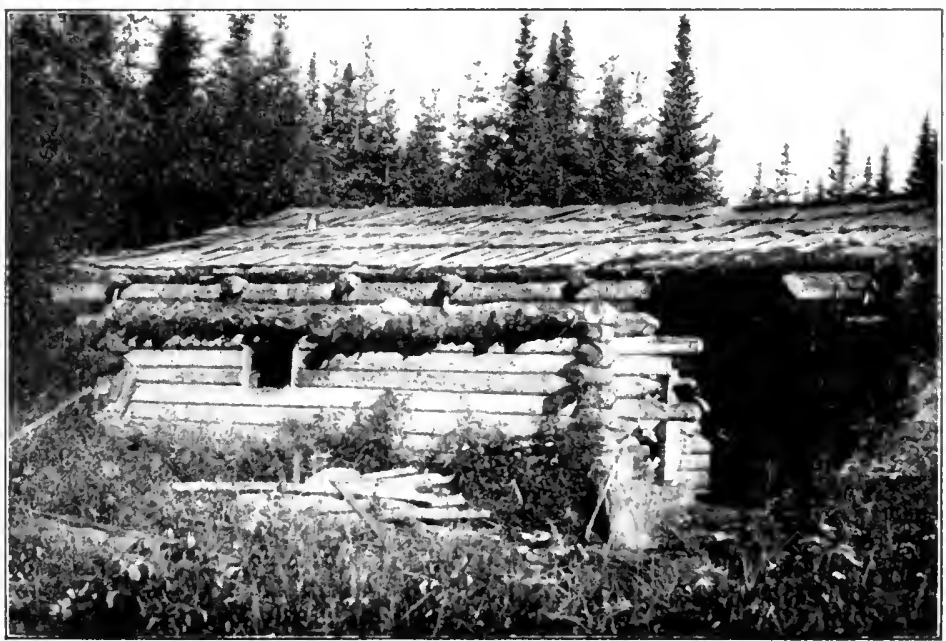

A Logging Camp in the New Brunswick Woods 

To one of the guides was assigned the position of cook, and supper was soon in preparation. Meanwhile the tired sportsmen unpacked their dunnage and made ready for a brief residence in the moose country.

A lamp with a dingy chimney, hanging from a roof timber, cast uncertain rays over the cedar splits which covered the roof, and over the rough logs of the walls. It disclosed a number of bunks across one end of the cabin; it showed pegs and nails to serve the purposes of wardrobe hooks and gun-racks; it showed the stray antler of a moose, blanched and gnawed, and fastened to a log on the side of the cabin, accommodating a store of wellthumbed magazines, while underneath the lamp a trap door in the floor, near the stove, covered a cavity where the occasional sweepings could be consigned to obscurity. For decoration the camp boasted two or three calendars of previous years, allowed to survive for the sake of their pictures, and a few cartoons of a recent Presidential campaign, of interest by reason of the moose which was represented in them.

As the hot biscuit and tea, fried pork and potatoes disappeared from the rough table the question of a name for the camp was raised. Various suggestions met counter proposals. "Camp Moos- 
wa" found most favor, and, when supper was over, one sportsman expressed regret that no paint was to be found within less than two or three days' journey.

"We ought to paint the name on a board," said he, "and put it up over the door."

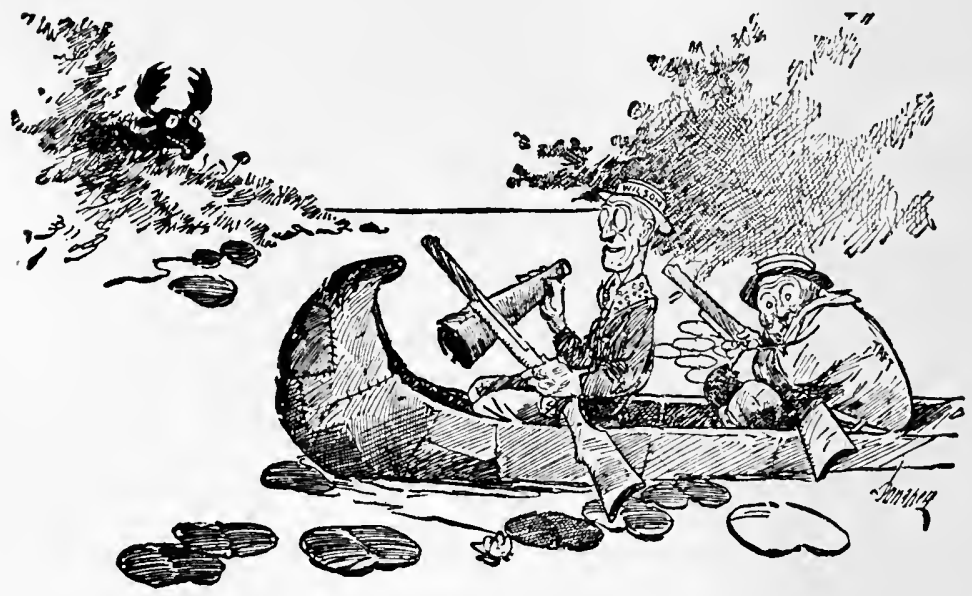

The Moose in Politics

(From the Cleveland Plain Dealer)

"When you haven't any paint there's always a branding iron handy," remarked one of the guides, and he went out in search of material for the desired signboard.

The snow which had filled the air since morning had ceased to fall, the clouds had cleared away, and the guide went out into a world of Christmas trees, heavy with silver floss, and glistening in the 
moonlight. The silvery disc of the orb of night, shining down through the trees, seemed larger and brighter than ever. The stars were gleaming with unaccustomed brilliancy, for nothing can equal the splendor of a night in the northern woods. Everywhere bright lights and dense shadows made the snowy picture seem unreal, and the silence, unbroken silence, added to the impression that it was only a picture, after all.

The guide soon brought into the cabin a small board taken from a condensed-milk box, and with it a number of pieces of iron of various shapes found in the hut which had served the logging crew as a blacksmith shop. He thrust the ends of the irons into the fire, and while the irons were being brought to a red heat the letters were penciled on the improvised signboard. Soon the smoking wood was receiving, letter by letter, the name which should distinguish the camp.

While the amateur sign-writer busied himself with his branding irons, the gathered wisdom of city and forest discussed the origin of the moose's name, and the history of his discovery by the early European explorers. Conflicting views were entertained regarding the origin of the names of the now familiar animals and birds of the North American woods, and from the study suggested 
by this discussion has resulted the gathering of the facts given in this chapter.

The trader, the soldier, the farmer, precede the naturalist in all new territory. They name the places and the things which they see, and when the naturalist arrives he usually finds most of the unfamiliar animals called by wrong names. But it is then too late to correct mistakes.

The earliest explorers in America began, indeed, by misnaming the painted and feathered savages who stood on the shore and stared in wonder at the big boats which had been blown by the wind from an unknown land, and which could carry a whole village at a time. Under the impression that the American coast was really the shore of the Asiatic continent, the discoverers of the New World called the natives "Indians." As a result of this mistake the word "Indian" today may mean anything from a painted Kickapoo to the Maharaja of Mysore or the Gaikwar of Baroda. The word "Amerind" was coined some fifteen years ago in an attempt to correct the error made in the time of Columbus, but such an effort is likely to be as futile as the effort to restore the name "elk" in this country to its rightful possessor.

The early settlers in the English colonies on our 
Atlantic coast-probably in Virginia-met two species of deer. The smaller they called "deer," and by this name the Virginia, or whitetail, deer (Cariacus virginianus) has been popularly known ever since. The other species, the wapiti, was unknown to them, as doubtless the red deer and the elk of Europe were. Seeing the great size of the wapiti, and knowing that the European elk was a large animal, the colonists gave the name "elk" to the wapiti, thus leaving the true elk, alces, without a name. Later, when Englishmen met the true elk in the more northern forests, they gave him the Algonquian name moose.

According to the Handbook of American Indians, issued by the Smithsonian Institution in $1910,{ }^{1}$ the names of the moose in various Algonquian dialects were as follows: Narraganset and Massachuset, moos; Delaware, mos; Passamaquoddy, mus; Abnaki, monz; Chippewa, mons; Cree, monswa. The Montagnais of Quebec, another Algonquin tribe, called him moosh. "All these words signify 'he strips or eats off,' in reference to the animal's habit of eating the young bark and twigs of trees."

* Part I., p. 940.

2 The differences in spelling in the various dialects are partially explainable perhaps by the fact that the Indians employed a sound which cannot be closely indicated by letters of the English alphabet. Sébas- 
Some of the French explorers in Canada found there fishermen who had come from the Basque country of southern France. Meeting the animal now known as the moose, and never having seen the European elk, these fishermen called the moose by the Basque word for deer-orenac. From this is derived orignac, orignal, words used by French writers to designate "l'élan d'Amérique."3 A well-known American writer on natural history makes orignal an equivalent of original, signifying "un type," or an animal of a newlyfound species. But derivations cannot be established by guesswork. The Basques, untrained in zoölogy, in calling the moose orenac, or "deer," were doing as well as they could under the circumstances. The name at least distinguished the moose from the other species of the deer family which were met by the explorers.

Liberties are taken with the names of others of the deer tribe. The Chief Game Guardian of

tien Rasle, the French missionary who compiled a dictionary of the Abnaki language late in the seventeenth century, interprets "orignal" by the word $m \diamond s$. Fr. Rasle employed a character something like the figure 8 to denote this vowel sound. He calls this a guttural ou (oo), "sounded wholly from the throat, without any motion of the lips," and adds that in the case of this $o u$ he was unable to imitate closely the Indian pronunciation.-See Memoirs of the American Academy of Arts and Sciences, New Series (Cambridge, 1833), vol. i., pp. 495, 567, 570.

${ }^{3}$ Larousse, Grand Dictionnaire Universel. 
Manitoba, in his report for 1915 , describes the four species of deer found in the Province as "moose deer, elk deer, jumping deer, and cariboo." The animal called "jumping deer" in Manitoba is called "red deer" in the Report of the Game and Fisheries Department of the Province of Ontario issued in 1915. The name "jumping deer" is not likely to be misunderstood by anyone who has seen the whitetail in rapid flight, but a European might easily interpret "red deer" as meaning the wapiti or "elk deer," since the wapiti is a close kinsman of the European red deer (Cervus elaphus).

The European elk, like his brother the American moose, seems fated to be lost in a maze of etymological confusion. Richard Lydekker, the English zoölogist, writes: "By the ancient Greeks. . . . the great stag we now call the elk was regarded as the personification of strength, and was accordingly named alce, from $\alpha^{\prime} \lambda_{\kappa} \eta$, strength. From this comes the Latin alces, the German Elend, the French élan, and the English elk."4 Mr. Lydekker is evidently less of a linguist than he is paleontologist and naturalist.

The Greek word for strength is $\boldsymbol{a}^{\prime} \lambda \kappa \dot{\eta}$, while the

4The Great and Small Game of Europe, Western and Northern Asia and America (London, I9or), p. 42. 
word for elk is $\ddot{\alpha} \lambda_{\kappa} \eta$ (alke), the transposition of the accent being the only difference. The first Greek writer, so far as known, who mentioned the elk, was Pausanias, the geographer. In the course of an argument to show that the tusks of the elephant are horns, and not teeth, Pausanias cites "the elks, those wild animals in Celtic land," and adds, "the male elks have horns on their eyebrows, but the females have none at all." ${ }_{5}$ Now Pausanias lived about two centuries later than Cæsar. ${ }^{6}$ It is to be presumed that the Greek writer adapted his name for the animals which "have horns on their eyebrows" from the Latin of Cæsar, for the "Celtic land" was Roman territory, and the Greeks doubtless received their information about it from Roman sources.

Andrews, the Latin lexicographer, says that alces is derived from the old German elg. He does not credit either word with Greek origin. $E l g$, then, is the parent word, from which are derived alces, ${ }^{7} \ddot{\alpha} \lambda_{\kappa} \eta$, the modern German Elch and the English word elk. It is unfortunate that a name based upon this root has not been adopted in all languages to designate animals of the Alces genus.

5 Description of Greece, translated by J. G. Frazer, book v., chap. xii. 'See infra, p. 274 . 
Various American writers give Eland and Elend as German words meaning elk, and, as Elend in German means misery, they assume that the Germans bestowed this appellation on the elk on account of its awkwardness and homeliness. ${ }^{8}$ According to Meyers's Grosses Konversations-Lexikon, the German names for the elk are Elch and Elen, and Elen, according to Meyers, is derived from the Lithuanian word elnis, meaning stag. Larousse also, the French lexicographer, derives élan, the French word for elk, from the Lithuanian. Elend was a former spelling for Elen in German, but is now practically obsolete. There is no reason to believe that the moose is as unhappy as his ungainly movements and unattractive facial characteristics might be thought to indicate, and it is pleasing to be able to refute the slander implied by the assumption that he is known anywhere by a name denoting misery.

In various texts which have survived of Pliny's Naturalis Historia the moose (or elk) is denominated achlis or machlis, as well as alces. From Pliny is taken the scientific name Alces machlis,

${ }^{8}$ Seventh Report, N. Y. Forest, Fish, and Game Commission, p. 225. Even Kapherr (Das Elchwild, p. 56) says the Elend was given this name because of the suffering which he endures from various bodily ailments. 
used by Ogilby and others, especially Englishmen. Gray," however, used the name Alces malchis as meaning "the elk or moose," transposing the $c h$ and the $l$. Perhaps he assumed that malchis or alchis was allied to alces, and that some copyist of Pliny had carelessly transposed the consonants in the middle of the word. But Ainsworth, the Latin lexicographer, tells us that achlis (or machlis) is derived from the Greek $\alpha \lambda i \nu \omega$, "to lie down," to which the a privative was prefixed, achlis thus meaning something which cannot lie down, referring to Cæsar's fable of the elk's jointless legs.

In some languages a name signifying simply "large animal" is used to denote Cervus alcesfollowing the "animal magnum" used by certain medieval writers. Thus granbestia is used in Italian and Spanish, and granbesta in Portuguese. Albertus Magnus, philosopher and alchemist, who lived in the thirteenth century, seems to have coined the word equicervus, "horse-deer," as a sort of descriptive name for the elk of Germany, and Latin writers 300 years later used onager or "wild ass" as an equivalent for alces, taking notice of the animal's large ears. In modern times also scientific writers have exercised their ingenuity in devising new names, thus adding to the general confusion.

- Proceedings of the Zoölogical Society of London, I850, p. 224. 
Agassiz called the moose Cerous lobatus, and others have used the names Alces palmatus, Alces muswa, Alce alces, and so on through a very imposing list.

Accepting Judge Caton's dictum that the European elk and the American moose are indistinguishable, ${ }^{10}$ we are led to the following equation:

Europe

Elk (England)

Elch (Germany)

Elg (Sweden, Norway)

Elen (Germany)

Élan (France)

Eland (Holland)
America

\}$=$ Alces $=\left\{\begin{array}{l}\text { Moose (U. S., Canada) } \\ \text { Moose-deer (U. S., Canada) } \\ \text { Flat-horned elk (Rocky Mts.) } \\ \text { Orignal (Canada) } \\ \text { Orignac " } \\ \text { Orignat “ }\end{array}\right.$

There is an increasing tendency among European writers to recognize and use the word "moose" as an equivalent of elk. Since Americans cannot, at this late day, correct the error of their forefathers, and say "elk" when they mean Cervus alces, and "wapiti" when they mean Cervus canadensis, possibly the name "elk" in Europe will ultimately give way to the name used by the North American Indians when they spoke of the great wood-eating deer.

To the list of misnomers must be added the name of the so-called Irish elk. He was not an elk at all, but an animal more nearly allied to the fallow deer. He is known to scientists as Cervus ${ }^{20}$ A Summer in Norway (Chicago, 1875), p. 327. See supra, p. 57. 
giganteus or Megaceros hibernicus. Many skeletons of this animal have been found in the peat bogs of Ireland. Rowland Ward, in his Records of Big Game, describes twenty heads of the Irish elk. One belonging to the Duke of St. Albans measures twelve feet and six inches from tip to tip. A head in the Dublin Museum spreads eleven feet and five inches; it has a palm seventeen inches in breadth, and has eleven points on each side. But these animals were notable chiefly for their antlers: the skeletons indicate a smaller body than that of the moose. "The moose is the largest animal of the deer family, living or extinct. Even the Irish elk ... was a smaller animal." ${ }^{\text {II }}$ A skeleton of the Irish elk in the American Museum of Natural History in New York is six feet high at the withers, and the spread is nearly ten feet.

A restoration of the Irish elk, pictured in Osborn's Age of Mammals, shows an animal with head and body of the wapiti, or red deer, type, rather than of the moose. The characteristic muzzle of the moose, with great prehensile lip, and his short body and long legs are lacking. ${ }^{\mathrm{I2}}$

I Hornaday, American Natural History (N. Y., I9I4), vol. ii., p. I08.

r The Age of Mammals in Europe, Asia, and North America, p. 400. Fossil remains of the Irish elk are found in the British Isles, and in France, Germany, Austria, northern Italy, and even Siberia. (Ibid., p. 4I9.) 


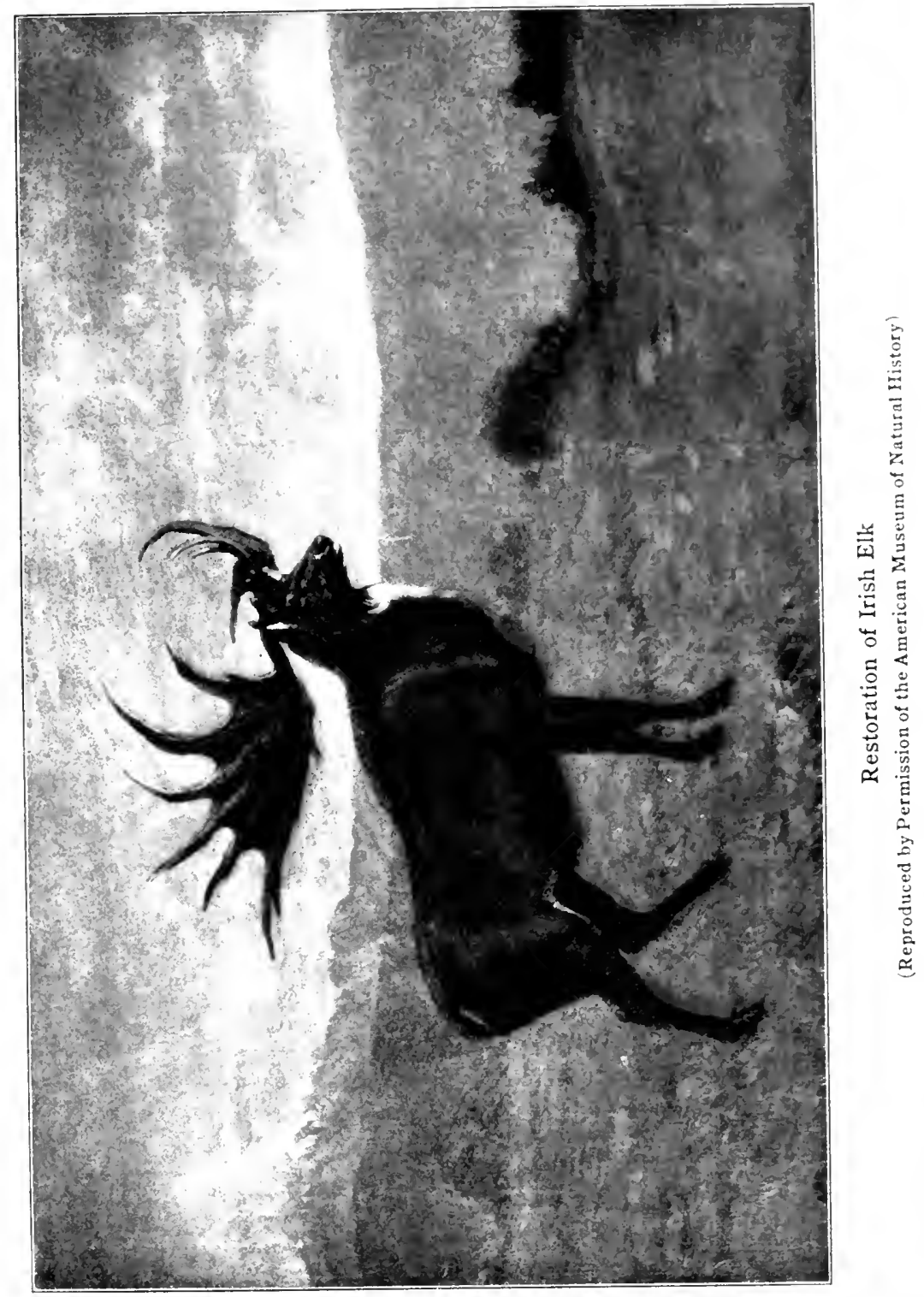





\section{CHAPTER XII}

\section{THE MOOSE IN INDIAN MYTH}

The moose and the Indian have always been closely associated. The Indian gave the moose the name by which he is known to us today. The most skillful hunters of the moose have been Indians, and some writers have even asserted that no one but an Indian can master the art of "calling" the moose in the early fall days when the mating instinct asserts itself. Around anything in which a primitive people are interested, if the people possess imagination, legends are sure to grow up; around everything which was a vital part of the Indian's experience, like the moose, the bear, and the beaver, myths were woven, carrying the uncertain threads which connected man with the Spirits, good and evil, which were created by his hopes and his fears.

But an Indian is not easily persuaded to narrate to white men the folk-tales which he has heard his elders tell beside the lodge fires of his people. 
The red man is sensitive to the white man's ridicule. He knows well that his beliefs are not the beliefs of his white brother-and the white brother sometimes indiscreetly laughs when subjects are discussed which have serious import in the mind of the red man. Furthermore, these tales are told from generation to generation with little change in the Indian phraseology, the oft-repeated telling fixing the form of the story almost as in a printed page. The same stories, however, told to a cynical white man, in the white man's language, become bare skeletons divested of the embellishment which the Indian imagination could so richly supply. Such a skeleton of a story is that given by Thoreau, quoting the old chief of the Penobscots whom he visited on one of his trips to the Maine woods many years ago. ${ }^{\mathrm{I}}$

These myths and legends, which constitute the nearest approach to an Indian literature, have been handed down from time immemorial, grandparents telling them to their grandchildren while the active men of the intervening generation were absent on the long expeditions of war or the chase. They have been rescued from oblivion by the zeal of missionaries, travelers, and others, who knew the Indians well and had their confidence,

See p. 249. 
and who reduced the stories for the first time to writing.

The central figure of Abnaki mythology was the demigod Glooskap, the giant guardian of the Indian race. Glooskap created men, and all the animals. "He made them at first very large. Then he said to Moose, the great Moose who was as tall as Ketawkqu's, 'What would you do should you see an Indian coming?"' Ketawkqu's was a giant, taller than the tallest trees. "Moose replied, 'I would tear down the trees on him.' Then Glooskap saw that the Moose was too strong, and made him smaller, so that Indian could kill him." The short body, humped back, and bulging nose of the moose are due to the awful squeeze he received in the hand of Glooskap when the Master reduced him to his present size. Similarly other animals were transformed by the benevolent Glooskap, to protect the Indians from injury.

Glooskap it was who taught the use Of the bow and the spear, and sent the moose Into the Indian hunter's hands; Glooskap who strewed the shining sands

- Charles G. Leland, Algonquin Legends of New England, page 19. This version of the creation is attributed to the Passamaquoddies. With incidental variations most of the myths are common to many tribes of the great Algonquin family. 
Of the tide-swept beach of the stormy bay With amethysts purple and agates gray, And brought to each newly-wedded pair The Great Spirit's benediction fair.

But the white man came, and with ruthless hand Cleared the forests and sowed the land, And drove from their haunts by the sunny shore Micmac and moose, forevermore. ${ }^{3}$

Most of the striking features of the landscapes which were familiar to the Indians were woven into their mythology. At Bar Harbor are to be found the legendary remains of a moose, killed by Glooskap and turned to stone, while across the bay the petrified entrails of the animal are seen lying where the great benefactor of the Indian race threw them to feed his dogs. The same story, with minor variations, is told of other rocks, and other places, in Maine, New Brunswick, and Nova Scotia. Other characters, too, of the morning twilight of Indian tradition figure in the rôle of the mighty hunter.

Kineo ("the largest mass of hornstone known to geologists"), in the aboriginal imagination was a cow moose lying prone in death, victim of the arrow of some supernatural sportsman. ${ }^{4}$

3 By Arthur Wentworth Eaton.

4 Thoreau, The Maine Woods, New Riverside edition, p. 235. 
Thoreau lacked knowledge of the Indian tongue, and he lacked sympathetic interest in the subject as well, so he gathered from his Indian guides little to add to the published folk-lore of the red men. In his Maine Woods Thoreau relates the circumstances of a visit which he paid in 1853 to Neptune, then, at 89 years of age, the head of the Penobscot tribe. The old Indian gave an account of the origin of the moose, as follows: "Moose was whale once. Away down Merrimack way a whale came ashore in a shallow bay. Sea went out and left him, and he came up on land a moose. What made them know he was a whale was that, at first, before he began to run in bushes, he had no bowels inside, but just like jelly fish.",5

Campbell Hardy also quotes Micmacs in Nova Scotia as saying that the moose originally came from the sea. They believed that when too persistently hunted the animals return to the ocean as their natural refuge. ${ }^{6}$ Moose frequently swim long distances. If a moose should be seen by the unreasoning Indians swimming ashore from some distant but unseen island, it would not be strange if the red men should conclude that the mysterious animal was amphibious. And if the creatures

s The Maine Woods, p. 200.

${ }^{6}$ Sporting Adventures in the New World (London, 1855), vol. i., p. I78. 
migrated to avoid persistent pursuit, the belief that they had taken refuge in the depths of the ocean would not seem to the aboriginal mind an illogical conclusion.

In many Indian legends the characters described are given the names of animals or birds, while having the form and traits of men. Often a single attribute of the animal or bird whose name is used will be mixed incongruously with the qualities of men, and with the attributes of supernatural beings. Such a story is that of Manabozho and the Moose, told by Schoolcraft in The Myth of Hiawatha (1856), page 45. The story was related to Schoolcraft by the Ojibwas of Lake Superior in 1822 .

Another of this type is the story of "The Invisible Boy," related by Rev. Silas T. Rand in Legends of the Micmacs. This is a long story of an amiable young man who took his name, Teäm, from his guardian genius, a moose. The young man's leg was broken while he was moose hunting one day, and his sister went in search of him. On finding him, she proceeded, at the brother's direction, to kill him with an ax. At the instant of the young man's death his body was transformed into that of a moose. The sister then, as previously directed, 
dressed the animal, drying and smoking the meat over a fire. The next day a malicious giant visited her wigwam, and in two meals ate the entire store of moose meat. By the brother's order, however, the sister had cured the scalp of the moose for a "medicine bag." 7 This served as a charm, through whose agency she was enabled to escape from the giant, and from the other perils of the woods. But arriving in a village, and forgetting her brother's warning, she carelessly allowed the medicine bag to leave her possession. Thereupon the brother came to life in the form of an ogre, and proceeded to institute a miscellaneous massacre, which included the absent-minded sister among its victims. ${ }^{8}$

Teäm, in still another folk-tale of the imaginative Algonquins, is represented as a young Indian who was a very successful hunter.

"Once, when he was off hunting, he began to feel lonely, and he said, 'I wish I had a partner.'

7 An early missionary tells of a medicine bag made from the skin of an entire moose-head, except the ears. This was used by an Indian sorcerer for his personal "medicine" or "manitou."-Jesuit Relations (Cleveland, 1898), vol. xxii., p. 317.

${ }^{8}$ Legends of the Micmacs, 1894, p. ror. This story was related to Dr. Rand by an Indian woman in Prince Edward Island in 1848 . Leland, in the Algonquin Legends of New England, p. 140, tells another legend in which Teäm, the moose, figures, but in this case Team is simply a man, to whom was given the designation "Moose," as a sort of surname. 
When he went back to his wigwam that night, the fire was burning and supper cooked, though he saw no one. When he had eaten, he fell asleep, being very tired, and on waking next morning found all in order and breakfast prepared. This went on for some days. The seventh night, on his return, he saw a woman in the wigwam. She did not speak, but made all comfortable, and when the work was done made her bed on one side opposite his. This lasted all winter. She seldom or never spoke; but when spring came, and it was time for him to return to his village, she said, 'Remember me, always think of me, and do not marry another woman.' When he got home loaded with skins and meat, his father had chosen a wife for him; but he would have nothing to say to her.

"Next fall he went back into the woods, and as he approached his wigwam, he saw smoke coming out of it, and when he entered, there sat the silent woman with a little boy at her side. She told the boy to shake hands with his father. Unlike most children, this child was born large and strong enough to hunt with his father, and be of much help to him, so that they got a double quantity of game, and in the spring the man went back to the village so rich that the chief wanted him for a son-in-law; but still he re- 
membered his partner's words, 'Do not forget me; always think of me,' and held firm. On his return to the woods he found a second son.

"Thus he succeeded in getting more game than ever, but, on going home to his village, he forgot his woodland mate, and, yielding to the solicitations of the chief, married his daughter.

"In the fall he took his wife, his father-in-law, and his own father to the woods with him, where this time they found not only the two boys, but a little girl. The new wife gazed angrily at the mother and children, saying, 'You should have told me you had another wife.' 'I have not,' answered the man. At these words the mother of the children rose up, saying, 'I will leave my children with you; but you must treat them well,' and she vanished.

"The boys and men went hunting every day, and the little girl was left with her stepmother, who beat her and made a drudge of her. She bore it patiently as long as she could, but at last complained to her brothers, and the brothers and sister resolved to run away. When they fled, any one who looked from the hut would only have seen three young moose bounding over the snow.

"When the father came home, he asked for the children. His wife said they had just stepped out; 
but when he went to look for them, he saw the - moose tracks, and knew what had happened. He at once took his snowshoes and tomahawk, and started in pursuit of them. He traveled three days and three nights, always following the tracks. Every night he saw where they had nibbled the bark from the trees and where they had rested in the snow. On the fourth day he came to a clearing where four moose were feeding, and he knew the children had found their mother. He struck his ax into a tree and hung his snowshoes on it, then went to her and pleaded to be allowed to go with them; so she turned him into a moose, and they journeyed away together.

"Meantime, his old father at home missed his son and his grandchildren, and went to look for them. He traveled three days and three nights, as his son had done, following the footprints and the tracks until, toward the fourth night, he saw the tomahawk in the tree, with the snowshoes hanging on it. He saw that now there were the tracks of five moose in the snow instead of three, and knew that he had come too late. These were the parents of all the moose in the world today."'

- In Indian Tents, pp. Ior-105. Miss Abby L. Alger, the author, assisted Charles G. Leland in collecting material for the Algonquin Legends of New England. 
The Menomini Indians of Wisconsin, their history, customs, and myths, are described in an exhaustive paper by Walter J. Hoffman, M.D., in the Fourteenth Annual Report of the Bureau of Ethnology, Smithsonian Institution. ${ }^{\text {Io }}$ The tribe is divided into phratries, or clans. A phratry, now extinct, was known as the Moose phratry, divided into the Moose, Elk, Marten, and Fisher totems.

The Menomini myths relate, among other things, the adventures of Manabush, a demigod, grandson of Nokomis, and a mighty hunter. As in most mythologies, the Indian deities have many human characteristics, just as the men and animals of the remote antiquity of primitive peoples have many quasi-divine attributes. Manabush, by the aid of the Wolf, who was a manido, or spirit, and invisible to others, generally succeeded in his hunting. But his wife found fault alike in success and failure, and so, acting on the Wolf's advice, he deserted her.

Manabush in his travels came to two villages, close together, one of which was inhabited by the Elk people and the other by the Moose people. The Moose people appear to have been fourfooted hoofed creatures of carnivorous tastes who lived in wigwams. Their physical characteristics 10 1892-93. See pp. 42, 161, 182-196, of the Report. 
are not well defined in the myths. It would perhaps be difficult to describe creatures, having hoofs instead of hands, who could play a game with plum stones, and beat their vanquished opponents with sticks.

The chief of the Elk people welcomed Manabush, and gave him his daughter in marriage. The people of the two villages were great gamblers, and the Elks were usually the losers. As the myth relates, each game ended with the victors beating the losers with sticks and clubs, and driving them home to their own village. With the arrival of Manabush a new series of games, and tests of strength and skill, were undertaken. The hero, by his own prowess, and by the secret aid of the Wolf, and by other expedients which would never do in a gentlemen's game, was uniformly successful as a gambler and as an athlete, and the Moose at the close of each contest were clubbed back to their village.

Manabush was finally tempted to exhaust his supply of arrows, and his own strength as well, in killing a large number of moose which craftily filed past his wigwam. The slaughtered moose then restored themselves to life and proceeded to kill the exhausted hunter, and chop him in pieces to devour him. 



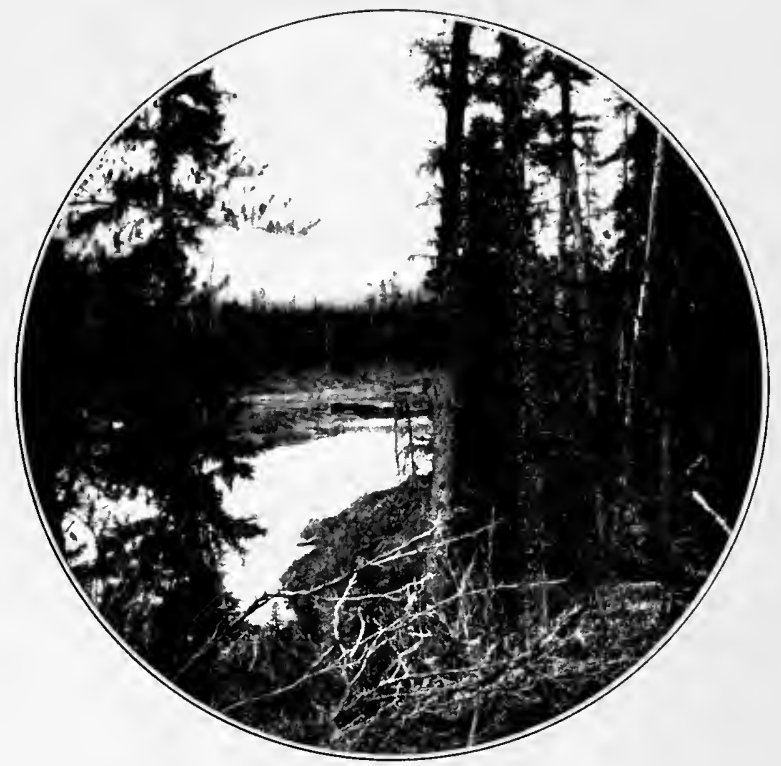

A Vista in the Moose Country

Near North Pole River, New Brunswick

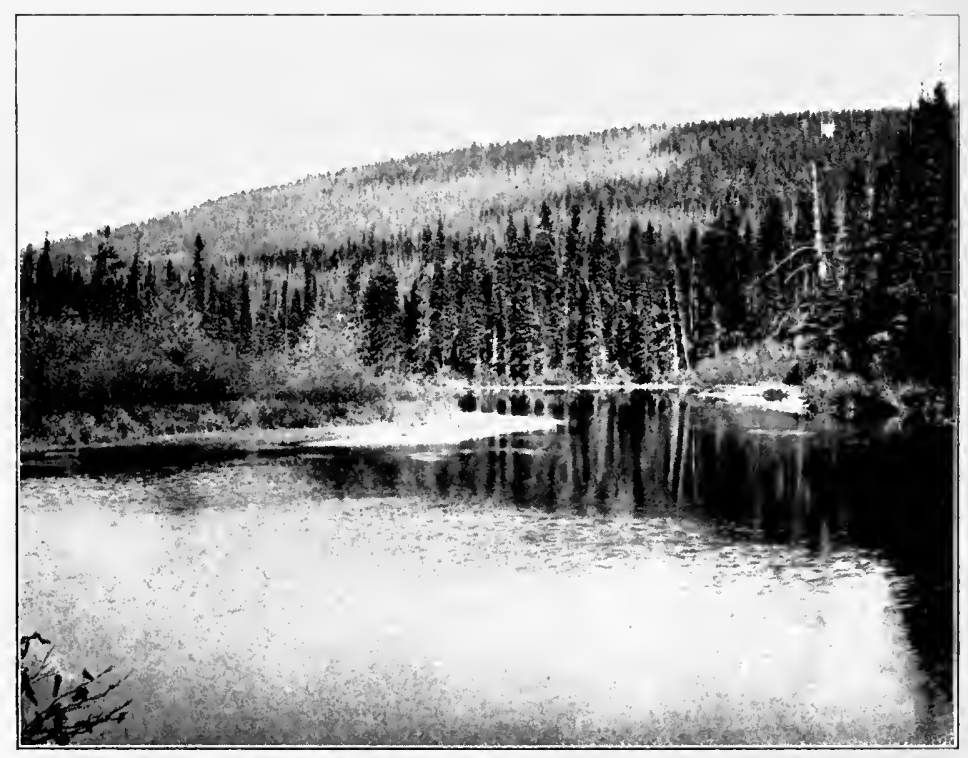

Good Moose Cover 
By aid of the Good Thunder manidos, however, Manabush was assembled in living form again, and with a new supply of willow arrows set out and killed all but two of the Moose people. "These he captured, the hunter saying to them, "Now, you find yourselves in this cedar swamp, where you must hereafter live and feed upon the mosimin (willows); this will be your food for all time.' While saying this to the Moose he placed some willow twigs to their mouths to let them know how they tasted and what they thereafter would have to subsist on. Then the hunter returned to his wigwam, and his adopted people were thenceforth left in peace." ${ }^{\mathrm{Ix}}$

In the same paper (page 214) Dr. Hoffman relates the myth of the Catfish, and their attempt to kill a moose. But the moose trampled to death all the fish which did not seek safety in flight. "The catfish still carry spears, but their heads have never recovered from the flattening they received when they were trampled by the moose into the mud."

A myth of the Dog-Rib Indians relates how Hottah, "the two-year-old moose, cleverest of all the northern animals," aided in the creation of

I Page 196. The story of the Elk people and the Moose people, with some variations, is told in Algonquin Indian Tales, by Egerton $\mathrm{R}$. Young, p. 245. 
the Rocky Mountains. ${ }^{\mathrm{x}}$ The Dog-Ribs live in the timber country between Great Bear and Great Slave Lakes, less than three hundred miles south of the Arctic Circle.

According to this legend, Naba-Cha, "the Big Man," lived west of the Mackenzie River in a wigwam made of three hundred great caribou skins. Each day he consumed a whole moose, or two caribou, or fifty partridges, for he was one of the largest men who ever lived. Now Naba-Cha was cruel and quarrelsome. When he was not on warlike forays into distant parts, he was playing the tyrant over those of his own household establishment. Ithenhiela, "the Caribou-Footed," a young Cree, whom the Big Man had brought back as a slave from one of his marauding expeditions into the South Country, was the especial victim of the bad man's oppression.

Hottah, the moose, finally told Ithenhiela of a country far in the west, through which the mighty Tes-Yukon flowed, a river almost as great as the great Mackenzie. Once beyond the Tes-Yukon the young Cree could find safety under the benign protection of the good Nesnabi, the only man in all the world whom Naba-Cha feared.

2 "The Fireside Stories of the Chippwyans," by James Mackintosh Bell, in Journal of American Folk-Lore, 1903, p. 80. 
Under Hottah's direction Ithenhiela gathered up a stone, a clod of earth, a piece of moss, and a branch of a tree. Then, with Ithenhiela on his back, the moose started across the vast plain which stretched in those days from the Mackenzie to the Yukon. Very soon they saw that NabaCha was in pursuit, mounted on his great caribou. "Fling out the clod of earth!" cried Hottah.

Ithenhiela threw down the clod, and immediately great hills of earth rose up behind them, hills so wide and so high that it was many days before Naba-Cha again came in sight.

When the Big Man seemed again about to overtake them, Ithenhiela threw out the piece of moss. Instantly a great muskeg swamp separated the man on the caribou from the man on the moose. For some days the caribou floundered in the swamp with his wicked rider, while Hottah raced toward the Yukon and safety.

But Naba-Cha again came in sight of his fugitive slave. The stone was then thrown to the ground, and great rocky hills rose up. "Up to the very clouds rose the hills, white with snow, and magnificent, such as had never been seen before." It was a long time before the pursuers crossed the mighty barrier. When they again drew near to the moose and his passenger the branch of the 
tree was thrown down, and a great forest sprang up. The trees were so large and so close together that Naba-Cha had to cut his way through, while the caribou was left behind with his antlers hopelessly caught in the branches.

Again Naba-Cha appeared in sight, but not until Hottah and Ithenhiela were safe on the other side of the Tes-Yukon.

"Help me across the river, Hottah!" cried Naba-Cha. "Help me across, and I will do no harm to Ithenhiela!"

Hottah went back for Naba-Cha, but in midstream, when returning, he threw him off his back, and the bad Big Man was swept into the rapids and was drowned.

The two-year-old moose ("cleverest of all the northern animals") gave Ithenhiela instructions how to find the good Nesnabi, and then returned to his own country.

There was a tradition among the Indians of eastern Canada of a moose of monstrous size which could walk without difficulty through eight feet of snow. "His hide is proof against all manner of weapons, and he has a sort of arm proceeding from his shoulders, which he uses as we do ours. He is always attended by a vast 
number of moose which form his court, and which render him all the services he requires." ${ }_{13}$

In the Jesuit Relation for 1667-68 a missionary told of meeting a band of hunters who said they had found the bed of "the great moose," and had followed the trail a whole day in vain. The hunters, however, said they often killed ordinary moose, belonging to the retinue of the great one, while following the tracks of the invulnerable monster. This supernatural creature had the fifth member, as described by Charlevoix, "dont il se sert comme de main pour se preparer son giste." ${ }^{44}$

Freiherr von Kapherr quotes Prof. Marshall's comment that this myth is evidently the survival of a story of the mammoth and his proboscis, the professor adding that the mammoth probabiy was living in North America later than in the Eastern Hemisphere, and may have lived in the early days of the North American Indians. ${ }^{15}$ Madison Grant ascribes to the Sioux a legend of a moose of the same fabulous size, ${ }^{16}$ but on what authority he does not state.

${ }^{3}$ Charlevoix, Histoire de la Nouvelle France, vol. iii., Journal d'un Voyage dans l'A mérique Septentrionale (Paris, 17+4), p. 127.

14 Jesuit Relations (Cleveland, 1899), vol. li., p. 273.

${ }^{15}$ Kapherr, Das Elchwild (Berlin, 1908), p. $5^{6 .}$

s6 "The Vanishing Mloose," Century .Magazine, Jan., I 894. 
Aside from the myths, properly so called, which cast an interesting side-light on the intellectual development of the Red Men, the Indians entertained many superstitions respecting the moose which entered into their daily life. They believed, for instance, that they could travel three times as far, after a meal of moose meat, as after eating any other sort of food. ${ }^{17}$

In their dreams the moose was a welcome visitor. Charlevoix, the Jesuit emissary of Louis $\mathrm{XV}$., tells us: "The Indians look upon the moose as an animal of good omen, and believe that those who dream of them often may expect a long life." To dream of the bear, on the other hand, was a bad omen, unless the dream should come on the eve of a bear hunt. ${ }^{18}$

Fr. Le Jeune, writing in 1636 , said that the Indians attributed reasoning powers to the moose. They would never give moose meat to the dogs when hunting, for if they did so they believed that the living moose would discover the fact, and conceal themselves. ${ }^{19}$

Various portions of the moose were used as charms and medicinal agents. "The Indian Webbes ${ }^{20}$ make use of the broad Teeth of the Fawns

7 Dudley, Philosophical Transactions of the Royal Society, I 721.

${ }^{8}$ See Jesuit Relations (1637), vol. xii., p. 9 .

9 Jesuit Relations, vol. x., p. 167. 20 Women; literally, "weavers." 
to hang about their Childrens Neck when they are breeding of their Teeth." ${ }_{21}$

The belief that elk (or moose) were subject to epilepsy, and could cure themselves by scratching the ear with the left hind hoof till it drew blood, was current in northern Europe and in America two hundred or three hundred years ago. Human beings who suffered from the same disease were accordingly made to hold the hoof of a moose in the left hand, and rub the ear with it, as a means of cure.

Joseph Jouvency, a priest of the Society of Jesus, wrote a history of the society in Latin, which was printed in Rome in I7Io. In vol. xv., part v., he describes the country and manners of the savages of New France. This is reprinted, with an English translation, in the Jesuit Relations. Describing the moose, which, he says, is called the "great beast" by the natives, Fr. Jouvency tells us:

"The savages eat its flesh, are clothed with its skin, and are cured by the hoof of its left hind foot. In this hoof there is a certain marvelous and manifold virtue, as is affirmed by the testimony of the most famous physicians. It avails especially 2 Josselyn, New Englands Rarities Discovered (London, 1672), p. 20. 
against the epilepsy, whether it be applied to the breast, where the heart is throbbing, or whether it be placed in the bezel of a ring, which is worn upon the finger next to the little finger of the left hand; or, finally, if it be also held in the hollow of the left hand, clenched in the fist. Nor does it have less power in the cure of pleurisy, dizziness, and, if we may believe those familiar with it, six hundred other diseases." ${ }_{22}$

American writers have commented on this superstition as peculiar to the Indians. But some of the most eminent medical men of Europe in the later Middle Ages endorsed the belief, and they employed the hoofs of elk in the treatment of epilepsy long before the first Europeans visited the moose country of the New World. European writers have maintained, however, that this superstition among the North American Indians had an origin entirely independent of European influence. $^{23}$ But the belief is sufficiently peculiar to warrant us in requiring quite positive evidence before we accept this statement of independent origin.

22 "Illius carnibus vescuntur, teguntur pelle, ungula posterioris sinistri pedis sanantur. Huic ungula mira quadam \& multiplex virtus inest, medicorum celeberrimorum testimonio commendata. . . ."-Jesuit Rela. tions (Cleveland, 1896), vol. i., pp. 246-249.

23 See page 350 . 
Fr. Rasle, who began the compilation of his dictionary of the Abnaki language in I69I, gives a word, skass, meaning "le pié gauche de derrière de l'orignal." ${ }_{24}$ He gives no specific words for the other feet of the moose. This then was probably a term well understood in the Abnaki pharmacopœia, and used when the medicine man was treating an epileptic patient. The presence of this word in Fr. Rasle's dictionary, and the accounts of the epilepsy superstition given by early writers on the American Indians, have seemed to confirm the statement that this was an Indian belief, independent in its origin of the belief prevalent in Europe.

But Charlevoix, writing in I72I, says, "On prétend que l'Orignal est sujet à l'Epilepsie," etc. He does not say that it was an Indian belief: his "on prétend" is as likely to refer to white men as to red men. Lahontan in 1686 wrote: "The left hind foot of the female cures the falling sickness,"-but the baron's own skepticism is indicated by the added comment, "si crederefas est." And Lahontan is as likely to have referred to the belief of the Frenchmen of New France as to that of the Indians. Still earlier, in $166_{3}$, Pierre Bou-

${ }^{24}$ See Memoirs of the American Academy of Arts and Sciences, New Series (Cambridge, 18.33), vol. i., p. 495. See footnote supra, p. 237.

2s Nouveaux Voyages, under date of July 8, 1686 . 
cher, writing from Three Rivers, says, "L'on dit que la corne du pied gauche est bonne pour la mal caduc." Here again evidence that this was considered an Indian belief is entirely lacking.

That Charlevoix did not attribute the belief to the Indians is indicated by his statement: "I have heard that the Algonquins, who formerly fed on the flesh of this animal, were very subject to epilepsy, and did not employ this remedy. Perhaps they had better ones." ${ }^{26}$ Inasmuch as Charlevoix does not refer to the remedy as of Abnaki origin, we may conjecture that he looked upon it as one which the Abnaki had learned from the Europeans, and which they used in common with the white men.

It is true some of the writers of that period seemed to consider that this superstition did originate with the Indians. But it may be they were unaware that a similar belief prevailed in Europe. Thus Denys writes: "The moose is subject to epilepsy. The savages say that when he feels it coming on he stops, and with the left

${ }^{26}$ "J'ai oui dire que les Algonquins, qui faisoient autrefois leur nourriture ordinaire de la Chaire de cet Animal, étoient fort sujets à l'Epilepsie, \& n'usoient point de ce reméde. Ils en avoient, peut-être, de meilleurs."(Ubi supra, p. I26.) The Abnaki, among whom Rasle lived, occupied territory east and south of Quebec; the Algonquins lived farther west, on the north side of the St. Lawrence. Charlevoix's journeys took him among the tribes of both groups. 
hind foot scratches himself behind the ear so that the blood flows, and that this cures him." ${ }_{27}$ And Fr. Le Clercq: "The left hind foot cures epilepsy; but it is necessary to secure it, the savages say, at a time when the animal is itself suffering from this malady, of which it cures itself by placing this left foot to its ear." ${ }_{28}$

Fr. Rasle's dictionary shows that the Indians had adopted from their earlier English neighbors the names of certain things previously unknown to them, as cow, pig, cabbage. Probably at the same time they adopted the superstitious belief in the efficacy of moose hoofs in therapeutics, and hence added rkass to their vocabulary, as they added "kass" for cows, "kabits" for cabbage, "pikess" for pigs, and other English words to describe their newlyacquired domestic animals and vegetables.

According to Denys, "in the heart [of the moose] there is a little bone which the Indian women use

${ }_{27}$ Description Géographique, etc. (Paris, I672), vol. ii., p. 320.

${ }^{28}$ Nouvelle Relation de la Gaspesie (Paris, I691), p. 472. Sieur de Dićreville, a French traveler whose Relation du Voyage du Port Royal de l'Acadie was published in Rouen in 1708 , gave this superstition to. his readers in verse:

\section{Il est fort sujet au haut mal,} Mais dans les pieds fourchus de ce grand animal,

La Nature a mis le remede;

Quelle prévoyance! quel soin!

Il se gratte la tête en ce pressant besoin, Et se délivre ainsi du mal qui le possede. 
to aid them in childbirth, reducing it to powder, and swallowing it in water, or in soup made from the animal." 29 Fr. Rasle seems to give an Indian origin to this belief also, for he records an Abnaki word, sskanitéhann, meaning "l'os qui est au milieu du cour de l'orignal." But this superstition was probably an importation from Europe, along with that relating to epilepsy. In the Grand Dictionnaire Universelle of Larousse "os de ccur de cerf" is defined as an ancient medical term, meaning "the bone which is found in the heart of the deer, and which formerly was considered a powerful therapeutic agent." This bone is not an imaginary thing, however, as some writers have assumed. It is known to zoölogists as os cordis. It is a local ossification of the septum between the ventricles of the heart, and is found in a number of varieties of ruminants, including domestic cattle, after they pass a certain age. Its medicinal value is nil.

|' When the settlement of America by Europeans began the Indian medicine man had advanced about as far in his efforts to solve the mysteries of disease as the most learned professor of that day in all the Old-World universities. Neither could justly ridicule the beliefs and practices of the other.

29 Ubi supra, vol. ii., p. $32 \mathrm{I}$. 
Part II

The Old-World Elk 




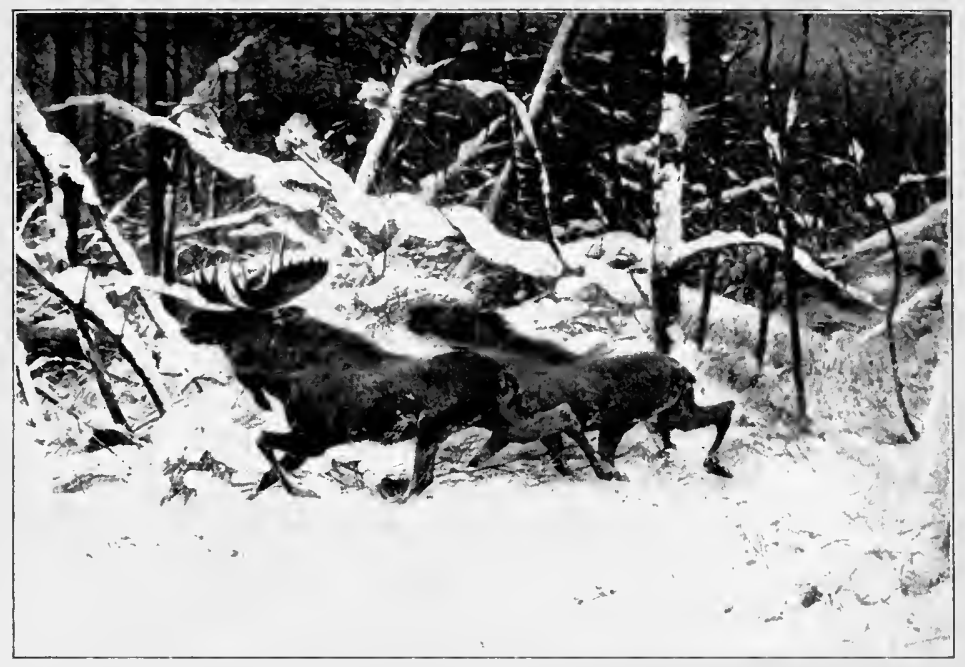

Hunting Russian Elk

From a Painting by Richard Friese

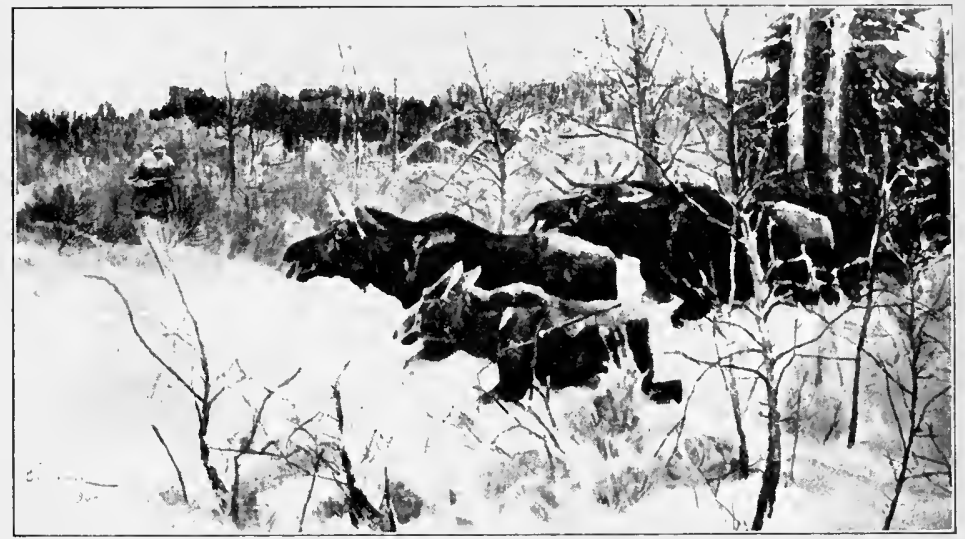

An Elk Drive

From a Painting by K. Wysotzki 


\section{CHAPTER XIII}

\section{THE ELK, ${ }^{I}$ PAST AND PRESENT}

Migrating from the same ancestral homestead - probably in eastern Siberia-thousands of years ago, the elk of Europe journeyed westward, while his brother, the moose, turning toward the rising sun, crossed over to the North American continent. Climatic changes ultimately destroyed the forests of northern Siberia, and the elk moved southward and westward, occupying the broad plains of European Russia, and then advancing into central and western Europe, as far as the Atlantic, and the southern foothills of the Alps and the Pyrenees. Increasing density of population and disappearance of the timber in this western extremity of his ancient range, caused the tide of migration to recede, and the elk, slowly yielding

" "Elk" as here used, and throughout this and the following chapters, denotes Cervus alces, the European and Asiatic relative of the moose. It does not refer to the American elk or wapiti. When the word "moose" is used it will be understood as referring to the American representative of the Alces genus, but without implying difference in species. 
to hostile conditions, withdrew from southwestern Europe into regions farther north and east, which still continue in his possession.

The elk was a contemporary of the mammoth in the eastern hemisphere, as the moose was in the western. Both branches of the great alcine family retain the same uncouth physical characteristics, suggestive of prehistoric times and types, in a remarkably close degree. Fossil remains of elk have been found in many parts of Europe. They show that the type, both in respect to body and antlers, has remained practically constant through thousands of years, and down to the present day. This indicates that the race in all ages has been able by migration to seek the climate and the food which its nature demanded. Thus while climate and the character of vegetation have changed, the elk and the moose themselves have survived practically without change.

Most of the animals which the elk encountered in their wanderings during the earlier ages which followed their advent in Europe, unable to adapt themselves to new conditions by migration, have become extinct, or have survived in a multiplicity of different species greatly changed from the parent stock. The elk and the moose, however, have changed but little since together they cropped 
the tender twigs of the willow in the Asiatic forests. Furthermore, though separated in habitat since long before the first pages of history were written, by the submersion of the neck of land which once connected Asia and America at Bering Strait, the elk and the moose are today so alike in physical

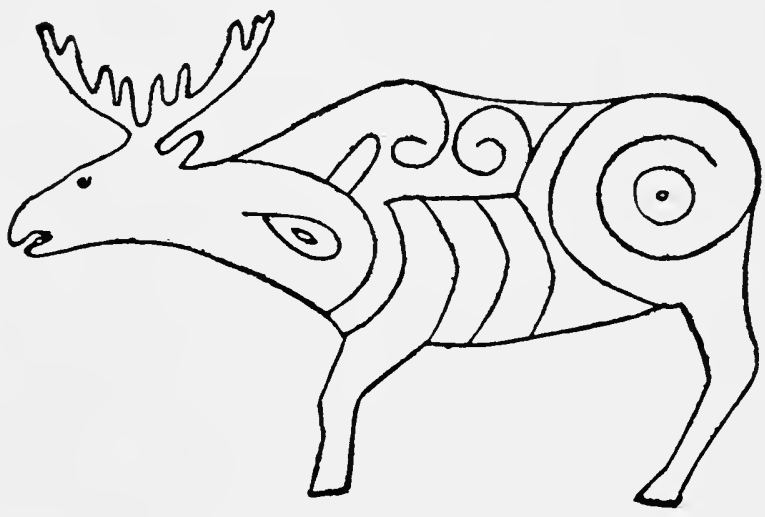

An Asiatic Rock-Carving

characteristics and in habits that many writers refuse to consider them even different species of the same genus.

Perhaps the earliest extant portrait of the elk is one executed by a prehistoric artist in the valley of the Ussuri, on the Russo-Chinese frontier, not far from the Sea of Japan. This region, it is believed, was the elk's ancestral home. The picture is a rock-carving. The animal as the 
ancient draftsman represented him has short legs, it is true, and conventional decoration on his body, but the antlers make the identity of the species unmistakable. ${ }^{2}$

The first appearance of the elk in history is in Cæsar's Gallic War. "There are also animals," writes Cæsar, "which are called alces. . . . They have legs without joints and ligatures; nor do they lie down for the purpose of rest, nor, if they have been thrown down by any accident, can they raise or lift themselves up. Trees serve them as beds. They lean themselves against them, and thus reclining only slightly they take their rest. When the hunters have discovered from the tracks of these animals whither they are accustomed to go, they either undermine all the trees at the roots, or cut into them so far that the upper part of the trees may appear to be left standing. When they have leaned upon them, according to their habit, they knock down by their weight the unsupported trees, and fall down themselves along with them."'3

"See Meyers, Grosses Konversations-Lexikon (Leipsic, 1905), under "Kunst der Naturvolker."

3 "Sunt item qua appellantur alces. . . . Crura sine nodis articulisque habent; neque quietis causa procumbunt, neque, si quo adfictce casu conciderunt, erigere sese ac sublevare possunt. His sunt arbores pro cubilibus; ad eas se adplicant atque ita paulum modo reclinatce quietem capiunt. Quarum ex vestigiis cum est animadversum a venatoribus quo se recipere 
Cæsar wrote B.c. 53, while on his second expedition into the land of the Germani. He was describing the animals found in the great Hercynian forest of southern and central Germany. More than a hundred years later Pliny gave a similar description, but mentioned only the hind legs as jointless, and added: "Its upper lip is extremely large, for which reason it is obliged to go backward when grazing; otherwise, by moving forward, the lip would get doubled up." 4

Gladiatorial spectacles were given in the Colosseum at Rome for nearly four hundred years following its dedication, A.D. So. The dedicatory games continued for nearly one hundred days, and it is said that five thousand wild beasts were slaughtered in the arena during these opening festivities. Julius Capitolinus, in the Historia Augusta, relates that at the close of the reign of the Emperor Gordianus III., in the year 244 of our era, there were exhibited in Rome 32 elephants, Io elk, Io tigers, 60 tame lions, 30 tame leopards, Io hyenas, I hippopotamus, I rhinoceros, Io giraffes, 20 zebras, 40 wild horses, and numberless

consuerint, omnes eo loco aut $a b$ radicibus subruunt aut accidunt arbores, tantum ut summa species earum stantium relinquatur. Huc cum se consuetudine reclinaverunt, infirmas arbores pondere adfigunt atque una ipsce concidunt." - De Bello Gallico, book vi., 'chap. xxvii.

"Naturalis Historia, book viii., chap. xv. 
other animals of various sorts, and that these beasts, with rooo gladiators, took part in the games in the great arena. What part the ten elk played in these gory spectacles Capitolinus does not tell us. Whether they fought with horns or with hoofs, against wild beasts or against equally savage men, we have no means of knowing, but let us hope that they gave a good account of themselves. ${ }^{5}$

In the fifth and sixth centuries of our era elk were rare in France, and they disappeared entirely before the tenth century. They disappeared in South Germany in the ninth century, but presumably were found on the lower Rhine somewhat later, for prohibitions against elk hunting in certain territory there were issued as late as 1025. Elk were found in Switzerland as late as the Middle Ages. ${ }^{6}$

Beneath one of the picturesque houses, five centuries old, for which Nuremberg is famous is a restaurant occupying a quaint vaulted cellar, ${ }^{7}$ and reached from the street by a long and steep flight of stairs. I sat there on one occasion eating my supper, and as I did so I studied a beautiful carved elk head of wood, crowned by natural antlers of moderate size, which graced the opposite

s See also Gibbon's Decline and Fall of the Roman Empire, chap. xii.

"Brockhaus, Konversations-Lexikon, under "Elentier."

7 The Nassauer Keller. 
wall. The presence of such antlers so far from the elk's range excited my curiosity, so I questioned the proprietor.

"Where did those antlers come from?" I asked. "O, right near the city," he replied. "Near Nuremberg?" I asked in surprise. "Certainly," said he.

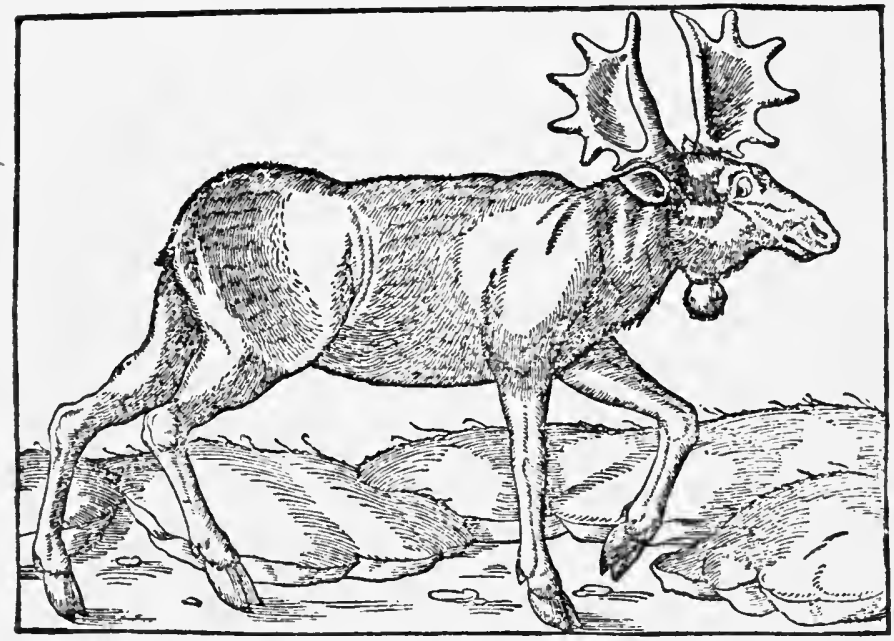

The Elk According to Münster (1554)

"But," I objected, "there are no elk anywhere in Bavaria!"

"O, but this head has been here for several hundred years!" said the proprietor, and I realized again that I was in a land with a much longer history than our America. 
Descriptions of the elk by ancient writers afford as amusing reading as descriptions of the moose by early travelers in America. Sebastian Münster, in his Cosmography, a Latin folio published in

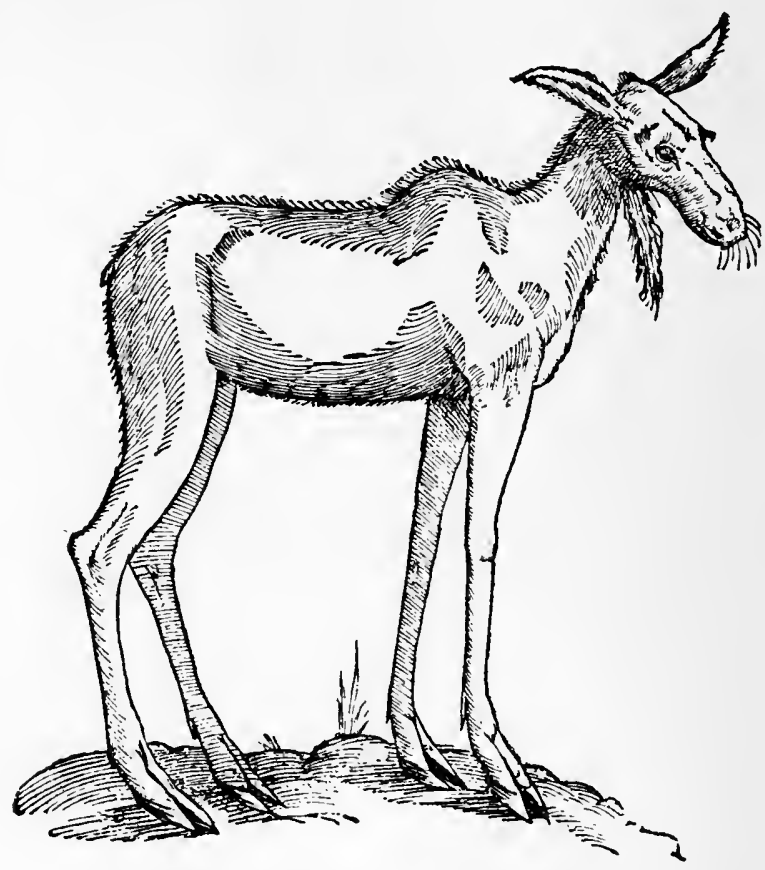

Aldrovandus's Female Elk (I62I)

I554, describes among the animals of Prussia the elk. They are as large as an ass, or a mediumsized horse, he says; their hoofs are used in cases of severe sickness; their skin is so tough that it is not possible to pierce or cut through it; they have 
long and weak legs, are naturally stupid, and a boy can drive them where he will with a switch, but they cannot be made to carry a load on their back. ${ }^{8}$

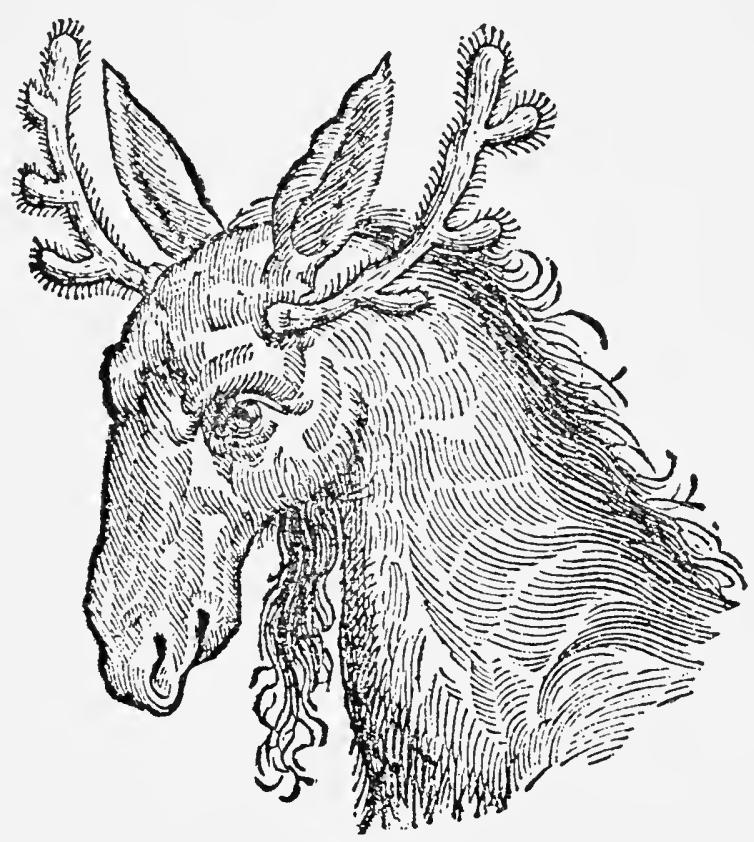

Head of Male Elk (Aldrovandus, 162I)

Aldrovandus, a writer on natural history, and professor in the university at Bologna, treats of the elk at considerable length. He quotes freely from all the writers who had given accounts of the elk, from Cæsar down to his own day, but his

- Cosmographia Universalis-(Basel, 1554), pp. 784-785. 
illustrations were his own. Like other writers of that period he uses the word onager, or "wild ass," as well as alces, to describe the elk. Certainly the female in his picture has a sufficiently asinine appearance to justify the name. ${ }^{9}$ The antlers of his male elk seem to belong to the cactus family.

Long after Münster and Aldrovandus, Rt.Rev. Erich Pontoppidan, "bishop of Bergen in Norway, and member of the Royal Academy of Sciences at Copenhagen," in his Natural History of Norway, describes and pictures the elk. "They are very long-legged," he writes, "insomuch that a man may stand upright under their belly." so This was probably the largest land animal in Norway. The largest creature in Norwegian waters, according to Pontoppidan, was the sea serpent, which he describes on the testimony of credible witnesses as being 600 feet long, and which had been seen to raise its head from the water as high as the main-top of a ship. ${ }^{\text {II }}$ And yet the learned bishop was not of a credulous disposition. He tells us so at considerable length in his preface.

9 Quadrupedum Omnium Bisulcorum Historia (Bonn, I621), p. 870. ro Natural History of Norway, translated from the Danish (London, 1755), part ii., p. IO.

"Part ii., p. 199. 
Elk survived much later in northern Germany than in southern. Johann Sigismund, margrave of Brandenburg, according to official records which are still preserved, killed II,598 game animals between 1612 and 1619 , and of these I I 2 were elk. ${ }^{\mathrm{I}}$ But the numbers of elk in northern Germany were reduced by the encroachments of agriculture, by hunting, and by disease. In Saxony they resisted extinction, however, until I746, in Galicia until I760, and in Silesia until 1776. When finally the cry was raised that they were causing injury to the forests by eating the twigs of saplings, systematic slaughter was undertaken. This resulted about 1830 in the death of the last elk in the province of West Prussia. Since that time the only foothold of the elk in Germany has been in East Prussia, and here, rigidly protected, a comparatively small number still survive. Aside from these the only elk now to be found in Europe are in Russia and in the Scandinavian Peninsula.

We have no reason to suppose that moose in their American home have deteriorated in size since the time of Champlain, and as little to think that the elk today are smaller than those which the royal

$12 \mathrm{~J}$. G. Bujack, in Preussische Provinzial-Blätter, vol. xxi. (Königsberg, 1839), p. 237. 
Brandenburger killed 300 years ago. Dr. Paul Dahms of Dantzic states that the heaviest elk in Johann Sigismund's ample game bag weighed $530 \mathrm{~kg}$. (I 66 pounds) when killed in $16 \mathrm{I} 8$, and that elk as heavy as this are now not uncommon in Europe. ${ }^{\mathrm{I} 3}$

Buffon, the eminent French naturalist, had little chance to study the elk, although friends in America sent him moose antlers, skeletons, and skins. In March, 1784, however, he had an opportunity to study and picture a living elk which was exhibited at the fair of St. Germain, near Paris. This animal was taken, the showman said, fifty leagues beyond Moscow, and was less than three years old at the time when Buffon saw him.

The naturalist had a steel engraving of this elk made to illustrate his Natural History. He explains the strange position of the horns with reference to the head-without, however, being conscious that an explanation was needed-when he says that the picture was made in March, and that the horns had been cast early in the previous January. The honest showman declared that the cast antlers were those of this two-year-old elk, "3"Ehemalige Verbreitung, Aussterben, und Volkskundliche Bezieh. ungen des Elches in Westpreussen," in Globus, a magazine of geography and ethnology, vol. lxxiv., p. 243 (Brunswick, Germany, Oct. 15, 1898). 


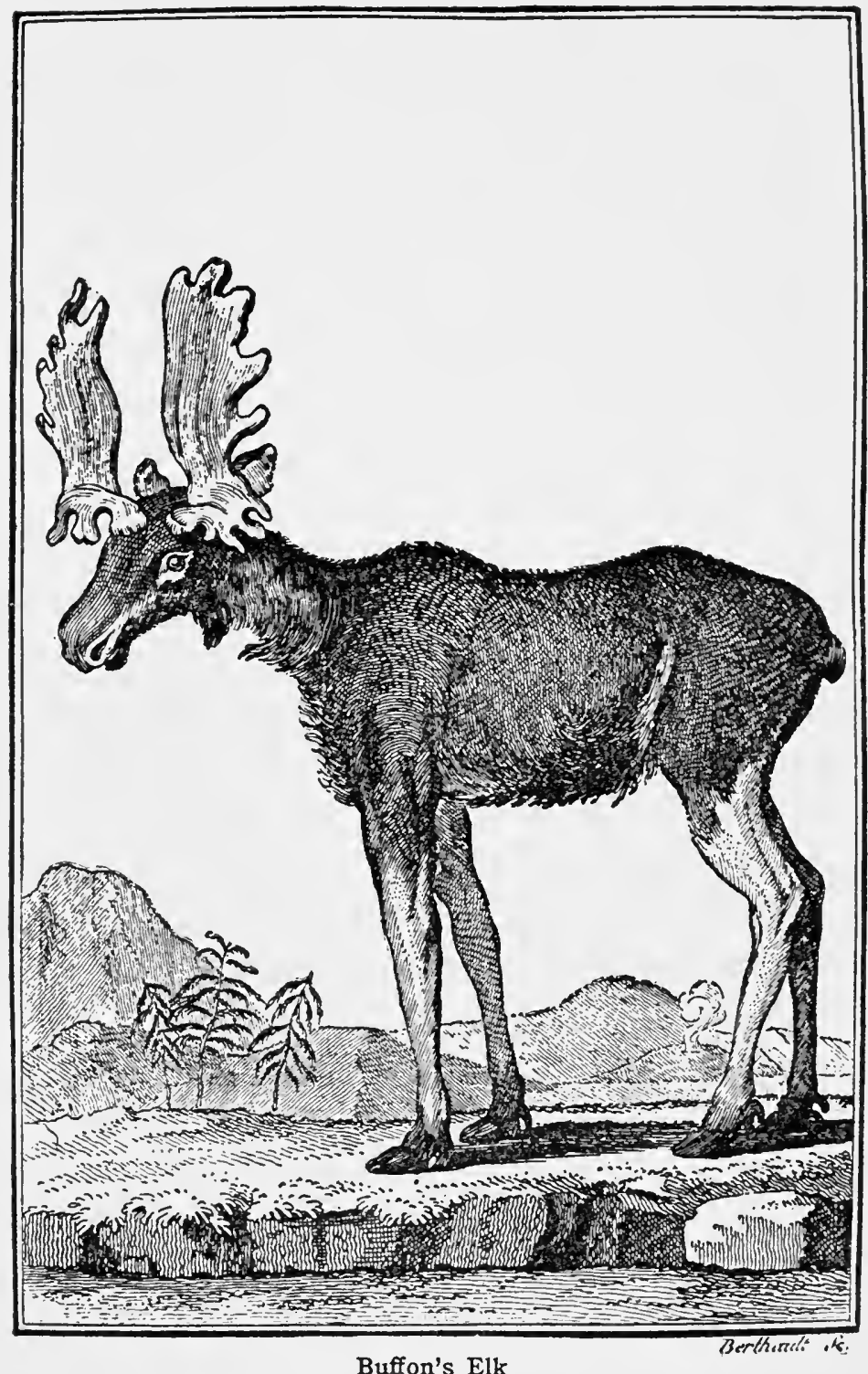


and Buffon caused them to be represented in the engraving. ${ }^{14}$

Prior to the Revolution of 1848 there were from 300 to 400 elk in the forest of Ibenhorst, comprising about twenty-four square miles, in East Prussia. This forest lies near the mouth of the Memel, close to the Russian boundary. During the brief season when all legal restraint was relaxed owing to the Revolution the peasants reveled in their new-found freedom, and in one season reduced the number of elk in the Ibenhorst preserve to sixteen. The price of elk meat at that time fell to five Pfennige a pound ( $\mathrm{I} / 4$ cents). Rigid protection, supplemented by the introduction of Swedish stock in the early '6os, saved the day, however, and in 1874 Ibenhorst and the neighboring minor preserves contained $136 \mathrm{elk}$. The number has since increased to about $1000 .^{15}$

Elk Products in the Arts.-In the Middle Ages elk skin was considered bullet proof-and perhaps two or three thicknesses, properly tanned, would have been impenetrable by the pistol balls of that day. Elk-skin jackets were of ten made for soldiers' wear. They would have the advantage of pliaI Buffon, Histoire Naturelle, Générale et Particulière, edited by Sonnini, (Paris, l'an XI [1802-03]), vol. xxx., pp. '92, 145.

$\therefore 5$ Meyers, Grosses Konversations-Lexikon, supplement for 1910-11. 
bility, which a steel breastplate would not possess. Gustavus Adolphus wore a doublet of elk skin at the battle of Lützen in 1632, and the garment is now displayed in the museum of the artillery arsenal in Vienna. Unfortunately for the Swedish king, however, the leather failed to stop an Imperialist bullet, and the great soldier died in the moment of victory.

Paul I., Czar of Russia, in the closing years of the eighteenth century ordered that his cavalry be equipped with elk-skin breeches, in consequence of which a relentless war was waged on the elk of some portions of the empire. To this fact is ascribed the extermination of the elk in Poland. ${ }^{16}$

The people of the Amur district of eastern Siberia were in ancient times required to pay tribute to the Chinese in elk skins, and Russia more recently required tribute in this material to be paid by subjugated Asiatic peoples. Russia in turn was on some occasions compelled to pay war indemnity to Austria, not in money, but by delivering many hundred wagon-loads of the skins of elk. ${ }^{17}$ In fact, the elk's jacket was his one possession which the European trader formerly

× 6 Dahms, Globus, vol. lxxiv., p. 22 I (Oct. 8, I 898).

17 Prof. Wilhelm Blasius, in Dombrowski's Allgemeine Encyklopëdie der Forst- und Jagdwissenschaften (Vienna, 1888), vol. iii., p. 275. 
especially coveted. Oil-tanned it was highly prized for clothing; slings of elk skin served to hurl stones and other missiles in medieval battles; the skin of the legs, removed without splitting, was used for gun sheaths and pouches for various purposes.

Elk hair was formerly well esteemed by upholsterers, being deemed intermediate between the hair of horses and of cattle in quality. Cushions were filled with it, the covering being of the skin of the same species of animals, and saddles covered with elk skin and padded with elk hair were in common use in an age when the lack of roads adapted for wheeled vehicles raised the saddle into a position of great importance.

Elk antlers were a common decoration for the gables of old-time palaces and hunting lodges, and for the gateways of parks; from the antlers clever artificers fashioned chandeliers and articles of furniture; from them skilled lathe-workers and carvers made the handles of knives and a multiplicity of utensils, and from fragments otherwise unused was produced the glue of the cabinet makers.

The hoofs of elk were in demand in medicine, and if only the hoof of the left hind foot possessed therapeutic value, there were still three other 
hoofs available to be transmuted into combs, cups, bracelets, etc. The bones, too, had their uses. They were very hard and very white, and many times purchasers of ivory wares were indebted to the elk for furnishing the raw material. From the fat of the elk were produced excellent candles. ${ }^{18}$

18 The monographs of both Dahms and Blasius discuss at considerable length the ancient commercial uses of materials derived from the elk. 


\section{CHAPTER XIV}

RANGE OF THE ELK IN EUROPE AND ASIA ${ }^{\text {I }}$

ON the north the elk's range in Asia and Europe is bounded practically by the timber line. The animals are found in a limited area in the easternmost extremity of Siberia, near Bering Strait, but are lacking in Kamchatka, and on the broad tundra farther north. They are abundant in the Lena valley, and are found in the valleys of other rivers which flow into the Arctic Ocean, their range on the Lena and at several other Siberian points extending north of the Arctic Circle.

At the Ural range, where Asiatic and European Russia meet, the northern limit of the elk's range is at about the $63 \mathrm{~d}$ parallel of latitude. Thence westward the line crosses Russia and Finland near the $62 \mathrm{~d}$ and $63 \mathrm{~d}$ parallels. A few elk also are said to be found in southern Lapland, beyond the Arctic Circle. In the Scandinavian Peninsula their northern limit is at about $66^{\circ} 30^{\prime}$.

$\therefore$ See map at page 32. 
In the extreme east the southern boundary of the elk's range begins at the Sea of Japan, in the vicinity of Vladivostok. The line crosses Manchuria, passes near the southern extremity of Lake Baikal, then crosses northern Mongolia, and reaches the Altai mountain range. In general, the mountain ranges which form the water-shed between the streams flowing into the Arctic Ocean and those flowing into the Pacific, mark the southern boundary of the elk's Asiatic range. From the Altai Mountains to the Ural range this southern boundary line trends north of west, crossing into Europe at about the $57^{\text {th }}$ parallel.

The southern boundary of the elk's range crosses European Russia in an irregular line, trending south of west, and reaching, in the government of Volhynia in West Russia, at about the 5Ist parallel, the southernmost point to which it extends in Europe. Some centuries ago the forest areas of Russia extended farther south than they do today. As the forests were destroyed the elk retreated northward, but since 1850 there has been a marked tendency to reoccupy some of this territory once abandoned. Fr. Th. Köppen, a Russian writer, declares that no similar instance is known where any great mammal, having once yielded to the advance of agriculture, has spread 
out and multiplied again in territory which it had deserted. ${ }^{2}$ Elk are found in the German province of East Prussia, in all the Baltic provinces of the Russian Empire, and in Finland. They inhabit also in considerable numbers the extensive mountainous areas of Scandinavia, the southern boundary of their range in Sweden being near the $57^{\text {th }}$ parallel.

Norway, Sweden, and Russia are the hunting grounds for elk in Europe. Few foreigners visit Russia in quest of game, however, while many Englishmen and Germans have been in the habit of leasing hunting privileges in the Scandinavian Peninsula. In the eastern provinces of southern Norway, especially the district of Drontheim, the great forests of deciduous trees, abounding in mountain ash, harbor many elk, and the number is believed to be increasing, thanks to protective legislation. ${ }^{3}$

"It is an undoubted fact," wrote the late Sir Henry Pottinger, "that in the last fifty yearsin Norway, at least-their number has greatly

'Die Verbreitung des Elentiers im Europäischen Russland, published by the Imperial Academy of Sciences, St. Petersburg, 1883. Concerning the limits of the clk's range in European and Asiatic Russia the present writer has accepted in general the statements of Martenson in Der Elch (Riga, 1903), pp. 89-Ior.

${ }^{3}$ Hesketh Prichard in Blackwood's Magazine, July, 1906. 
increased, for in the fifties, as the writer can testify, they were seldom seen or heard of in many districts where they are now not infrequent... In Norway it is forbidden, under a heavy penalty, to kill more than a single elk, bull or cow, on each farm or registered division of land. ... The shooting of calves is strictly forbidden." 4 In I894 Pottinger wrote: "Altogether about 850 elk on the average are killed yearly in Norway, and in Sweden rather more than double the number."5 Increased restrictions in Sweden have reduced the number killed, while in Norway an increase is noted. Martenson, quoting statements furnished by the Norwegian Hunting and Fishing Association, wrote in 1903 that the annual kill in Sweden was 1300 or 1400 elk, against 900 to 1000 in Norway. ${ }^{6}$

Seeking information industriously from all available sources, Martenson estimated the number of elk in all portions of his European and Asiatic range. Scandinavia he credits with from 8000 to Io,ooo elk, and this estimate, in view of the numbers annually killed, would seem to be sufficiently conservative. In Finland he notes a marked

\footnotetext{
4 Encyclopedia of Sport and Games (London, r9rr), vol. ii., p.r77.

5 Big Game Shooting (Badminton Library), vol. ii., p. 125.

' Ubi supra, p. 90.
} 
increase in numbers, due, however, to greatly increased restrictions in hunting privileges-restrictions made necessary by the diminishing numbers of elk thirty or forty years ago. To Livonia, his home province, Martenson credits I600 to I 800 elk. To Esthonia, on the north, he credits 500 or 600 ; to Courland, on the south, 800 or 1000. But the elk of the Baltic provinces are smaller than those of Scandinavia, and much smaller than those of eastern Russia and Siberia.

With a view to estimating the number of elk in European and Asiatic Russia, Martenson studied the reports from the principal fur and hide markets of the empire. "According to returns gathered by N. Turkin and others," he writes, "the number of skins of wild animals taken yearly in Russia amounts to about 50,000,000, of which from 250,000 to 300,000 are elk." If we accept these figures, we will not wonder when Mr. Martenson adds the estimate that the number of elk in the entire Russian Empire is at least 2,000,000. ${ }^{7}$

The city of the czars, newly christened Petrograd, was no doubt once the home of the elk. One of the islands on which the city is built, Wassilij-Ostrow, was formerly known by the Finnish name Hirwi-Saari, or elk island. And 7 Ubisupra, pp. 166-167. 
today hunters living in Petrograd can reach good elk preserves within two or three hours' journey from the capital by rail. In the government of Moscow, too, elk are found in fair numbers, although sixty years ago they were practically unknown in that region.

The number of elk in East Prussia has increased rapidly since the last decade of the last century. By the construction of dikes the frequent floods in the delta of the Memel have been prevented, and the elk have profited by the improved forest conditions which have resulted. In 1906 there were about 720 elk in the province, practically all occupying the small triangle bounded on the northeast and northwest by the Russian frontier and the Baltic Sea respectively, and bounded on the south by the Pregel River. It was found necessary to kill an increasing number yearly in the interest of forest conservation. ${ }^{8}$ Five years later there were said to be about rooo elk in the province. ${ }^{9}$ According to Dr. Fritz Skrowronnek twenty-five or thirty elk are killed yearly in the East Prussian preserves by the Kaiser and other privileged hunters. Dr. Skrowronnek tells of elk drives on

${ }^{8}$ Der Mensch und die Erde (Berlin, I906), vol. i., p. 3 I4.

- Meyers, Grosses Konversations-Lexikon, supplement for I9ro-I I. 
two successive days in 1904 in which "der oberste Jagdherr" killed one small elk each day. His army of beaters numbered 300 men. While stillhunting, on foot and by boat, on the same visit to East Prussia, the Kaiser saw no game. ${ }^{\text {xo }}$

Elk occasionally migrate from Russia into German territory. Skrowronnek tells of such an instance, in 1904, when many Russian elk were driven by a forest fire from their native cover, and took refuge in the woods beside the German Memel. And an English woman, instructor of the Kaiser's daughter, relates how an elk, migrating from Russia, was reported as being seen in the imperial hunting domain of Rominten in East Prussia seven or eight years ago. "The Kaiser ordered out all the automobiles and carriages," she wrote, "and that every available person was to serve as beater, Her Majesty and the Princess and the ladies being specially invited in that capacity. . . .

"The car flew along, the Emperor talking volubly about the Elch and its habits, and his hopes of slaying the confiding creature; and at last we were deposited about eight miles from home on a rather squelchy, marshy piece of ground, where we were met by Baron von Sternburg and commanded to follow him in perfect silence, the Emperor meanso Lustiges Weidwerk (Berlin, 1905), pp. x3, $_{9}$. 
time going on in the car in a different direction. After a long damp walk we were all posted at intervals of about a hundred yards along a thick alley of pines, with whispered instructions to stay where we were and prevent the quarry from breaking through, although we all had grave doubts as to our ability to prevent any animal as large as a moose from doing anything it felt inclined. I went up to the gentleman on my left and whisperingly asked what methods I must employ supposing the mighty beast suddenly appeared in front of me, and he indicated a feeble wagging of the hands as being likely to turn it back in the direction of the Emperor's rifle." ${ }^{\text {Ir }}$

But the "moose" escaped back to Russian territory, close at hand.

In view of the enemies which the elk has had to encounter, and the agricultural improvements which have deprived him of subsistence in many portions of his ancient range, and the lack of legislation, and excess of legislation, which have imperiled his existence, it is remarkable that the elk of Scandinavia should thrive as he does today. Accusing the elk of damaging the crops,

II Memories of the Kaiser's Court, by Anne Topham (N. Y., 1914), pp. $254^{-255}$. 
the ancient law-makers of West Gothland (southern Sweden) classed him with the fox, the wolf, the lynx, and the bear as a noxious animal, and a price was placed on his head. ${ }^{12}$

Outlawed by those who in a later age would have given him legal protection, and preyed upon by the wolf-packs of only seventy or eighty years ago, the numbers were so reduced in Sweden and Norway that it was necessary to wage systematic warfare on the wolves and prohibit killing the elk at any season, save that every tenth year elk might be hunted for a brief period under rigid limitations. There is now a short open season each fall, the shooting season in Norway, according to the latest information at hand, being the last twentyone days in September.

In Russia "there are strict laws protecting hinds [females], enforced by a fine of one hundred roubles for killing each one, but the bulls are mercilessly destroyed without regard to age or size; hence fine palmated horns are growing very scarce in the neighborhood of big towns, where numerous shooting clubs exist. The open season lasts from the end of August till the 3 Ist of December."'

× Lloyd, Scandinavian Adventures, vol. ii., p. 93.

${ }_{3}$ E. Demidoff, Prince San Donato, in Sport in Europe (London, I901), p. 389 . 
The right to hunt in Russia is vested in the land owner, but he is generally required to pay a moderate license fee. In a large portion of the northern and eastern elk territory of European Russia, however, the residents are not required to pay the hunting tax. This exemption was made in consideration of the poverty of many of the people. The privilege of hunting on public lands in these sections was also easily obtained. The beneficiaries of these exemptions and privileges at once concluded that they were subject to no legal restrictions, and a class of idlers became professional hunters, destroying game with ruthless hand. These conditions, in conjunction with improved firearms, and an increasing number of forest fires, caused a marked decrease in the amount of game in many portions of the Russian elk range. ${ }^{14}$ Whether more recent legislation has bettered these conditions the author is unable to say.

Until quite modern times hunting in most parts of Europe was a special prerogative of royalty and the nobility. Even today most of the best territory is in the hands of wealthy individuals who jealously guard their exclusive hunting privileges. These conditions have always produced a large 14 Martenson, pp. 164-165. 
class of poachers, in dealing with whom are found the most serious problems which the owners of game preserves have to meet. The elk, like the timber, constitute a portion of the value of a landed estate, and both portions of the assets are guarded from theft at considerable expense by the maintenance of a large force of men.

The privilege of hunting is often leased in Russia to sportsmen in the cities. In such cases the successful hunter is entitled only to the head and a certain small piece of meat, the rest of the meat, the hide, feet, etc., remaining the property of the owner of the land where the elk was killed. ${ }^{15}$ In Norway also "the sportsman's share of any animal he kills is only the head with the head-skin, with twenty kilos of elk-beef; the remainder of the carcass goes to the owner of the farm on which the elk is first sprung, whether actually killed upon it or over the boundary upon the land of his neighbor." ${ }^{\prime 6}$ There is no bag limit in Norway, but the hunter may not take more than one elk in a herd if several are found together. The non-resident license fee is 100 crowns $(\$ 27) .{ }^{i 7}$

15 Kapherr, Das Elchwild (Berlin, 1908), p. 74.

16 Prichard, ubi supra.

17 Hiorth, Elch- und Schneehuhnjagd in Norwegen (Christiania, I910), pp. 6, 7 . 
RANGE OF ELK IN EUROPE AND ASIA 299

By leasing the hunting privileges of several farms the sportsman may kill a number of elk in a season, and the sport is not necessarily very expensive. 


\section{CHAPTER XV}

TRAITS AND HABITS OF THE ELK

ELK have been subjects of closer observation in many portions of their European range than have the moose in America. The precise knowledge of the elk's traits and habits which might be expected from this fact is nevertheless lacking.

In respect to his size writers are hopelessly out of accord, owing to the lack of an accepted rule for ascertaining dimensions. Of one fact there can be no doubt, however-the elk of average size is smaller than the average moose. Sir Henry Pottinger, who for six years leased preserves in Sweden and Norway and hunted elk with much success, gave the height at the withers of the average full-grown Scandinavian elk as 68 or 69 inches, and the girth as 83 or 84 inches. $^{\mathrm{I}}$ The live weight he was unable to ascertain. Russian writers describe elk weighing, undrawn, from 1075 to 1100 pounds, but these they admit are exceedingly rare.

× Big Game Shooting (London, I894), vol. ii., p. I 30 . 
The age usually attained by the elk is stated by most writers to be from 16 to 20 years. Martenson, however, credits the elk with sometimes attaining an age of from 30 to 36 years. He cites no specific instance where a specimen was known to have reached such an age, but draws his conclusion largely from a formula of zoölogists that among mammals the average attainable age is seven times the period required to attain full growth. Martenson tells of a female elk in the forest of Ibenhorst which was easily identified by reason of the loss of the left eye and by other marks. Yearly from 1854 to 1865 she bore two calves, then was barren for three years, but in 1869 and 1870 bore one calf each year. "She was accordingly at least twenty years old in 1870 , but showed at that time no signs of old age."

Dr. Blasius, while quoting the same formula, gives the length of life of the elk as only from 16 to 20 years. He adds that while the life of the elk is relatively shorter than that of most mammals, this condition is offset by the elk's superiority with respect to producing young. ${ }^{3}$ In the case of most species of deer a single fawn is born each season, but the female elk commonly bears two

2 Martenson, Der Elch (Riga, I903), pp. 15-16.

3 Ubi supra, p. 273. 
calves. Other zoölogists state that the maximum attainable life of most mammals is seven times the time required to reach maturity, not seven times the period spent in attaining full growth. Moose are believed to be capable of reproduction when $2 \mathrm{r} / 2$ years old, though not fully grown, and hence the zoölogist would consider them mature at that age. Under this formula, therefore, their limit of life would be less than 20 years.

The rutting season of the elk is generally somewhat earlier than in the case of the moose. In East Prussia and the Baltic provinces of Russia it begins late in August and continues until the last of September. In Scandinavia and Asiatic Russia, however, it begins about the middle of September and continues until the middle of October. Antlers are shed much earlier too in western Russia. Bulls in their prime drop their antlers in November on the east shore of the Baltic, while in the rest of the elk territory of Europe and Asia they carry them a month or more later.

In the Baltic provinces elk are found in larger herds than is usual with the moose. Often fifteen, or even more, are found together, and in the rutting season they recognize the leadership of a strong bull, especially if he is armed with formidable antlers, and shows a disposition to use them to 
enforce his supremacy. The theory that elk are monogamous has almost no adherents in Europe. Exciting stories are told by Russian writers of fatal encounters between bulls in the rutting season. A single powerful bull will often remain in the company of several cows through the season, and succeed in keeping all rivals at a distance, though not without many bloody contests. The combativeness of cows in protecting their young from apprehended molestation by men is frequently mentioned by Kapherr.

The elk seems to show a greater fondness for low moist ground in the Baltic provinces, and in western Russia generaliy, than in most of his range. The Germans, indeed, sometimes speak of him as the Moorhirsch, or Sumpfhirsch, meaning "marsh stag." If he frequents such territory more than the moose of America do, it is probably because he is less molested there, and better fed, than in the comparatively restricted uplands which are left available for his use. He seems to be even more fond of the water than his American relative. According to Shrowronnek the elk of East Prussia not infrequently swim across the Kurisches Haff, a distance of twenty kilometers (more than twelve miles).

The food of the elk is drawn from the same wide 
variety of trees, shrubs, and water plants as in the case of the moose.

In both European and Asiatic Russia it has been observed that elk make periodic migrationsperhaps in imitation of their neighbors the reindeer. Many of these journeys between the uplands and the lowlands are short, and have no more significance than the movements of moose in America in anticipation of a winter of deep snow. Siberian elk, however, are said to make annual journeys at the end of winter from the forest cover of the southern mountains to the broad open tundra of the north, covering 400 or 500 miles. Persecution by insects and parasites is believed to have as much to do with these movements as questions of forage. ${ }^{4}$

A Russian naturalist, Sabanejeff, made close observations of the annual migrations of great herds of elk from the west side of the Ural range, north of the 6oth parallel, across the mountains in a southeasterly direction through six degrees of latitude. The journey toward the southeast begins in September, in anticipation of the deep snows. In the winter refuge of these elk, southeast of Ekaterinburg, the season of snow is much

4 Martenson, ubi supra, p. 105. 
shorter, and its depth much less. It has been observed that in mild winters the migrating herds are much smaller than in seasons of greater snowfall. On both sides of the mountain range many elk are victims of slaughter during these semi-annual pilgrimages, at the hands of peasant hunters. ${ }^{5}$ Periodical migrations of the sort here described are unknown among the moose of America.

We cannot wonder that the German name of the elk was interpreted as meaning "misery," or that Prof. Oken denominated the animal "ein melancholisches Tier," when we read of the diseases and parasites which attack him. Blasius says that about every tenth year elk suffer seriously from malignant anthrax (milzbrand), rinderpest, and scour, traceable perhaps to the effects of seasons of drouth; that they are subject to pulmonary and other diseases to which ruminants generally are exposed; and that many sorts of parasites afflict them, often with serious results. ${ }^{7}$ In I75I all the elk on the great island of Oesel in the Baltic Sea died of milzbrand; in $175^{2}$ the disease carried off

$s$ Martenson, p. 100.

${ }^{6}$ Allgemeine Naturgeschichte für alle Stände (Stuttgart, 1838), vol vii., p. 135 .

7 Uoi supra, p. 278. 
nearly all the elk of Courland, as well as many domestic cattle, and in more recent years Livonia and East Prussia lost many animals from the same cause. $^{8}$

Kapherr describes among other insect pests which attack the elk an "elk fly" (Ornithobia pallida) which torments the animals severely, especially in summer and early fall. The same insect attacks men. It is like a louse, and is with difficulty combed from the hair, while the sting causes serious inflammation. Elk hunters in Russia are advised to wear their hair cut short, for this reason. ${ }^{9}$ These and many other species of ticks and parasitic insects which persecute the elk are annoying, but not dangerous to the life of the animals. They first secure a lodgment in the hair, and then attack the skin and suck the blood. It is said the moose birds, or Canada jays, in America sometimes come to the relief of the moose by catching and devouring such insects.

The worst insect pests with which elk have to contend are certain varieties of bot-flies. These include the Cephenomyia ulrichii and Pharyngomyia picta. The first of these, commonly called Hum-

8 Kapherr, Das Elchwild_(Berlin, I908), pp. 44, 50.

- Ubi supra, p. 36. 
melfliegen, are said to be known in America. ${ }^{\text {ro }}$ The winged females of these pests surround and torment the elk in the spring, and deposit their larvæ in his nostrils, causing inflammation. The larvæ spread through the nose and throat, and even the larynx, interfering with the victim's breathing and with swallowing. When fully grown (at the expense of the elk, of course), these parasites leave their host by the nostrils or mouth, and change into their chrysalis form in the earth. If in poor physical condition, elk are not infrequently killed by this agency. In the southern portions of the elk's European range these attacks seem to be most frequent. The presence of these parasites is generally indicated by the elk coughing, which is noticed early in March. Dissection of victims often discloses masses of the maggots in the windpipe.

Many efforts have been made to domesticate the elk, and with varying degrees of success. "In the reign of Charles IX. [of Sweden] elk were made use of for the purpose of conveying couriers, and were capable of accomplishing thirty-six

"Martenson, p. 47. Hummelfiege may be translated "drone-fly"; it is not, however, the common drone-fly of America (Eristalis tenax). The latter is of the family of Syrphida, while the bot-flies are of the family of Estrida. 
Swedish (about 234 English) miles in a day, when attached to a sledge." II The seven-years' reign of Charles IX. ended in I6II. The use of elk in harness in Sweden and Norway is said to have extended over two or three centuries.

\section{Deonagris, ,eu alcibus, in $n$ currentibus.}

\section{CA P. $\times \mathrm{XX}$}

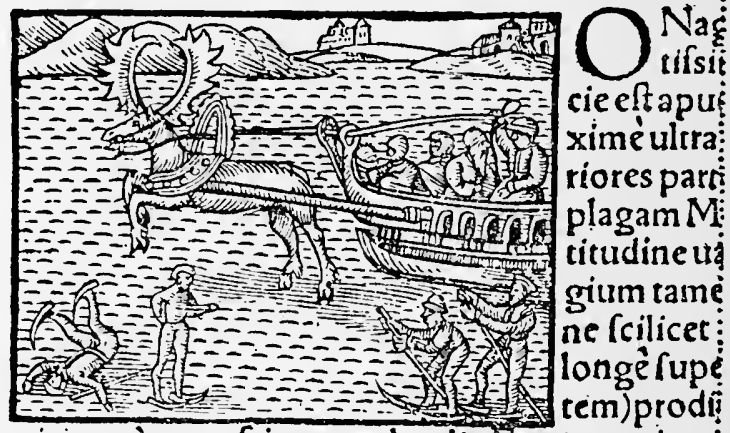

micis quàm ocy/sime reuclandis. Famis etenim, ă tuec beftia, ut diem noćemós immenfa fpatia du:

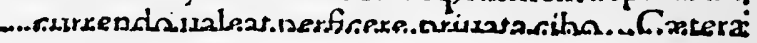

Sledge Drawn by Elk (Magnus, 1555)

Olaus Magnus, Archbishop of Upsala, in his History of the Northern Peoples, tells of the use of the elk as a draft animal in Scandinavia. "In Sweden," he writes, "great speed is made by wild asses, or elk, on the snow-covered ice, especially beyond the royal city of Holmen, toward the ' Jardine, Naturalists' Library (Edinburgh, 1835), vol. xxi., p. I3I. 
extreme north. Toward the south, although they are found in large numbers in the great forests, still, on account of a royal edict they are not used, lest traitors employ them, by reason of their speed, which greatly exceeds the speed of horses, to expose the interior of the kingdom to the enemy. This beast endures hunger, thirst, and work most patiently, so that in a day and a night he is able to accomplish by running the great distance of 200 Italian miles, without food."12

Concerning the use of elk as draft animals in Russia we have little information. A seventeenthcentury ordinance of the city of Dorpat, in Livonia, forbade such use of the elk within the city limits - presumably to avoid frightening horses. ${ }^{13}$

According to Blasius repeated efforts to raise elk in captivity in parks in various German cities have yielded unsatisfactory results. They have lived from one to four years at most. But Russian experiments have been more successful.

A writer in Priroda $i$ Ochota, a periodical devoted to hunting, published in Moscow, related his experience with two elk which were born wild, but which came into his possession June 8,1870 , as

2 De Gentibus Septentrionalibus (Basel, 1567), p. 484. This history was originally published in Rome in 1555 , while the author was living in Italy, practically in exile because of the Reformation.

${ }^{3}$ Martenson, ubi supra, p. 70. 
young calves. For the first day or two they nursed greedily from a bottle, he said, and then were given over at meal times to a cow whose calf had been taken from her. Soon the animals became accustomed to each other, and when, five months later, the two elk were taken from their foster mother the cow seemed quite distressed at their loss.

After the first fortnight various bitter weeds and twigs of mountain ash, aspen, and willow were offered to the two calves, to learn their taste; they were also gradually taught to eat oatmeal in milk. When three months old they were given rye bread, as well as crushed oats, but their favorite article of food was tansy (Tanacetum vulgare). For winter a large store of tansy was gathered and dried, and a great quantity of willow twigs. When the first snow came they were given the shelter of a stable. Every morning they were turned loose for exercise. They then browsed on the willow, eating the more slender twigs, but only the bark of the larger sticks.

The two calves were very playful, came when called, and welcomed attentions from grown people, but wished nothing to do with children.

In the spring the two young elk began visiting the neighboring village, belled like cattle. Their dislike for children continued, but after one of 
the boys of the village had been knocked down by a pair of angry hoofs the children ceased to approach them. Their feed was now marsh hay, tansy, two or three handfuls of oats, and twice a day a dish of willow bark steeped with oatmeal. In addition they frequently received bread from members of the household. They were often admitted to the house, where they were given free range to roam about. It was necessary, however, to cover a certain mirror, for both betrayed a disposition to attack their reflection in the glass with their hoofs whenever they saw it. At such visits they always received pieces of bread, and soon they learned to make straight for the house in the morning, ascend the six steps of the porch, and beat on the door until bread was brought to them. They drank little water, even in summer.

They were returned to their enclosure in the garden in May, r87r, but at first seemed lonesome, eating only when people were present, and making unmusical calls when left to themselves. They ate whatever was offered to them, including apples, cucumbers, and cabbage leaves, but always preferring tansy, which they would eat, roots and all.

They visited the village freely in the winter of I $87 \mathbf{I}-72$, especially certain houses where they had been given delicacies to eat. At one house they 
were accustomed to receive bread spread with honey, and if on entering they could not find their host they made nothing of going up stairs in search of him. At the village inn they were entertained by the innkeeper's son, but one day, in the son's absence, when they stood knocking at the door, the father drove them away with a whip. His back was scarcely turned when they came back and shattered the door with their hoofs. The owner of the elk paid for the needed repairs, and the elk continued their visits. They were in good health through the winter, except once from an unknown cause their bodies became bloated, but this was relieved by rubbing and by an injection.

In March, 1872 , the female lost her life in a frolic with her brother. They enjoyed throwing each other down in playful attacks, but one day the young female was accidentally thrown through the latticed cover of a well and killed. The young bull stood as if transfixed at the sight, until he was led away. For a week the survivor made many visits every day to the well, seeking his playmate, and endeavored in vain to raise the new and heavier cover which replaced the broken one.

Two "spikes" grew from the forehead of the young bull in April, I872, attaining in two weeks a length of more than four inches. Twice a year, 
when the antlers were growing and when they were cast, he seemingly suffered much discomfort, and lost a quantity of blood, but recovered his health and spirits quickly.

Complaints were made of the elk's misdemeanors by certain beggars who made a practice of carrying the proceeds of their mendicancy in sacks on their back. The elk considered himself entitled to a share of the charitable gifts, and whenever he saw anyone with such a sack he ran to him, seized the sack and pulled at it until the bearer was thrown down, unless the latter preferred to surrender the sack voluntarily. The elk would put his nose in the sack and make short work of the contents, and then seek another victim. After these complaints the highway robber was kept in confinement, but often escaped through a gate carelessly left open. The beggars soon learned to protect themselves from the elk's attacks by providing themselves with dry bread crusts for the robber, and keeping the sack out of sight. ${ }^{\mathrm{I}}$

In his relations with dogs the elk showed considerable tact. If they surrounded him and

\$4 A Russian writer in Die Jagd (Berlin, Sept. 2, 1906) relates how a tame elk, to gratify a fondness for mushrooms, would seek out peasant women who were gathering mushrooms in the woods, and after putting them to flight would eat the contents of the baskets which in their anxiety to escape they left behind. 
barked till they were hoarse, he merely went slowly from one to another with lowered head, and sniffed, but never ran away.

At three years of age, in 1873 , the elk was larger than his mother, and in good health, but with inferior development of antlers. He continued tame, was fond of being combed on the breast and belly, but would not suffer much handling of his back. ${ }^{15}$ He was fond of human society, and in the fall, with a pair of Newfoundland dogs, and sometimes a couple of bird dogs, would accompany the family when out for a walk. The party would frequently walk three versts (about two miles) to make a call, the animals remaining at the gate. The elk on such trips would never leave the party. The elk's antlers had only $2+\mathrm{I}$ points in $\mathrm{I} 873$, and $2+2$ in 1874 .

The writer tells little of the elk's later years. A change of residence compelled the owner to part with him in September, I884. The animal was then I4 years old. He subsequently found a home in the zoölogical garden at Moscow, but it is

15 Münster wrote in 1554 that elk could not be made to carry a load on the back ("nec possunt quicquam ferre in dorso"), and other writers have described the elk crouching on his haunches to free himself from the burden of a rider. On the other hand, Baron von Kapherr says that his cousin could mount and ride a tame bull elk without objection on the part of the latter, but any attempt to fasten a saddle on his back by a girth met violent resistance. 
not known to what age he attained. In conclusion his former owner wrote: "It seemed to me that this strong animal was fully conscious of his strength, but never misused it." ${ }^{\prime 6}$

Alfred Edmund Brehm, the German zoölogist, describes his experience with a captive elk. The animal was kept in an enclosure separated from a garden by a wall two meters (about $6 \mathrm{~T} / 2$ feet) in height. When he wished to visit the garden the elk would crouch on his haunches beside the wall, put his forefeet on the top, and with slight effort throw himself over. He never sought to escape beyond the garden. ${ }^{17}$

× Martenson, $u b i$ supra, pp. 72-78.

× Tierleben, $2 \mathrm{~d}$ edition (Leipsic, I877), vol. iii., p. II5. 


\section{CHAPTER XVI}

HOW THE ELK IS HUNTED

OF the various methods of hunting elk in the Eastern Hemisphere, the method which is most common in the Western Hemisphere is probably the least practiced. This method is still-hunting, or stalking. Still-hunting makes too great demands on physical endurance to be attractive to a large class of European sportsmen. Furthermore, it is objected that the rough timbered mountain-sides of Norway, and the low marshy thickets of the Baltic coast, are too difficult of access for successful stalking.

Many European sportsmen, indeed, fail to catch the true spirit of still-hunting in the quest for big game. Captain C. R. E. Radclyffe, an Englishman, thus wrote of a moose hunt in Alaska: "A more monotonous, uninteresting, and often tiring performance I have never indulged in, the only skill required being such as is supplied by a sharp pair of eyes and ears, in addition to the power 316 
of creeping about quietly-in fact the most elementary principles of hunting, and the element of chance existing so strongly that it is merely a matter of 'bull-headed luck' if you come across a bull moose with a head measuring forty inches or seventy inches. . . A Any intelligent being can master the principles of moose-hunting, as carried on in the Kenai forests, after two days playing at being his native's [guide's] marionette, to such an extent that he is fully capable of going and killing his own moose single-handed."'

Evidently Capt. Radclyffe learned little from his guide of how the moose should be huntedlittle of the animal's habits, and little of the significance of the many "signs" which abound in good moose cover. Perhaps the guide himself was unskilled; if so, and it was the captain's first moosehunting trip, his own skill would not be much greater at the end of two days in the moose country. As for luck, it is a factor, but a minor one, in the still-hunting of an intelligent and experienced sportsman or guide.

Abel Chapman, in a chapter on "Norwegian Elk Hunting" in Big Game Shooting, ${ }^{2}$ writes: "It will be obvious... that an animal, found 
only in evergreen forest, where no clear view can be had beyond Ioo yards, and often far less, cannot be stalked. For 'stalking' presupposes that the game be first spied at a distance, which, in this case, is impossible." But many of us who have still-hunted moose in the American woods, have spent hours perhaps (without a dog, of course), on the fresh "works" of a promising bull, only to lose him in the end without even a sight of the coveted head, simply by the accident of a stick broken under a foot carelessly placed. We called it still-hunting, or stalking, and enjoyed the sport keenly. But either we or Mr. Chapman must revise our definition of "stalking."

One who is fond of dogs will no doubt find much enjoyment in watching a good dog as he tugs at the leash on the fresh track of an elk, but he will perhaps begrudge the four-footed hunter the share of credit which will be his due if success is attained.

Occasionally in Russian preserves elk become accustomed to the sight of farm wagons on the forest roads, and remain undisturbed while a wagon passes within easy gunshot, but move away if anyone approaches on foot. Hunters sometimes take advantage of this fact, and hunt from such wagons-and this is as near an approach to 
stalking as is known in many portions of the elk's Russian domain.

Hunting with a well-trained dog is the favorite method of seeking the Scandinavian elk. The dog, a sort of spitz, is commonly kept in leash: indeed, the use of the "loose dog" is now illegal in Norway. A windy day is preferred: the dog gets the scent of the game quicker, and the elk is less likely to hear his pursuer, when there is a fresh breeze. In a sort of breastplate harness the dog cautiously follows a trail; when at close quarters he is usually tied to a tree and left, while the hunter stalks the quarry alone. By this method nine-tenths of all the elk killed in Norway are taken, and the system certainly makes hunting easier where the chase is in open timber in a season of bare ground.

"A blank day in Norway may be full of excitement," writes Hesketh-Prichard, "for there the hound is a living barometer, giving warning of the nearness of the elk, which he can wind at a great distance, often leading the hunter to a fresh track a mile off."3 An ill-timed whine, or a broken leash, may spoil the hunt, however, and the hunter will blame the dog; or the hunt may succeed, and the

3 Blackwood's Magazine, Aug., 1908; see also Blackwood's for July, 1906. 
dog, in such case, will usually be entitled to the major part of the credit.

Swedish elk hunters generally employ the "loose dog." The dog is left to range free: when he strikes a trail, if well trained, he follows silently until he brings the elk to bay, then he seeks to hold the quarry, barking, until the hunter comes up. The chase may lead over the roughest sort of country, and many hunters would find it too exhausting, for the dog should be closely followed, and his zeal may take him many miles before he gives up the pursuit. This system of hunting is subject to the drawback that after a long hard chase the dog may be completely lost to sight and hearing, or the quarry may be found to be merely a cow elk, or a spike-horn. ${ }^{4}$

The Russians have a kind of dog called "laika," with pointed erect ears, thick hair, and wollike appearance, which when well trained is a valuable aid in hunting elk or bear. These dogs are found throughout northern Russia and Siberia, and are employed to watch the herds of reindeer, and to draw sledges, as well as in hunting. Only certain of the laiki are useful in the sport, however, special training being important. They are kept in

4 Chapman, ubi supra, p. 127. Pottinger, Big Game Shooting (London, 1894), vol. ii., pp. 136-143. 


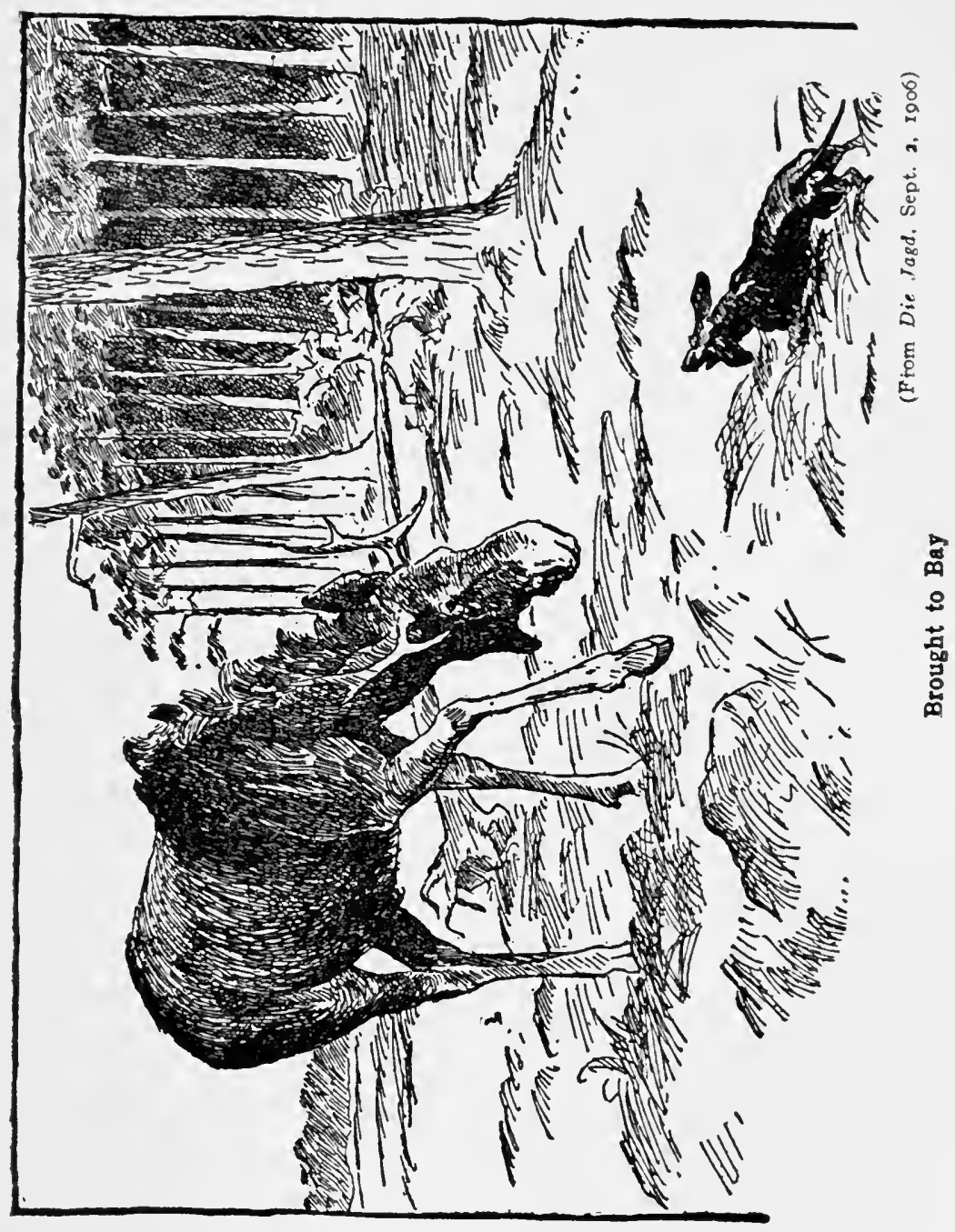


leash, and when a fresh track is found they follow quietly until they are near the quarry, when they are released, and soon bring the elk to bay. Their duty is to hold the elk's attention by springing about, seeking to bite him, first on the hind legs, then on the nose, until the hunter, in response to the dog's barking, comes up with his rifle. The dachshund also is well adapted by nature to assist in this class of hunting. ${ }^{5}$

The use of dogs in hunting elk is looked upon with growing disfavor in Russia, because of their tendency to frighten all classes of game, driving even the elk from their accustomed covers, perhaps never to return. In place of dogging, the hunters of the Baltic provinces now employ driving in some of its forms almost exclusively when they go in quest of elk.

Baron von Kapherr $^{6}$ describes an elk drive in Russia, quoting from the Neue Baltische IV aidmannsblätter. Seven sportsmen took part. Two were armed with rifles, two with shotguns carrying round ball, and three with shotguns loaded for hare, and they were placed at proper intervals in a long line. The first line of beaters consisted of five

5 Martenson, p. 135; Kapherr, pp. 86-88.

${ }^{6}$ Ubi supra, pp. 82-84. 
forest helpers, who advanced without making a noise. About 150 paces in their rear fourteen beaters followed, whistling and clapping their hands. The purpose of the second line of beaters was to drive forward any game which broke through the first line, for the elk have learned the hazards of the drive, and often refuse to approach the line of guns, but seek to escape through the advancing line of beaters, or around its ends. For this reason a position on the flank usually affords the best opportunities for a shot. It is said that sometimes the animals even hide in thickets, hoping to be overlooked till the danger has passed.7

When the beaters had covered half the distance to the line of sportsmen, the nineteen men formed themselves into a single line, and went forward quietly the remaining distance. In spite of these precautions a number of elk broke through the line of beaters and escaped. Such a drive is always conducted down the wind. The human scent is often enough to send the elk in the desired direction, unless the game has become familiar

7 Martenson (p. 65) tells of an old elk which had survived a number of drives, and had learned the trick of breaking through the line of beaters early in the drive, and seeking safety in the rear. At last the guns were stationed behind the beaters, and by this device the crafty veteran was brought to bag. 
with the system of hunting, and suspects an unseen and unscented danger ahead.

In this instance three drives were undertaken. The amount of territory covered could not have been great, for a late breakfast was served in the woods after the second drive. The narrator referred with some disparagement to the weapons used by the other sportsmen. He had a position on the flank, and three elk, a fox, and a heathcock fell to his gun. The first elk was a spike-horn; the second a cow, limping from old wounds in the legs inflicted by a poacher's shotgun; the third, a bull of undefined character. The latter succumbed to two I I-mm. rifle balls, which, for lack of more rifle cartridges, were followed by a round ball from a shot barrel at thirty paces, and that by eight shot cartridges fired from a knee rest, the elk standing, at fifteen paces' distance. One of the helpers tried to assist with a muzzle-loader, but the gun missed fire; another sent a charge or two of shot at the sorely-harassed animal. The elk, now unable to stand, still held his head up, awaiting the coup-de-grâce. For lack of ammunition the narrator of the story finished him with a thrust of a fourteen-inch knife blade behind the shoulder. Two bullets had taken effect behind the shoulder, and one in the intestines. The 
narrator does not undertake to describe the distribution of the pellets from those nine or ten shot cartridges, nor the part which they played in the outcome of the hunt.

It is to be hoped that all the participants answered at the roll-call when the drive, with its excitement and fusillading, was at an end.

If beaters are plenty and the number of guns limited, some of the beaters are stationed at the ends of the line of guns, and at right angles to it, to divert any elk which might otherwise escape; or some will be posted between the sportsmen on the firing line. Flags or other devices are sometimes suspended from the trees to guard the ends of the line, if the number of helpers is insufficient. ${ }^{8}$

A variation of the drive, often practiced in Russia for the benefit of an inexperienced hunter, is called "circling." It is most successful when the ground is covered with snow. The hunter is posted on a trail frequented by elk, and several beaters form a sort of circle, one slowly and quietly following the trail toward the hunter, while the others seek to direct the course of any elk which may be encountered into the trail, but without frightening the game. This expedient is likely

${ }^{8}$ Martenson, p. 138. 
to succeed in territory where elk are accustomed to the sight of men, and hence are not timid. The beaters or drivers must be familiar with the habits of the game, and must possess skill and patience, if they would bring an elk within gunshot of the hunter without frightening the animal out of a walk. 9 Like many other systems of hunting in Europe, this system is designed to aid sportsmen who do not possess the skill and power of endurance needed for successful stalking.

Another variation, when beaters are few, is to station the guns at a number of trails, while a helper leads a hound to the farther side of a section of good elk cover. The release of the hound is followed, when he strikes a fresh elk trail, by the music of his excited bark. As the baying draws nearer it tells the hunters to be ready for a possible shot. ${ }^{\text {Io }}$

Elk drives have long been a means of entertaining royalty and royalty's friends in Sweden. Such a drive, organized at the command of King Frederick I. of Sweden in September, I737, lasted four days. One wing was 27,690 paces in length, and the other 24,675, the base being 9300 paces. The accounts do not tell how many persons took part, but the bag

- Kapherr, pp. 88-9o. xo Kapherr, p. 86. 
included six bears, three wolves, three lynxes, one fox, and twelve elk, besides many hares and birds. ${ }^{\text {I }}$ Edward VII., as Prince of Wales, visited Sweden in I885, and was entertained by a gigantic elk drive. Preparations were begun weeks beforehand, many hundred beaters being employed in "sweeping with a gigantic cordon, which was never relaxed by day or night, an enormous extent of forest, and moving the elk gradually to the stations of the guns." In a single day forty-nine elk were killed. Three years later, in the same forest (at the southern extremity of Lake Wenern), sixty-six elk were killed in three drives on a single day. ${ }^{\mathrm{x} 2}$ Some excuse for this slaughter was found in the fact that the elk had been damaging the young Scotch firs in the forest.

Calling as a means of hunting elk is practiced to some extent in southwestern Russia, but the caller imitates the short grunt of the bull. Indeed, some Russian writers deny that the cow elk is ever heard to make a vocal sound in the season of the rut.

It is usual, according to Kapherr, for some forest official to make a thorough inspection of the

× Lloyd, Scandinavian Adventures (London, 1854), vol. i., p. 308.

I Pottinger, in Big Game Shooting, vol. ii., p. 136 . 
elk cover a few days before the beginning of the rutting season, and ascertain the number of bulls to be found, and their favorite haunts. In the morning or evening, when the weather is favorable and the hunt is to be undertaken, the hunter takes his station, with the caller forty or fifty paces behind him. The latter then seeks by imitating the voice of a small bull to draw a larger bull within range of the sportsman's rifle. In addition to calling, various noises are made to imitate the actions of a bull challenging a rival to combat-as if an elk were pawing with his fore hoofs and beating dry brush with his antlers. These tactics are said to be often successful. ${ }^{13}$

A description of a September hunt in southwestern Russia by two sportsmen and a guide is given by Martenson.

The guide sounded the call. "We soon heard a breaking of brush, and two bulls appeared in the clearing. . . . Then at their left a cow elk appeared, followed by two more bulls. When the first two bulls saw the cow they began to roar, and to paw the ground with their hoofs. After a few minutes a large fifth bull came bellowing on the scene, and attacked the second pair of bulls, which were younger, and with such violence that 23 Ubi supra, pp. 60-66. 
they fled to the edge of the clearing. The large bull then attacked the two bulls which had first appeared, and a bitter contest between the three ensued, in which thrusts of antlers alternated with angry roars."

The fight raged furiously at fifty paces' distance from the hunters, one after another of the bulls being thrown to the ground, but quickly regaining his feet, and resuming the battle. The narrator was about to fire at one of the struggling elk, but the guide restrained him, saying that they should approach and fire at a shorter distance. The three men then advanced to within seven paces of the combatants, and the two sportsmen, each singling out a victim, fired simultaneously. Two more shots were fired at the third elk, and the three animals lay on the ground dead. ${ }^{14}$

Calling, by either the American or Russian system, is rarely practiced in Scandinavia. Lewis Lloyd, who wrote more than sixty years ago, tells, however, of elk in Dalecarlia being brought within gunshot by the music of a violin played in ambush. He does not tell us the favorite air of the elk. Probably the Swedish national anthem would do as well as anything. Captain Lloyd relates how an elk on one occasion charged into a

" Martenson, ubi supra, p. 150. 
thicket in which a violinist and a hunter were concealed, and seriously injured one of the men. ${ }^{\text {is }}$ We all feel that way sometimes, when we hear someone scraping the strings of a violin without knowing how to play.

In Siberia and a large share of European Russia the people in general have been in the habit of exercising, with more or less legal sanction, the free right of hunting. In the exercise of this right season, age, sex, method-everything but slaughter has been lost to sight. As a result there has been a great reduction in the number of elk to be found on both sides of the inter-continental boundary-a reduction which, unchecked, and aided by improved firearms, would lead to extermination. ${ }^{16}$

Pitfalls are much used by the peasants of Russia. Sometimes a series of pitfalls, with intervening barriers to lead the animals to their doom, are constructed by men who seek to make a living by the slaughter of game. Once a week, or perhaps only once a fortnight, the pitfalls are visited, and sometimes elk are found in them which have starved to death. Similar barriers are erected in Siberia, sometimes three or four miles long, with a number of openings at which snares and springis Field Sports of the North of Europe (London, 1885), p. 293. ${ }^{36}$ Martenson, p. 130. 
guns are placed, ready to destroy the passing animal when he comes in contact with a cord. ${ }^{17}$ These expedients are especially destructive of elk in regions like Siberia where the animals make semi-annual migrations, the seasons and the direction of their journeying being well known to the natives. Saltlicks, with blinds from which the professional hunter can kill the visiting game, are also employed.

Crust hunting, as in America in the time of the Indians, and with the assistance of dogs, is still common east and west of the Ural Mountains. To save gunpowder the slaughter is accomplished in some cases by the use of a knife attached to the end of a ski, the ski thus serving as a spear. In such cases females, heavy with young, are shown no special consideration. Hundreds of elk have been thus slaughtered in a single winter in certain districts of Russia-thousands in the various elk regions of the broad empire. Martenson tells of a landowner in eastern Russia who by crust hunting shot sixty-four elk in three winters, questions of age and sex being alike ignored. ${ }^{18}$

A writer in Tobolsk, western Siberia, quoted by Kapherr, says that poachers in that section hunt

${ }_{7}$ Ibid., pp. 130-131 ; Blasius, ubi supra, p. 276.

${ }^{8}$ Ubi supra, p. I33. 
elk from boats in spring and summer when the animals have taken refuge in the water from the attacks of insects. The boats are covered with the boughs of trees, and the slaughter is accomplished as the hunters thus shielded drift slowly down the stream. ${ }^{19}$ Another expedient resorted

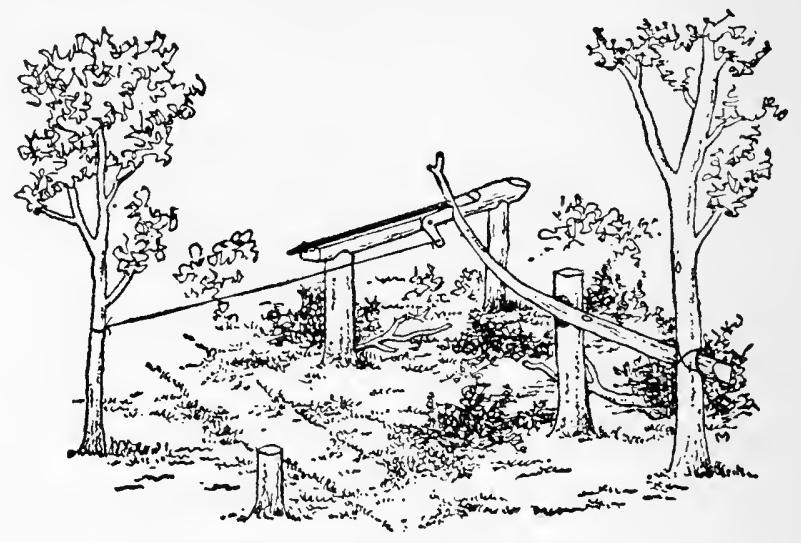

A Scandinavian Poacher's Device

to in Siberia in summer is a system of fire hunting. A boat is covered with green brush, and equipped with a raised wire basket in which pine knots are burned. At night the boat is slowly and silently paddled about in search of game. At sight of the fire an elk will stand and face it, until the hunter has come near enough to shoot. ${ }^{20}$

Lloyd tells of pitfalls formerly common in 19 Ubi supra, p. 34 . 2o Ibid., p. 88. 
Scandinavia, and also of a contrivance which was sometimes arranged beside an elk trail for killing the game automatically. A sapling was cut and trimmed, and attached horizontally to two trees, about four feet from the ground. The slenderer free end was bent sideways, resting on a rail fixed horizontally at right angles to the trail. The end of the sapling was secured by some trigger device, and a wire attached to the trigger was stretched across the trail. A heavy arrow or spear was placed in a groove in the rail, and when the elk pulled the trigger by striking the wire the bent sapling was free to drive the arrow into the side of its victim. Barriers, in funnel form, were usually erected, as often in the case of drives, to guide the elk to his fate. Incidentally the writer tells of instances in which woodsmen have been victims of this device. The use of such contrivances was illegal. ${ }^{2 x}$

"Scandinavian Adventures, vol. ii., p. 105. 


\section{CHAPTER XVII}

\section{ANTLERS OF THE ELK}

SibERIA and the neighboring sections of European Russia produce the best elk antlers taken in the Old World. Specimens from these sources exhibited in the great zoölogical museum in Petrograd, and in other Russian collections, have a spread of from 59 to 63 inches, with palmation reaching $\mathrm{I}_{2}$ and $\mathrm{r}_{4}$ inches, and sometimes as many as 30 points. Some of the best specimens, no doubt, were taken many years ago. In other parts of Russia, and in Scandinavia, antlers even approaching the least of these dimensions are becoming more rare from year to year. ${ }^{\mathrm{I}}$

The Siberian hunter, having only the demands of the market in mind, has sought hides and meat, indifferent to questions of sex and age in the quest of game. In consequence, Siberian antlers continue normal, showing none of the deterioration which is manifest in western Europe, where

I Martenson, ubi supra, p. 35. 
the protection of young males, together with the natural desire of the sportsman to secure the best possible trophies, has left for breeding only the elk with inferior antlers. Furthermore, the advanced agricultural conditions of western Russia and Scandinavia may easily have exerted an unfavorable influence, the elk being deprived of some

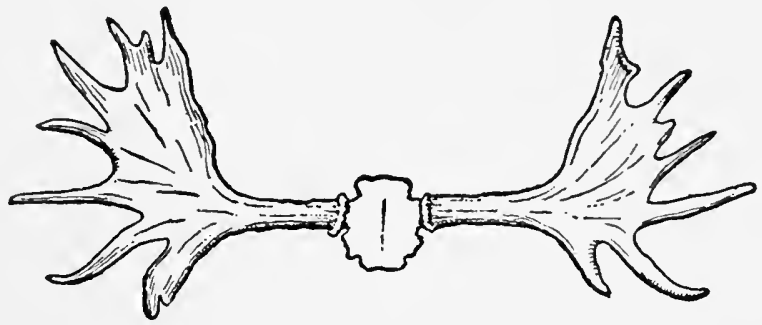

A Peculiar Siberian Type

of the articles of forage to which he had been accustomed.

Many Siberian antlers are notable for long and heavy main beams, resembling the fossil antlers of the long-extinct Alces latifrons of western Europe. The main beam of the Siberian specimen here illustrated is more than eight inches in length between the burr and the beginning of the palmation, and it has a circumference of $7 \frac{7}{8}$ inches. The extreme spread is 52 inches. $^{2}$

2 Martenson, ubi supra, p. 35. These antlers are the property of E. Büchner of Petrograd. They were taken in the vicinity of Krasnoyarsk, Siberia. 
There is no evidence that the best Siberian or European antlers ever equaled the best which are now found in America. In a paper on the natural history of the elk, read before the Imperial Academy of Sciences of St. Petersburg March 24, I870, Johann Friedrich Brandt discussed at length the

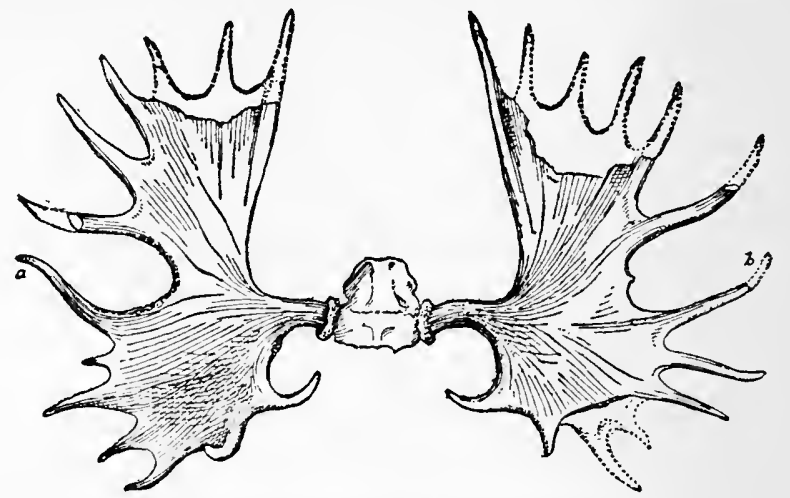

Fossil Antlers from Russian Poland

fossil remains of elk found in Europe and Asia. The best example of fossil antlers which had attained full development of which he gave an illustration was found beside the Bug River in Russian Poland. The river in a season of freshet had undermined the bank, and thus brought the antlers to light. In the same diluvial soil the skull of a rhinoceros was found. The greatest spread of the antlers (from $a$ to $b$ ) is supposed to have measured 58.II inches ( 1.476 meters). The 
smallest circumference of the larger beam is $81 / 2$ inches. ${ }^{3}$ These antlers were preserved in the zoölogical museum in Warsaw.

The largest and most fully developed single fossil antler described and illustrated by Brandt was found in 1833 in the valley of the Rhine, south of Darmstadt, at a depth of twenty-one feet. It was deposited in the Darmstadt museum. The spread of the pair was probably about sixty inches. This antler has twelve prongs. They are somewhat shorter than those of the Polish specimen. The palmation reaches a breadth of a little more than twelve inches. ${ }^{4}$

At the International Hunting Exhibition held in Vienna in I9ro few elk heads taken in Russian territory were shown. The best heads from Scandinavian covers were from Sweden. The first prize for European antlers was awarded for a wellbalanced pair exhibited by Herr Rothmann from Murjeck, Sweden. They spread 53 inches, and

${ }^{3}$ J. F. Brandt, "Beitrāge zur Naturgeschichte des Elens in Bezug auf seine Morphologischen und Paläontologischen Verhältnisse, sowie seine Geographische Verbreitung, " in Mémoires de l'Académie Impériale des Sciences de St. Pétersbourg, seventh series, vol. xvi., No. 5, p. 19. See also G. G. Pusch (of Warsaw) in Neues Jahrbuch für Mineralogie (Stuttgart), 1840, pp. 70 et seq. More fossil remains of elk have been found in Germany than elsewhere in Europe. Very few have been found in England. In America fossil remains of moose are rare.

${ }_{4}$ See Brandt, ubi supra, p. I7; J. J. Kaup, Neues Jahrbuch für Minera. logie, 1840, p. 167 . 
had I2+II points. The circumference of the main beam above the burr was 7.9 inches.

Rowland Ward in his Records of Big Games describes sixteen European elk heads. The widest spread is credited to one from Norway in the possession of $\mathrm{H}$. J. Elwes, measuring 52 inches.

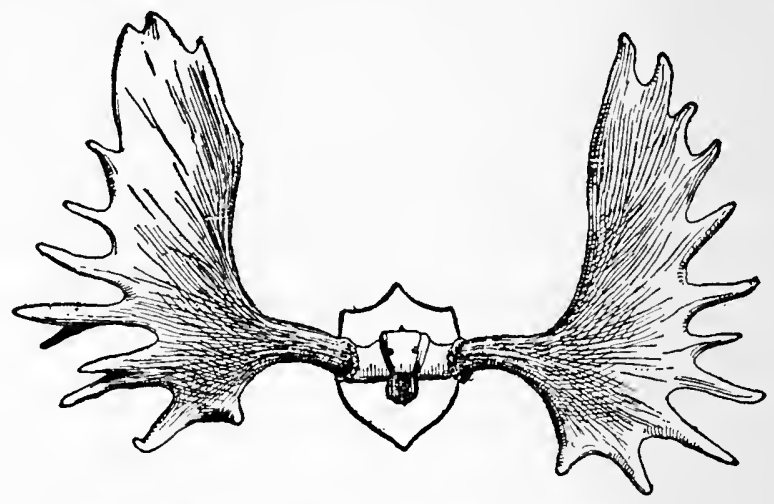

Best Elk Antlers at the Vienna Exhibition, rgro

A better head, also from Norway, belongs to Capt. Gerard Ferrand, but measures only $513 / 4$ inches. It has $10+10$ points, with palm $15 \%$ inches in breadth, and the circumference of the beam is $81 / 2$ inches. "Anything spreading over 40 inches may in Norway be termed a good head, as is anything over 50 inches in Canada," wrote H. Hesketh-Prichard, "but the number of 50 -inch heads shot in Canada is far more in proportion to

s Seventh edition, London, 1914. 
the total killed than is that of 40-inch heads to the total killed in Norway." 6

Two Swedish heads are described by Ward, spreading 49 and 46 inches respectively. The latter, belonging to Capt. Ferrand, has rot io points, I I I/2 inches breadth of palm and $71 / 2$ inches circumference of beam. A fine specimen of Scandinavian elk antlers presented to the New York Zoölogical Society by William T. Hornaday in 1906 spreads 45 inches, and the breadth of palmation is 9 inches. There are $\mathrm{I}+\mathrm{I} 2$ points.

The best Russian head described in Ward's Records belongs to Prince E. Demidoff. It measures 48 inches, has Io 9 points, II $1 / 2$ inches breadth of palm, and $83 / 4$ inches circumference of beam. It was taken near Petrograd. Better heads, taken in the government of Minsk, in West Russia, are mentioned by J. G. Millais in an article on "The European Elk and Its Horns," in Country Life (London, July 30, I9I0). European antlers in general show less tendency to the formation of a distinct group of brow prongs than in the case of the moose of America.

The development of the antlers is naturally less rapid in the elk of western Europe than in the case

' Blackwood's Magazine, August, 1908. 
of the moose, for the ultimate development when the animal is in his prime is inferior. In his fourth year, writes Martenson, the elk is still a crotchhorn. In the fifth year the number of points varies from four to six, and there is a slight tendency to palmation. In the sixth year the normal formula of antlers is $3+3$, with a little broader

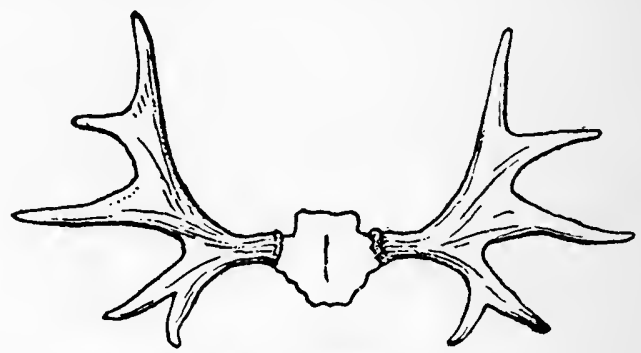

An Eight-Year-Old from Livonia

palmation. In the seventh year the number of points is generally from six to eight; in the eighth from eight to ten; and in the ninth from ten to twelve, of which from four to six will be in the brow groups. In the tenth year the antlers usually have from twelve to fourteen points. After the elk's ninth or tenth year variations from the normal in antler development become more marked, but until the sixteenth year there is increase in the strength and weight of the antlers, together with increase in palmation, while the prongs become 
shorter and their number remains variable. After the sixteenth year the development will show retrogression. In very old elk many of the prongs become short and blunt, and often merely scallop the outer edge of the principal blade; the brow prongs, however, continue to be well developed. ${ }^{7}$

It would seem that the time when the antlers

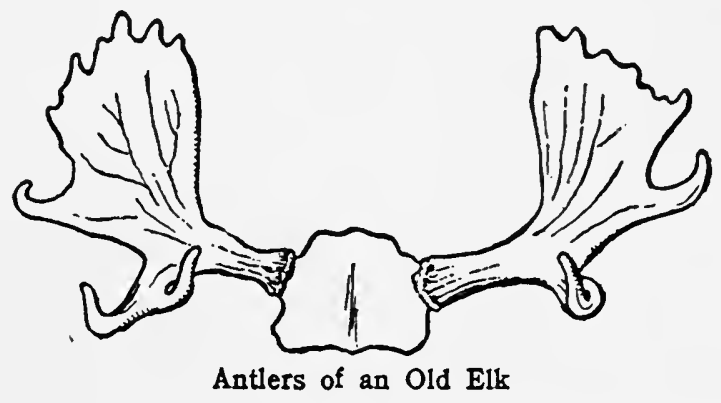

of elk begin growing, reach maturity, and finally are dropped is more variable than in the case of moose. Martenson was assured by some sportsmen from Petrograd, who had been bird shooting in the government of Novgorod, that they had seen three mature elk, on the 12th of April, 1903, which had not yet cast their palmated antlers. This, however, Martenson considered a rare occurrence. $^{8}$

7 Martenson, ubi supra, pp. 30-31. Martenson was writing in Livonia, southwestern Russia. His statements would probably require some modification in other parts of the empire.

8 Ubi supra, p. 32. 
"In general it may be said that spike-horns and crotch-horns drop their antlers from November to March, inclusive; older elk, from November to February; and those with best developed antlers, from October to December."' These dates are earlier than in the case of the moose, or of the elk of Scandinavia.

In captivity the time of casting the antlers shows greater variation than when the elk is in the enjoyment of his freedom. An elk called "Puck" was kept in a private park near Dorpat, in Livonia, Russia, until his tenth year, when he was gored to death in a fight with a male red deer (Cervus elaphus). The character of his antlers for each year of his life, and the dates when they were dropped, are given below:

Age,
Years

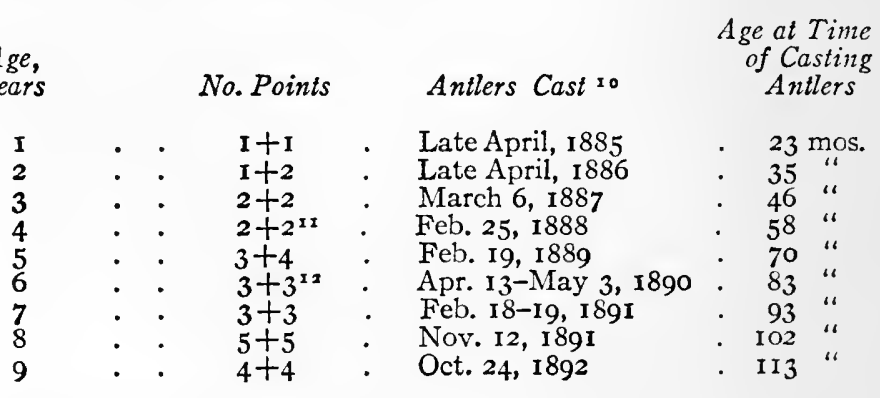

Age at Time of Casting

9 Martenson, ubi supra, p. 33 .

10 Martenson gives the dates according to the Russian calendar. They are here reduced to the "new style."

$\therefore$ Heavy flat prongs.

12 Heavier than the antlers of the previous year. 
The heaviest antlers were those at eight years of age. There were then ten points, $2+\mathrm{I}$ of which were brow or "fighting" prongs ("Kampfsprossen"). A picture of "Puck," which is given as a frontispiece in Martenson's book, shows him at eight years of age in his park, the wildness of which seems to approach closely to the natural forest conditions in which an elk may be expected to thrive. ${ }^{13}$

At a meeting of the Zoölogical Society of London Feb. 18, 1902, Richard Lydekker exhibited the skull and antlers of an adult male elk "from Siberia," which were commented upon as remarkable for the practical absence of palmation of the horns. Mr. Lydekker placed the age of the animal at "at least six or seven years," the cheek-teeth being about half worn. "Mr. Lydekker had been informed that other elk antlers from Siberia were of a similar type." Considering the lack of palmation as typical of Siberian specimens, Mr. Lydekker was inclined to regard this variety as a distinct species. He accordingly gave the name Alces bedfordice to the species, in honor of the Duchess of Bedford, wife of the president of the Zoölogical Society. "The occurrence in Siberia s Martenson, p. 33. 
of an elk with antlers of the simple type of those exhibited was a fact of considerable interest, since that country was probably the center whence both the European and American races of the true elk were evolved." ז4

But Martenson, more familiar with the elk of European Russia and Siberia than any English

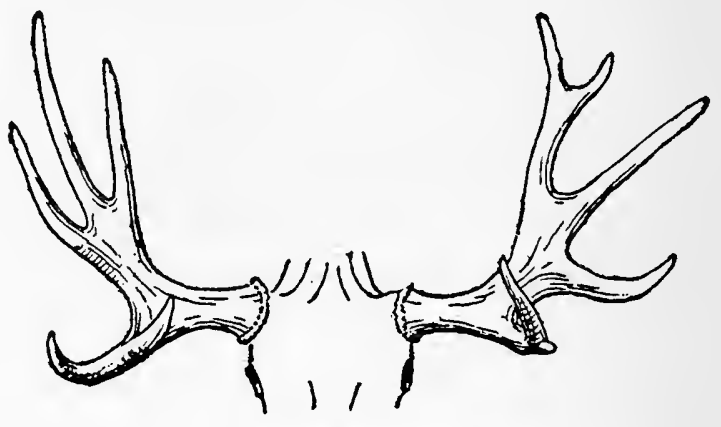

Alces bedfordiae

writer, declares that the unpalmated antlers are characteristic of certain sections of European Russia and Scandinavia, but are practically unknown in Siberia. The absence of palmation he associates with the encroachments of civilization and agricultural improvement in the habitat of the elk. Such change in antlers, he remarks, has never been observed in the wilds of Siberia. Moose antlers equally devoid of palmation are ${ }^{14}$ Proceedings of the Zoölogical Society of London, 1902, vol. i., pp. 107-I09. 
occasionally found in America. Such a pair from Manitoba is illustrated in Ernest Thompson Seton's Life Histories of Northern Animals, vol. i., p. 156.

Mr. Lydekker failed to give the history of the particular specimen upon which he based his classification of Alces bedfordia, and Mr. Martenson may after all be right in assuming that it had its origin in European Russia, "of the existence of which," he says, "Mr. Lydekker seems not to be aware." The Englishman is commonly looked upon as a "lumper" by other naturalists, and he has disputed with some warmth the position of those who would treat the moose of America as of a different species from the elk of Europe. ${ }^{15}$

${ }^{15}$ See page 57. In Rowland Ward's Records of Big Game (seventh edition, 19I4), three specimens of the "East Siberian elk (Alces machlis bedfordia)" are described. The best has a width of $421 / 2$ inches, $6+5$ points, and $71 / 2$ inches circumference above burr. These antlers belong to Hon. Walter Rothschild. 


\section{CHAPTER XVIII}

\section{MISBELIEFS ABOUT THE ELK}

Among many ancient misbeliefs concerning the elk the most widespread, and generally the most remarkable, was that in which he was associated with epilepsy, both as a victim of the disease and as furnishing the means for its cure in human patients.

Peasant and scholar alike, the humble woodsman and the professor at the university, were convinced that the elk was often afflicted with the falling sickness, and the belief that he could cure himself when attacked by opening a vein in the ear by the hoof of one of his hind feet was for centuries unquestioned. The belief in this selfcure easily led to a theory that the hoof which could cure an elk could cure a man suffering from a similar ailment. Hence many treatments in which the elk hoof was employed were recommended by the regular practitioners of medicine of the olden time for human patients suffering from epilepsy. 
Olaus Magnus, writing in 1555 , endorses the elk hoof as a curative in excellent Latin. And he was very circumstantial in describing the method of securing it. It must be the outer half of the right hind hoof, he asserted, and it must be cut from the living animal after the middle of August. ${ }^{x}$ As described by Conrad Gesner, a celebrated Swiss naturalist, in 1551 , it was necessary for the elk to insert his right hind hoof in his left ear. ${ }^{2}$ Gesner's illustration shows a low-browed evillooking beast without horns, having short legs and long heavy body. If he could reach his left ear with his right hind hoof while in the midst of an epileptic convulsion he must have possessed acrobatic skill of a high order.

Samuel Friedrich Bock, however, in 1784 seriously controverted the belief in the elk's tendency to epilepsy, and his cure. He explained that the elk is uneasy at the time when the antlers are cast, by reason of an itching sensation in the ulcerated area at the base of the horn, and for this

x "Ungula exterior dexteri lateris, pedis posterioris, onagri masculi, qui non genuit, abscisa à vivo pede securi, vel alio instrumento avulsa post medium Augusti, spasmum, aut morbum caducum patienti adhibita continuo sanat."-De Gentibus Septentrionalibus (Rome, r555), p. 6or.

2 "Germanicum nomen miseriam significat; \& vere miserum est animal, si credendum est quod sæpe audivimus, quotidianum ei morbum comitialem ingruere, a quo non prius levetur quam dextri (si bene memini) posterioris pedis ungulam auriculie sinistra immiserit."-Historia Animalium (Zurich, I55I), vol. i., p. 3. 
reason scratches his scalp behind the ear with the hoof until the blood flows, seeking relief. Nevertheless Dahms quotes Bock as recommending the hoof of the right hind foot of the elk to cure this very ailment in men.

Many of us have seen a wounded moose, in extremis, striking rapidly, viciously, aimlessly, and perhaps only half consciously with his fore hoofs as he lies helpless on the ground and sees the dreaded hunter close at hand. It is this spasmodic movement, which is quite characteristic of the wounded moose, and which resembles the convulsions of an epileptic, that perhaps gave rise to the epilepsy fable. But this belief did not begin with Magnus and Gesner, nor end with Bock. It gained wider currency, and lived more persistently, than any other misbelief associated with any species of animal.

Lithuania was long the seat of an industry in healing tokens in which the hoof of the elk was employed, and the traffic extended as far as Italy. Rings were made from the horn substance of the hoof, and worn on the ring finger of the left hand, or pieces of the hoof were set in rings of gold and worn so that the curative medium would be in contact with the skin. Sometimes too the remedy 
was worn at the neck or on the breast. In other cases the hoof was scraped with a file, and the filings thrown into wine, and taken internally; or pieces were burned, and the smoke inhaled as a relief in cases of epilepsy and hysterics. ${ }^{3}$

In its time the most complete and highly es-

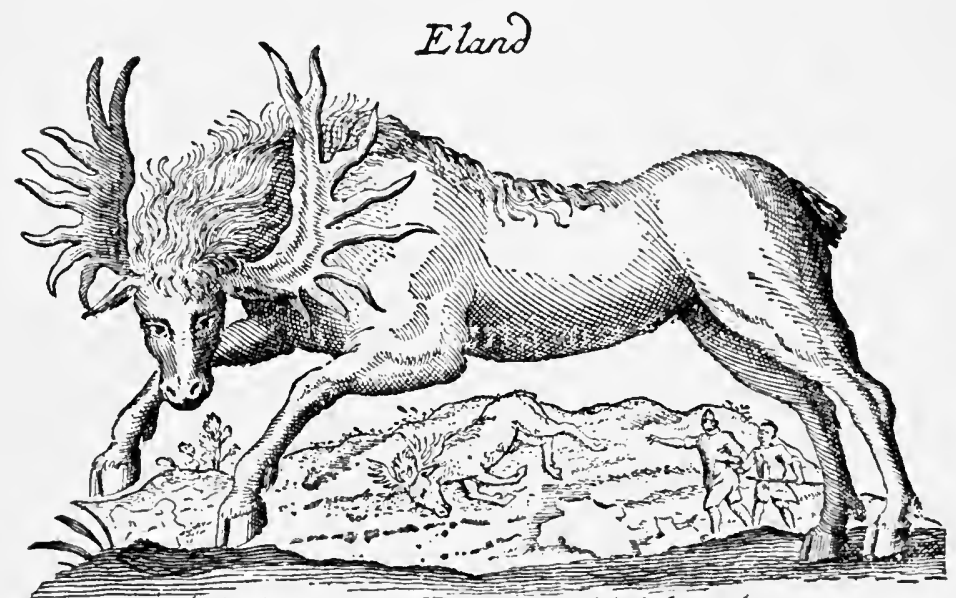

Eland tombc dw haut-mal estunt pour fuivi des Classeurs

Elk Attacked by Epilepsy (Pomet, 1735)

teemed treatise on materia medica in Europe was a work by Pierre Pomet of Paris. From this we learn that the elk is extremely subject to attacks of epilepsy, but is able to cure himself by putting his left hind foot into his left ear. To supply the drug trade with hoofs for use in the

3 Dr. Dahms made an exhaustive study of this subject, and to his article in Globus (vol. 1xxiv., pp. 219-220) the author is indebted for much of the information here given. 
treatment of similar human ailments, Pomet states, men in Lithuania went in parties of four, armed with the arquebus, and lay in wait for the elk in the woods. When they saw one in the midst of an attack of epilepsy, they would shoot simultaneously, but only to cripple the animal, for the hoof possesses its wonderful curative properties only when taken from the living elk.

The victim, helpless on the ground, was tied with ropes, and the hoof was then removed, after which the sufferer was dispatched, and the carcass dressed for the sake of the venison. Meanwhile a gunshot was fired occasionally to frighten away the rest of the herd, for we are assured that they are dangerous antagonists. ${ }^{4}$

Referring to the superstition in Europe regarding epilepsy among elk and men, and its cure, J. G. Bujack wrote in 1837 that the same false belief prevailed among the Indians in America, and that the belief in America had an independent origin, quite free from any European influence. ${ }^{5}$ Dr.

4 Histoire Général des Drogues, by Sieur Pomet (Paris, 1735), vol. ii., pp. 120-122. Pomet's elk bears a very close resemblance to Montanus's moose. See p. 20.

5 "Sonderbarer Weise herrscht in Amerika bei den Indianern derselbe Wahnglaube, und hat sich, auffallend genug, unfehlbar ganz unabhängig von dem Europäischen Einfluss, dort selbstständig gebildet." - "Naturgeschichte des Elchwildes oder Elens," in Preussische Provinzial-Blätter, vol. xviii., p. I 49 (Königsberg, I837). 
Dahms accepts Bujack's statement in this matter without comment. In a previous chapter, however, the present writer has ventured to question the independent origin of the belief in America. ${ }^{\circ}$

The hoof was not the only portion of the elk which possessed medicinal virtues. He was a walking drug store. His antlers, if secured about the first of September, were efficacious in cases of epilepsy; rings made from the antlers were worn as preventives of headache and vertigo; while still growing, and hence tender, slices cut from the antlers and steeped with herbs and spirits produced a remedy for snake-bites. The bone of the elk's heart, ${ }^{7}$ burned or pulverized, was prescribed for ailments of the heart; the fat yielded a valuable salve; his marrow, his blood, his bones reduced to ashes,-all had their uses in the healing art; his nerves dried and wrapped around an arm or leg suffering from cramp would prevent further attacks-and so on through a long and entertaining list.

No doubt all these remedies would be as efficacious today as they were two hundred years ago, and no doubt the hoofs and horns of the moose possess curative properties not surpassed by those of the elk of northern Europe.

6 See pages $263-267$.

' See page 268. 
Medieval practitioners of medicine-and the Middle Ages in the healing art have continued down almost to our own time-were perhaps no more dishonest than their successors today. Disease was a mystery, and it was believed that nature had given the key to the mystery in a system of symbols, called "signatures." It was the physician's function to trace the resemblances between symptoms of disease on the one hand and natural objects on the other, for such resemblances were the "signatures"- the signs and symbols which nature had provided-to guide mortals in the search for health. The physician whose knowledge of chemistry was gained in the alchemist's laboratory might honestly see in the distinction between the right hoof and the left a possible clue to one of nature's many secrets. Thus, groping in the dark as they were after the truth, the worst that can be said of the medical men of the later Middle Ages is that they failed to find it. And the ghost of the old superstitions still haunts the best regulated apothecary shops.

Ancient writers who gave accounts of the elk were as imaginative as any of the early travelers in America who left descriptions of the moose. The elk's size invited exaggeration, and a full 
century before Pontoppidan's time Olaus Worm described the animal as so large "ut sub ventre ejus quis stare valeret." "Worm referred also to the elk's timidity, saying that he would die at once at sight of his own blood, if even slightly wounded. ${ }^{9}$ It was said too that when running fast in the woods the elk carries his antlers in a horizontal position, his nose raised in the air, and that at such times he is unable to see the ground, and of ten falls for this reason. But how many men ever saw a moose fall when running, unless he was overtaken by a bullet? The Chinese have a familiar simile, lin chih chih, "as sure-footed as an elk," and certainly the elk deserves the compliment. Still another belief was to the effect that the elk drinks much water, which is heated to the boiling point in his stomach; and that if pursued by dogs he ejects this water at them, to drive them away. ${ }^{\text {Io }}$ "Among the peculiarities of this animal it may especially be mentioned that when the ground is very broken and soft he lies down, and seeks to

- ${ }^{8}$ See p. 280 . Old German writers declared that next to the giraffe the elk was the tallest of all species of deer. And it was a long time before they discovered that the giraffe was not a deer at all.

9 "Timidum animal est, advenientes homines fugiens, quovis parvo vulnere moritur, \& si suum viderit sanguinem exanimatur."-Worm, Museum Wormianum (Amsterdam, 1655), p. 337.

${ }^{10}$ Dahms, quoting Conrad Forer, Allgemeines Tierbuch, Frankfort, 1669. 
push himself forward with his feet." Georg L. Hartig, who wrote thus in $1817,{ }^{\mathrm{II}}$ was stating a belief which was quite common in his time. Some asserted that the elk was able to make rapid progress across swamps in this way, though only by the expenditure of great exertion. Bujack discredits the entire story, however, calling attention to many known instances where elk have been found helpless in swamps, and have escaped from their predicament only by the aid of men, who brought ropes for use in effecting a rescue.

As late as 1838 Lorenz Oken wrote: "It is said that the ermine creeps into the elks' ears while they sleep, and bites them so that in their frenzy they dash their heads violently against any object, or throw themselves over a precipice." "r2 This fable, the correctness of which Prof. Oken did not feel called upon to question, seems to be a survival, with variations, of a story told by Olaus Magnus 275 years before. "The ermine," he wrote, "often seizes the elk by the throat, and bites them until they bleed to death."

Since the elk first entered the pages of literature - on the jointless legs given him by Cæsar-he has been a creature of mystery, and travelers,

× Lehrbuch für Jäger, und die es Werden Wollen, vol. i., p. I63. × Allgemeine Naturgeschichte für Alle Stände, vol. vii., p. 1313. 
scientists, and, in a less degree, sportsmen have contributed to the misrepresentations which have been published concerning him.

The ancient Germans, in their days of paganism, revered the elk as a divinity, or, as Erasmus Stella wrote, as a messenger of the gods. From that time to this the great animal has never been reduced to the commonplace plane where the other forest creatures pass their humdrum existence. Thanks to his uncouth figure, his colossal size, and a disposition to spend his life in the retirement of thick woods, far from the sight of men, he has always been surrounded by a halo of mystery and misunderstanding. There are still many questions concerning the elk and the moose about which writers differ, but the number is growing less as modern matter-of-fact methods are applied to the study of zoölogy. 



\section{APPENDIX}

\section{A. \\ SOME NOTEWORTHY TROPHIES}

British Columbia's claims to a moose-head entitled to rank with the best Kenai specimens seem to be well founded. At page 182 a head is mentioned, "measuring more than 70 inches," taken in the Cassiar district by A. S. Reed, the English sportsman, and it is stated that the head had been accidentally destroyed. My informant was the Provincial Game Warden. In The Gun at Home and Abroad, vol. iv., "The Big Game of Asia and North America," (London, 1915), at page 237, John G. Millais writes of this head as follows:

"Mr. Warburton Pike, whose accuracy cannot be disputed, told me that he was hunting one season [about 1898] with Mr. A. S. Reed ... at the head of Dease Lake, British Columbia, when Mr. Reed shot a bull moose whose head was wider than any previously known. Both Mr. Reed and Mr. Pike measured it, and it was $8 \mathrm{I}$ inches across. They stood the head up against their wooden hut, and both went out to hunt. When they returned they found the hut and its contents, as well as the moose-head, a heap of ashes, the Indians having forgotten to douse the fire before leaving."

Assuming that this measurement was correct, there will still be a question whether, when fully dried, the spread of these antlers would have equaled the best Kenai specimens. The paims are said to have been not exceptionally wide. Data regarding the number of prongs, etc., are entirely lacking, and accordingly the Kenai trophies seem to be entitled to retain 
the place of honor which in recent years has been accorded them.

Alberta.-The best head ever secured in Alberta, of which I can find a record, is one in possession of Lieut.-Commander John G. Millais, the English sportsman and artist. The moose was killed on the eastern slope of the Rocky Mountains, near the head-waters of Peace River. These antlers have a spread of 65 inches, with $16+15$ points, and palms $161 / 2$ inches wide. The circumference of the beam, above the burr, is $7^{1 / 2}$ inches. Another Alberta head, with equally wide span but inferior palmation, is in a hotel in Banff.

Saskatchewan.-The best Saskatchewan head which I can find was taken by a man named Dergousoff at Usherville, in the northern part of the Province, in the autumn of 1917. The breadth of span is comparatively small -56 inches-owing to the tendency of the prongs to curve upward, but the formation is quite remarkable. There are $20+17$ points, the maximum palmation is $13 \frac{1}{2}$ inches, and the circumference of beam 8 inches. The weight of antlers and skull, without lower jaw, dry, is $58 \mathrm{I} / 4$ pounds. This head is owned by E. W. Darbey of Winnipeg. It is illustrated at page 222 .

Quebec.-Of a type radically different from the Saskatchewan specimen is one secured by William Darrow, Jr., of Summit, N. J. Mr. Darrow was hunting on the preserve of the Montagnais Fish and Game Club, of which he has since been president, in the Patapedia Lakes section of Quebec, September 5, I9II, when he killed a moose with antlers spreading $64 \frac{1}{2}$ inches. This spread has since shrunk to $623 / 8$ inches. The right palm has shrunk from $17 \frac{1}{4}$ to $153 / 4$ inches, and the left from 15 to $133 / 4$ inches. Aided by its profusion of points, however, this head would to-day outrank either the Gibb or the Caswell head (see page 186), if scored by the formula suggested at page 192. 



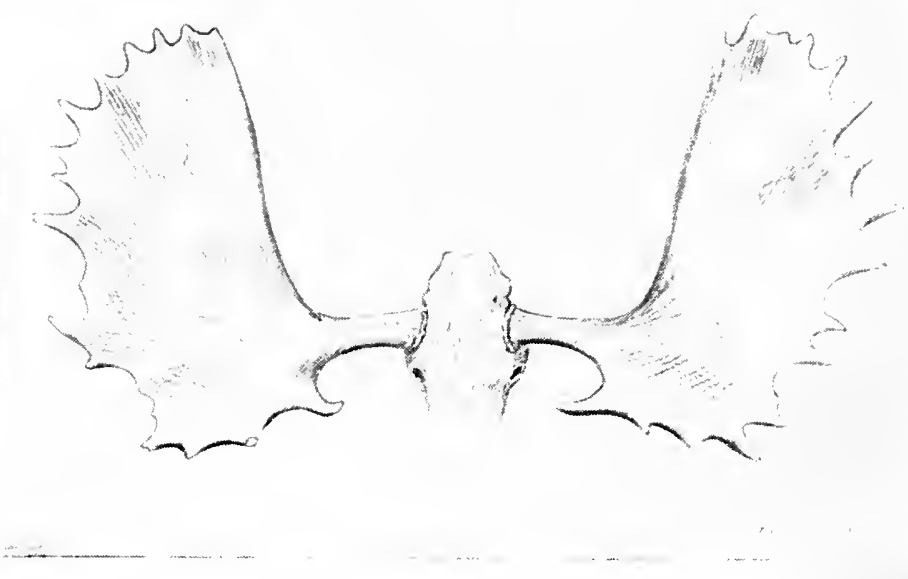

Mr. Darrow's Quebec Trophy

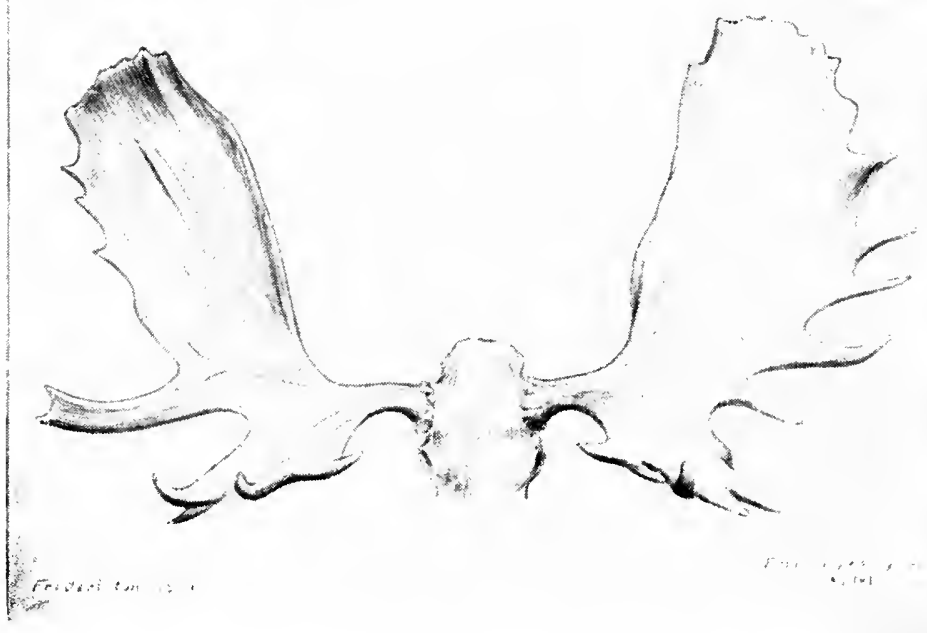

Antlers of a Restigouche Veteran 


\begin{tabular}{|c|c|c|c|c|c|c|c|c|c|}
\hline Spread & • & . & . & • & - & $\begin{array}{c}G i b b \\
69 \frac{1}{2}\end{array}$ & $\begin{array}{c}\text { Caswell } \\
62 \frac{1}{2}\end{array}$ & & $\begin{array}{c}\text { Darrow } \\
62 \frac{3}{8}\end{array}$ \\
\hline Points & . & . & . & . & . & 27 & 27 & $18+16$ & $=34$ \\
\hline Palmation & & . & - & - & . & 24 & 28 & $15 \frac{3}{6}+13 \frac{3}{6}$ & $=29 \frac{1}{2}$ \\
\hline Beam & $\cdot$ & . & • & - & • & 17 & I 5 & $7 \frac{1}{2} \times 2$ & $=15$ \\
\hline Totals & • & . & & • & • & $137 \frac{1}{2}$ & $132 \frac{1}{2}$ & & $140 \frac{7}{8}$ \\
\hline
\end{tabular}

The antlers of Mr. Darrow's moose are very symmetrical, and the area of palmation is exceptional. The bay, which usually separates the brow group of prongs from the main antler, is in each case lacking.

New Brunswick.-Some of the New Brunswick game offcials remark in recent years on the growing scarcity of good heads among the moose of the Province. Nevertheless, in his latest report the Chief Game Warden says: "Among the moose killed [in 1918] some fairly large heads have been reported, two of them measuring 64 inches, and quite a number between 56 and 60 inches."

The widest spread to which New Brunswick can lay claim is $715 / 8$ inches. Lazare Russell, a lumberman, living at Tracadie, N. B., encountered this moose near the head of the Nepisiguit River October 10, 1917, and when at close quarters shot it below the eyes. Three or four weeks later I saw this head at Davis's taxidermist shop in Fredericton. Except in respect to breadth of spread it is very ordinary. There are $9+$ I I points; the palmation measures $101 / 4$ inches right, $93 / 4$ inches left; circumference of beam, $65 / 8$ inches right, $63 / 4$ inches left. The antlers, and Charles Cremin, a Nepisiguit River guide, are shown in an illustration opposite page 187. Another fine head, in most respects superior to the Russell trophy, was taken on Restigouche waters the same season, by Joseph Arseneau of Charlo, N. B. I measured these antlers in Fredericton, in November, 1919. They spread 633/4 inches, and have $15+20$ points. The maximum palmation is $123 / 4$ inches right, I5 inches left; circumference of beam, 8 inches 
right, $9^{1 / 8}$ inches left. They are lacking in symmetry, the right antler being distinctly inferior to the left; and some of the prongs project curiously from the lower side of the blades. The blunt points on the portions of the blades remote from the head indicate old age, the blood vessels in the "velvet" having dried before the antlers had attained full development.

Nova Scotia.-J. A. Knight, K. C., Chief Game Commissioner, writing of the best moose-heads which have been secured in Nova Scotia, and which have come to his knowledge, mentioned one taken near Quinan, Yarmouth County, October 19, 1916, by Joseph Pictou, an Indian. These antlers spread $64^{1} / 2$ inches, and had 34 points. Mr. Knight was unable to obtain further particulars of this head, or a photograph of it. In the office of the Chief Game Commissioner in Halifax is the head of a moose shot near Trafalgar, Guysboro County, in 1910, by L. G. Ferguson of Westville, which has a spread of 59 inches, with 34 points. The breadth of blade of these antlers is $143 / 4$ inches right, $13 \frac{1}{2}$ inches left; circumference of beam, $75 / 8$ inches right, $73 / 4$ inches left. (See illustration, page 222.)

The different types of antlers here described are not characteristic especially of the sections where they were taken. The male progeny of any given moose, however, has a tendency to inherit the antler characteristics of his sire. The peculiarities are therefore individual, and are determineo in a measure by heredity, but indicate no difference of species, or of habitat. 
B.

\section{BIG-GAME REFUGES}

(See pages 37,378 .)

WRITERS in newspapers and magazines have frequently stated in recent years that moose are approaching extinction, and the assertions are rarely contradicted. These alarmists are generally unfamiliar with the subject, and they start with the assumption that little effort is made to protect moose from promiscuous slaughter, or take it for granted that such efforts are futile. Meanwhile increasing protection has been given the moose by laws regulating bag limits and hunting seasons, and by the establishment of game refuges in many quarters. These measures have already led to a considerable increase in the number of moose in many portions of his range.

Ex-Congressman Shiras, who has had exceptional opportunity to observe game conditions in many portions of the United States and Canada, expresses the opinion that the moose "is now more abundant and more widely distributed on this continent than at any previous period with which a comparison can be made." "When I first visited Lake Superior, in 1870," he writes, "moose were practically unknown on the southern or northern shores of this lake, and the same was true of a large area north of Lake Huron, for the larger portion of western Ontario was occupied only by the caribou. Now moose are present by thousands in the country north of these two great lakes, and to the western end of Ontario, and they are steadily increasing.

"This increase would have been impossible were it not that the food conditions have been improved ten-fold in the past fifty years by cutting down the pine, and by forest fires, followed by a second growth of poplar, cherry, birch, beech, maple, and mountain ash, besides ground vegetation. . . .

"Another remarkable increase of moose," says Mr. Shiras, 
"is found farther north, where they have taken possesssion of much of the wooded winter range of the barren-ground caribou. They have occupied the valley of the Mackenzie River, from its source to its mouth, besides new ground east and west of James Bay. In British Columbia, the Yukon, and much of Alaska there is also a steady increase in their numbers. ... "In New Brunswick moose had become extremely scarce prior to 1885 , and were limited to a few scattered individuals in remote districts, but the protection of the females, and the enforcement of other wise laws, have led to a remarkable improvement, and these animals have now spread over the entire Province."

Well-stocked game refuges of large area have been established in a number of the States and in most of the Canadian Provinces. Such of these as contain moose may be summarized as follows:

Yellowstone National Park Area, sq. miles

Glacier National Park, Montana

Mount McKinley National Park, Alaska Hoodoo State Game Preserve, Wyoming

Shoshone do.

do.

Carter Mountain do.

do.

Teton do.

do.

3,348

1,400

2,200

144

648

108

900

Superior State Game Refuge, Minnesota . . . . . 1,420

Quetico Provincial Reserve, Ontario .

3,900

870

640

Mount Robson National Park, do.

Waterton Lakes Park, do.

Jasper Park, do.

Twelve game refuges, Saskatchewan . . . . . 3,800

Thirteen

do.

Manitoba

5,000

Algonquin Provincial Park, Ontario

Laurentides Park, Quebec

Game preserve, Gaspé Peninsula, Quebec .

New Brunswick Game Refuge . 
In most of the game refuges here described moose are abundant; in all they are present under conditions favorable to a considerable increase. Hunting and trapping in these tracts are at all times forbidden. Some of the tracts are regularly patrolled by rangers at all seasons; others are patrolled only in the hunting season. In some the limits of the reserved areas have been plainly marked, as in the case of the Riding Mountain Preserve in Manitoba, where the timber and underbrush has been cut for a width of ten feet along the boundaries; in others the bounds are less plainly indicated, but in all cases game animals are free to enter and leave their sanctuaries at will.

The success of the efforts to propagate moose in Yellowstone National Park is related at page 38. Moose are found in all portions of the park. "One of our largest moose herds," writes the superintendent, "ranges in the marshes and meadows of the Bechler River and Falls River Basins, in the far southwestern corner of the park, and is thriving splendidly. Recent estimates place the number in the herd at slightly more than 500." (See page 51.)

Mount McKinley National Park, comprising 2200 square miles, was set aside by Congress in 1917 as a recreation ground and game refuge. In this area are "the principal breeding grounds of moose, caribou, and [mountain] sheep for all of the region between that part of the Alaskan range and the Tanana River," writes Governor Riggs of Alaska in his annual report. The park will be easy of access by means of the new Alaska Railroad. No provision has yet been made, however, for maintenance and patrol.

One of the largest and best-stocked wilderness sanctuaries for game in America, in which moose are found, is the Superior State Game Refuge in Minnesota, and adjoining it, on the Canadian side of the boundary, the Quetico Provincial Reserve in Ontario. The Superior Game Refuge was established in 1909. It is a State institution, the Superior National Forest, under Federal jurisdiction, being practically coterminous with 
it. This refuge comprises 1420 square miles, and United States forestry officials estimate that it contains at present 1500 moose.

Quetico Provincial Reserve in western Ontario comprises about 3900 square miles adjoining the Superior National Forest. The number of moose in the Quetico Reserve was estimated by Hugh McDonald, the superintendent, in October, 1919, at about 3500, and this, he says, is a conservative estimate based on the reports of rangers and others, as well as on personal observation. The two tracts thus aggregate 5300 square miles of contiguous territory, and the 5000 moose occupying the reserves enjoy at all times complete legal protection.

In addition to the Clearwater and Mount Robson game reserves in British Columbia, R. E. Hose, secretary of the Game Conservation Board, writes that two other game reserves are maintained in the southern part of the Province. In these, he says, there are few if any moose, "although all reports show that the moose are working south throughout this Province."

The late Dr. C. Gordon Hewitt, Consulting Zoologist of the Canadian Government, in a work devoted to "Conservation of the Wild Life of Canada," which will be published in 1920, states that it is the policy of the government of Quebec, on the borders of the parks which are most open to the inroads of poachers, to lease tracts of moderate size to individuals or clubs. These leases are for five-year periods, and under their terms the lessees are required to employ guardians, approved by the government, to insure adequate protection of the leased areas. By this means the game in the interior is effectively safeguarded. "Moose are plentiful in the Gaspésian reserve, as well as in the Laurentides Park," wrote Dr. Hewitt.

The latest addition to the list of game refuges is that established in New Brunswick in 1919. It comprises 400 square miles, or about eleven townships, and includes some of the best moose territory in the Province, at the head-waters of the 



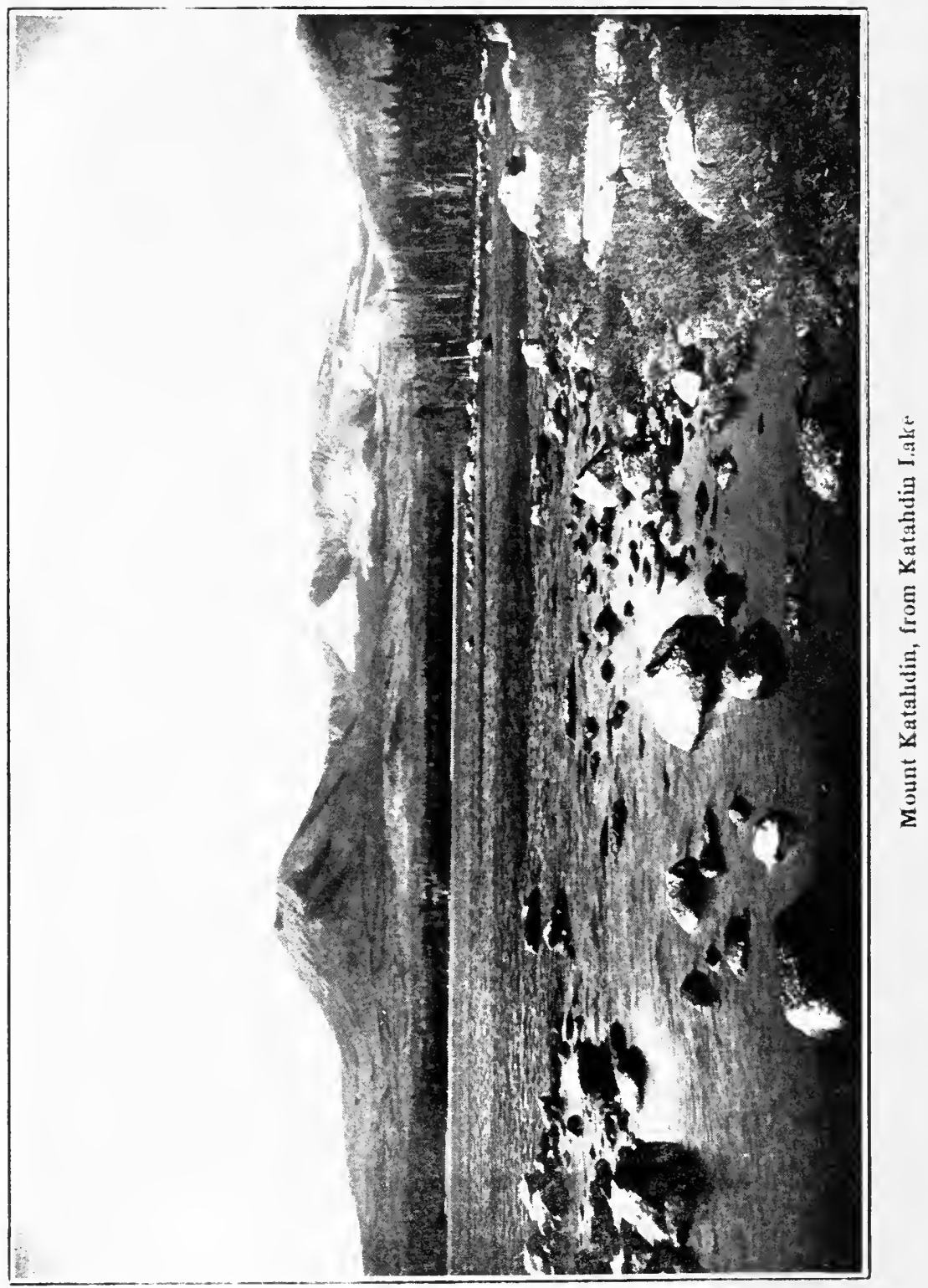


Nepisiguit, Little Southwest Miramichi, and the Serpentine branch of the Tobique Rivers.

The aggregate area of the public game refuges of the United States and Canada in which there are moose is already greater, by 7000 square miles, than the area of the States of Massachusetts, New Hampshire, Vermont, Connecticut, and Rhode Island combined. Most of the territory thus utilized is valuable for the production of timber, and the protection of water supplies, but is useless for agriculture, and the yield of timber will never be impaired by the animals and birds which find sanctuary there.

There is a constant tendency to increase the number and extent of the refuges where game animals and birds may breed undisturbed. For several years a plan has been under consideration at Washington to create a National park which shall include Katahdin Mountain in Maine, and the establishment of game refuges in the moose country of Nova Scotia has also been proposed. Such tracts, being under government control, and hunting being at all times forbidden, will effectively insure the maintenance, indefinitely, of a large stock of game. Moose are hardy and prolific, and the overflow from the many widely-scattered game refuges will serve to stock vast areas where hunting would be permitted.

\section{C.}

\section{MOOSE IN MICHIGAN}

(See page 36 )

Moose are increasing rapidly in numbers on Isle Royale in Lake Superior. The island, forty-seven miles in length, belongs to Michigan, but lies close to the Canadian side of the lake. It is frequented to some extent by summer visitors, but is un. inhabited in winter.

Dr. Charles C. Adams, professor of forest zoology in the New York College of Forestry, who spent two months at 
Isle Royale in 1904, writes that he saw no moose there at that time, and heard of none. In one instance, however, the party observed low maples which had been broken down, and the small branches eaten away, and this may have been the work of moose, although at the time it was attributed to 6aribou. But William P. F. Ferguson of Franklin, Penn., who has spent several weeks every summer at the island for a number of years past, writing recently to the game officials of Michigan said:

"As possibly you realize, you have there one of the finest moose preserves in the world. The island is admirably adapted for moose, and feed is plenty. The moose herd is rapidly increasing, and is producing some splendid examples.... Moose are now to be found in all parts of the island, though less numerous at the northeastern end, where the country is not so well adapted to them. From Washington Harbor up to Lake Desor and the Siskiwit country they are especially numerous. I was over that country very fully, and never saw any place where moose were more in evidence."

The game officials are arranging to station a deputy on the island, to remain the entire year, to protect moose and other game. No moose may legally be killed in Michigan at any time.

Mr. Ferguson tells the story of an amusing encounter which he had with a bull moose on the island. $\mathrm{He}$ was walking along a trail alone, carrying no weapon but a 45 -caliber revolver, when he met the moose, whose antlers spread some four feet. As the animal came nearer Mr. Ferguson shouted, but, with antlers lowered in a threatening manner, the moose continued to advance. Mr. Ferguson took shelter behind a big cedar, expecting the moose to continue on his way, but the animal turned from the trail, and came to still closer quarters.

"I thought I would have to kill him," he wrote, "but there flashed into my mind a case of a deer knocked out by a bullet 
that struck his antlers, so I took a shot at the broad leaf of one of his horns, not ten feet from me. I laughed till I cried at the result. The moose gathered his four feet under him like a broncho, and began a waltz. He went around about a dozen times; then he began to paw at his nose with his fore hoofs, standing, I think, on his hind legs, like a goat. After four or five minutes of that sort of thing he started down the trail. But he seemed to remember something, and turned, about five rods away, and started back. I concluded to try for the antlers once more, and when he was about three rods off I stepped out and fired again. I think I missed him that time, but the flash and noise seemed to make an impression, and he hit the trail back at top speed."

This encounter took place August 20, 1919. The conduct of the moose in seemingly looking for trouble was sufficiently unusual to be worthy of record.

\section{D.}

\section{NEW ZEALAND'S MOOSE EXPERIMENT}

THE moose's range, as it has existed from time immemorial, circles the earth, but it extends at no point so far south as the fortieth degree of north latitude. A few efforts have been made to extend this range, the most interesting of which is that to introduce moose in New Zealand, in the Southern Hemisphere. Writing of this experiment Capt. T. E. Donne, Secretary of the New Zealand High Commission in London, says :

"The first moose taken to New Zealand were secured from the Hudson's Bay Company in British Columbia. Fourteen youngsters were shipped from Vancouver in January, 1900. The steamer carrying them encountered a very severe storm, which lasted five or six days. The young moose were in crates in the fore part of the ship, and as she took an enormous quantity of water ten of them were either drowned or killed 
by the weight of the water, or died from exposure and want of food. Four of them, two bulls and two cows, had been placed under cover, and survived the voyage. I saw them on landing in Wellington, and they were then in perfect condition. These four were liberated [in Hokitika valley] on the west coast of the South Island of New Zealand. They remained in the vicinity of the place where they were liberated for some months, when two of the bulls and one cow wandered off into the heavy forest, and, so far as I can trace, have not since been seen. The remaining cow, which was very tame, remained alone near the settlement for twelve or fourteen years, when she probably died.

"In I909 I entered into correspondence with the Governor of Saskatchewan on behalf of the New Zealand Government, with a view of securing an additional consignment of moose. Through the courtesy of the Canadian Government permission was given for shipping moose to New Zealand. Mr. F. Moorehouse, a Government officer, was sent from New Zealand to Banff to make arrangements for conveyance of ten moose to New Zealand. When he reached Banff the temperature was $10^{\circ}$ below zero Fahr., and at $\mathrm{Fiji}$, about three weeks later, it was $90^{\circ}$ above zero in the shade. The moose had also passed through a severe storm, and had crossed the Equator and through the Tropics. They were taken to Sydney, Australia, and there transferred to another steamer, and conveyed 1200 miles to New Zealand. They were again transferred to a small steamer belonging to the Government, and taken to Dusky Sound on the southwest coast, where they were released in perfect condition, none having been lost on the journey. The locality where these ten moose were liberated is mountainous, with heavy forest, and is very rarely visited. As far as I know the moose have not since been seen. In any case there is no definite information as to their successful acclimatization or otherwise."

A Dominion official, writing from Wellington, N. Z., November 24, 1919, states that the second consignment of 
moose-four young bulls and six young cows-were liberated in the Fiordland National Park early in 1910. "Arrangements are being made," he writes, "for the Government Conservator of Fish and Game to visit the locality during the ensuing summer with a view to ascertaining the present condition of the herd."

There would seem to be little occasion to apprehend that these moose have succumbed after reaching their new forest range. Having survived in good condition a railway journey of several hundred miles, followed by ocean voyages across tropical seas a distance equal in the aggregate to more than a third of the circumference of the earth, it is not at all likely that they have all perished sine prole, as the genealogists say.

Capt. Donne writes that a large consignment of wapiti and Virginia and blacktail deer, together with a mixed assortment of American geese and ducks, were sent from the United States to New Zealand in 1905, and that these have become fully acclimatized and are thriving in their new environment. The moose released in Newfoundland some years ago were supposed for a long time to have perished, but they were living contentedly in retirement all the while, and increasing constantly in numbers. Dusky Sound is near the southern extremity of the South Island of New Zealand, about as far from the Equator as Nova Scotia and southern New Brunswick, and the Canadian moose released there will probably in due season give a good account of themselves. The fact that one moose lived for twelve or fourteen years in that region is evidence that differences in climate and vegetation will offer no obstacles to the success of the experiment. 
E.

\section{STOCKING NEWFOUNDLAND WITH MOOSE}

IT is supposed that Newfoundland became separated from the North American mainland at the Straits of Belle Isle in an early geologic age, before the arrival of the moose on the Atlantic seaboard. At any rate, the earliest white settlers found on the island no trace of the great deer which was so important a factor in the lives of the mainland Indians.

The late James P. Howley, F. G. S., director of the Colonial Geological Survey, wrote that in the late ' 7 os of the last century two young moose were obtained from Nova Scotia, and released at Gander Bay, in eastern Newfoundland. In 1912 a bull, five or six years of age, supposed to be a descendant from this pair, was killed on the Gander River. The man who shot the moose asserted that he fired in selfdefense. The head was mounted, and is now in the office of the Game and Inland Fisheries Board at St. John's. The antlers have $7+7$ well defined points, but the spread is only $33^{\mathrm{I} / 2}$ inches. The greatest breadth of palmation is 8 inches right, $73 / 4$ inches left; circumference of beam, $5 \frac{1 / 2}{2}$ inches. A smaller bull, still carrying his antlers, was found dead on the banks of the Gander, near Glenwood, in April, 1919. The cause of his death is unknown. These antlers have $5+5$ points, spread $3 \mathrm{I}^{\mathrm{T} / 2}$ inches, and the palmation measures $43 / 4$ inches right, and $4 \frac{1}{2}$ inches left.

In the early summer of 1904 , through the agency of Mr. Howley, two bulls and two cows were brought from New Brunswick, and released near Grand Lake, in western Newfoundland. Their progeny are now found in increasing numbers around Deer Lake, Grand Lake, the upper Humber, and in the country about Serpentine River. The success of the experiment in stocking the island with moose thus seems assured. There is no open season for hunting moose in Newfoundland. 
J. R. Whitaker, an Englishman living at Curling, in western Newfoundland, writing under date of September 24, 1919, said: "A few days ago I saw two good bulls feeding in a pond. They allowed me to get within forty feet, and even then, although I shouted and threw some gravel, they, far from being inclined to retire, as I expected them to do, showed a warlike front, and as the water was very shallow I beat a retreat in my canoe. They had each thirteen points. Two da:s later I saw another bull with a very good head. . . . Five or six moose have yarded near my place for the winter on three occasions." Mr. Whitaker expresses apprehension that the Newfoundland moose stock may deteriorate by reason of inbreeding, unless new blood is introduced from the mainland.

F.

\section{THE OLYMPIC NATIONAL FOREST}

THE only attempt yet made in the United States to restock any portion of the moose's ancient range was in the Adiron'dacks in 1902, and this modest effort was wholly unsuccessful. (See page 34.) A plan is now under consideration, however, to secure moose from the Kenai Peninsula in Alaska, and release them in the Olympic National Forest in northwestern Washington. This is a heavily timbered and mountainous region of about 2500 square miles, the culminating feature of which is Mount Olympus, 8150 feet in height.

The Olympic Peninsula is almost uninhabited, having few trails and fewer roads, and it is not adapted for agriculture. All the conditions seem favorable for moose. Wapiti, to the number of more than 3000 , are found on the peninsula, according to the United States Forester, but moose and wapiti have complete protection in the State until 1925. United States Forest Service officials and the Bureau of Biological Survey at Washington have interested themselves in this undertaking. They planned to secure moose for this purpose in the winter of 1919-20, but conditions in the Kenai country 
with respect to snow prevented. The effort will be renewed in the winter of $1920-2 \mathrm{I}$.

Another attempt to extend the range of the moose is being made in South Dakota. The State authorities have arranged to exchange South Dakota buffalo for Wyoming moose. Under this plan four moose from the Jackson Hole country will be released in the State Game Park of 100 square miles in the Black Hills, in the southwestern portion of South Dakota. An unsuccessful effort to carry out this plan was made in the winter of 1919-20. The effort will be repeated next winter.

\section{G.}

\section{MOOSE IN PENNSYLVANIA}

IN his Mammals of Pennsylvania and New Jersey (Philadelphia, I903, pp. 224, 240), Samuel N. Rhoads states that fossil remains of the "East American moose" have been found in Durham cave, near Riegelsville, Bucks County, southeastern Pennsylvania.

In historic times moose are said to have been found in northeastern Pennsylvania. Hollister, in his History of the Lackawanna Valley (Philadelphia, 1885, p. 32), says that in the vicinity of Capoose, an Indian village near the site of Scranton, in the later years of the eighteenth century, "the moose and elk stood among the pines or thundered through them like the tread of cavalry." But the people of Pennsylvania often gave the name "gray moose" to the wapiti, and references to the moose by early writers in that State are therefore to be accepted with caution.

Moose Creek in Clearfield County, western Pennsylrania, is said to have taken its name from Chinklacamoose, an Indian village which stood on the site of Clearfield. Henry Gannett ("Origin of Certain Place Names in the United States," in Geological Survey Bulletin No. 258, page 214), interprets this word as meaning "it almost joins," referring to a horseshoe bend formed by the stream. Another authority suggests that 
Chinklacamoose may be derived from certain words meaning "large laughing moose," probably the name of a chief (Handbook of American Indians, vol. i, p. 272), but this would carry with it no implication that moose had ever occupied that region.

A number of Pennsylvania legends in which the moose figures are related by Henry W. Shoemaker in Pennsylvania Deer and Their Horns (Reading, Pa., 1915), and in Juniata Memories (Philadelphia, 1916), by the same author. Mr. Shoemaker states that among the place names of Pennsylvania are found Moosic Lake in Lackawanna County, Moosic Mountain in the same vicinity, and, in Clearfield County, two Moose Creeks. Moosic village is six miles south of Scranton.

"Moosic" in Pennsylvania and "Moosup" in Connecticut naturally suggest the presence of the moose at some time in those sections. But, according to J. Hammond Trumbull, "Moosup River .... was formerly Moosup's River, Moosup or Maussup being one of the aliases of a Narragansett sachem who is better known, in the history of Philip's war, as Pessacus." (Collections, Conn. Hist. Soc., vol. ii. [1870], p. 37.) And Dr. Hollister may easily be mistaken when he says that Moosic Mountain "takes its name from the moose inhabiting it at the time of the earliest exploration by the whites."

\section{H.}

\section{VERMONT'S LAST MOOSE}

(See page 33.)

ONE day in March, 1899, a report was brought to a lumber camp near Island Pond, Essex County, Vermont, that a strange animal had been seen in the woods not far away. Two men started in pursuit, and one of them, Jake Barnes, killed the animal by a shot behind the ear. It proved to be a young bull moose. The killing was contrary to law, and in the following September the case was brought before the grand 
jury. The evidence against Barnes was conclusive, and he admitted his guilt, but no bill was found against him. The

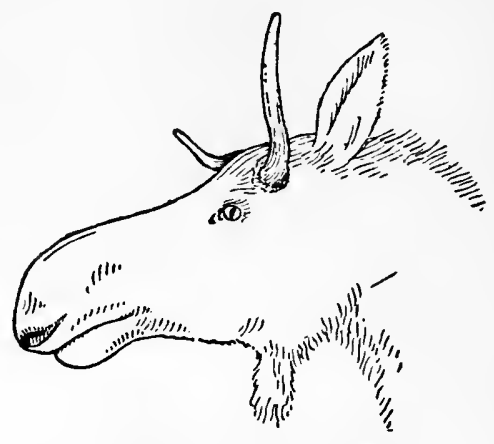

Vermont's Last Moose

head of the moose-a spikehorn-was mounted, and is preserved at the University of Vermont.

This was the last moose killed in the State. It was probably a lone wanderer from Quebec or New Hampshire. (See I5th Biennial Report of the Vermont Commissioners of Fisheries and Game, p. 83.)

\section{I.}

\section{PARASITIC ENEMIES OF THE MOOSE}

(See pages 73, 306.)

A Loss of moose in Saskatchewan in 1915 through the attacks of parasites is mentioned in the report of the Chief Game Guardian for 1916. Similar losses were reported from the Riding Mountains in Manitoba.

The late Dr. C. Gordon Hewitt, Dominion Entomologist, identified this parasite, which is variously called "moose tick," "elk tick," and "wood tick," as Dermacentor albipictus. The pest is widely distributed over the Dominion of Canada and the northern United States, he said, and attacks horses and 
cattle as wcll as game animals. Dr. Hewitt gave preference to the name "winter tick" for this species, the name referring to its habit of infesting its victim in the winter and spring months. Moose often find relief from insect pests in summer by taking refuge in the water, or by wallowing in mud holes, but the lakes are covered with ice, and the muskegs frozen, in the season when the winter tick is active.

One of the district game guardians of Saskatchewan described the ravages of this parasite in his report as follows: "Last spring many of the moose were literally eaten up by a parasite spoken of as the 'wood tick.' This parasite has a small head, which it buries in the skin of the moose, and then sucks the blood, until its body becomes distended to about the size of a large bean. They appear to cause such an itching that the animal can neither rest nor feed, and in their efforts to get rid of the pest will rub against trees until much of the skin is rubbed off, and they gradually become so weak that they lie down and die. In some localities it was estimated that fifty per cent of the moose had thus been killed off."

Probably the loss of moose from this cause was much less than this report would lead one to infer. Dr. Hewitt, in a letter from Ottawa dated August 15, 1919, stated that since 1916 he had received no records of moose being seriously infested by ticks, and the matter is not referred to in the later reports of the Chief Game Guardians of Saskatchewan and Manitoba.

A newspaper report, widely circulated in 1919 , to the effect that "inñuenza is decimating big game" in northern Saskatchewan, and that "investigation has disclosed diseased lungs among moose, that become exhausted quickly when pursued," is contradicted by the game officials of the Province. "Our investigations," they say, "have failed to reveal any facts that would substantiate this report." 


\section{J. \\ NEW BRUNSWICK'S HARNESSED MOOSE}

(See page 75.)

REFERENCE is made in the chapter on Traits and Habits of the Moose to a story which is current in New Brunswick, that years ago a moose was driven in harness from Fredericton to St. John and return in a single day. My own efforts, by correspondence and otherwise, to obtain more circumstantial details of this occurrence were fruitless. I was informed that the owner of the moose had been a former Governor of the Province, but could learn nothing more. Professor William F. Ganong, a well-known writer on subjects relating to the history of New Brunswick, and its natural history, for whose friendly interest in the Moose Book since it was first published I am under great obligation, has convinced me that this story of the harnessed moose should be given a place among the myths with which the moose has from time immemorial been surrounded.

Professor Ganong writes that Governor Sir Edmund Head, who lived in New Brunswick from 1848 to 1854 , owned a moose which was often driven in harness, and this moose took part in races on the ice at Fredericton against horses belonging to army officers. Lord Hill, an officer who was stationed in Fredericton more than twenty years before Governor Head's time, was also fond of racing, but it does not appear that moose occupied any place in his stable. A contemporary account may be found in the files of the St. John Gazette of a race which took place January I, I825, in which a pair of horses belonging to Lord Hill were matched against another pair to race from St. John to Fredericton on the ice. Lord Hill made the eighty-seven miles in six hours and thirty-two minutes, winning the stakes. Thus far, Professor Ganong writes, the statements appear to be warranted by the facts. 
But the accounts of Governor Head's moose and Lord Hill's horses seem to have become blended later in a single story, one version of which is found in a newspaper clipping dated in 1891. The writer of the paragraph in question told how Governor Head's tame moose was matched to race on the ice from Fredericton to St. John against "any team of horses in the stud of Lord Hill of the 52d Regiment." The moose, according to this story, covered eighty-four miles in seven hours, and won the purse. In this account, as in that printed in 1825 , one horse in the losing team died of exhaustion before completing the prescribed distance. Such details were added later to this story as the imagination of narrators could supply, the moose himself, in the final version, losing his life at the end of his day's work.

Professor Ganong is doubtless justified in his conclusion that the account of the moose's long journey on the ice is without basis of fact, the story being a distorted survival of the account of the race in which Lord Hill's horses took part in 1825 .

\section{K.}

\section{AREA REQUIRED FOR MAINTENANCE OF MOOSE}

(See page 87.)

Henry J. Elwes, F. R. S., the English sportsman and naturalist, leased hunting privileges on many farms in Norway, aggregating thousands of acres of the best elk country, and hunted there through September in six different years. A valuable paper on "The Habits and Present Condition of the Elk in Norway," written by him, is published in the Proceedings of the Zoological Society, 1903, vol. i., pp. 133-151. In this paper, at page 138 , he discusses the amount of feedingground required to maintain elk, or moose.

"From its great size and the nature of its food," he writes, "the elk requires a much larger extent of feeding-ground than 
any animal I am acquainted with, except the elephant; and I should suppose that at least three square miles of suitable forest would not support more than one elk continuously, judging from the number I have found in places where they were at home and undisturbed."

Official estimates indicate that 5000 moose are now living on an area of 5300 square miles in northern Minnesota and western Ontario (see pages 363-4). It is not stated that these moose exhaust the available forage. These facts tend to show that Mr. Elwes may be in error when he estimates that three square miles of forest are required for the support of each elk (or moose). Woodsmen whom I have questioned consider three square miles ample permanent feeding-ground for several moose. Of course much would depend on the character of the timber and undergrowth. Suitable feed is probably less abundant in the woods of Norway, where Mr. Elwes hunted, than in the Superior and Quetico game reserves, fifteen or sixteen degrees farther south.

Writing of moose in Manitoba Ernest Thompson Seton describes an area of about 500 square miles where "there is a moose population of a round 1000 , or two to the square mile. This is what most hunters consider fairly good moose country, although a rate ten times as high is found in some localities." (Life Histories of Northern Animals [New York, 1909], vol. i., p. 155.) If moose are present in any given area in such numbers as even five or ten to the square mile, however, it will be found, after a very few years, that some classes of forage have become scarce, and then the animals will seek new feeding grounds. Such fluctuations in the numbers present in certain sections have been observed many times. The moose, unlike the caribou, is not naturally a migratory animal, but he is always ready to safeguard his future by a change of scene.

The estimate of Hon. George Shiras, 3d, with regard to the number of moose in a limited area on the upper Yellowstone is quoted at page 38 , and at page 284 facts are given which tend to show that certain East Prussian forests, before 
the recent war, contained many elk to each square mile. It is to be presumed, however, that the elk of East Prussia were regularly given other food than that which the woods naturally supplied.

L.

\section{JACKING BY AUTOMOBILE HEADLIGHT}

(See page 145 .)

USE of the automobile has introduced a variation in jacking which is thus referred to in the Report of the Commissioners of Inland Fisheries and Game for the State of Maine, for 1916, page 2I:

"Good automobile roads extend for miles through the heart of our big game country, and, as it has become known how readily deer and moose may be held at a stand by the highpower searchlights with which the modern car is equipped, and thus become an easy prey to the night hunter, the popularity of this 'sport' is increasing. . . . Such hunters are even more despicable as a class than their brethren of a generation ago who made a practice of jacking deer on the lakes and ponds during the summer months. . . Stock has been killed in the pastures, and in one law-abiding community this season a horse was shot down in the highway, the lights of the jack, although showing up the 'gleam' and the two ears of the 'moose,' not clearly revealing the presence of two unoffending occupants of the carriage.

"Unfortunately, even in the daytime, game of all kinds appears to have very little fear of a moving automobile, while in the night it is attracted by the headlights, and makes no effort to escape.... In the face of these conditions legislation prohibiting the shooting of any wild animal or wild bird from an automobile is worthy of consideration. Such a law might perhaps lessen the practice of night hunting, although 
hard to enforce, as are all restrictive laws where the violator has the advantage of a quick get-away."

A statute enacted by the Maine Legislature in 1919 makes it a penal offense to have a rifle or shotgun, either loaded or with a cartridge in the magazine, while in any motor vehicle on any highway or in the fields or forests; and the Legislature of Minnesota in the same year passed an act forbidding anyone in a motor vehicle discharging a firearm at any game animal, and also forbidding carrying a rifle or shotgun in such vehicle "unless the same be unloaded, in both barrels and magazine, and taken apart or contained in a case."

M.

\section{THE SPRINGFIELD RIFLE IN BIG-GAME HUNTING}

(See page 156.)

MaNy young men who served in the recent war are considering the Springfield rifle, and the United States Government cartridge, for use in hunting. Being much too old to engage in the pursuit of a military antagonist $I$ gave this weapon a trial when moose-hunting in 1917. My bullets weighed 180 grains, being of the full-jacketed "spitzer" type, and they were driven with an initial velocity of about 2700 feet a second.

One November morning, while following some promising tracks on a hard-wood ridge in New Brunswick, I saw a goodlooking bull seeking safety in flight, some eighty yards away. The Springfield went promptly into action, and then I ran forward. In a few seconds I came upon the moose standing, and looking back with dull eyes. It was evidently impossible for him to travel further. He soon lay down: he needed no second shot... . The bullet had entered between two ribs, then evidently turned end over end, and, after doing great internal execution, passed between two ribs on the other side, 
lodging in the flesh of the shoulder. It struck no bone, and to-day shows practically no scar, save the marks of the rifling. The same bullet, if driven with much less velocity, would not do the work.

Three bullets from the same box of twenty cartridges secured for me the bag-limit of big game in New Brunswick in 1919-two deer and a moose. My moose yielded to a blow high in the shoulder. The bullet broke one of the long dorsal processes above the spinal column, without visibly affecting
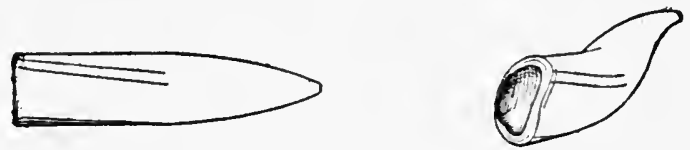

Bullets which have Killed Moose

the spinal cord, and lodged under the skin on the farther side of the animal. The shock must have been tremendous, for the moose had no power of locomotion left, and died without requiring further punishment. The bullet was blunted slightly at the point, and flattened a little at the base, and it was twisted into a sort of corkscrew shape, conforming to the curve of the rifling.

Other experienced moose-hunters have found this load equally satisfactory: The ordinary Springfield cartridge, with $150-$ grain bullet, is nearly as effective as the special load using the heavier charge of lead.

\section{N. \\ MOUNTAIN ASH IN ANTLER-BUILDING}

(See page 174.)

Mr. Elwes, whose paper on the elk of Norway is quoted at page 377, hunted in the Norwegian Provinces of North and South Trondhjem (or Drontheim), where, as he wrote (p. 133), "the elk is more numerous than perhaps in any 
other part of Europe, and where it seems to attain a greater size and vigor, if one may judge by the development of the horns, than anywhere else in Scandinavia." Discussing the relative size of elk antlers from different sections of Scandinavia, Mr. Elwes said (p. 149): "In North Trondhjemsamt, where the elk a few years ago was extremely numerous, much larger heads occurred, owing, I believe, to the much greater quantity of mountain ash, which seems to be the favorite winter food of the elk."

When asked recently for his views on the subject of the causes which will influence, favorably or otherwise, antlerdevelopment in moose, Mr. Elwes wrote: "Over-stocking, whether of elk, red deer, or wapiti, is most prejudicial to the development of the horns. . . . I do not think that climatic conditions are so important as abundance of suitable food." Referring to the estimate that 5000 moose are now to be found in the Superior and Quetico game refuges (see pages 363,364 ), or nearly one moose to each square mile, Mr. Elwes writes: "I can hardly doubt that, unless the old cows, and bulls with inferior horns, are systematically killed by approved hunters, the same deterioration of horns will occur in a comparatively few years which has taken place among the red deer in certain parts of New Zealand."

A pair of antlers spreading 54 inches, taken in Trondhjem in about $64^{\circ}$ north latitude, and having $9+9$ points, is "the widest, though not the largest, I have seen from Scandinavia," wrote Mr. Elwes.

If the large elk antlers of North Trondhjem are to be associated with the abundance of mountain ash, one will naturally query whether mountain ash is also the secret of the great development of moose antlers on the Kenai Peninsula. Writing of the seasonal food of the moose and beaver, Hon. George Shiras, 3d, remarks that both are bark eaters in winter and almost wholly dependent on aquatic plants and other perishable vegetation in summer. This provision of nature tends to conserve arboreal growth. 
"Both the moose and beaver are fond of mountain ash," he writes, "though both prefer poplar, which, by the way, is the main winter food of the moose on the Kenai. This district has been largely burned over, with a resultant second growth that is very favorable for the moose. I would attribute the size and massiveness of the antlers on the Kenai, however, largely to favorable climatic conditions. The Peninsula is practically an island, with an equable climate, winter and summer, thus favoring the moose physically, and insuring a variety and seasonal uniformity in vegetable growth. Unlike the islands, however, which are drenched with rain in the summer, and smothered with snow in the winter, the Kenai has only a fair amount of rain and a light snowfall. In the interior range of the moose, on the mainland, there is much aridity and very severe winters, adversely affecting the moose directly, and rendering uncertain the food supply."

Professor William F. Ganong questions the importance of the food factor in antler-building. "If the underlying idea of the relation of size of moose antlers to food," he writes, "is that certain kinds of food stimulate the production of larger antlers, or that the antlers grow bigger because of the accumulation of good food, I do not think the idea is correct physiologically. I think the size of antlers, like the size of the animal, is a specific character, fixed in heredity. Deficient food can dwarf the antlers, as it can dwarf the animal: sufficient food can permit the antlers to reach the full specific size, but extraabundant food cannot make them any larger, unless it acts in some way as a chemical or physical stimulus, of which we have no evidence. This is the way it seems to me, but other biologists might see it differently, so perhaps it is not worth while to argue the fine point."

This subject, and that of the "carrying capacity" of forests for moose-the number of animals which can subsist on a tract of a given size-will perhaps be subjects of study at the Roosevelt Wild-Life Forest Experiment Station, which has lately been established in connection with the New York State 
College of Forestry. Neither topic seems to have received adequate attention at the hands of zoologists.

O.

\section{EUROPEAN ELK IN WAR-TIME}

(See pages 284,291 .)

IT would be interesting to know to what extent the elk of Europe contributed to relieve the food shortage incident to the recent war, and how far the elk have suffered from the removal of legal restraint in Bolshevik Russia, and in East Prussia. Little information relating to these subjects has, however, been received in this country.

The kill of elk in Sweden in 1913, the last year preceding the war, was 2043. In 1914 the number fell to 1769 , but, as Prof. Einar Lönnberg of Stockholm writes me, the number increased in the four following years, according to official reports, to 2765, 2691, 25II, and 2369, respectively. Prof. Lönnberg expresses the belief that the number killed in 1919 will be found to be much smaller, owing to depredations by poachers. Large numbers of elk were illegally killed during the years when Swedish imports were reduced by reason of the maritime blockade, and their loss is likely to affect the kill for some years to come. (Dr. Lönnberg is the author of a valuable paper on "The Variation of the Elk," which was published in the Proceedings of the Zoological Society of London, 1902, vol. ii., pp. 352-360.)

In Norway the average number of elk killed yearly in the four years prior to 1915 was 1297 . In 1915 and the three following years the numbers were 939, 1170, 1246, and 1040, respectively. Peter Norbye, a sportsman of Selbu, in the Province of Trondhjem, who kindly furnished me these facts, writes that elk hunting in Norway will probably be subjected to increased restrictions for a number of years, on account of depletion of the stock. Throughout Scandinavia poachers were 
active during the war, and the game which they killed does not generally appear in the official statistics.

There is no reason to doubt that the elk in Russia, Finland, and East Prussia have suffered much more in the past few years at the hands of hungry peasants than have those in Scandinavia. Martenson, a Russian, wrote in 1903 that in his country more than 200,000 elk were killed yearly. (Der Elch, pages v., 166.) At that time elk hunting was closely regulated by law. It is to be apprehended that under Bolshevik administration the kill of elk in that country has very greatly increased, just as the number killed in East Prussia increased during the Revolution of 1848 . (See page 284.) And of course food shortage and political confusion have created a somewhat similar situation in other regions bordering on the Baltic.

$$
\text { P. }
$$

\section{FOSSIL ELK IN ENGLAND}

(See page 337.)

Edwin Tulley Newton, F. R. S., F. G. S., in a paper read, December I7, 1902, before the Geological Society of London,

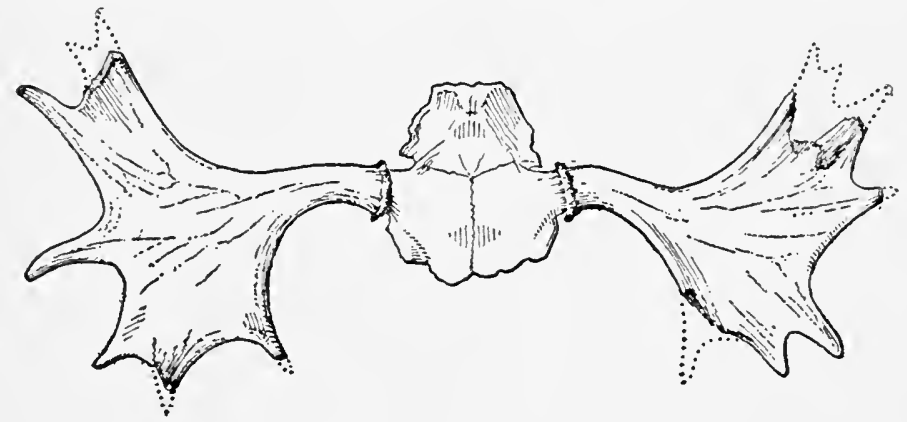

Fossil Antlers Found in England

describes and illustrates fossil antlers of elk discovered in the Thames valley, twenty miles west of London, three or four 
years earlier. They were found seven feet below the surface, in somewhat peaty soil. The antlers are imperfect. They had about $7+7$ prongs, spread 39 or 40 inches, and were broadly palmate. (See Quarterly Journal, Geol. Soc., vol. lix. [1903], p. 8o.) According to Newton, fossil remains of elk found in England date from a period subsequent to the Pleistocene. John Alexander Smith (Proc. Soc. Antiq. Scot., vol. ix. [1872], p. 297) mentions more than twenty localities where elk remains have been found in the British Isles, chiefly in southern Scotland and northern England.

The fossil antlers here illustrated, although peculiar in shape, are not especially characteristic of a prehistoric type. In his Life Histories of Northern Animals (vol. i., p. 156), Ernest Thompson Seton pictures the antlers of a three-year-old moose, killed at Lake Winnipeg in 1904, which very closely resemble these fossil antlers which had lain for thousands of years in the valley of the Thames. 


\section{INDEX}

In cases where page references are separated by a double colon, the references before the double colon refer to the American moose; those following it refer to the Old-World elk (or moose)

Abnaki, name of moose, 237; Rasle's dictionary, 237 (note), $265,267,268 ;$ myths, 247

Accessories for hunting trip, 163165

Adams, Dr. C. C., quoted, 365

Adirondacks, moose in, 33-34, 371

Adney, Tappan, quoted, 98 (note)

Age which moose attain, 73, 173:: 301-302; difficulty of estimating age, I 7 I

Aim, point at which to, 160

Akeley, C. E., on taxidermy, 197

Alaska, 53, 56, I18, I21, 316; moose in, 39 (note), 4I; number of moose, 43-44; increase in number, $42-44,362$; game law, 44, 52; Alces gigas, 59-60; brow palmation of antlers, $6 \mathrm{I}$; gain of territory by moose, 39 , 42 ; importance of big game, 221 (note); size of moose, $60,64,67$; Mount McKinley National Park, 362, 363. See Kenai Peninsula

Alberta. 39, 54, 55; game law, 52 ; number of inoose killed, 45; antlers, 183, 358; big-game refuges, 362

Alce alces, 62

Alces, origin of name, 239-240

Alces americanus, 56, 59, 62

Alces americanus shirasi, 60 (note)

Alces bedfordice, $343^{-} 345$

Alces gigas, 59-60, 62

Alces latifrons, 335

Alces machlis, 62, 241-242

Alces palmatus, 62

Aldrovandus, elk portraits, 278279

Alger, Miss A. I., an Indian myth, 25I-254
Algonquian names of moose, 237

Algonquin moose myths, 247-254; the epilepsy superstition, 266

Algonquin Provincial Park, Ont., 362

American Museum of Natural History, 197, 244

Ammunition, I52-160, 380-381

Ancient hunting methods, 132 et seq.

"Animal magnum," 242

Anthrax, $73:: 305$

Antlers of moose-Alaska, 177I 80; Alberta, I83, 358; British Columbia, 182, 357; Maine, I86, 189; Manitoba, I83; Minnesota, 184; New Brunswick, 187-189, 359-360; Nova Scotia, I89, 360; Ontario, I 84-1 86; Quebec, I 86, 358; Saskatchewan, 358; Y ukon, I 80-182

Antler characteristics inherited, 360 ; blunt points, cause, 360 ; brow palmation in Alaska, 6r; cast antlers found in woods, 171, 182; causes which affect growth, 174, 360, 382-383; color, how restored, 200; of cow moose, 174-175; deterioration, I69-I 70, 360; earliest American specimens, 166-I69; effect of bullet striking, 366-367; effect of food on growth, 38I383 ; exaggeration regarding, 21 , 26,176 ; used in fighting, 81, 172, 173; growth of, 170-174, 360 ; Indian uses for, 202 ; interlocked antlers, 175; measurement, 190-194; mounting heads, 194-198; in old age, 173, 360; spread not the only test, I93; time of casting, I7I; velvet, 
172 ; weight, 176, 178, 180, 181 (note), 191, 358; mounted on wooden heads, I67. See Elk Arctic Circle, 39, I80 :: 288

Area required by moose, $377-378$

Arms and ammunition, I52-I60, $380-381$

Arseneau, Joseph, moose antlers, 359

Articles made from moose products, 202-203 :: 284-287

Asia, earliest home of moose, 3; elk range in, 288-289

Attacks by moose on men, 76-8I, 366-367; when jacking, 1 46-1 47

Audubon and Bachman, marrow as food, 2 I I t the muffle, 2 I 4

Automatic rilles, I 52, I 59

Automobile, use of in hunting, 380 ; headlight as a jack, 379

Baird, Prof. S. F., quoted, 7475

Baltic provinces of Russia, 290, 292, 3 I 6, 322, 385

Banff, moose antlers, 358; moose shipped to New Zealand, 368

Barren-ground caribou, 362

Barren Lands, moose in, 48

Basques, their name for moose, 238

"Battle Between Bulls," 8 I

Beam, circumference, how measured, I9I

Beaver's tail as food, 212-2I3

"Before the Battle," I 30

Bell of the moose, 68 ; of old moose, illustrated, 174

Bell, J. M., an Indian myth, 257260

Bell, Dr. Robert, moose killed for skins, 30; migration of moose, 39-40

Berkshire Hills, moose in, 35

Bierstadt, A., moose antlers, I 89

Black Hills, moose to be released in, 372

Blacktail deer, 369

Blasius, Prof. IW., 285, 287, 309; age of elk, 30I; diseases of elk, 305

Blowflies, I 63

Blue Mountain preserve, 36

Blunt points in antlers, cause, 360

Bock, S. F., epilepsy in elk, 347
Bolt rifles, I 57, 380-38r

Bone in the moose's heart, 267$268:: 35$ I

Boston, moose killed near, 24, 35

Boucher, P., the epilepsy superstition, 265-266

Bows and arrows, compared with firearms, Io

Brandt, J. F., fossil elk antlers, $336-337$

Breck, Dr. E., on calling, 129 (note)

Breeding moose in captivity, $7 \mathbf{I}-73$

Brehm, A. E., 225; elk in captivity, 3 I5

Bright colors for hunting clothing, 90, I6I

British Columbia, 55, I30; moose in, 39; game law, 52; hunting in, 45; antlers, I 82, 357; biggame refuges, 362,364 ; increase in number of moose, 362,364 ; moose taken to New Zealand, 367

"Brought to Bay," 32 I

Brow palmation of Alaska antlers, 6I

Browne, Belmore, an episode in Alaska, i I 8

Browsing and peeling, 107

Buffalo, South Dakota, exchanged for moose, 372

Buff-leather, I 5,28

Buffon, 62, 282

Bujack, J. G., 354; epilepsy superstition in America, $35^{\circ}$

Bull's response to call, 124

Bullets which have killed moose, 381. See Firearms

Burnt land favorable for moose, $36 \mathrm{I}, 383$

Burrard, Sir Harry, moose antlers, I 88

Cæsar, 240; describes the elk, 274

Calf moose, 71 ; birth, 83-84; rapid growth, $84-85$; show little fear of men, $85:$ protected, 52

Calling, I20-I31 :: 327-330; the season, I20; in Alaska and $\mathrm{Yu}$ kon, I2 I; the calling stand, I22; the call, I24; the bull's answer, I24; contests between bulls, 125 : 328-329; freedom from 
wind important, 125; "speaking bull," I26, I30 :: 327; calling from a canoe, 127 ; diversity in calls, 127; value of moonlight, 128; early morning calling, 128; the calling horn, 128; in Russia, 327-329; by violin, 329

Canaan River, N. B., I 88

Canada, 30, 124 (note), 137, 238, 260,338 . See the several Provinces

Canada jays, 306

Canadian Northwest, gain of territory by moose, 39, 362. See Northwest Territories

Canoes made of moose skins, 140

Cape Breton, 27, 145

Captivity, moose in, 17, 71-75, 376-377::307-315

Cariacus virginianus, see Virginia deer

Caribou, 27, 46, 75, 155, 175, 194 , $201,224,230,362,36.3,366$; in Ontario, 36I; migration from Asia, 4

"Carrying capacity" of forests for moose, $377-378$

Carter Mountain State Game Preserve, Wyoming, 362

Cartier, Jacques, explorations, 5

Cassiar District, B. C., 45, I82, 357

Cast antlers found in the woods, 171, I82; time of casting, I 7 I:: $341-34^{2}$

Caswell, Col. J., moose antlers, I $86,358-359$

Caton, I60; moose and Scandinavian elk identical, 57, 243

Catskills, moose in, 35

Caughnawana Club preserve, I 86

Cerous alces, 62, 239-240, $27 \mathrm{I}$ (note)

Cervus canadensis, see Wapiti

Cervus elaphus, see Red deer

Champlain, 25; Indian moose hunting, 6; Indian banquet, 9; Indian moose drives, I 35

Changes in the moose range, 32 , $39,361-364$

Chapman, A., 320; stalking elk, 3 I $7-318$

Charlevoix, 262; slaughter of moose, 28; Indian moose drives,
134-135; the giant moose, 26026I; the epilepsy superstition, 265, 266

Chinklacamoose, 372

Chops, how to cut, 209

Cincinnati, moose in captivity, 7. $1-72$

"Circling" for elk, 325

Clearwater Game Reserve, B. C., 362

Climate, influence on antler development, $382-383$

Clinch, D. W., on calling, I 29 (note)

Clothing of moose skin, 6, 17 (note), 28, $202:: 284,285$

Clothing for hunting, I 61,163

Clothing, white, for hunters, 47

Cold storage of moose meat, 206207

Color-blindness of animals, seeming, 90

Color of antlers, how restored, 200

Color for hunting clothing, 47, I6I

Color of moose, 68, I 73

Colosseum at Rome, elk in, 275

Commerical importance of venison supply, 222-223, 225-226

Connecticut, place names, 373

Conservation of timber and game, 222-223, 36I-365

Cook, F. H., moose antlers, 187

Cooking, see Food

Corbin, Austin, moose in preserve, 36

Corned moose meat, 2 I 8

Courland, 292, 306

Cow moose, defence of calf, 85 :: 303; protection of, 52, 228-229 $:: 296$; how tracks are distinguished, I10; the call, I24; cow with antlers, I74-1 $75:: 175$ (note)

Cracking of moose scalp, cause, 194

Cree Indians, 135, 237

Crust hunting, by Indians, 6,8 , 137-I4I; in Maine, I4I, 227; in Russia, 33I

Cuvier, 62

Dahms, Dr. P., 285, 287, 348; size of elk, 282; elk hoofs in medicine, 349 
Danger from moose in captivity, 71 ; in the woods, $76-81,366-$ 367

Darrow, W. Jr., Quebec moose antlers, 358

d'Aulnay, Sieur, trade in moose skins, 27

Decatur, S., moose antlers, 187

Deer, see Virginia deer

Demidoff, Prince E., 339; hunting in Russia, 296

Denys, Nicolas, 122 (note); Indian kettles, 9-IO; slaughter of moose in Acadia, 26-27; Indian superstitions, 266, 267

"Depth of body" defined, 64

Description of moose, 64 et seq.; Sir Ferdinando Gorges, I I-12; William Wood, 13; Thomas Morton, 14; Montanus, 20-2I ; Josselyn, 2I-23; Judge Dudley, 23-25; of elk-Cæsar, 274; Pliny, 275; Münster, 278

Deterioration in antlers, 169-170, $360,382:: 334-335$

Development of antlers, I70I 7 I ::339-34I

Dewclaw bones as paper cutters, 200

De Weese, Dall. 60; large moose killed by, 67

Diéreville, the epilepsy superstition, 267 (note)

Digestibility of various foods, 205

Dimock, J. A., picture of calf moose, 84

Diseases of moose, 72, 73, 374-375 :: 305-307

Division into species, 56-62

Dogs in hunting, I45::318-322, 326 ; used by Indians, 9, 134I35, 138 ; in Cape Breton, 145

Dog-Rib Indian myth, 257-260

Domestication of moose, $17,71-$ 75; proposed, 12, 13, 14, 17; of elk, 307-3I5

Donne, Capt. T. E., on moose in New Zealand, 367-369

Douglas-Lithgow, Dr., quoted, 54 Dried moose meat, 16, I8

Driving game, by Indians, II, I34-I36; methods employed, 147. Elk drives in Europe, see Elk
Driving moose in harness, $74-75$, 376-377 :: 307-309

Dudley, Judge Paul, 35, 262; description of moose, 23-25; moose's muffle, 213

Earliest use of the word moose, I2

"East American moose," 372

East Prussia, elk in, 281, 284, 290, $293-295,306,378,384-385$

"East Siberian elk," 345 (note)

Eaton, A. W., quoted, 247-248

Edward VII., a New Brunswick moose head, 188; elk drive in Sweden, 327

Elend, origin of name, 239-24I

Elk, American, see Wapiti

Elk, European and AsiaticAntlers, 334-345; growth of, 312; slow development, 339$34 \mathrm{I}$; in captivity, 314 ; time of casting, 34I-342 ; fossil, 336337, 385: best specimens, 337339; Alces bedfordia, 343-345; used in medicine, $35 \mathrm{I}$

Hunting methods - with dogs, 318-322, 326; driving, 293294, 322-327; " circling," 325; calling, 327-330; pitfalls, etc., 330-333

Age, 301-302; diseases, 305307; domestication, 307-3I5; food of, 303, 3IO-3II; in herds, 302; identical with moose, 57 , $58,62,243,273$; insect pests, 306-307; migrations, 304-305; misbeliefs, $346-355$; not monogamous, 303; number, $29 \mathrm{I}-$ 292,293 ; playfulness, 310,312 ; elk products in the arts, 284287; in medicine, 346-351; range, 288-290; rutting season, 302 ; size, 281-282, 300 ; fondness for water, 303

Elk, Irish, 243-244

Elk, origin of the name, 239-240 Elwes, H. J., 338; on area required by moose, $377-378$; mountain ash in antler-building, $38 \mathrm{I}-382$

Embroidery in moose hair, 68

England, fossil remains in, $385^{-}$ 386

Epilepsy in moose, superstitious belief, 263-267::346-35 I 
Ermine, attacks on elk, 354

Exaggeration in respect to size, 2 I-22, 24, 64, 8I (note):: 280 353 ; in respect to antlers, $2 \mathrm{r}$, 26,176

Extermination of moose, no danger of, 32, 226-227, 36r -365

Eyesight of moose, inferior to that of man, 90-93

Fat of the moose, 207; prized by Indians, 18

Fay, S. P., moose antlers, 182

Feeding ground required by moose, $377-378$

Ferguson, L. G., Nova Scotia moose antlers, 189,360

Ferguson, W. P. F., moose on Isle Royale, 366-367

Field Museum, Chicago, moose antlers, 178

Fights between moose, 81,83 , 125, I 72, 173, $175: 328-329$

Finland, elk in, 288, 290, $291-$ 292,385

Firearms, I 52- I60, 380-38I

"Flat-horned elk," 243

Fog siren as a moose call, I 24 (note)

Food, moose meat as, 204-219; easily digested, 205; baked muffle, 216-218; broiling, 208; chafing dish, 210; chops, 209; cold storage, 206-207; corned, 218 ; the fat, 207; feet, 212; liver, 210; marrow, 2 I I ; muffle, 212-218; pan broiling, 208; roast, 209; smoked, 18; steaks, 208; stewing, 209; stewed muffle, 2 I 6 ; tongue, 2 I I

Food of moose, 86-87, 361, 382$383:: 303,310-3 I I$; effect of, on growth of antlers, $174,38 \mathrm{I}-38.3$; causes of improved food conditions, 361

Footwear, 16r-162

Forest conservation, 220 et seq. $361-365$

Forest fires, cause of improved food conditions, 36 I

Fortymile District, Alaska, number of moose, 43

Fossil elk antlers, 272, 336-337, 385-386
Fossil remains of moose, $4,372:$ : 272

France, extinction of elk in, 276

Fraser, Rev. J., on moose muffle, 214

Friese, Richard, painting of Russian elk, 27I

Future of the moose, 220-231, $36 r-365$

Gait of the moose, 74

Game as a national asset, 222-223, 225-226

"Game in New Netherland," 20

Game laws, 4I-52, 227-23I::296298

Game refuges, 36r -365

Gander Bay, Newfoundland, moose released, 370

Gander River, moose killed on, 370

Gannett, Henry, quoted, 272

Ganong, Prof. W. F., story of the racing moose, 376-377; the food factor in antler-building, 383

Gaspé Peninsula, 25, 31, 40; game preserve, 362, 364

Geographic names derived from moose, 53-56::292

Germany, gradual extinction of elk in, 276, 281

Gesner, Conrad, epilepsy in elk, 347

Giant moose, Indian belief in, 260-26I

Gibb, L. M., moose antlers, 186, 358-359

Glacier National Park, 362; moose in, 37

Glooskap in Indian myth, 247

Gorges, Sir Ferdinando, describes the moose, I I-12

Grand Lake, Newfoundland, moose released, 370

Grant, Madison, 33, 34, 96, 26I ; range of moose, 39 (note); brow palmation of Alaska antlers, 6 I

"Gray moose," 24, 372

Great Bear and Great Slave Lakes, moose at, 48

Greek name for elk, 239-240

Growth of antlers, 170-174, 360:: $312,339-341$; the food factor in promoting growth, $381-383$ 
Hair of moose, 68, $172::$ 286; used in Indian embroidery, 202-203; grows upward from the nose, 201

Hampton Court Palace, moose antlers in, $166-169$

Hardiness of moose, 223, 226, 367369

Hardy, Campbell, snaring moose in Nova Scotia, I37 (note); cooking marrow, 211 ; an Indian myth, 249

Harness, moose driven in, 74-75, 376-377::307-309

Head, Gov., his racing moose, 376-377

Hearing, sense of, in moose, 93

Height of moose, $64-67:: 300$

Heraldic moose of Michigan, 29

Herding of elk, 302

Hesketh-Prichard, 290, 298; jacking, I 47 ; hunting with dog, 319 ; Norwegian elk heads, 338

Hewitt, Dr. C. Gordon, quoted, 364 ; on moose parasites, $374^{-}$ 375

Hibbs, N., moose muffle baked in the ground, 216-2I7

Hide of moose as leather, I4, I5, $28,201:: 284-286$; Indian uses for, 202-203

Hinman, Maj. C. W., capture of calf moose, $85-86$

Hock, skin used for moccasins, 202

Hoffman, Dr. W. J., Indian myths, 255-257

Hollister, Dr. H., quoted, 372

Hoodoo State Game Preserve, Wyoming, 362

Hoofs, as weapons, 8I, I38:: 31 I$3 \mathrm{I} 2$; used in cure of epilepsy, $263-267:: 346-35$ I

Horn used in calling, 128

Hornaday, W. T., 67, 7o, 244, 339; specific differences in moose, 59 (note); size of antlers influenced by food, 6I (note); comparison of antlers, I9I (note); commercial value of venison, 222-223

Horse, size eompared with moose, 66; speed compared with moose, $74,376-377:: 309$

Howley, J. P., moose secured for Newfoundland, 370

Hudson Bay, 38, 53, 362
Human scent in tracks, 108

Hungarian method of mounting antlers, 166

Hunting methods now obsolete, 132-1 47

Huron Indians, moose-hair embroidery, 68; moose drives, I 35

Ibenhorst elk preserve, 284, 293, 301

Ice avoided by moose, 76

Idaho, moose in, $32,37,81$

Inbreeding, danger of, $37 \mathbf{I}$

Increase in number of moose, 32 , $38,39,42-44,46,49,5 \mathrm{I}, 36 \mathrm{I}-$ 366

Indians, their bows and spears, IO, II ; moose calling by, I22 (note); calling in British Columbia, I30; cooking methods, 8-9, 17-18; crust hunting, 6,8 , I37-I 40; driving moose, I34136; moose-hair embroidery, 68; feasts, 9, I7-I8; moose meat as food $6,8,15^{-16}, 27^{-}$ 29, I40; killing for market, I617, 27; myths regarding moose, 245-26I; names for the moose, 237; names of Indian origin, 54; moose products, 202-203; destruction of moose by, 27, 28, 30, 45-46, 98 (note), I 40; snaring moose, I36; superstitious beliefs, 262-268; tongue of moose highly prized, I 8, 2 I I

Indifference of moose to danger, occasional, 93-97, I O4-IO5

Insects which attack moose, 374$375:: 306-307$

Instinct of the moose, 69,100

Intelligence of moose, $67,69-7 \mathrm{I}$ Irish elk, 243-244

Isle Royale, moose on, 36, 365-367

Jacking, forbidden by law, I45; misconceptions concerning, I $45^{-}$ I 47; by automobile headlight, 379; fire hunting in Siberia, 332 Jackson Hole, moose to be sent to South Dakota, 372

James Bay, moose near, 362

Jasper Park, Alberta, 362

"Jesuit Relations," I5-I8, 25I (note), 261, 263 
Josselyn, Dr. John, 21 I, 262-263; description of moose, 2 I-23

"Jumping deer," 239

Kaiser, as an elk hunter, 293295

Kapherr, Baron von, 241, 261, 298; European elk identical with moose, $5^{8}$; diseases of elk, 305-306; riding on elk's back, 3 It (note); Russian hunting methods, 322-326, 327-328; il-: legal methods, $33 \mathrm{I}-332$

Katahdin National Park, proposed, 365

Kenai Peninsula, 38, 41-43, 53, $60,64,94,96,171,317,371$; estimated number of moose, 43 ; antlers, 177-I 80; locked antlers, I75; causes of antler development, $382-383$; largest measured moose, 67

Kennedy, M. A., moose antlers, 185

Kettles, Indian method of making, 8-10

Kineo, Indian myth, 248

Knight, C. R., drawing of Irish elk, 244

Knight, J. A., on Nova Scotia moose antlers, 360

Koyukuk and Kuskokwim Rivers, Alaska, moose increasing, 44

Lackawanna Valley, moose in, 372

Ladue Creek, Alaska, number of moose, +4

Lahontan, Baron, Indian crust hunting, I $37-140$; antlers weighing 300 pounds, 176 ; the epilepsy superstition, 265

Lake Huron, moose at, 361

Lake Superior, 26, 36, 38, I 35, 250; increase in number of moose, 361: moose on Isle Royale, 365-367

Lantz, D. E., 225; food value of venison, 205

Lapland, elk in, 288

Largest measured moose, 67; antlers, $177:: 337,338$

Laurentides Park, Quebec, 362, $36+$

Laws affecting game propagation, 73. See Game laws
Leather of moose skin, $14,15,28$, 201, $203:: 28 t-286$

LeClercq, Fr., the epilepsy superstition, 267

Le Jeune, Fr., quoted, I 7, I 8, 262

Leland, C. G., Indian legends, 247,25 I (note)

Lescarbot, picture of moose, 7,8 ; Indian method of cooking, 8-9

Licenses to hunt, see Game laws

Linnaus, 62

Lithuania, name for elk, 24I; traffic in elk hoofs, $34^{8}, 35^{\circ}$

Little Southwest Miramichi River, N. B., 365

Liver of moose, 2 IO-2 I I

Livonia, 292, 306, 309, 340, $3+2$

Lloyd, L., I75, 296, 327; elk calling by violin, 329 ; illegal hunting devices, 332-333

Locked antlers of moose, 175

Logging camps for hunting, 2,32

London, fossil antlers found near, 385

Lönnberg, Prof. E., quoted, 384

I.ydekker, R., moose and European elk identical, 57 ; origin of name elk, 239; Alces bedfordioe, 343-345

Mackay, C. H., moose antlers, 179

Mackenzie River, 39, 48, 80, 202, 258: valley occupied by moose, 362

Magnus, Olaus, elk as draft animals, 308-309; elk hoofs in medicine, 347 ; the ermine fable, 354

Maine, 6, 12, 21, 28, 30, 53, 55, $71.74,96,142$; moose in, 32; number of moose killed, 46; game law, 52 ; increase in number of moose, 32, 46; antlers, I 86-187, I 89; deterioration in antlers, I70; crust hunting in, I 1 I ; hunting from motor vehicle, 379, 380; Katahdin Nationa! Park, proposed, 365

Malignant anthrax, $73:: 305$

Mammoth and the moose, 260$26 \mathrm{I}, 272$

Manitoba, 35, 54, 55, 239, 345, 378,386 ; game law, 52 ; number of moose killed, 46-47; white clothing for hunters, 47 ; ant- 
lers, I 83 ; big-game refuges, 362 ; moose attacked by parasites, 374-375

Marrow as food, 2 I I

Martenson, A., 309, 323 (note); European elk identical with moose, 58 ; elk range, 290 (note); number of elk in Europe and Asia, 291-292; decrease in sone parts of Russia, 297, 330; age of elk, 30I; elk migrations, 304; insect pests, 306-307; elk calling in Russia, 328; crust hunting in Russia; 331 : antlers, 334, 335, 340-343; Alces bedfordio, 344345 ; yearly kill of elk in Russia, $3^{85}$

Massachusetts, I 3, 23, 35

McCutcheon, R. R., moose antlers, 182

Measurement of moose, 64-67; of antlers, I90-I94, 358-359

Menomini Indian myths, 255257

Merriam, Dr. C. H., quoted, 34

Michigan, moose in, 36, 365-367; in 1834,29

Micmac myths, 249-25I

Migration of moose, 3, 39-40, 42 :: 289, 304-305

Millais, J. G., European elk antlers, 339; British Columbia antlers, 357 ; Alberta antlers, $35^{8}$

Miller, G. S., Jr., characteristics of Alces gigas, 59-60

Milzbrand, $73:: 305$

Minchumina Lake, Alaska, moose at, 43

Minnesota, 53, 55, 363, 378; moose in, 36-37; number of moose killed, 37, 47; game law, 52; antlers, 184; Superior State Game Refuge, 362, 363; hunting from motor vehicle, 380

Moccasins of moose skin, I5, 20I, 203; moose-hock, 202

Monogamy not practised by moose, $82:: 303$

Montagnais Fish and Game Club, 358

Montana, 53; moose in, 37; Glacier National Park, 362

Montanus, Arnoldus, quoted, I9

Moonlight, important in calling, 128
"Moose," earliest use of word, I2; origin of the name, 237

Moose birds, 306

"Moose in Politics," 234

Moose meat as food, see Food

Moosehorn napkin ring, I99

Mooselucmaguntic, 54

Moosewood, 87

Moosic, Moosup, origin of names, 373

Morton, Thomas, describes the moose, 14

Motor vehicles in hunting, 380

Mountain ash in antler-building, $38 \mathrm{I}-3^{8} 3$

Mountain sheep, I 80,363

Mount Desert Island, I2, 55, 248

Mount McKinley National Park, Alaska, 362, 363

Mount Olympus, Wash., 371

Mount Robson National Park, B. C., 362

Mounting game heads, I94-I98

Muffle of moose, 212-2 I8; stewed muffle, 2 I6; baked muffle, 2 I6218

Munro, Dr. W. L., moose antlers, I 87

Münster, description of elk, 278 , 3 I 4 (note)

Myths concerning the moose, 245-26I

Names of the moose, errors respecting, 237,243

Napkin rings of moose horn, I98

National Collection of Heads and Horns, I 75, I79 (note)

Nenana River, Alaska, moose at, 43

Nepisiguit River, N. B., antlers, I87, 359; game refuge, 364-365

New Brunswick, 54, 67, 75, 98, I65, I 75, I99, 248, 370, 380, 381 ; moose in, 32; game law, 52 ; number of moose killed, 48 ; increase in number of moose, 32,362 ; size of moose, 60,67 (note); antlers, I87-I 89, 359360; Provincial game refuge, 362,364 ; story of racing moose, $376-377$

Newfoundland, I55, 369; attempt to stock with moose, 38 (note), 
$370-37 \mathrm{I}$; danger of inbreeding, $37 \mathrm{I}$

New Hampshire, 54, 55; last moose in, 33

"New Netherland, Game in," 19-2I

New York, 19-20, 33-35, 53, 54, $55,37 \mathrm{I}$

New Zealand, 382 ; moose released in, $367-369$

Newton, E. T., fossil antlers in Thames valley, $385-386$

Niedieck. P., moose antlers, I80; an adventure on Kenai Peninsula, 96

Night, moose active at, 89

Night hunting, I45-147, $379:: 332$

Northern boundary of moose's range, $38-.39:: 288-289$

Northwest Territories, 55, 80, 202; moose in, 48; game law, 52 ; increase in number of moose, 39,362

Norway, 316, 317, 377, 378; Pontoppidan's description of elk, 280; elk in, 290, 291, 296; hunting regulations, 296, 298; elk in harness, 308; hunting with dog, 319; antlers, 338, 382; large antlers of Trondhjem, $38 \mathrm{I}-382$; elk kill in war-time, 384 . See Scandinavia

Nova Scotia, 7-8, 54, 55, 85, 90, I04, I28, I65, 21 8, 248, 370; moose in, 32 ; game law, 52 ; protection of cow moose, 228-229; number of moose killed, 49; increase in number of moose, 49; moose rarely yard, 98 ; antlers, I 89,360 ; wild land in, 221 ; removal of meat from the woods 23o; Micmac myths, 249-25I; game refuges proposed, 365

Number of elk-East Prussia, 293; Russia, 292; Scandinavia, 29I. Increase in number, 289; East Prussia, 293; Finland, 29I-292; Norway, 290-29I. Decrease, Russia, 297, 330

Number of moose, estimated-in America, 40; Alaska, 43-44; Yellowstone Park, 38, 5I, 363; Wyoming, 5I; Minnesota, 37, 364; Ontario, 364; Saskatchewan, 50. Increase in number,
36I-365; Maine, 32, 46; Michigan, 365-366; Yellowstone Park, $38,5 \mathrm{I}, 363$; Wyoming, 5I ; Alaska, 39, 42-44, 362; New Brunswick, 32, 362; Nova Scotia, 49; Ontario, 36r ; British Columbia, 362; Yukon, 362; Northwest Territories, 39, 362

Nuremberg, elk antlers in, 276

October Mountain preserve, 35-36

Oken, Lorenz, quoted, 305, 354

Old moose, antlers of, I 74 (illustration), $360:: 3+$ I

Olympic National Forest, $37 \mathrm{I}-372$

Onager, a name for elk, 242, 280

Ontario, 30, 53, 54, 55, 66, 239 , 378; hunting in, 49; game law, 52: antlers, I 84-186; increase in number of moose, $36 \mathrm{I}$; biggame refuges, $362-364$

Orenac, Basque name for moose, 238

Orignac, orignal, origin of name, 238

Osborn, Prof. H. F., quoted, 3, 4, 244

Osborn, J. B., moose antlers, 193

Osgood, $W$. H. quoted, I 2 I

Ottawa River, I 40 (note), 2 I4

Over-stocking, effect of, 378,382

Palmation, measurement, I9 I

Pan broiling, 208

Paper cutters of dewclaw bones, 200

Parasites which attack moose, 374-375::305-307

Passamaquoddy myth concerning creation, 247

Patapedia Lakes, Quebec, antlers, $35^{8}$

Pausanius, mentions the elk, 240

Peace River, large antlers, $35^{8}$

Peeling bark, 87, 107

Pennsylvania, fossil remains of moose, 372; moose in historic times, $372-373$

Penobscot belief concerning origin of moose, 249

Percival, H. C., moose antlers, I 84

Perrot, Nicolas, moose driving by dogs, I 35

Photographing game, I $45^{-I}+6$ 
Pictou, Joseph, Nova Scotia moose antlers, 360

Pike, Warburton, quoted, 357

Pitfalls, used by Indians, II; in Europe, 330, 332

Place names derived from moose, $53-55,372-373$

Playfulness of elk, 3 IO , 3 I 2

Pliny, his name for elk, 24I ; description, 275

Poachers, 364 :: 297-298, 33I-333, 384

Poland, fossil elk antlers, 336; extinction of elk in, 285

Pomet, Pierre, elk hoofs in medicine, 349-350

Pontoppidan, description of elk, 280

Pottinger, Sir Henry, 160, 320, 327 ; increase of elk in Norway, 290-29I; size of elk, 300

Pounding on a tree in calling, 130

Prehistoric hunters, I 32

Preserves of moose, private, 35 , $36,72-73$; public, $37,38,36 \mathrm{I}^{-}$ 366,372

Prichard, see Hesketh- Prichard

Prince Edward Island, 27, 25I, (note)

Prongs, how counted, 190, 19I

Propagation of moose, $72-73,361-$ 365

Protective legislation, 4I, 52, 22723I, 36I-365

Purchas, "Pilgrimes," quoted, I I12

Quebec, 54, 78, 237; moose in, 39; hunting in, 50, game law, 52; antlers, 186, 358; big-game refuges, 362,364

Quetico Provincial Reserve, Ontario, $362-364,378,382$

Racing moose, 376-377

Rarlclyffe, Capt., ${ }_{178}$ (note); stalking moose, 316-317

Radisson, moose hunting, 26

Rand, Rev. S. T., an Indian myth, 250-25I

Range of moose, 32-52, 226, 367 ::288-290; Montanus quoted, 20-2 I ; Judge Dudley, 24; Champlain, 25; Sagard-Theodat, 25;
Radisson, 26; Denys, 26-27; in Michigan, 29; in Newfoundland, $370-37 \mathrm{I}$; in New Zealand, 367-369

Rasle, Fr., slaughter of moose, 28; Abnaki dictionary, 237 (note), 265, 267, 268

Record spread, moose antlers, 177

"Red deer," in America, 239

Red deer (Cervis elaphus), I67, $170,195,237,239,342,382$

Reerl, A. S., moose antlers, 178 , I 82, 357

Reed-McMillan collection, 178

Refuges, for game, $36 \mathrm{I}-365$

Removal of meat from the woods, 229-231

Renous River, N. B., antlers illustrated, I4, 68, I 74

Restigouche River, N. B., antlers, 359

Restocking moose range, $37 \mathbf{I}-372$

Rhine, former home of elk, 276 , 337

Rhoads, S. N., quoted, 372

"Riding down" saplings, 87

Riding Mountains, Man., 375

Riding Mountain Preserve, 363

Riggs, Gov., estimates of moose in Alaska, 43-44

Rinderpest, $73:: 305$

Roast haunch of moose, 209

Rock carving of elk, 273

Rocky Mountains, 37, 54, 64, 8I (note), 180, 183, 217; an Indian myth, 257-260; antlers, 358

Rocky Mountain Park, Alberta, 362

Roosevelt, T., encounter with a vicious moose, 78-80

Ross, B. R., Indian uses for moose products, 202-203

Rungius, C., moose called by, I 2 I

Russell, Lazare, New Brunswick moose antlers, 359

Russia, elk in, 288-290: number, 292 , 297, 330; hunting regulations, 296-298; stalking, 318; hunting with $\operatorname{dog}, 320-322$, 326; elk drives, 322-326; "circling," 325 ; calling, 327-329; pitfalls, 330; antlers, 334-335, 339, 344-345; elk in captivity, I4, 309-315; tribute paid in elk skins, 285; elk migrations, 
304-305; weight of elk, 300; yearly kill of elk, 385 ; elk in war-time, 384-385

Rutting season, $8 \mathbf{I}-83:: 302$; growth of antlers associated with, $81,172,173$

Saddle, objection of elk to, $3 \mathbf{I} 4$ (note)

Saguenay River, 9, I6-I 7

St. Croix River, moose hunting on, 6

St. John River, moose driven on ice, $75,376-377$

St. Lawrence River, 5, 6, 28, 3031, 137

Sale of game, $48,73,228$

Saskatchewan, 39, 54, 55; game law, 52; number of moose killed, 50; white clothing for hunters, 47 ; antlers, 358 ; biggame refuges, $362 ;$ moose taken to New Zealand, 368; moose attacked by parasites, $374-375$

Scandinavia, 332, 339; boundaries of elk range, 288-290; number of elk in, 291; size of elk, 300, 382; antlers, 334-335. 344,382 ; elk killed in war-time, $384-385$

Scent of moose, 93

Schoolcraft, 29; Indian myths, 250

Scientific names for the moose, $56-62,236-243$

Scotland, fossil remains in, 386

Scott, Prof. W. B., quoted, 4

Seasons for moose hunting, 4I, 52 :: 296; for calling, 120,122

Selous, F. C., 65 (note), I22; adventure with a sleeping moose, 95; moose antlers, I 82

Seton, E. T., I 84 (note), 345,386 ; number of moose in America, 40; area required by moose, 378

Seymour, Gov. Horatio, 33

Shaw, Otho, moose antlers, I 84 (note)

Shedding antlers, time of, I 7 I :: $34 \mathrm{I}-342$

Shiras, Hon. George, 3d, 60 (note), 378; moose on Yellowstone River, 38; adventure with cow moose, 94-95; jacking, I46; cast antlers found, I $7 \mathbf{I}$; moose of Yellowstone Park, I 72 (note); on increase in number of moose, $361-362$; causes of antler development on the Kenai, 382383

Shiras, moose, 60 (note)

Shoemaker, H. W., quoted, 373

Shoepacks, in hunting, I 62

Shoshone State Game Preserve, Wyoming, 362

Shoulder blade of moose, used in calling, 131

Siberia, 320; ancient home of moose, 271, 343-344; elk in, 288 ; elk migrations, 304 ; peasants' hunting methods, $330-332$; antlers, 334-336, 343-344

Sight, sense of, in moose, 90

Sinews, Indian uses for, 202-203

Size of moose, $60,64-67:: 281-$ 282,300 ; signs indicating size, I08; compared with Irish elk, 244

Skins of elk, formerly considered bullet-proof, 284

Skins of moose in trade, 16-17, 27, $30:: 292$; as leather, $14^{-1} 5,28$, 2C 1, $203:: 284-286$

Skrowronnek, Dr. F., elk in East Prussia, 293-294; elk as swimmers, 303

Skull of moose, 88

Sledge drawn by elk, 308

Sleeping moose, Selous' adventure with, 95

Small-bore rifles, I 53

Smell, sense of, in moose, 93

Smoked moose meat, 16,18

Snares, used by Indians, I I, I36; in Nova Scotia, 137 (note); in Siberia, 330

Snowshoes, ancient, I38-r 40

South Dakota, introduction of moose in, 372

Southern hemisphere, moose in, $367-369$

"Speaking bull," I $26:: 327-329$

Species of moose, $56-62$

"Spitzer" bullet in hunting, I 56, 380-38 I

Spread of antlers, I90, I9I; not the only test of quality, 193

Springfield rifle in hunting, $380-$ 381

Stalking, see Still-hunting

Steak, broiling, 208 
Stella, Erasmus, quoted, 20, 355

Stewing moose, 209; stewed muffie, 216

Still-hunting, 99-119, 316-318: compared with calling, IOo; need of vigilance, 101; windy day favorable, I05; special caution at midday, 106; tracks, I06; browsing and peeling, I07; hunting in pairs, 107; the human scent in tracks, 108; signs indicating size, 108; teeth marks on trees, 109; indications of sex, IIO; hunting against the wind, IIO; hunting with the wind, I12; hunting out a yard, II4; importance of seeing the head, II 5; possible mistakes, I 16; be sure your moose is dead, I 8 ; when walking is noisy, I48 Stone, A. J., 81, 96, I I 8, I2I, I3I, 226; moose not in danger of extermination, 32 ; measurement of Alaska moose, 64

Stuck, Dr., quoted, 56, 221 (note)

Superior National Forest and State Game Refuge, 37, 362, $363,378,382$

Sweden, elk in, 290, 291, 295-296; elk in harness, 307-309; hunting with dog, 320; elk drives, 326-327; calling by violin, 329; antlers, 337, 339; elk kill in war-time, 384. See Scandinavia

Swimming by moose, $75:: 303$

Switzerland, elk in, 276

Tail of moose, 69

Taming moose, $7 \mathrm{I}$

Tanana River, Alaska, 42, 363; moose increasing, 44

Tannin in food of moose, 72

Tanning moose skins, 201

Tansy, elk fond of, 310

Taxidermy, 194-198

Teeth of the moose, 88-89, 109

Temagami Forest Reserve, I 85

Teton State Game Preserve, Wyoming, 362

Thames valley, fossil antlers, $385^{-}$ 386

Thompson-Seton, See Seton

Thoreau, 164, 246; Indian myths, 249
Ticks which infest moose, $374-375$ $:: 306-307$

Timber not destroyed by moose, 224,365

Timber line, I80; boundary of moose range, $38:: 288$

Tobique River, N. B., I 87, 365

Tongue of moose, I 8,2 I I

Topham, Anne, the Kaiser's elk hunt, 294-295

Tracking moose, 106

Trade in moose skins, $16-17,27$, $30:: 292$

Traits and habits of moose, $63-98$ $:: 300-315$

Trondhjem, Norway, 290, 384; large antlers secured, $381-382$

Tropics, journey of moose through, 368-369

Ural Mountains, 288, 289, 304, $33 \mathrm{I}$

Utilization of meat required by law, 230

Van Dyke, T. S., quoted, I59

Velvet on antlers, I 72, 360

Venison, includes moose meat, 204; especially adapted for invalids, 205; its commercial importance, 222-223, 225-226

Vermont, 54, 55; last moose in, 33 , 373-374

Vienna, International Sportsmen's Exhibition, I70, I 79, 337

Violin as an elk call, 329

Virginia deer, 28, 33, 46, 67, 69, $70,72,74,76,80,84,115,224$, 369; migration from Asia, 4; first met by colonists, 237

Vitality of wounded moose, I I 8I I 9,160

"Walking down" a moose, 142

Wallow, 83

Wapiti, 24, 30, 46, 67, 72, 140, 223, $239,369,371,372,382$; migration from Asia, 4; misnamed the elk, 237

Ward, Rowland, Records of Big Game, 180, 184, 186, 187::338, 339, 345 (note); Irish elk, 244

War-time influences in the elk range, $284,384-385$ 
Washington, State of, stocking with moose, $371-372$

Wasteful killing of moose, 25-31, $42-43,229$

Water, moose fond of, $75:: 303$

Waterton Lakes Park, Alberta, 362

Weight of moose, 66-67::281282, 300; of antlers, 176, 178, 180, I8I (note), I 88, I91, 358

West Prussia, extinction of elk in, 281

Whitaker, J. R., on moose in Newfoundland, $37 \mathrm{I}$

White clothing for hunters, 47 , 14 I

Whitetail, see Virginia deer

Whitney, Hon. Wm. C., moose in preserve, 35

Wind, in still-hunting, 105, 110I 4

Wisconsin, 55; moose in, 36; Menomini Indian myths, 255257

Wolves, 13, 42, 44, 136, 181 (note), 296

Wood, William, 136; verses on New England fauna, 12-13; describes the moose, 13
Worm, Olaus, misbeliefs about the elk, 353

Wounded moose, danger from, 76 , 80; vitality of, II8-119, I60; the "Dawkins trick," I 43

Wyoming, 176, 223; moose in, 32 , 37; game law, 51-52; number of moose increasing, 5I; Alces americanus shirasi, 60 (note); State game preserves, 362 ; moose sent to South $\mathrm{Da}$ kota, 372

Wysotzki, K., "An Elk Drive," 271

Yards, 97-98, II 4, 37 I

Yellowstone Park, 60 (note), 172 (note); increase in number of moose, 38, 51, 363

Yentna River, Alaska, moose at, 43

Yukon, $54,55,65,95,98,122$; game law, 52 ; number of moose killed, 52; utilization of meat required, 230; antlers, 180-182; increase in number of moose, 362

Yulson River, 42, 44, 54, 258-260 


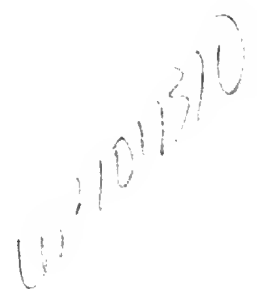





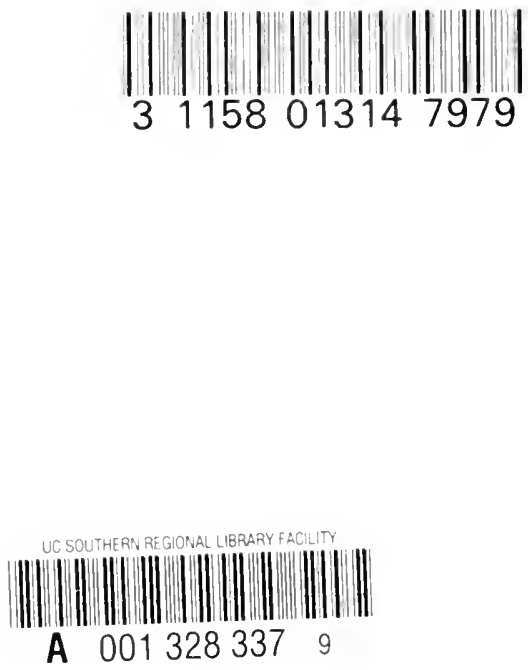
W

2. 3 (1)

I.

3.

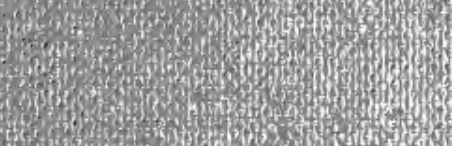

(6) 200 (2) (3)

36)

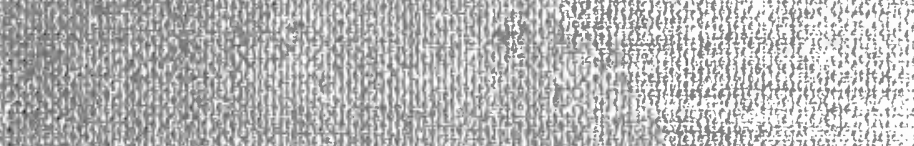

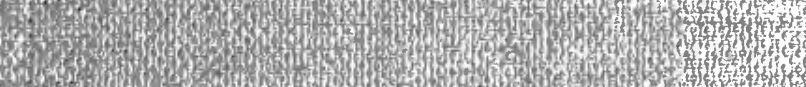

3.

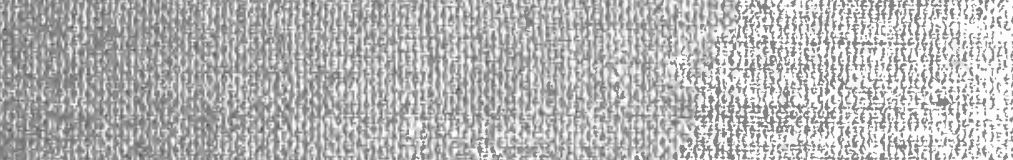

300 -

3.

19.

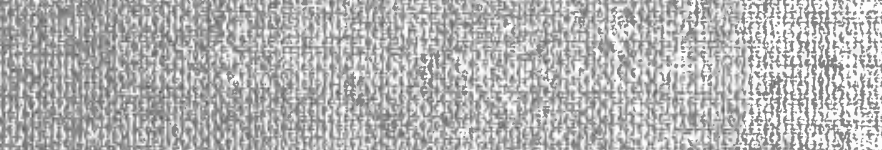

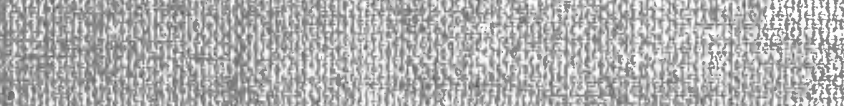
$4 b^{2}$ intions 4)

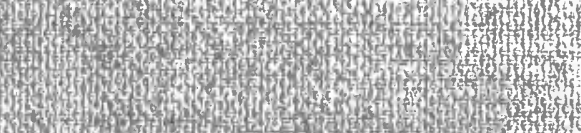

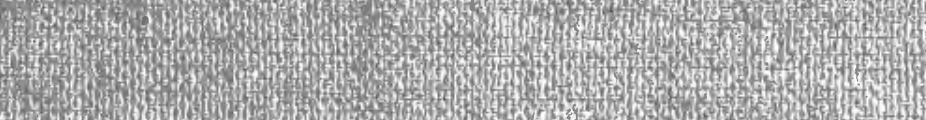

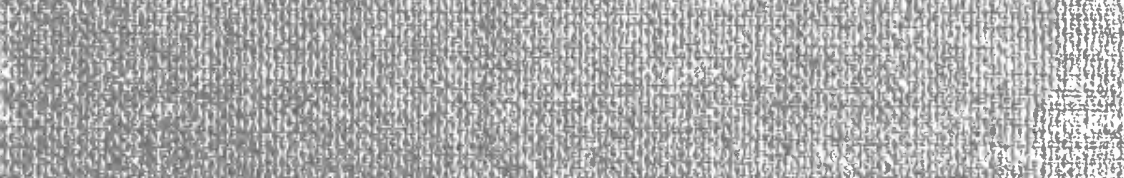
\begin{tabular}{l}
5 \\
\hline 5
\end{tabular}

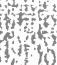
int (⿻) in? ivity

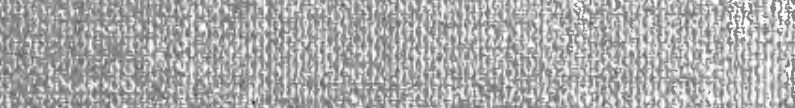
(1) 4 teteld 2. 